DANILO CICCONE MIGUEL

\title{
CARACTERIZAÇÃO DA ATIVIDADE DE TAMOXIFENO NO TRATAMENTO DA LEISHMANIOSE EXPERIMENTAL E INVESTIGAÇÃO SOBRE SEUS MECANISMOS DE AÇÃO
}

Tese apresentada ao Departamento de Parasitologia do Instituto de Ciências Biomédicas da Universidade de São Paulo, para obtenção do Título de Doutor em Ciências. 


\section{DANILO CICCONE MIGUEL}

\section{CARACTERIZAÇÃO DA ATIVIDADE DE TAMOXIFENO NO TRATAMENTO DA LEISHMANIOSE EXPERIMENTAL E INVESTIGAÇÃO SOBRE SEUS MECANISMOS DE AÇÃO}

Tese apresentada ao Departamento de Parasitologia do Instituto de Ciências Biomédicas da Universidade de São Paulo, para obtenção do Título de Doutor em Ciências.

Área de concentração:

Biologia da Relação Patógeno-Hospedeiro

Orientadora:

Profa. Dra. Silvia Reni Bortolin Uliana 
DADOS DE CATALOGAÇÃO NA PUBLICAÇÃO (CIP)

Serviço de Biblioteca e Informação Biomédica do

Instituto de Ciências Biomédicas da Universidade de São Paulo

reprodução não autorizada pelo autor

Miguel, Danilo Ciccone.

Caracterização da atividade de tamoxifeno no tratamento da leishmaniose experimental e investigação sobre seus mecanismos de ação / Danilo Ciccone Miguel. -- São Paulo, 2011.

Orientador: Silvia Reni Bortolin Uliana.

Tese (Doutorado) - Universidade de São Paulo. Instituto de Ciências Biomédicas. Departamento de Parasitologia. Área de concentração: Biologia da Relação Patógeno-Hospedeiro. Linha de pesquisa: Bioquímica e biologia molecular de Leishmania.

Versão do título para o inglês: Activity of tamoxifen in the treatment of experimental leishmaniasis and investigation on its mechanisms of action.

Descritores: 1. Leishmania $\quad$ 2. Leishmaniose 3 3. Quimioterapia 4. Infecção experimental 5. Tamoxifeno 6. Esfingolipídios I. Uliana, Silvia Reni Bortolin II. Universidade de São Paulo. Instituto de Ciências Biomédicas. Programa de Pós-Graduação em Biologia da Relação Patógeno-Hospedeiro III. Título. 
Candidato(a):

Título da Tese:

Orientador(a):
Danilo Ciccone Miguel.

Caracterização da atividade de tamoxifeno no tratamento da leishmaniose experimental e investigação sobre seus mecanismos de ação.

A Comissão Julgadora dos trabalhos de Defesa da Tese de Doutorado, em sessão pública realizada a

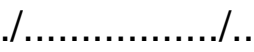
, considerou

\section{( ) Aprovado(a) \\ ( ) Reprovado(a)}

$\begin{array}{ll}\text { Examinador(a): } & \text { Assinatura: } \\ & \text { Nome: ....... } \\ & \text { Instituição: } \\ \text { Examinador(a): } & \text { Assinatura: } \\ & \text { Nome: ....... } \\ & \text { Instituição: } \\ \text { Examinador(a): } & \text { Assinatura: } \\ & \text { Nome: ........ } \\ & \text { Instituição: } \\ \text { Examinador(a): } & \text { Assinatura: } \\ & \text { Nome: ........ } \\ & \text { Instituição: } \\ & \text { Assinatura: } \\ \text { Presidente: } & \text { Nome: ......... } \\ & \text { Instituição: }\end{array}$




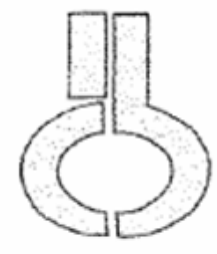

\section{Certificado}

Certificamos que o protocolo registrado sob $\mathrm{n}^{\circ} \mathbf{1 5 7}$ nas fls. 24 do livro 2 para uso de animais em experimentação, sob a responsabilidade do(a) Prof.(a) Dr.(a) Silvia Reni Bortolin Uliana, Coordenador(a) da Linha de Pesquisa "Investagação de mecanismos de ação do tamoxifeno em parasitas do gênero Leishmania e estudo de sua eficácia no tratamento de Leishmaniose experimental' do qual participou(aram) o(s) alunos: Danilo Ciccone Miguel, está de acordo com os Principios Éticos de Experimentaçāo Animal adotado pelo Colégio Brasileiro de Experimentação Animal (COBEA) e foi aprovado pela COMISSÃO DE ÉTICA EM EXPERIMENTAÇÃO ANIMAL (CEEA) em 23.02.2006.

São Paulo, 06 de março de 2006.

Profa. Dra. Marília C.L. Seelaender Coordenadora da CEEA - ICB/USP
Profa. Dra. Patricia Castelucci Secretária Suplente CEEA - ICB/USP 
Dedico esta Tese de Doutorado aos meus pais, Jorge e Pérola, por acreditarem em meus sonhos e aos meus irmãos, Bárbara e Jorge, meus eternos exemplos de caráter.

Dedico ainda este trabalho à minha esposa, Alessandra, por me mostrar dia após dia, de forma tão genuína, que o amor existe... De verdade. 


\section{AGRADECIMENTOS}

Primeiramente à Professora Silvia Uliana. Fica difícil resumir em um espaço tão pequeno o tamanho da minha gratidão e admiração por você, que me acolheu tão generosamente desde aquela época em que nem barba eu tinha... Agora se passaram 8 anos, ou melhor, passamos por 8 anos de aprendizado e de conquistas. Não serão os papers que ficarão como marca de toda essa história, mas sim, cada momento em que aprendi a pensar em cada resultado que te mostrava; a refletir em cada próximo passo a ser tomado; a criticar e saber ser criticado nos mais variados aspectos e, mais importante, a respeitar a ciência em sua magnitude. Serei eternamente grato por toda a sua dedicação como minha mentora nessa etapa da minha vida! Obrigado pela confiança constante e por oferecer à minha formação profissional (e pessoal!) a sua primorosa orientação!

Mais do que especiais à minha amiga do peito, madrinha de casamento, companheira de fluxo, "pau pra todo experimento" e confessora Jenicer (Jê, Jejis, Jejoca, Mutchas...)! Obrigado é pouco para você, Jê! Posso afirmar com toda a certeza do mundo que tenho muito orgulho de ter participado da sua vida ao longo desses anos todos... Não foi só de eppendorfs, leishmânias, memoriais e pipetas que nossa amizade foi feita, mas também de muito carinho, gargalhadas, piadas e até lágrimas, né? Nossa, vou mesmo sentir falta de chegar cedo no lab e te encontrar para atualizarmos as news... Obrigado mais uma vez pela paciência e prontidão nipônicas, por ser meu exemplo de zelo e respeito com o dinheiro público e por me apoiar, INDUBITAVELMENTE, em todos esses anos de convivência!

Também especialíssimos a quatro meninas que na verdade são mulheres profissionais e guerreiras: Camila Ramos, Denise Arruda, Rogéria Zauli e Sandra Kalil. A Denise foi minha primeira amiga no Departamento e, muito feliz, eu te agradeço por conservarmos essa amizade viva até hoje. Minha grande Mutchabilinha mais chatinha que me levou pro mundo das drogas (no bom sentido!) e com quem hoje tenho o prazer de discutir experimentos, filmes, música e outros tantos assuntos... Obrigado por estar sempre 
do meu lado! Você fez parte disso tudo também! Já a Camila, nossa eterna Puffinha, foi minha professora de BioMol no lab. Sempre foi minha referência de dedicação e seriedade, apesar de participar de várias palhaçadas comigo também... Puffs, obrigado por me ensinar tanta coisa, por me dar o prazer de ter sua amizade dentro e fora da ciência!!! Mais tarde veio a Rogerinha, nossa mineirinha tão sossegada com quem dei muitas risadas e por quem "não dei conta"... Rô, você será sempre minha querida professora, aluna, amiga de cerveja, de conversa, de discussão de resultado e de montar figuras (Ahhhh!!!)... Obrigado por ter feito nossos dias serem mais divertidos! Por último, mas não menos importante, vem a Sandrita: “Ô Kalil, chegou a hora de eu ir embora! Você vai sentir minha falta?"... Eu sentirei muito a sua, no café, nas minhas dúvidas rápidas de BioMol e principalmente nas nossas risadas de qualquer coisa! Agradeço do fundo do meu coração por todo o carinho que você me deu ao longo desse tempo que fomos companheiros na bancada ou longe dela! Sou grato também pela sua construção pXG1Luc usada na transfecção em L. amazonensis. MENINAS, MUITO OBRIGADO POR TUDO!!!

Aos colegas do laboratório: Cristiana, Vivian e Alessandro, por estarem sempre dispostos a ajudar e pela convivência ao longo destes anos todos.

Às duas "malas" que me perseguiam dia e noite pelos corredores do ICB: Magrela e Malona! Fabi e Tar, agradeço pela amizade, pelas conversas, brigas, almoços, discussões e desabafos. Sentirei falta das nossas saídas e risadas, do alto astral de vocês! Obrigado pela amizade, de verdade!!!

Ao Prof. Alejandro Katzin, por disponibilizar seu laboratório durante todos esses anos e pelos conselhos sempre vindos nas melhores horas. Obrigado especial a toda sua equipe que sempre colaborou comigo: Emilia, Valnice, Fabiana, Renata, Miriam, Heloisa, Rodrigo, Alexandre, Márcia...

À Profa. Tania Katzin, pela amizade, confiança e troca de informações preciosas sobre qualquer assunto, seja ele científico, político ou artístico... Grato por ceder seu laboratório 
em todos os momentos que precisei. Obrigado também pelas imagens de microscopia eletrônica. Aproveito aqui para agradecer ao Alexandre Moura que sempre se prontificou a me ajudar quando pedi!

Aos laboratórios das Profas. Marta Teixeira e Silvia Alfieri, cujos membros sempre foram muito receptivos. Um obrigado mais do que especial à Ana Cristina, Flávia, Zuleima, Omar, Charlotte e Herakles!

Ao laboratório do Prof. Ariel, em especial à Beth Pral, por estar sempre disposta a me ajudar e por sempre dar um jeitinho de subir pra nos visitar! Agradeço também à Lisvane Paes e Anahí Magdaleno por sanarem minhas dúvidas em muitos momentos.

À Marinete, pelo carinho e pelo trabalho constante. Obrigado pelo seu "Bom dia" sorridente toda manhã...

Ao Manuel, por me ensinar tudo o que sei no manuseio de camundongos! E pelos ótimos momentos no café!

Ao Laboratório do Prof. Gerhard, pelas análises em luminômetro de tubo e à Fernanda Cabral, pela amizade e alto astral contagiante!

À Fapesp, pelo apoio financeiro por meio da bolsa de doutorado e da reserva técnica, essa muito útil para a aquisição de reagentes e para participação em congressos. Agradeço também pelo apoio financeiro que permitiu que eu realizasse o doutorado-sanduíche no exterior pelo período de 3 meses.

À Profa. Norma Andrews por ter me recebido em seu laboratório durante o período de estágio nos Estados Unidos e aos dois amigos que lá fiz e que sei que serão para vida toda: Cecília Fernandes e Mauro Cortez. Obrigado pela ajuda na hora que mais precisei! 
Ao Prof. Renato Mortara e Valter Andreoli, pela disponibilidade para realização dos experimentos de microscopia confocal.

Aos Profs. Anita Straus, Marcos Toledo e Helio Takahashi, pelo apoio desde o início do projeto e pelos plantões de dúvidas sobre o misterioso mundo dos esfingolipídios.

Ao Prof. Marcello Barcinski e ao Mario Balanco, pelas sugestões importantes ao longo do projeto e por disponibilizar o fluorímetro para análise de nossas amostras.

À Profa. Clara Barbiéri e Simone Katz, pela colaboração nos experimentos de infecção de hamsters.

Ao Prof. Álvaro Romanha e sua equipe e à Profa. Ana Claudia Torrecilhas, pela colaboração nos experimentos com Trypanosoma cruzi.

À Profa. Maria Helena Carvalho, pelos ensinamentos e auxílio na produção dos lipossomos.

À Profa. Alicia Couto, por todas as conversas, e-mails e análises de espectrometria de massas. Agradeço à Tamara Piñero e Malena Landoni também pelo auxílio com as análises de nossos esfingolipídios.

Às Profas. Maria Julia Manso Alves, pelo auxílio na obtenção de imagens em microscópio de fluorescência e pelas conversas sempre muito enriquecedoras e cheias de ideias.

À Profa. Telma Zorn, pela análise dos úteros de camundongos infectados.

À Profa. Deborah Schechtman, Mariana e Eliciane, pelo auxílio tão prestimoso nos experimentos de bidimensional. Obrigado e muito, pela paciência! 
À Profa. Carla Columbano e alunos, pelas análises no leitor Storm.

Ao Prof. Carlos Taborda e sua equipe, por cederem espaço de seu laboratório e por estarem dispostos a esclarecer minhas dúvidas sobre os esfingolipídios.

Aos meus amigos: Renato, Marcitchas, Carla, Gabi e Tatiana. Obrigado meus amigoscientistas! Longe ou perto, eu sempre vou ser grato a vocês!

A todos os alunos que passaram pelo laboratório com quem aprendi muito: Deborah, Ana Maria, Rafael, Felipe e, em especial, à Lina Borda.

À minha esposa, Alessandra. Obrigado por estar do meu lado e por me apoiar com tanto amor ao longo desta trajetória.

À minha família: Mãe, Pai, Jorge, Bárbara, Rodrigo, Vó Pérola, Bete, Pedro, João, Carol e Rachel; obrigado especial à Rose, Adelmo, Júnior, André e Gabi; aos meus amigos campineiros (toda a galera da pesada!): agora vocês entendem o porquê de tanto estudo, né? Obrigado por torcerem por mim em todos os momentos... 
"A perplexidade diante da vida surge quando nos defrontamos com tantas coisas interessantes que fica difícil focar o interesse em uma delas" 


\section{RESUMO}

Miguel DC. Caracterização da atividade de tamoxifeno no tratamento da leishmaniose experimental e investigação sobre seus mecanismos de ação. [tese (Doutorado em Parasitologia)]. São Paulo: Instituto de Ciências Biomédicas da Universidade de São Paulo; 2011.

O tratamento de indivíduos que apresentam leishmaniose, seja ela cutânea ou visceral, é usualmente problemático, uma vez que os medicamentos utilizados na prática clínica são altamente tóxicos, requerem administração parenteral e nem sempre promovem a cura dos pacientes. Torna-se clara, portanto, a necessidade de se pesquisar novos fármacos com potencial leishmanicida. O objetivo da presente Tese de Doutorado foi caracterizar a atividade do tamoxifeno, composto utilizado no tratamento do câncer de mama há décadas, contra diferentes espécies de Leishmania in vitro e in vivo, além de identificar seu possível mecanismo de ação. As concentrações inibitórias de tamoxifeno para 50\% de culturas de parasitas tanto de cepas de laboratório como de isolados recentes de pacientes variaram de 5 a $20 \mu \mathrm{M}$. Além disso, nossos resultados mostraram que a aplicação intraperitoneal de 20 $\mathrm{mg} / \mathrm{kg} /$ dia de citrato de tamoxifeno por duas semanas levou à redução significativa no tamanho das lesões e das úlceras na base da cauda de camundongos BALB/c infectados com L. (L.) amazonensis, bem como à diminuição da carga parasitária. Diferentes modelos de infecção animal comprovaram ainda a eficácia de tamoxifeno contra L. (L.) chagasi e $L$ (V.) braziliensis. Apesar da atividade deste fármaco estar diretamente relacionada à inibição da ligação de estrógeno ao seu receptor, ele exibe efeitos moduladores da atividade de proteínas sinalizadoras em concentrações próximas às efetivas contra Leishmania. Primeiramente verificamos que tamoxifeno foi capaz de induzir rapidamente a alcalinização de vacúolos de macrófagos peritoniais contendo amastigotas de L. (L.) amazonensis, sendo este um efeito observado em períodos curtos e longos de incubação com a droga. Esta alcalinização parece não estar diretamente relacionada à morte dos parasitas pela alteração imediata das condições ideais do meio necessário à sobrevivência das formas amastigotas, mas sim ligada ao aumento do efeito leishmanicida de tamoxifeno, uma vez que este 
composto apresentou-se mais ativo na faixa de $\mathrm{pH}$ neutro a moderadamente alcalino. Outro alvo investigado foi a biossíntese de isoprenóides de promastigotas. Células tratadas com tamoxifeno apresentaram redução global na biossíntese de farnesol, geraniol, dolicol, ergosterol e ubiquinona após marcação metabólica com $\left[{ }^{14} \mathrm{C}\right]$-leucina, indicando que tamoxifeno não interfere especificamente na síntese de cada um destes produtos. Iniciamos também a investigação dos efeitos do tamoxifeno no metabolismo de ceramidas em Leishmania adotando a estratégia de marcação metabólica de promastigotas com $\mathrm{C}_{6}$-NBDceramida. Verificamos que promastigotas de Leishmania são capazes de incorporar eficientemente ceramida conjugada ao fluoróforo NBD. Em nossos ensaios, a incubação de promastigotas tanto com os inibidores clássicos da via de biossíntese de esfingolipídios como com tamoxifeno resultou na alteração do perfil de incorporação dos precursores utilizados. O tratamento com tamoxifeno aumentou a biossíntese de glucosilceramida acetilada, elevou os níveis de ceramida acilada e diminuiu a biossíntese de fosfoesfingolipídios de promastigotas de L. (L.) amazonensis. Finalmente, nossos dados mostraram ainda que tamoxifeno permeabiliza a membrana plasmática de promastigotas de L. (L.) amazonensis e, a partir de estudos por microscopia eletrônica de transmissão, verificamos que este fármaco alterou a estrutura mitocondrial dos parasitas e provocou intensa vacuolização do citoplasma. Os resultados apresentados neste trabalho configuram o primeiro relato da atividade de tamoxifeno contra Leishmania e justificam a realização de futuros testes deste fármaco como uma alternativa na quimioterapia da leishmaniose.

Palavras-chave: Leishmania. Leishmaniose. Quimioterapia. Infecção Experimental. Tamoxifeno. Esfingolipídios. 


\section{ABSTRACT}

Miguel DC. Activity of tamoxifen in the treatment of experimental leishmaniasis and investigation on its mechanisms of action. [Ph.D. thesis (Parasitology)]. São Paulo: Instituto de Ciências Biomédicas da Universidade de São Paulo; 2011.

The treatment of cutaneous and visceral leishmaniasis is challenging, since the drugs used are frequently ineffective, very toxic and require parenteral administration. Therefore, the discovery of new drugs with leishmanicidal activity is in pressing need. The objective of this thesis was to characterize the activity of tamoxifen, a drug used in the treatment of breast cancer for decades, against Leishmania spp. in vitro and in vivo, and to identify its possible mechanism of action. The inhibitory concentrations of tamoxifen for $50 \%$ of parasite cultures, from reference strains and recent isolates from patients, ranged from 5 to $20 \mu \mathrm{M}$. Moreover, we showed that the intraperitoneal administration of $20 \mathrm{mg} / \mathrm{kg} / \mathrm{day}$ tamoxifen citrate for two weeks led to significant reductions in the lesion and ulcer sizes and parasite burden in L. (L.) amazonensis-infected BALB/C mice. Additionally, the administration of tamoxifen in two other models of animal infection proved its effectiveness against $L$. (L.) chagasi and $L(V$.$) braziliensis. In an attempt to characterize tamoxifen's mechanism of$ action against Leishmania, we found that this drug was able to induce a rapid alkalinization of macrophage vacuoles containing L. (L.) amazonensis amastigotes. This phenomenon does not appear to be related to the death of the parasites, but rather is linked to an increased antileishmanial effect of tamoxifen. Another target investigated was the interference of tamoxifen in the biosynthesis of isoprenoids. Treated cells showed an overall reduction in the biosynthesis of farnesol, geraniol, dolichol, ergosterol and ubiquinone after metabolic labeling with $\left[{ }^{14} \mathrm{C}\right]$-leucine, indicating that tamoxifen does not interfere specifically in the synthesis of those products. We have also studied the effects of tamoxifen on Leishmania ceramide metabolism. The strategy adopted was the metabolic labeling of promastigotes with $\mathrm{C}_{6}$-NBD-ceramide. Our results showed that Leishmania is able to incorporate NBDceramide. The incubation of promastigotes with classical inhibitors of sphingolipid 
biosynthesis as well as with tamoxifen resulted in striking modifications in the pattern of sphingolipid biosynthesis. L. (L.) amazonensis promastigotes treated with tamoxifen showed increased biosynthesis of acetylated glucosylceramide and acyl-ceramide and decreased synthesis of phosphosphingolipids. Finally, our data showed that tamoxifen induced the permeabilization of the promastigote plasma membrane and, based on studies using transmission electron microscopy, we found that this drug altered the mitochondrial structure and caused intense cytoplasmic vacuolization. The results presented here comprise the first report of the activity of tamoxifen against Leishmania and offer support for future trials to evaluate tamoxifen as an alternative for leishmaniasis chemotherapy.

Key words: Leishmania. Leishmaniasis. Chemotherapy. Experimental Infection. Tamoxifen. Sphingolipids. 


\section{LISTA DE ABREVIATURAS E SIGLAS}

BSA

BCA

C18

$\mathrm{CC}_{50}$

CDase

Cer

$\mathrm{cm}^{2}$

$\mathrm{CO}_{2}$

CoA

CoQ

Cpm

D11 e D12

$\mathrm{Da}$

DTT

EDTA

EPB

Erg

$\mathrm{F}$

G

g

GC

h

HPLC

HPTLC

$\mathrm{IC}_{50}$

$\mathrm{IC}_{90}$

iNOS

IP

IPC

$\mathrm{kDa}$
Albumina de soro bovino

Ácido bicinconínico

Coluna de fase reversa de 18 átomos de carbono

Concentração citotóxica para 50\% da cultura

Ceramidase

Ceramida

Centímetro quadrado

Gás carbônico

Coenzima A

Coenzima Q

Contagens por minuto

Dolicóis de 11 e 12 unidades isoprênicas

Dalton

Ditiotreitol

Ácido etileno diamino tetracético

Tampão de eletroporação

Ergosterol

Farnesol

Geraniol

Grama

Glucosilceramida

Hora

Cromatografia líquida de alta performance

Cromatografia em camada delgada de alta performance

Concentração inibitória para 50\% da cultura

Concentração inibitória para $90 \%$ da cultura

Óxido nítrico sintase induzida

lodeto de Propídio

Inositol-fosforilceramida

Quilodalton 


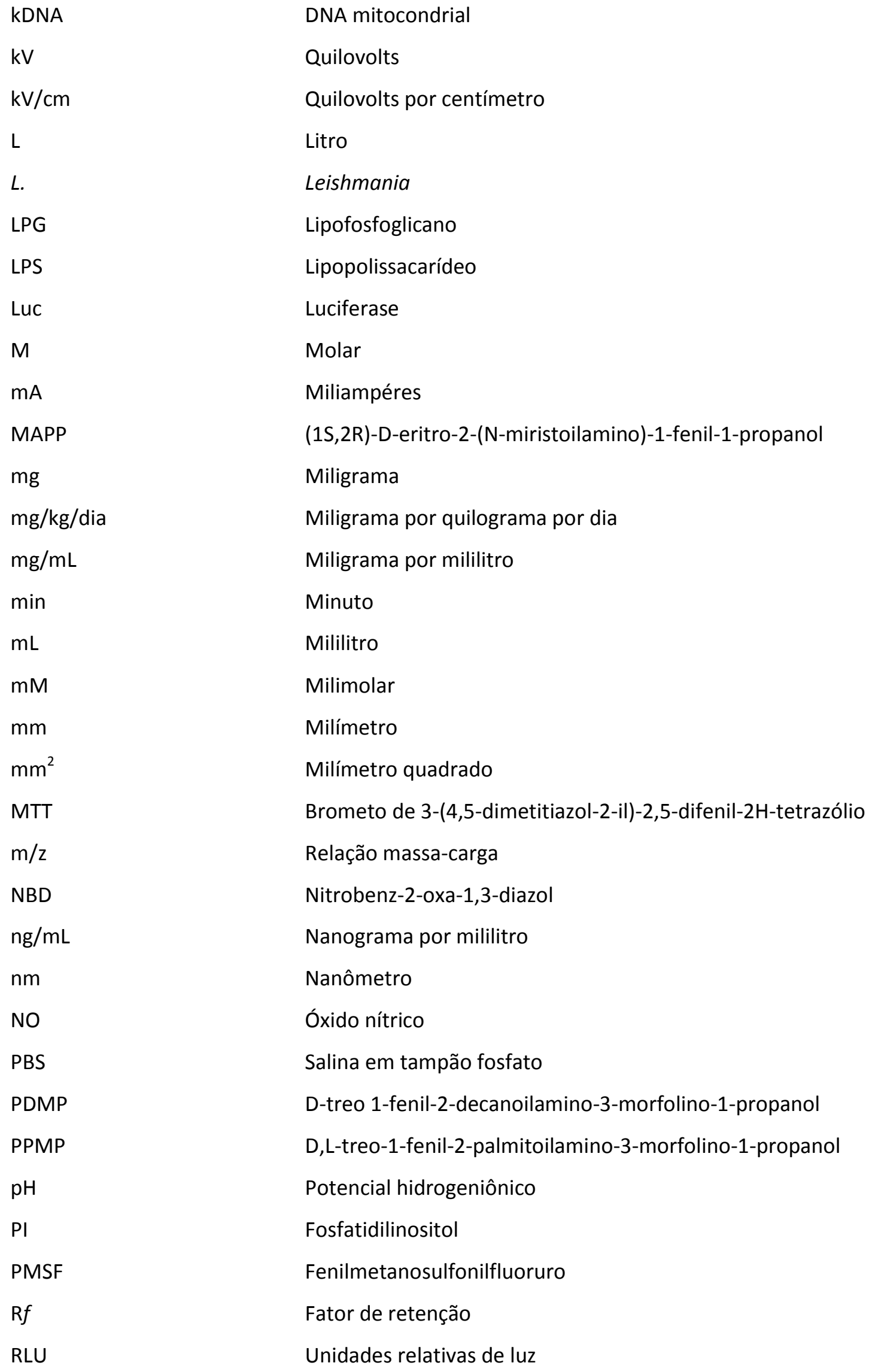




\begin{tabular}{|c|c|}
\hline SDS - PAGE & Eletroforese em gel de poliacrilamida contendo SDS \\
\hline SDS & Dodecil sulfato de sódio \\
\hline$S$ & Segundo \\
\hline SFB & Soro fetal bovino \\
\hline SNAFL-calceína AM & Semi-nafto-fluorescein-calceína, acetóxi-metil éster \\
\hline TBST & Tampão com Tris, $\mathrm{NaCl}$ e Tween \\
\hline TOF & Analisador por tempo de voo \\
\hline TEMED & $\mathrm{N}, \mathrm{N}, \mathrm{N}^{\prime}, \mathrm{N}^{\prime}$-tetrametilnodiamina \\
\hline Tris & Tris (hidroximetilaminometano) \\
\hline $\mathrm{U} / \mathrm{mL}$ & Unidades por mililitro \\
\hline UV & Ultravioleta \\
\hline MALDI-TOF MS & $\begin{array}{l}\text { Espectrometria de massas por tempo de voo com ionização e } \\
\text { dessorção a laser assistida por matriz }\end{array}$ \\
\hline V & Volts \\
\hline V. & Viannia \\
\hline$v / v$ & Volume/volume \\
\hline$v / v / v$ & Volume/volume/volume \\
\hline $\mathrm{xg}$ & Gravidade \\
\hline${ }^{\circ} \mathrm{C}$ & Graus Celsius \\
\hline$\mu \mathrm{Ci}$ & MicroCurie \\
\hline$\mu \mathrm{F}$ & MicroFaraday \\
\hline$\mu \mathrm{g}$ & Micrograma \\
\hline$\mu \mathrm{g} / \mathrm{mL}$ & Micrograma por mililitro \\
\hline$\mu \mathrm{L}$ & Microlitro \\
\hline$\mu \mathrm{m}$ & Micrômetro \\
\hline
\end{tabular}




\section{SUMÁRIO}

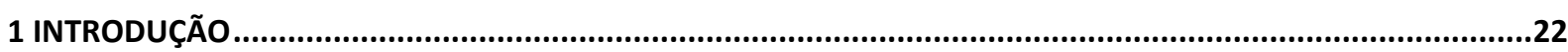

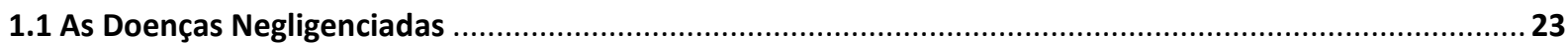

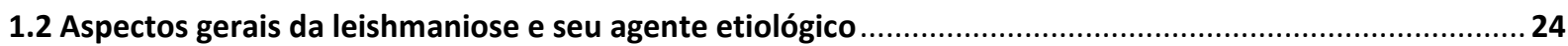

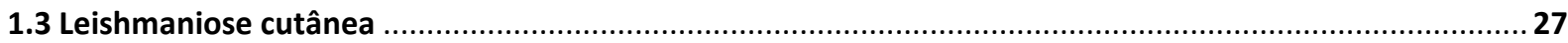

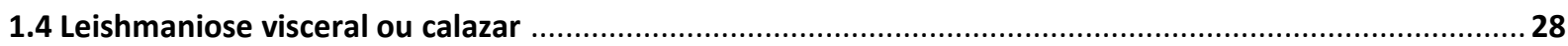

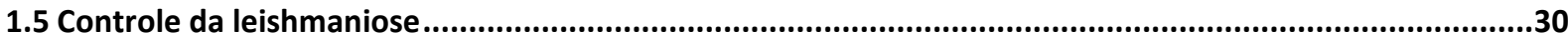

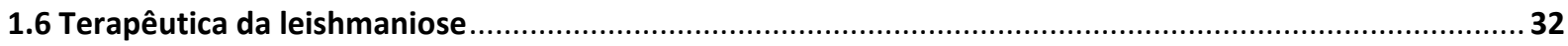

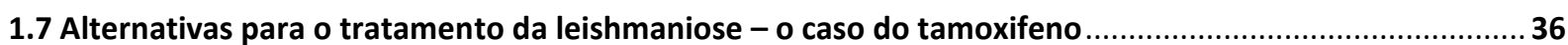

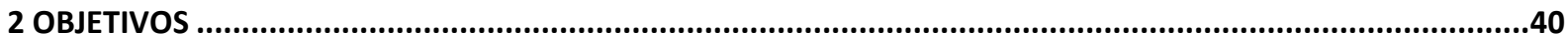

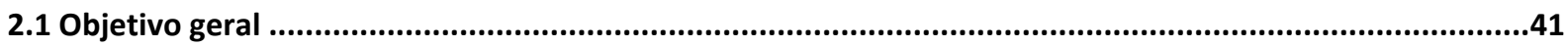

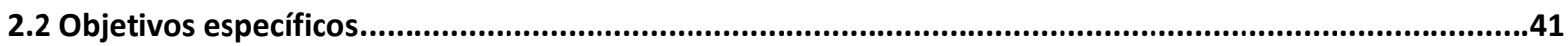

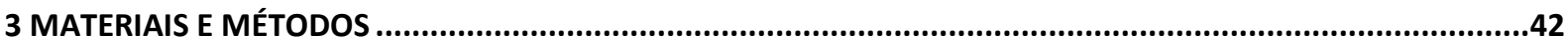

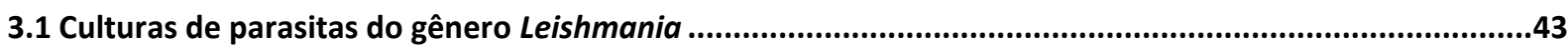

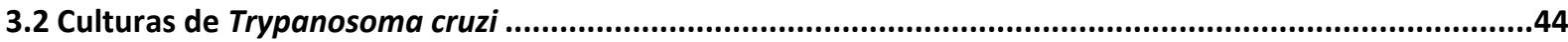

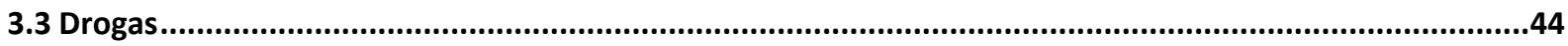

3.4 Ensaios de inibição de crescimento de promastigotas e amastigotas de Leishmania .............................45

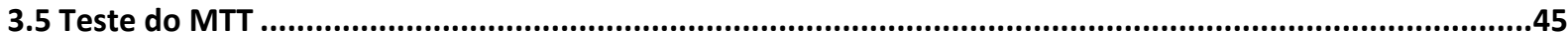

3.6 Obtenção de macrófagos e ensaios de inibição de infecção in vitro .......................................................46

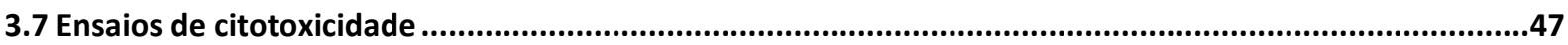

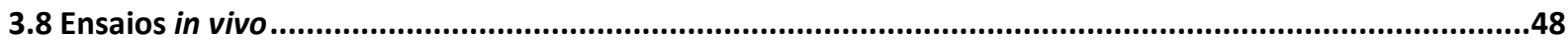

3.9 Quantificação de parasitas - Diluição Limitante e imprints .................................................................50

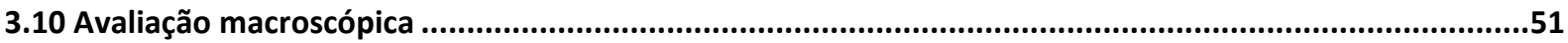

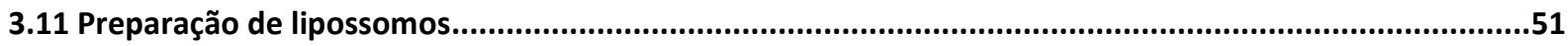

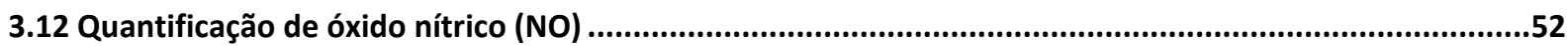

3.13 Eletroforese em gel de poliacrilamida contendo SDS (SDS-PAGE) e Western blot ..............................52

3.14 Ensaios para avaliação da alteração do pH de vacúolos macrofágicos.................................................54

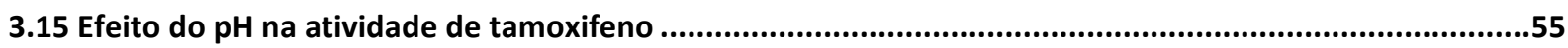


3.16 Marcação metabólica e extração de isoprenoides de $L$. (L.) amazonensis .............................................55

3.17 Cromatografia em camada delgada de alta performance (HPTLC) de isoprenoides ...............................56

3.18 Cromatografia líquida de alta performance (HPLC) de isoprenoides .............................................56

3.19 Marcação com iodeto de propídio e citometria de fluxo ............................................................57

3.20 Separação de fração de membrana e citosólica de promastigotas ....................................................57

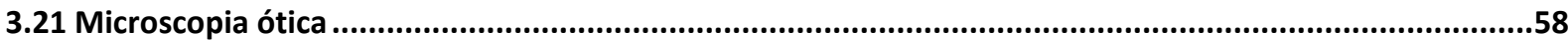

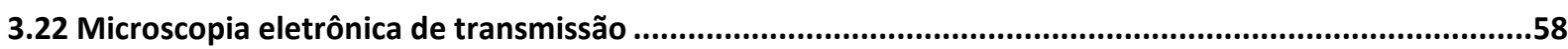

3.23 Investigação do metabolismo de esfingolipídios em $L$. (L.) amazonensis..........................................59

3.23.1 Ensaios de viabilidade celular na presença de Fumonisina B1, MAPP, PDMP e PPMP .......................59

3.23.2 Incorporação de $C_{6}$-NBD-ceramida por promastigotas de L. (L.) amazonensis ....................................59

3.23.3 Marcação metabólica, extração lipídica de L. (L.) amazonensis e HPTLC ..........................................60

3.23.4 Deteç̧ão de ceramida por imunofluorescência e citometria de fluxo ............................................61

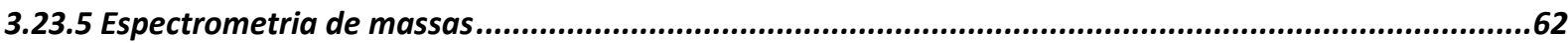

3.24 Obtenção da linhagem $L$. (L.) amazonensis expressora do gene LUC .............................................62

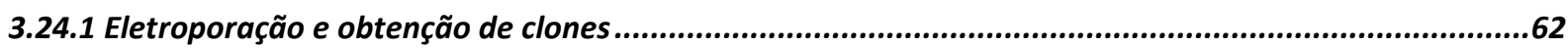

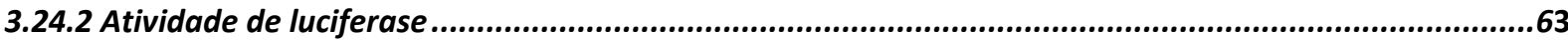

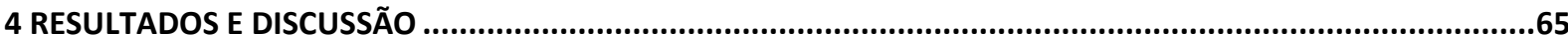

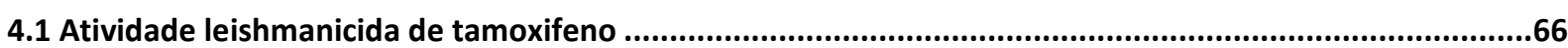

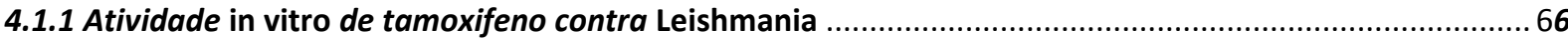

4.1.2 Atividade de tamoxifeno no tratamento de leishmaniose em modelo de roedores ..............................67

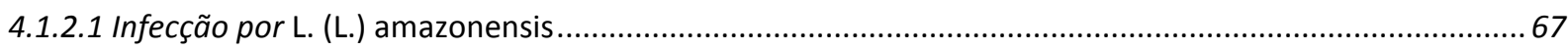

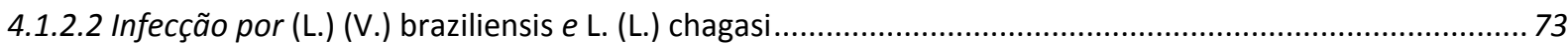

4.1.3 Atividade do metabólito 4-hidróxi-tamoxifeno contra L. (L.) amazonensis...........................................73

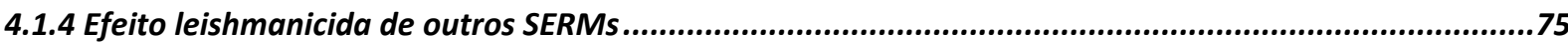

4.1.5 Sensibilidade de isolados de pacientes ao tamoxifeno ...............................................................78

4.1.6 Atividade tripanossomicida de tamoxifeno in vitro $e$ in vivo .....................................................79

4.2 Investigação de mecanismos de ação do tamoxifeno em $L$. (L.) amazonensis .......................................80

4.2.1 Tamoxifeno não atua como um modulador seletivo do receptor de estrógeno (SERM) contra

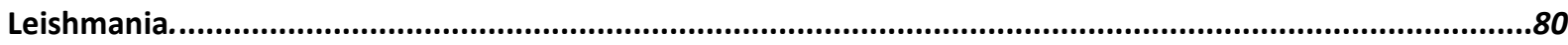

4.2.2 Tamoxifeno não altera os níveis de óxido nítrico (NO) em infecções in vitro .........................................81

4.2.3 Tamoxifeno alcaliniza vacúolos fagolisossômicos parasitados por L. (L.) amazonensis .......................83 
4.2.4 Interferência de tamoxifeno no metabolismo de isoprenoides de Leishmania

4.2.4.1 Tamoxifeno permeabiliza a membrana plasmática de promastigotas de L. (L.) amazonensis.

4.2.5 Tamoxifeno altera a morfologia e ultraestrutura de promastigotas de L. (L.) amazonensis

4.3 Interferência do tamoxifeno no metabolismo de esfingolipídios de Leishmania . .93

4.3.1 Esfingolipídios em Leishmania spp.

4.3.2 Incorporação de $C_{6}$-NBD-ceramida por promastigotas de L. (L.) amazonensis...................................97

4.3.3 Atividade leishmanicida dos inibidores Fumonisina B1, MAPP, PDMP e PPMP ..................................98

4.3.4 Incorporação de $C_{6}$-NBD-ceramida em parasitas tratados com MAPP, PDMP e tamoxifeno .103

4.3.5 Modulação da biossíntese de esfingolipídios de L. (L.) amazonensis por tamoxifeno .106

4.4 Aperfeiçoamento de estratégias experimentais para avaliação da atividade de drogas contra Leishmania

4.4.1 Estabelecimento de linhagem de L. (L.) amazonensis expressora do gene LUC

4.5 Participação em projetos paralelos

5 CONCLUSÕES

REFERÊNCIAS

ANEXO A - Tamoxifen is effective against Leishmania and induces a rapid alkalinization of parasitophorous vacuoles harbouring Leishmania (Leishmania) amazonensis amastigotes

ANEXO B - Tamoxifen as a potential antileishmanial agent: efficacy in the treatment of Leishmania braziliensis and Leishmania chagasi infections

ANEXO C - Tamoxifen is effective in the treatment of Leishmania amazonensis infections in mice .158

ANEXO D - Clinical isolates of New World Leishmania from cutaneous and visceral leishmaniasis patients are uniformly sensitive to tamoxifen

ANEXO E - The anticancer drug tamoxifen is active against Trypanosoma cruzi in vitro but ineffective in the treatment of the acute phase of Chagas disease in mice 
1 INTRODUÇÃO 


\subsection{As Doenças Negligenciadas}

O termo Doenças Negligenciadas (DNs) refere-se a doenças de alto impacto social que acometem regiões pobres e emergentes no mundo e, por isso, despertam interesse restrito da indústria farmacêutica e do meio acadêmico (Lapa e Silva, 2008). A Organização Mundial da Saúde (World Health Organization, WHO) considera atualmente cerca de 20 enfermidades excluindo a malária e a tuberculose como DNs de alta importância, incluindo a dengue, esquistossomose, hanseníase, helmintíases adquiridas pelo contato com solo, leishmaniose em suas diversas manifestações clínicas e tripanossomíase africana e americana (WHO, 2010). Estudos apontam que parcelas inferiores a $10 \%$ do auxílio financeiro direcionado para pesquisas destinam-se aos programas nos quais se enquadram as DNs quando comparados ao investimento na pesquisa em AIDS, malária e tuberculose. Algumas DNs como helmintíases intestinais podem acometer grandes contingentes da população, levando a infecções crônicas e baixas taxas de mortalidade, enquanto outras como a tripanossomíase africana e a leishmaniose visceral atingem uma parcela relativamente menor da população, embora sendo muitas vezes rapidamente fatais (All-Party Parliamentary Malaria Group - APPMG, 2008/9). Segundo estimativas da Organização Pan-Americana da Saúde (PAHO), escritório regional da WHO nas Américas, aproximadamente 570 milhões de pessoas residentes em países caribenhos e latino-americanos em 2005 estavam expostas ao risco de infecção por alguma DN. Deste total da população: $17,6 \%$ encontravam-se infectados por Trichuris, $14,6 \%$ por Ascaris, 6\% por ancilostomídeos e 3,2\% por Trypanosoma cruzi.

Estimativas apontavam que 1,6\% da população brasileira (cerca de 3 milhões de casos) encontrava-se infectada por Schistosoma mansoni em 2005 e mais de 3.500 casos de leishmaniose visceral haviam sido reportados em 2004 (PAHO/WHO, 2007). Além disso, o Brasil detem a maioria dos casos de DNs da América Latina e Caribe, segundo levantamento realizado por Hotez em editorial publicado no periódico PLoS Neglected Tropical Diseases (Hotez, 2008).

Além de causarem sofrimento massivo, anemia, desnutrição, deformação e deficiência física em estágios crônicos, as DNs levam a altos níveis de mortalidade, ocasionando prejuízos 
sociais e econômicos para as populações afetadas (Hotez et al., 2009; Feasey et al., 2010). Embora bem sucedidos, recentes investimentos em políticas de saúde pública objetivando o controle das DNs - como os programas de erradicação da dracunculíase, hanseníase e oncocercíase (Feasey et al., 2010) - ainda se mostram incipientes na redução do impacto global das DNs, visto que o número de casos de infecções por diversos protozoários e helmintos vem aumentando nas últimas décadas. Tal realidade representa um enorme desafio para os governos de países pobres e em desenvolvimento, incluindo o Brasil, que urgentemente necessitam estabelecer políticas de rotina de vigilância epidemiológica e coleta de dados para as DNs, bem como ampliar o investimento em pesquisas de novas ferramentas para diagnósticos mais eficazes, desenvolvimento de vacinas e novas alternativas quimioterápicas para o tratamento dos doentes (Morel et al., 2005; Hotez e Ferris, 2006; Hotez et al., 2009).

\subsection{Aspectos gerais da leishmaniose e seu agente etiológico}

Conforme citado anteriormente, a leishmaniose é uma das mais impactantes DNs por ocupar a quinta posição em prevalência no mundo, com casos registrados em 88 países distribuídos em 4 continentes (Figura 1). Anteriormente considerada uma doença rural, a leishmaniose vem se expandido para áreas mais urbanizadas com estimativa de 1,6 milhão de pessoas infectadas por ano, sendo 500 mil casos da forma visceral (basicamente concentrados em Bangladesh, Brasil, Etiópia, Índia, Nepal e Sudão) e mais de um milhão de casos da forma cutânea - incluindo suas subdivisões clínicas - ocorrendo em sua maioria no Afeganistão, Arábia Saudita, Argélia, Bolívia, Brasil, Irã, Peru, Síria e Sudão (WHO, 2010). A expansão do número de doentes tornou-se evidente a partir da década de 1990 e se estende até os dias atuais. No Brasil, por exemplo, foi verificado o aumento no número de casos de leishmaniose visceral principalmente na região Nordeste, além da detecção de casos da forma cutânea para todos os estados da Federação. Isso pode ser explicado principalmente pela mudança no padrão de distribuição geográfica da doença que se propagou para áreas periféricas de 
grandes centros urbanos associada à invasão e ocupação indevida de áreas de mata. Todavia, também deve ser considerado o processo de organização da rede de assistência relacionada ao diagnóstico e tratamento levando à detecção mais efetiva do número de casos (PAHO/WHO, 2007). Países como o Afeganistão, em 2002, e a Etiópia, em 2005, experimentaram grandes epidemias de leishmaniose cutânea e visceral, respectivamente (WHO, 2010).
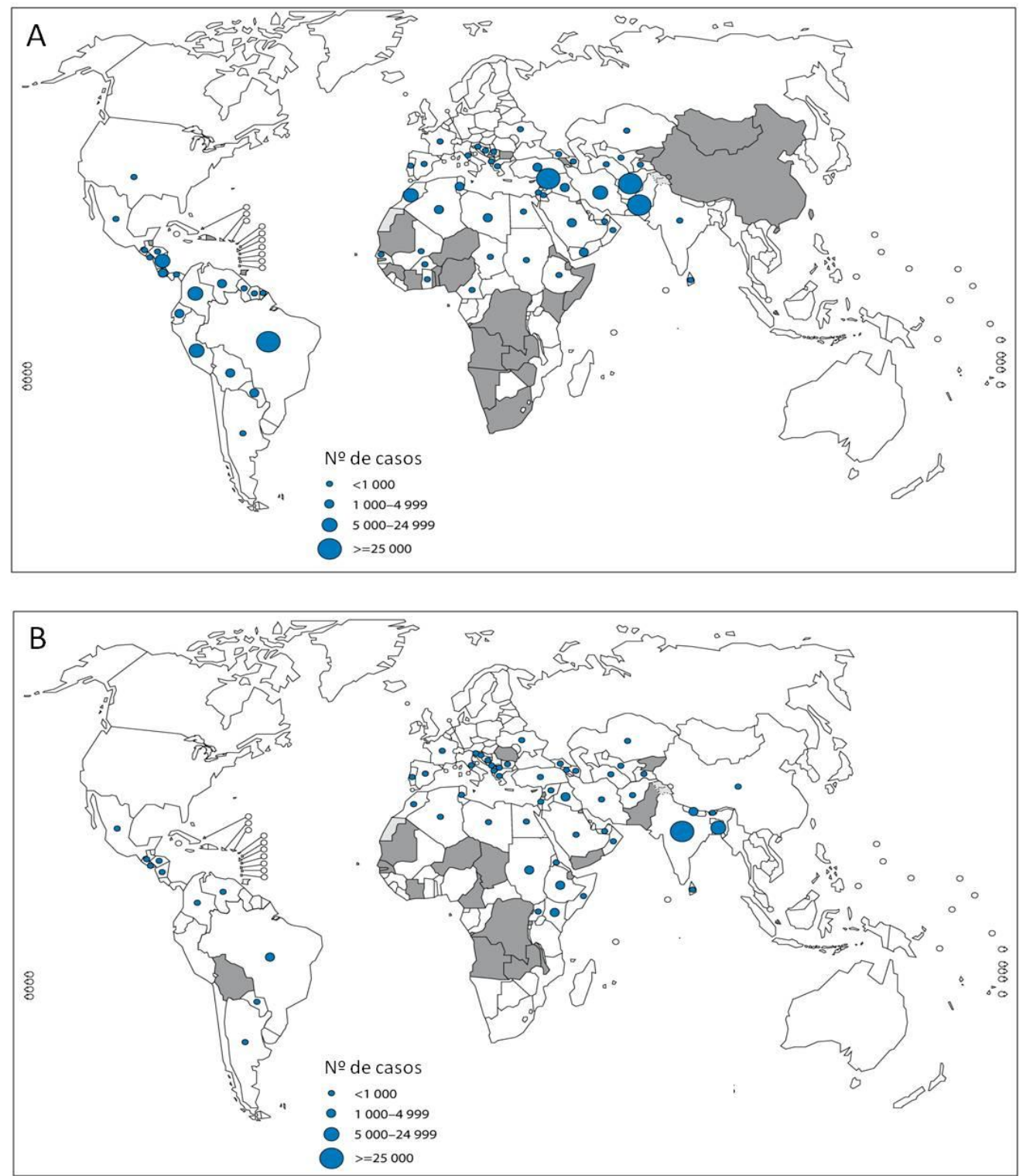

Figura 1. Distribuição global da leishmaniose cutânea (A) e visceral (B) segundo levantamento de número de casos realizado pela Organização Mundial da Saúde entre 2005 e 2009. Os países em cinza destacamse pela endemia, porém, sem registros oficiais do número de casos. Fonte: Adaptado de WHO, 2010 - First WHO Report on Neglected Tropical Diseases, 2010. 
Os agentes causadores da leishmaniose são protozoários pertencentes ao gênero Leishmania, família Trypanosomatidae e ordem Kinetoplastida. São parasitas heteroxenos, sendo assim, alternam o ciclo biológico entre hospedeiros distintos: um invertebrado (limitando-se à infecção de fêmeas de insetos flebotomíneos dos gêneros Phlebotomus no Velho Mundo e Lutzomyia no Novo Mundo) e um vertebrado (abrangendo diversas classes de mamíferos e alguns répteis) (Lainson e Shaw, 1987). Ao longo do ciclo, os parasitas sofrem importantes alterações morfológicas e bioquímicas, mas ainda assim conservam uma típica estrutura flagelar proeminente ou reduzida e o cinetoplasto. Este último, ao qual o nome dado à ordem faz referência, consiste em um aglomerado de moléculas de DNA circulares dotado de um complexo mecanismo de replicação que está encerrado na mitocôndria única do parasita (revisado por Liu et al., 2005).

Durante seu ciclo de vida, o parasita é tomado pelo inseto hematófago flebotomíneo durante a ingestão de sangue de um animal infectado. Neste caso, o estágio parasitário é denominado amastigota, consistindo em uma forma arredondada obrigatoriamente intracelular e de flagelo reduzido. Ao atingirem o tubo digestivo do inseto vetor há a transformação das formas amastigotas para promastigotas (forma flagelada, fusiforme e extracelular), que permanecem aderidos às microvilosidades do intestino médio. Após 4 a 7 dias, período que varia de acordo com a espécie de Leishmania, diversas modificações na morfologia e na superfície celular do parasita ocorrem, permitindo em última instância a liberação dos promastigotas dos microvilos que se acumulam no esôfago do inseto. 0 processo de diferenciação que ocorre no intestino do vetor é denominado metaciclogênese e é caracterizado pela transformação das formas que se dividem (promastigotas procíclicos), em formas menores altamente móveis incapazes de se dividir, denominadas promastigotas metacíclicos. Quando o inseto realizar um novo repasto sanguíneo, os promastigotas metacíclicos serão inoculados no hospedeiro mamífero, onde terão de subverter os mecanismos de defesa inatos e infectar principalmente macrófagos permanecendo no interior de fagolisossomos. Sinais como o aumento da temperatura e a diminuição do pH são cruciais para a diferenciação da forma promastigota para amastigota que se dividirá até a ruptura da célula hospedeira. Os amastigotas liberados são então fagocitados por outras células da linhagem macrofágica tanto localmente quanto em tecidos distantes após a disseminação 
(Lainson e Shaw, 1987; Sacks e Kamhawi, 2001; Rey, 2008). Após períodos de semanas a meses, a leishmaniose pode se manifestar em diferentes formas clínicas. Hospedeiros humanos são geralmente acidentais. Classicamente apresentam a forma cutânea, que pode atingir a pele, linfonodos e mucosas, ou a forma visceral da doença com comprometimento do baço, medula óssea e fígado. Essa última é capaz de provocar a morte do indivíduo não tratado (Ashford, 2000; Murray et al., 2005).

Cerca de 20 espécies transmitidas por aproximadamente 30 espécies de flebotomíneos levam ao amplo espectro clínico da leishmaniose, que também será influenciado pela resposta imune do hospedeiro além de variações regionais (Herwaldt, 1999; Handman, 2001; Murray et al. 2005).

\subsection{Leishmaniose cutânea}

Na leishmaniose cutânea o período de incubação varia de duas semanas a dois meses após a picada do inseto (Grimaldi, 1982). A doença se inicia com pequenas pápulas eritematosas, que aumentam vagarosamente de tamanho, transformando-se em nódulos e posteriormente em lesões ulceradas (Rey, 2008). A ocorrência da leishmaniose cutânea no Novo Mundo está principalmente associada às seguintes espécies: Leishmania (Viannia) braziliensis, Leishmania (Leishmania) amazonensis, L. (L.) mexicana, L. (V.) peruviana, L. (V.) panamensis e L. (V.) guyanensis. No Velho Mundo essa forma da doença ocorre principalmente na região do Mediterrâneo, Oriente Médio e sul da Ásia e as espécies envolvidas são L. (L.) major, L. (L.) tropica e L. (L.) aethiopica. No Brasil as espécies responsáveis pelas maiores taxas de infecção são L. (V.) braziliensis, L. (L.) amazonensis e $L$. (V.) guyanensis (Grimaldi, 1982; Rey, 2008).

A forma cutânea localizada pode evoluir para cura e cicatrização espontânea, apesar de requerer meses ou anos, a despeito da espécie causadora (Bern et al., 2008). Cerca de 1 a $10 \%$ dos casos de leishmaniose cutânea pode evoluir para uma manifestação clínica mais complexa denominada leishmaniose mucocutânea ou mucosa que no Brasil é causada por $L$. 
(V.) braziliensis e L. (V.) guyanensis (Amato et al., 2007; Guerra et al., 2011). Trata-se de uma forma grave que pode levar à destruição do septo nasal, palato e outras estruturas da mucosa, geralmente com resposta insatisfatória a drogas específicas. Em situações mais severas pode levar a mutilações faciais e em alguns casos mais raros levar a infecções bacterianas secundárias, com evolução para septicemia e óbito (Marsden, 1990; Oliveira et al., 2005; Velozo et al., 2006).

Outras manifestações raras da leishmaniose cutânea incluem as formas difusa, disseminada e recidivante, para as quais a resposta à terapêutica é pobre. A primeira, normalmente causada por L. (L.) amazonensis, evolui de forma lenta com formação de placas e múltiplas nodulações não ulceradas repletas de parasitas, recobrindo extensas áreas da pele. A forma disseminada pode ser causada por L. (V.) braziliensis e $L$ (L.) amazonensis e leva a um quadro de múltiplas lesões papulares não nodulares que acometem vários segmentos corporais, frequentemente a cabeça e o tronco. Por último, a forma recidivante apresenta-se como uma doença crônica que desencadeia a formação de lesão facial solitária com baixa carga parasitária. É causada por espécies do Velho Mundo, sendo mais comum em países do Oriente Médio (Franke et al., 1990; Convit et al., 1993; Herwaldt, 1999; Brasil - SVSFiocruz/Ministério da Saúde, 2011).

A distribuição de casos de leishmaniose cutânea no território brasileiro é ampla, atingindo todas as regiões, sendo a Norte a detentora do maior número de casos para o período de 2002 a 2009. De acordo com levantamento da Secretaria de Vigilância Sanitária do Ministério da Saúde, foram notificados 21.824 casos da doença no Brasil em 2009 (Brasil SINAN/SVS/Ministério da Saúde, 2010).

\subsection{Leishmaniose visceral ou calazar}

Trata-se de uma doença crônica e sistêmica de período médio de incubação entre 2 a 4 meses. Os sinais e sintomas consistem em febre de longa duração, emagrecimento, anemia, hepatomegalia, esplenomegalia, caquexia, micropoliadenopatia, hemorragias e leucopenia. Se 
não tratada, a doença evolui para o óbito em 1 a 2 anos após o aparecimento dos sintomas (Roberts e Janovy, 2000). As espécies causadoras são L. (L.) donovani na África Oriental, Índia e China, L. (L.) infantum no Mediterrâneo, outras regiões da África, Oriente Médio e China e, no continente americano, é atribuída à L. (L.) chagasi (sinonímia de L. (L.) infantum) (revisado em Mauricio et al., 2000; Rey, 2008).

Existem algumas variações da leishmaniose visceral clássica como a leishmaniose dérmica pós-calazar mais comumente decorrente de infecção por L. (L.) donovani, na qual há o aparecimento de lesões cutâneas secundárias meses ou anos após a resolução do calazar. Mais raramente, a leishmaniose viscerotrópica caracteriza-se por uma síndrome com baixas cargas parasitárias de manifestações não-específicas e causadas por L. (L.) amazonensis no Novo Mundo e L. (L.) tropica no Velho Mundo (Barral et al., 1991; Herwaldt, 1999).

Embora tenha caráter reconhecidamente zoonótico, a leishmaniose visceral na Índia, Paquistão e Bangladesh é uma antroponose, ou seja, o homem é um hospedeiro que participa do ciclo também como reservatório. Tal fato leva a implicações importantes como o aumento no número de pacientes refratários ao tratamento clássico devido à resistência dos parasitas às drogas e o favorecimento da expansão da doença em países populosos como recentemente descrito para uma região não-endêmica do Nepal (Pandey et al., 2011). No caso do Brasil a transmissão envolve canídeos selvagens e cães domésticos. Os cães, apresentando ou não sintomas, podem ser fontes de transmissão atuando como reservatório, o que torna o controle da população dos animais infectados altamente complexo (Lainson e Rangel, 2001). Frequentemente surtos de leishmaniose visceral são temporal e espacialmente precedidos por epidemias caninas, como ocorrido no município de Belo Horizonte entre 1993 e 1996 (Bevilacqua et al., 2001).

O aumento do número de casos de leishmaniose visceral no Brasil ganhou força a partir dos anos 1990, com destaque para os estados do Pará e Tocantins (região Norte), Mato Grosso do Sul (Centro-Oeste), Minas Gerais e São Paulo (Sudeste). No período de 2004 a 2009, os casos brasileiros confirmados para a doença foram superiores a 3500/ano. No ano de 2009, só a região Nordeste contabilizou $47 \%$ dos casos brasileiros, com destaque para o estado do Ceará apresentando 629 casos (Brasil - SINAN/SVS/Ministério da Saúde, 2010). 
Um fator crucial que deve ser levado em consideração no que diz respeito à incidência da leishmaniose é a sua associação com quadros de imunossupressão, como em pacientes transplantados (Machado et al., 2009) e principalmente em pacientes com síndrome da imunodeficiência adquirida. Na Etiópia, por exemplo, as taxas de co-infecção HIV/Leishmania estão entre 15 a 30\% (WHO, 2011). Na década de 1990, países europeus como Espanha, Portugal, França e Itália apresentavam alta prevalência desta co-infecção, porém, mais recentemente, o uso disseminado da terapia antirretroviral tem sido acompanhado de declínio no número de casos. Situação inversa é observada quando se trata da prevalência da co-infecção HIV/Leishmania em países da África Subsaariana e do sul da Ásia, que vem aumentando significativamente nos últimos anos (Alvar et al., 2008; Lloyd-Smith et al., 2008). No caso do Brasil, recentes trabalhos reportaram o aumento na incidência desta co-infecção no Nordeste e Centro-Oeste. No estado do Mato Grosso do Sul foi verificado que a leishmaniose visceral é a primeira infecção oportunista para $60 \%$ dos casos de pacientes HIVpositivos (Botelho e Natal, 2009; Alexandrino-de-Oliveira et al., 2010; Nascimento et al., 2011). Em indivíduos portadores do vírus HIV com severa imunossupressão, o quadro de leishmaniose visceral costuma ser bastante grave com comprometimento de áreas não-usuais como o trato gastrointestinal. Na ausência de terapia antirretroviral eficaz as taxas de recaída após tratamento podem chegar a 100\% (revisado em Bern et al., 2008). Herwaldt assinala que as tendências de invasão urbana da leishmaniose e da expansão da infecção pelo HIV para áreas rurais são fatores capazes de promover o aumento no número de pacientes coinfectados por HIV/Leishmania no mundo (Herwaldt, 1999).

\subsection{Controle da leishmaniose}

O controle da leishmaniose deve ser estabelecido de acordo com os aspectos ecoepidemiológicos das diferentes formas da doença (revisado em Vioukov, 1987). A forma zoonótica requer uma série de medidas que envolvem: 
a. Controle direto do vetor (controle químico, ecológico, biológico ou genético);

b. Controle do agente etiológico baseado no tratamento de doentes a exemplo do ocorrido na China, onde significativa redução no número de casos de leishmaniose visceral foi verificada após intenso trabalho de tratamento e cuidado à população doente;

c. Controle da fonte de infecção (eliminação ou contenção de animais que sirvam como reservatórios para o parasita);

d. Proteção do indivíduo contra a infecção através do uso de repelentes contra flebotomíneos e eventualmente pela utilização de uma vacina.

Ainda nos dias de hoje não existe nenhuma vacina disponível contra a leishmaniose. É consenso que uma vacina capaz de imunizar o homem ou mesmo uma vacina eficaz para cães tornar-se-ia a medida profilática ideal no controle da leishmaniose. Contudo, diversos obstáculos ainda precisam ser ultrapassados para que se estabeleça uma vacina ativa e segura. Dentre as maiores dificuldades estão: a falta de conhecimento acerca da complexidade dos mecanismos imunológicos decorrentes da infecção por Leishmania; a transposição de testes em modelos de infecção animal para testes pré-clínicos e clínicos; a busca por antígenos ideais que se mostrem capazes de ativar uma resposta protetora persistente contra a infecção, entre outros (Vioukov, 1987; Kedzierski et al., 2006). Em relação ao uso de repelentes, existem controvérsias em alguns estudos disponíveis na literatura, uma vez que a ação repelente de inseticidas aplicados diretamente na pele pode ter ação variável e, muitas vezes, as pessoas subestimam a importância dos flebotomíneos em relação à picada de outros insetos. Quanto à impregnação de inseticidas em telas de proteção, um ensaio clínico randomizado e pareado realizado recentemente mostrou que o uso de redes contendo repelentes não preveniu infecções por $L$. (L.) donovani na Índia e Nepal quando comparado ao uso de sprays residuais ou mesmo redes de proteção não impregnadas com repelentes (Vioukov, 1987; Moosa-Kazemi et al., 2007; Picado et al., 2010). Contudo, como sinaliza Desjeux (2010), estudos como o de Picado e colaboradores devem ser realizados com o intuito de se aperfeiçoar um método repelente eficaz contra a picada destes insetos, a exemplo do sucesso com o uso de telas de proteção em áreas devastadas pela malária (Desjeux, 2010). 
Já a forma antroponótica da doença deve ser controlada a partir da erradicação da população de flebotomíneos em áreas endêmicas, que pode ser alcançada por medidas como aquelas citadas anteriormente, além da melhoria de condições sanitárias e de limpeza que auxiliem na eliminação de focos de reprodução do inseto vetor. A partir da redução nas taxas de infecção, torna-se mais bem sucedida a detecção de casos e, finalmente, o tratamento dos doentes passa a se configurar como a principal forma de controle da leishmaniose (Vioukov, 1987; Bern e Chowdhury, 2006).

\subsection{Terapêutica da leishmaniose}

Além do tratamento da leishmaniose ser de importância inegável para a melhora do paciente, é possível notar a partir das informações acima que este se configura como uma importante estratégia de controle da doença. Infelizmente, porém, os medicamentos em uso na clínica estão sobremaneira distantes de serem ideais (revisado em Dujardin et al., 2010).

A terapêutica das leishmanioses é baseada principalmente no uso de antimoniais, cuja aplicação foi introduzida pelo brasileiro Gaspar Vianna em 1912 a partir do tártaro emético para tratamento da leishmaniose mucocutânea (Rey, 2008). Atualmente utilizam-se os antimoniais pentavalentes estibogluconato de sódio ou antimoniato de meglumine (Glucantime $^{\circledR}$, Sanofi-Aventis, Suzano, São Paulo, Brasil) como drogas de primeira escolha tanto para leishmaniose visceral quanto para a cutânea. Esses medicamentos são de administração parenteral obrigatória por pelo menos 20 dias, apresentam eficácia variável e podem provocar efeitos adversos, alguns dos quais bastante graves como arritmias cardíacas, pancreatite e nefro e hepatotoxicidade (revisado em Singh e Sivakumar, 2004). Apesar do uso difundido do estibogluconato de sódio, sua estrutura química ainda não foi totalmente elucidada. Contudo, acredita-se que sua eficácia contra as formas amastigotas possa estar relacionada à sua conversão em uma estrutura trivalente letal para esse estágio do parasita (revisado em Croft e Coombs, 2003). Uma série de estudos demonstrou possíveis mecanismos de ação do estibogluconato de sódio que incluem a inibição na produção de ATP por 
interferência na glicólise e ß-oxidação de ácidos graxos (Berman et al., 1987), indução de morte celular do tipo apoptose (Sereno et al., 2001) e inibição de enzimas do parasita como a glutationa redutase e a tripanotiona redutase (Cunningham e Fairlamb, 1995).

Desde a década de 1980, relatos clínicos demonstraram que a administração de antimoniais já não se fazia mais tão eficaz na cura da leishmaniose visceral como na década anterior. Desde então foi preconizado o tratamento com doses superiores de antimoniais por períodos mais prolongados, mas que não surtiu o efeito esperado em regiões ao Norte da Índia, principalmente no estado de Bihar (Sundar et al., 2001). Entre 50 a 65\% dos pacientes desta região mostraram-se refratários ao tratamento, fato posteriormente explicado a partir da detecção de isolados de L. (L.) donovani altamente resistentes ao antimônio (Lira et al., 1999). Isolados obtidos de pacientes sudaneses também foram resistentes aos antimoniais em ensaios in vitro, resultado que concorda com os achados de Yardley e colaboradores para isolados do Peru em 2006 (Sharief et al., 2006, Yardley et al., 2006). No caso do Brasil o índice de sucesso terapêutico com Glucantime ${ }^{\circledR}$ era considerado alto, com aproximadamente $95 \%$ de cura. Em Teresina, Piauí, foi verificado que cerca de $5 \%$ dos pacientes não responderam ao tratamento com a droga de primeira escolha, requerendo tratamentos a partir de outros grupos de medicamentos (Santos et al., 2002; Werneck et al., 2003). Relatos mais recentes indicam, entretanto, que a eficácia do tratamento com antimoniais seja mais baixa (Tuon et al. 2008). Outro estudo realizado na região Amazônica mostrou que o tratamento com Glucantime ${ }^{\circledR}$ em pacientes com leishmaniose cutânea levou a índices de cura inferiores a 55\% (Chrusciak-Talhari et al., 2011).

As drogas de segunda escolha no tratamento de leishmaniose incluem a anfotericina $B$ e a pentamidina. O desoxicolato de anfotericina também é de administração parenteral e os efeitos tóxicos cumulativos são intensos. A utilização de anfotericina encapsulada em lipossomos ou associada a lipídios reduz a dose necessária para o tratamento da leishmaniose visceral, mas com custos normalmente restritivos para o tratamento em larga escala em zonas endêmicas (revisado em Murray, 2001). Entretanto, Sundar e colaboradores evidenciaram recentemente que o uso de uma única dose infundida de anfotericina $B$ lipossomal $(10 \mathrm{mg} / \mathrm{kg})$ foi equivalente à administração de 15 doses (1 dose $=1 \mathrm{mg} / \mathrm{kg}$ ) de desoxicolato de anfotericina em dias alternados durante 29 dias de hospitalização, inclusive com redução dos 
custos (Sundar et al., 2010). Existe um número limitado de estudos que sugerem a eficácia da formulação lipossomal para casos de leishmaniose tegumentar. Geralmente os relatos incluem pequenos grupos de pacientes ou indivíduos imunossuprimidos infectados que são tratados com a formulação após falha com antimoniais e, além disso, o tratamento mostra-se muitas vezes eficaz para infecções por determinadas espécies de Leishmania ou para uma dada região geográfica (Brown et al., 2005; revisado em Wortmann et al., 2010; Motta e Sampaio, 2011). Quanto ao mecanismo de ação da anfotericina, sabe-se que está principalmente relacionado à formação de poros na membrana do parasita, uma vez que atua substituindo esteróides, como o ergosterol, na bicamada lipídica. Essa interferência é capaz de alterar o balanço iônico da célula levando à sua destruição (Croft e Coombs, 2003; Neumann et al., 2010).

O uso da pentamidina, por sua vez, leva a quadros de elevada toxicidade com efeitos que incluem mialgia, náusea e hipotensão (Singh e Sivakumar, 2004). O uso da pentamidina é reservado apenas aos casos de falha terapêutica com antimoniais e anfotericina B. Contudo, sua eficácia na leishmaniose cutânea é questionável uma vez que seu índice de sucesso em estudos na América Latina parece variar de acordo com a região geográfica e a espécie do parasita (Soto-Mancipe et al., 1993; Lightburn et al., 2003; Andersen et al., 2005). A aplicação da pentamidina para leishmaniose visceral antroponótica na Índia já não é mais recomendada porque desencadeia efeitos colaterais bastante intensos já que as doses empregadas são mais altas e também devido à circulação de cepas de parasitas resistentes à droga (Thakur et al., 1991; Singh e Sivakumar, 2004). Trabalhos mostraram que o mecanismo de ação leishmanicida da pentamidina parece estar baseado no acúmulo da droga no parasita, o que levaria à sua associação ao DNA do cinetoplasto. Somado a isso, esta molécula parece desencadear o colapso do potencial de membrana mitocondrial (revisado em Bray et al., 2003).

Diversos estudos focaram seus objetivos na tentativa de encontrar terapias alternativas para o tratamento da leishmaniose. Dentre estas talvez a mais promissora refirase à utilização de derivados de lisofosfatidilcolina como a hexadecilfosfocolina (miltefosine), eficaz contra L. (L.) donovani (Achterberg e Gercken, 1987). Um primeiro ensaio clínico de fase II realizado em 1997 mostrou que a administração oral de miltefosine foi eficaz no tratamento 
de pacientes indianos com leishmaniose visceral (Sundar et al., 1998). Após uma série de resultados promissores em novos ensaios clínicos mostrando que miltefosine levou a taxas de cura entre 94 e 97\%, sua utilização foi aprovada para o tratamento da leishmaniose visceral na Índia e para outras manifestações da doença. Os principais efeitos colaterais associados são distúrbios gastrintestinais, mas a maior limitação do miltefosine é seu potencial teratogênico, particularidade que impede o uso em mulheres grávidas (Croft e Coombs, 2003; Singh e Sivakumar, 2004). Vale ressaltar que Pérez-Victoria e colaboradores demonstraram em 2003 a existência de linhagens de L. (L.) donovani resistentes ao miltefosine (Pérez-Victoria et al., 2003). Além disso, Soto et al. (2004) demonstraram que, apesar de bem tolerada, a aplicação de miltefosine em pacientes com leishmaniose cutânea não foi tão eficaz no tratamento tanto de infecções por L. (V.) braziliensis na Colômbia quanto por L. (V.) panamensis na Guatemala (Soto et al., 2004). Por outro lado, os resultados de um ensaio clínico recentemente publicado mostram que a utilização de miltefosine em pacientes do estado da Bahia infectados com $L$. (V.) braziliensis levou a taxas de cura superiores às obtidas pela administração de antimonial pentavalente (Machado et al., 2010).

Estudos apontam que o mecanismo de ação do miltefosine parece estar primeiramente relacionado à ação na membrana plasmática parasitária e posterior interferência na transdução de sinal, homeostase de cálcio e inibição da síntese de fosfatidilcolina e RNA (Croft e Coombs, 2003; Azzouz et al., 2005).

Uma segunda droga em fase de testes clínicos é a paromomicina (Croft et al., 2006), um antibiótico aminoglicosídico cuja atividade leishmanicida foi verificada inicialmente na década de 1960. Apesar da baixa biodisponibilidade oral da paromomicina, ensaios em Bihar, na Índia, demonstraram atividade promissora da droga em pacientes refratários aos antimoniais (Thakur et al., 2000). O uso injetável da droga levou a taxas de cura em torno de 80\% para pacientes com leishmaniose visceral no Quênia (Chunge et al., 1990). Entretanto, tais resultados parecem contraditórios quando comparados a resultados mais recentes que relataram eficácia parcial da paromomicina em formulações tópicas específicas ou associadas a antimoniais (Asilian et al., 2003; Armijos et al., 2004; Gonçalves et al., 2005; Iraji et al., 2005). São descritos como os principais efeitos colaterais da paromomicina a toxicidade para os rins e para o nervo auditivo (Singh e Slvakumar, 2004). A ação leishmanicida deste 
aminoglicosídeo parece estar relacionada à interferência na atividade mitocondrial do parasita, a partir da inibição da respiração celular e despolarização da membrana (Croft e Coombs, 2003; Croft et al., 2006).

Outras drogas tem sido utilizadas como alternativas para o tratamento da leishmaniose, incluindo os azóis, moléculas capazes de interferir na biossíntese de ergosterol do parasita; o alopurinol, um análogo de purinas; o imiquimod, um agente imunomodulador capaz de estimular a produção de óxido nítrico em macrófagos infectados pelo parasita; o sitamaquine, um análogo da primaquina com atividade leishmanicida, capaz de se acumular no parasita e interagir transitoriamente com sua membrana plasmática; além de técnicas baseadas em crioterapia e termoterapia diretamente aplicadas a lesões cutâneas (Croft et al., 2006; Singh e Sivakumar, 2004; Ameen, 2010; Coimbra et al., 2010). Existem alguns ensaios clínicos que avaliaram os índices de sucesso terapêutico destas drogas bem como de terapias alternativas, contudo, mostram-se muitas vezes controversos. Nota-se que para determinadas regiões e espécies de Leishmania existe algum progresso com o uso de novas formulações, ao passo que para outras áreas pode-se notar a ausência de respostas terapêuticas satisfatórias, representando assim um desafio para a incorporação de novos esquemas terapêuticos (SotoMancipe et al., 1993; Blum et al., 2004; Singh e Sivakumar, 2004; Wasunna et al., 2005; Ameen et al., 2010).

Dada a dificuldade de se obter resposta satisfatória a partir de monoterapias, emerge atualmente uma tendência mundial focada nos tratamentos combinados como alternativa para o tratamento tanto da leishmaniose cutânea como da visceral. Muitas são as suas vantagens, como o aumento na eficácia e tolerância com redução do período de tratamento e, portanto, maior adesão ao tratamento e redução nos custos; a possibilidade de drogas com estruturas químicas diferentes atuarem em alvos distintos do parasita, reduzindo a probabilidade de indução de resistência; além de maiores chances de sucesso na terapia de pacientes co-infectados por HIV/Leishmania (Modabber et al., 2007; van Griensven et al., 2010). Tal iniciativa tem levado ao planejamento e execução de diversos estudos clínicos em áreas endêmicas tanto para a forma visceral (revisado em van Griensven et al., 2010) como para a forma cutânea da leishmaniose (Miranda-Verástegui et al., 2005; Al-Mutairi et al., 2009; El-Sayed e Anwar, 2010). 


\subsection{Alternativas para o tratamento da leishmaniose - o caso do tamoxifeno}

Ao analisarmos o atual cenário da terapêutica da leishmaniose, é possível identificar a necessidade mandatória de pesquisa de novas drogas, com estrutura e mecanismos de ação distintos das utilizadas até o presente momento (Kayser et al., 2001). Inúmeros relatos na literatura demonstram o potencial leishmanicida de diversos compostos das mais diferentes classes químicas, provenientes de fontes como: a) estruturas vegetais; b) micro-organismos; c) organismos invertebrados; d) derivados de outras moléculas cuja atividade já foi estabelecida; e) medicamentos já disponíveis para diferentes doenças, entre outros (Handman et al., 2008; Kedzierski et al., 2009; Tempone et al., 2011). A maciça maioria dos trabalhos relata a ação destas moléculas em culturas de parasitas, mostrando eficácia contra formas promastigotas e amastigotas, mas nem sempre demonstrando a atividade para modelos in vivo de infecção por Leishmania. Ainda assim, é inegável a importância deste tipo de estudo visando à varredura e identificação de compostos alternativos que sirvam futuramente como fármacos anti-Leishmania ou mesmo como protótipos para a síntese de moléculas mais ativas.

Dentre um amplo espectro de fármacos que tem sido utilizados no tratamento de neoplasias humanas, destaca-se o tamoxifeno ([Z]-2-[4-(1,2-difenil-1-butenil)-fenóxi]-N,Ndimetiletanamina; Figura 2). Esse fármaco foi originalmente desenvolvido como um contraceptivo de uso oral cujo potencial antiestrogênico foi logo reconhecido, tornando seu uso clínico contra o câncer de mama metastático muito bem estabelecido desde a década de 1970 (Harper e Walpole, 1966; Goldstein, 1999). Nos últimos 25 anos, tamoxifeno tem sido utilizado em todos os estágios do câncer de mama, embora sua eficácia seja mais significativa para inibição de tumores estrógeno-dependentes (revisado em Morello et al., 2002).

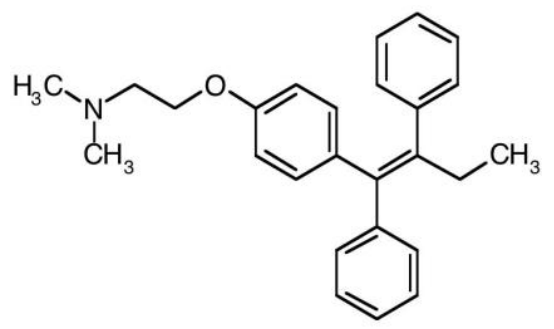

Figura 2. Estrutura química da molécula de tamoxifeno. 
O mecanismo de ação desse fármaco está relacionado à sua capacidade de se ligar (em concentrações nanomolares) competitivamente ao receptor de estrógeno no tecido mamário tumoral. A partir daí, forma um complexo capaz de inibir o domínio de ativação AF2 do receptor, o que em última instância leva à inibição de transcrição a partir de promotores responsivos a estrógeno, acarretando a parada do crescimento celular. Logo, o tamoxifeno é um forte antagonista do estrógeno na mama. Entretanto, pode atuar como agonista fraco em diferentes tecidos como o endometrial e ósseo, que apresentam majoritariamente ativação via AF1 em relação ao domínio AF2 (Harvey et al., 1999; revisado em Ali e Coombes, 2002). Tal efeito é de extrema relevância para se estabelecer o período ideal de tratamento com tamoxifeno, uma vez que intervalos prolongados de uso do fármaco parecem estar relacionados à indução de eventos tromboembólicos e aumento do risco de desenvolvimento de câncer endometrial (Bernstein, 1999; Jordan, 2008).

Graças a essa plasticidade, o tamoxifeno é classicamente descrito como um modulador seletivo de receptor de estrógeno (SERM) (Muchmore, 2000; Taras et al., 2001). Todavia, seu mecanismo de ação na terapia e prevenção do câncer de mama ainda não está completamente elucidado.

Diversos estudos apresentados nas últimas décadas demonstraram que o tamoxifeno exibe uma série de efeitos tanto in vitro como in vivo que não podem ser explicados por meio de sua interação com o receptor estrogênico. Normalmente estes efeitos são verificados a partir de concentrações na faixa de micromolar e parecem estar relacionados à atividade de tamoxifeno para outros tipos de câncer e casos de tumores de mama não-responsivos ao estrógeno (revisado em Gelmann, 1997). Estes efeitos incluem a:

- inibição na síntese de isoprenoides como o dolicol (Santa Cruz et al., 1985),

- interação com membranas celulares (Wiseman et al., 1990; Custódio et al., 1994),

- interferência no metabolismo de esfingolipídios (Cabot et al., 1996; Lavie et al., 1997),

- inibição da acidificação de organelas intracelulares (Altan et al., 1998, 1999; Chen et al., 1999), 
- inibição de canais de cloro e cálcio e o aumento da suscetibilidade a drogas em linhagens tumorais multi-resistentes (Lavie et al., 1997; Altan et al., 1999) e

- modulação de diversas proteínas sinalizadoras, ligação a calmodulinas, caspases e proteínas quinases (Mandlekar e Kong, 2001).

A ativação ou inibição de uma ou mais dessas vias de sinalização leva ao desencadeamento de apoptose, podendo esta ser mediada por estresse oxidativo, transição de permeabilidade mitocondrial, acúmulo de ceramidas ou mudanças na fluidez da membrana celular (revisado em Mandlekar e Kong, 2001).

É sabido que a forma amastigota de Leishmania localiza-se obrigatoriamente no vacúolo fagolisossômico de macrófagos do hospedeiro vertebrado, sendo este um ambiente tipicamente ácido. Mukkada e colaboradores (1985) verificaram que a atividade metabólica dos amastigotas é ótima para valores de pH próximos a 5,0 (Mukkada et al., 1985). Dessa forma, foi razoável supor que tamoxifeno seria capaz de alterar a acidez de vacúolos macrofágicos contendo amastigotas e que, portanto, poderia ser testado como uma agente anti-Leishmania. A interferência nos mecanismos intrínsecos de manutenção do pH poderia promover distúrbios na multiplicação do parasita no interior desses vacúolos. Além disso, o fato deste fármaco já possuir segurança clínica muito bem estabelecida fortaleceu nosso interesse em determinar seu potencial leishmanicida.

A partir destes fundamentos foi avaliada preliminarmente a atividade do tamoxifeno contra culturas de promastigotas de L. (L.) amazonensis e, com base em resultados promissores, foi proposto como principal objetivo desta Tese a caracterização aprofundada da atividade deste fármaco contra Leishmania, conforme detalhado no item a seguir. 
2 OBJETIVOS 


\subsection{Objetivo geral}

Avaliar a atividade de tamoxifeno contra diferentes espécies de Leishmania in vitro e in vivo e identificar possível(is) mecanismo(s) de ação que justifiquem sua atividade leishmanicida.

\subsection{Objetivos específicos}

No que diz respeito à atividade do tamoxifeno, propõe-se:

- avaliar sua eficácia contra culturas de promastigotas, amastigotas purificados de lesão e macrófagos contendo amastigotas de diferentes espécies de Leishmania

- determinar o efeito leishmanicida deste fármaco a partir de diferentes vias de administração em modelos animais infectados experimentalmente

- realizar testes com diferentes SERMS utilizados clinicamente (toremifeno e raloxifeno), na tentativa de se estabelecer o efeito leishmanicida dos mesmos.

Quanto à investigação dos mecanismos de ação do tamoxifeno, pretende-se avaliar:

- a modulação da alcalinização de vacúolos fagolisossômicos contendo parasitas do gênero Leishmania, de modo a averiguar os efeitos da mudança de $\mathrm{pH}$ exercida pelo tamoxifeno na sobrevida da forma amastigota do parasita

- sua interferência no metabolismo de esfingolipídios em Leishmania

- sua interferência no metabolismo de isoprenoides de Leishmania

- possíveis alterações ultra-estruturais em Leishmania induzidas pelo tamoxifeno, por microscopia ótica e eletrônica de transmissão. 
3 MATERIAIS E MÉTODOS 


\subsection{Culturas de parasitas do gênero Leishmania}

Promastigotas de L. (L.) amazonensis (MHOM/BR/1973/M2269), L. (V.) braziliensis (MHOM/BR/1975/M2903), L. (L.) chagasi (MHOM/BR/1974/M2682), L. (L.) donovani (LD15/MHOM/SD/O0), L. (L.) major (MHOM/IL/1981/Friedlin) e L. (L.) mexicana (MNYC/BZ/62/M379), bem como de isolados de pacientes identificados como L. (L.) amazonensis, L. (V.) braziliensis e L. (L.) chagasi foram cultivados a $25^{\circ} \mathrm{C}$ em meio 199 (Gibco$B R L$, Invitrogen) preparado diluindo-se o pó em água destilada e adicionando-se HEPES 40 $\mathrm{mM}, \mathrm{pH} 7,4$, adenina $0,1 \mathrm{mM}, 0,005 \%$ de hemina com suplemento de 10 ou $20 \%$ de soro fetal bovino (SFB; Invitrogen). Em culturas de L. (V.) braziliensis e L. (L.) chagasi também foram adicionados $2 \%$ de urina humana masculina estéril. Os repiques foram realizados semanalmente e as culturas mantidas por cerca de 10 passagens.

Para a obtenção de parasitas de lesão foram sacrificados camundongos BALB/C previamente infectados com $1 \times 10^{6}$ promastigotas de L. (L.) amazonensis no coxim plantar traseiro (Uliana et al., 1991). O material da lesão foi retirado e macerado em homogeneizador de vidro com PBS gelado $\left(\mathrm{NaH}_{2} \mathrm{PO}_{4} 2,6 \mathrm{mM}, \mathrm{Na}_{2} \mathrm{HPO}_{4} 7,4 \mathrm{mM}, \mathrm{NaCl} 14 \mathrm{mM}, \mathrm{pH}\right.$ 7.2). O produto foi lavado em PBS para posterior separação dos debris celulares por centrifugação a 60 x g por 8 min. O sobrenadante foi a seguir lavado 3 vezes com PBS estéril, seguido de três centrifugações a $600 \times \mathrm{g}$ por $10 \mathrm{~min}$ a $4{ }^{\circ} \mathrm{C}$. Os amastigotas foram mantidos in vitro em meio RPMI-1640 completo (Invitrogen). Ao pó diluído em água foi adicionado ß-mercaptoetanol 2 $\mu \mathrm{M}, \mathrm{HEPES} 25 \mathrm{mM}, \mathrm{NaHCO}_{3} 2,7 \mathrm{mM}$ e $10 \%$ de SFB. As culturas foram mantidas em estufa a 33 ${ }^{\circ} \mathrm{C}$ com atmosfera de $5 \% \mathrm{CO}_{2}$. Também foram acrescentados ao meio os antibióticos ampicilina $(100 \mu \mathrm{g} / \mathrm{mL})$ e gentamicina $(50 \mathrm{mg} / \mathrm{mL})$. 


\subsection{Culturas de Trypanosoma cruzi}

Em nosso laboratório foram cultivados, com o auxílio da Dra. Anahí Magdaleno e Elizabeth Pral, pertencentes ao laboratório do Prof. Dr. Ariel Silber (ICB-USP), epimastigotas de T. cruzi cepa CL-Brener (Brener e Chiari, 1963) em meio LIT suplementado com $10 \%$ de SFB a $25{ }^{\circ} \mathrm{C}$ (Camargo, 1964). Formas intracelulares de T. cruzi cepa CL-Brener foram obtidas a partir da infecção de células LLC-MK2 (rim de macaco Rhesus) com parasitas de fase estacionária de culturas em meio LIT numa proporção de 50 parasitas/célula. As culturas foram mantidas a $34{ }^{\circ} \mathrm{C}$ e atmosfera de $5 \% \mathrm{CO}_{2}$ em meio RPMI-1640 completo suplementado com $2 \%$ de SFB por 24 h, com lavagens e adição de meio fresco em intervalos de $24 \mathrm{~h}$. Formas tripomastigotas e epimastigotas das cepas $\mathrm{Y}$, beznidazol sensível e resistente (Silva e Nussenzweig, 1953; Murta e Romanha, 1988) foram cultivadas no laboratório do Prof. Dr. Alvaro Romanha (Fundação Oswaldo Cruz, Belo Horizonte, MG) como descrito no ANEXO E.

\subsection{Drogas}

Soluções estoque de $10 \mathrm{mM}$ de tamoxifeno puro, 4-hidróxi-tamoxifeno e hidrocloreto de raloxifeno (Sigma-Aldrich) foram preparadas a cada 30-45 dias diluindo-se o pó em etanol e, no caso de raloxifeno, em metanol. Tamoxifeno e 4-hidróxi-tamoxifeno foram armazenados a $-20{ }^{\circ} \mathrm{C}$ e raloxifeno a $4{ }^{\circ} \mathrm{C}$. Citrato de tamoxifeno (Sigma-Aldrich) foi diluído com o auxílio de um aparelho sonicador em solução salina $(\mathrm{NaCl} 150 \mathrm{mM})$ a cada dois dias para a administração em animais de experimentação. As alíquotas foram armazenadas a $4^{\circ} \mathrm{C}$. Citrato de toremifeno foi adquirido de Sigma-Aldrich e soluções estoque a $10 \mathrm{mM}$ foram preparadas em PBS e armazenadas a $4{ }^{\circ} \mathrm{C}$. Glucantime ${ }^{\circledR}$ (antimoniato de meglumina; sol. inj. $300 \mathrm{mg} / \mathrm{mL}$ ) foi gentilmente cedido por Sanofi-Aventis e armazenado a $4{ }^{\circ} \mathrm{C}$. Desoxicolato de anfotericina (Sigma-Aldrich) foi solubilizado em água bidestilada estéril (10 mM) e armazenado a $-20^{\circ} \mathrm{C} .0$ terpeno limoneno (Sigma-Aldrich), utilizado a $2 \%$ em solução etanólica aplicada em lesões de camundongos BALB/c, foi preparado a cada 2 dias e armazenado a $4{ }^{\circ} \mathrm{C}$. 


\subsection{Ensaios de inibição de crescimento de promastigotas e amastigotas de Leishmania}

Culturas de parasitas com inóculo entre 1 e $5 \times 10^{6}$ células foram tratadas com diversas concentrações de diferentes drogas por $24 \mathrm{~h}$ em placas de 24 ou 96 poços. A viabilidade das células foi avaliada utilizando-se o teste do MTT (brometo de 3-(4,5-dimetitiazol-2-il)-2,5difenil-2H tetrazólio; Sigma-Aldrich) ou a partir da contagem de células viáveis em câmara de Neubauer. Culturas mantidas em meio sem droga e incubadas na presença do diluente da droga serviram como controles experimentais. Os resultados dos testes de inibição do crescimento foram expressos calculando-se a porcentagem de sobrevivência dos parasitas após o tratamento em relação ao grupo controle que não recebeu a droga. Calcularam-se também os valores referentes às doses inibitórias para 50 e $90 \%$ das culturas $\left({ } C_{50}\right.$ e $I C_{90}$, respectivamente) a partir do software OriginLab ${ }^{\circledR}$ _DATA ANALYSIS AND GRAPHING (Origin $\left.7.5^{\circledR}\right)$. Os experimentos foram realizados em triplicata, sendo cada um repetido pelo menos duas vezes.

\subsection{Teste do MTT}

O ensaio do MTT está muito bem estabelecido para determinação de viabilidade em diferentes modelos celulares. Trata-se de um método simples, de baixo custo e aplicável para testes de screening de drogas em larga escala (revisado em Fumarola et al., 2004). Basicamente, o método para avaliação em placas de 24 poços iniciou-se com a passagem das

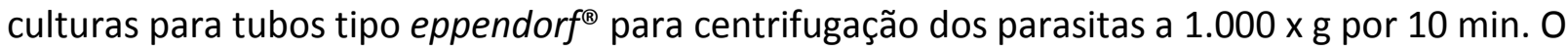
sobrenadante foi desprezado e as células lavadas 2 vezes com $1 \mathrm{~mL}$ de tampão $A(\mathrm{NaCl} 116$ $\mathrm{mM}, \mathrm{KCl} 5,4 \mathrm{mM}, \mathrm{MgSO}_{4}$ 0,8 mM, glicose 5,5 mM e MOPS $10 \mathrm{mM}$ ). Ao sedimento foi adicionado $100 \mu \mathrm{L}$ de tampão A e $20 \mu \mathrm{L}$ de MTT (5 mg do pó por $\mathrm{mL}$ de Tampão A) e incubado 
por $2 \mathrm{~h}$ a $25^{\circ} \mathrm{C}$ (para promastigotas) e $33^{\circ} \mathrm{C}$ (para amastigotas) para posterior interrupção da reação com adição de $200 \mu \mathrm{L}$ de SDS $10 \%$ (dodecil sulfato de sódio). A leitura da absorbância foi realizada em espectrofotômetro de placa (LABSYSTEMS, Multiskan EX) medindo-se a absorbância a $595 \mathrm{~nm}$, sendo de $655 \mathrm{~nm}$ o comprimento de onda utilizado como referência (Moreira et al., 1996). Os valores de densidade ótica (DO) foram convertidos a porcentagens em relação ao controle não tratado (equivalente a 100\% de viabilidade celular) para posterior determinação dos valores de $\mathrm{IC}_{50}$ e I $\mathrm{I}_{90}$.

Para ensaios em placas de 96 poços foi utilizada a metodologia adaptada por nosso grupo recentemente (Zauli-Nascimento et al., 2010). Para isso, culturas incubadas diretamente nas placas de 96 poços receberam $30 \mu \mathrm{L}$ de MTT. Após $2 \mathrm{~h}$ a $25^{\circ} \mathrm{C}$ (para promastigotas) e $33{ }^{\circ} \mathrm{C}$ (para amastigotas), foi adicionado $50 \mu \mathrm{L}$ de SDS $20 \%$ por poço e a leitura das DOs foi realizada conforme descrito acima.

\subsection{Obtenção de macrófagos e ensaios de inibição de infecção in vitro}

Macrófagos residentes de peritônio de camundongos BALB/c foram obtidos após 3 lavagens sucessivas da cavidade peritoneal dos animais com $5 \mathrm{~mL}$ de meio RPMI-1640 completo suplementado com $10 \%$ de SFB e gelado. O procedimento foi repetido 3 vezes. 0 conteúdo foi transferido para tubo plástico tipo FALCON ${ }^{\circledR}$ estéril mantido em gelo. Após lavagem a $300 \times$ g por $10 \mathrm{~min}$, as células foram contadas em câmara de Neubauer e plaqueadas em lamínulas de vidro em placas de 24 poços por $24 \mathrm{~h}$ em estufa a $37{ }^{\circ} \mathrm{C}$ com atmosfera de $5 \% \mathrm{CO}_{2}$. Após este período, o meio foi retirado e a cultura lavada com RPMI sem soro aquecido para subseqüente utilização em experimentos de infecção.

Para a obtenção de macrófagos derivados de medula óssea de camundongos BALB/c foi utilizado o protocolo descrito por Zamboni e Rabinovitch em 2003, para o qual se sacrificaram camundongos por asfixia em câmara de $\mathrm{CO}_{2}$ para excisão das epífises e extração de fêmur. Cada fêmur teve seu conteúdo medular lavado com uma seringa de $5 \mathrm{~mL}$ e agulha $21 \mathrm{G}$ com meio RPMI suplementado com $10 \%$ de SFB e $20 \%$ de sobrenadante de culturas de 
fibroblastos $L 929$ (meio R2030). O conteúdo foi mantido em placas de Petri de poliestireno (Optilux ${ }^{\mathrm{TM}}$ ), um fêmur por placa, por 7 dias em estufa a $37^{\circ} \mathrm{C}$ com atmosfera de $5 \% \mathrm{CO}_{2}$. No quarto dia foi acrescentado mais $10 \mathrm{~mL}$ de meio R2030 por placa. Ao final do período o meio foi descartado e às placas foi adicionado $5 \mathrm{~mL}$ de meio RPMI sem soro gelado. As placas foram incubadas em gelo por $15 \mathrm{~min}$. Cell scraper (Corning Inc.) foi utilizado para descolar os macrófagos diferenciados das placas que foram centrifugados a $60 \times \mathrm{g}$ por $10 \min$ a $4{ }^{\circ} \mathrm{C}$ e ressuspensos em meio R105 (meio RPMI completo contendo $10 \%$ de SFB e $5 \%$ de sobrenadante de culturas de fibroblastos L929). A seguir as células foram contadas em câmara de Neubauer e plaqueadas em lamínulas de vidro em placas de 24 poços e mantidas em estufa a $37{ }^{\circ} \mathrm{C}$ com atmosfera de $5 \% \mathrm{CO}_{2}$ para subseqüente utilização em experimentos de infecção (Zamboni e Rabinovitch, 2003). Os macrófagos residentes de peritônio ou derivados de medula óssea foram infectados com amastigotas ou promastigotas de Leishmania em proporções conhecidas. Após 2 a $3 \mathrm{~h}$ de incubação a $33^{\circ} \mathrm{C}$ em estufa com atmosfera de $5 \%$ de $\mathrm{CO}_{2}$, as culturas foram lavadas 3 vezes com RPMI sem soro aquecido e, a seguir, incubadas com RPMI fresco ou R105 (para macrófagos derivados de medula). As drogas foram acrescentadas em concentrações crescentes sendo que tamoxifeno, raloxifeno e desoxicolato de anfotericina foram incubados por $48 \mathrm{~h}$ enquanto que as culturas tratadas com Glucantime ${ }^{\circledR}$ foram incubadas com a droga por 3 dias e lavadas para adição de droga fresca e re-incubação por mais 2 dias. Após o período de incubação as células foram lavadas com PBS $1 X$ aquecido e fixadas com metanol puro para serem coradas com conjunto de corantes INSTANT PROV ${ }^{\circledR}$ (NewProv ${ }^{\circledR}$, Brasil). As lamínulas foram observadas por microscopia ótica para contagem das porcentagens de infecção e posterior determinação das taxas de infecção e dos valores de $I_{50}$ e $\mathrm{IC}_{90}$, conforme descrito anteriormente.

\subsection{Ensaios de citotoxicidade}

Diversas culturas celulares foram utilizadas em ensaios de citotoxicidade para diferentes compostos, sendo elas: células macrofágicas (linhagem J774 A.1, gentilmente 
cedida pela Profa. Dra. Sonia Jancar (ICB-USP), residentes de peritônio ou obtidas a partir de medula óssea de camundongos $B A L B / C$ ), fibroblastos de prepúcio humano (HFF), de epitélio de rim de macaco Rhesus (LLCMK-2), de ovário de hamster chinês (CHO-K1) e de carcinoma de laringe (HEp-2). As células macrofágicas foram cultivadas conforme descrito previamente e as demais linhagens foram cultivadas em meio RPMI completo a $37{ }^{\circ} \mathrm{C}$ com atmosfera de $5 \%$ $\mathrm{CO}_{2}$. Os ensaios de citotoxicidade foram realizados em placas de 24 poços contendo 1 a $5 \mathrm{x}$ $10^{6}$ células por poço. Após a adição das diferentes drogas em concentrações crescentes por 24 $h$, as culturas foram lavadas com PBS $1 \mathrm{X}$ aquecido e a seguir incubadas com MTT em Tampão A (60 $\mu \mathrm{L}$ de MTT a $5 \mathrm{mg} / \mathrm{mL}$ e $180 \mu \mathrm{L}$ de Tampão A) por 3-5 h a $37^{\circ} \mathrm{C}$. Adicionou-se $150 \mu \mathrm{L}$ de SDS $20 \%$ por poço e seu conteúdo foi vigorosamente homogeneizado. A leitura da DO foi realizada conforme descrito acima. Os valores de concentração citotóxica de cada droga para $50 \%$ das culturas $\left(\mathrm{CC}_{50}\right)$ foram estabelecidos da mesma forma que os valores de $\mathrm{IC}_{50}$ para culturas de parasitas.

\subsection{Ensaios in vivo}

Fêmeas de camundongos BALB/c com 30 a 45 dias foram obtidas do Biotério de Experimentação Animal do Departamento de Parasitologia (ICB/USP) para utilização em nossos experimentos in vivo. Todos os ensaios foram realizados de acordo com as normas adotadas pelo Colégio Brasileiro de Experimentação Animal (COBEA) e aprovados pela Comissão de Ética em Experimentação Animal (CEEA) do Instituto de Ciências Biomédicas da USP. Basicamente os grupos consistiam de 5 a 6 animais por gaiola com oferta constante de ração e água estéreis. Os camundongos foram inoculados com $1 \times 10^{6}$ amastigotas ou $5 \times 10^{6}$ promastigotas de L. (L.) amazonensis na base da cauda. Diversos grupos receberam tratamentos por 15 ou 21 dias com variadas drogas e formulações por diferentes vias de administração (oral, tópica ou intraperitoneal) sempre se iniciando o tratamento 30 a 45 dias após a infecção, quando já havia se dado o estabelecimento da lesão por vezes com presença de edema e mais raramente de reduzidas úlceras. Para o tratamento com tamoxifeno por via 
intraperitoneal, os animais tratados receberam injeção intraperitoneal de 30,4 mg de citrato de tamoxifeno/kg/dia (equivalente a $20 \mathrm{mg} / \mathrm{kg} / \mathrm{dia}$ de tamoxifeno) ou $20 \mathrm{mg} / \mathrm{kg} / \mathrm{dia}$ de antimoniato de meglumine (Glucantime ${ }^{\circledR}$ ) por 15 dias. A progressão da doença foi avaliada semanalmente medindo-se a espessura da base da cauda, mais especificamente no sítio da lesão (nas direções vertical e horizontal) e a área ulcerada $\left(\mathrm{mm}^{2}\right)$. As medidas foram realizadas com paquímetro (Mitutoyo Corp., Japão). A carga parasitária foi avaliada pelo método da diluição limitante detalhado a seguir. O peso corpóreo e uterino de cada animal também foi avaliado como parâmetro de toxicidade. Análises histopatológicas dos úteros de animais tratados e não tratados foram realizadas no laboratório da Profa. Dra. Telma Zorn (ICB/USP). Tratamentos por via tópica e oral também foram conduzidos com animais infectados conforme descrito anteriormente e seguiram o seguinte esquema: $25 \mathrm{mg} / \mathrm{kg} / \mathrm{dia}$ de tamoxifeno puro via tópica; 30,4 mg de citrato de tamoxifeno via oral; 30,4 mg/kg/dia de citrato de tamoxifeno via oral e $12,5 \mathrm{mg} / \mathrm{kg} /$ dia de tamoxifeno puro via tópica. As aplicações tópicas de soluções etanólicas de tamoxifeno puro ou limoneno $2 \%$ foram realizadas com pipeta Gilson ${ }^{\circledR}$ para volumes de 4 a $10 \mu \mathrm{L}$ por lesão. A administração oral foi conduzida com seringa metálica de ponta curva para gavagem com a qual se aplicava 100 a $200 \mu \mathrm{L}$ de citrato de tamoxifeno diretamente no esôfago de cada animal. Grupos de animais também foram tratados com $40 \mathrm{mg} / \mathrm{kg} / \mathrm{dia}$ de raloxifeno por via intraperitoneal pelo período de 15 dias.

Experimentos foram conduzidos também com fêmeas de camundongos BALB/C inoculados com $1 \times 10^{5}$ promastigotas de L. (V.) braziliensis MHOM/BR/01/BA no pavilhão auricular esquerdo. O tratamento intraperitoneal iniciou-se 21 dias após o inóculo. Camundongos receberam citrato de tamoxifeno ou Glucantime ${ }^{\circledR}(20 \mathrm{mg} / \mathrm{kg} / \mathrm{dia})$ por 15 dias ou desoxicolato de anfotericina $(0,5 \mathrm{mg} / \mathrm{kg} / \mathrm{dia})$ por 12 dias alternados. As lesões foram acompanhadas quanto à espessura, sempre em comparação com a orelha direita não infectada e, ao final do tratamento, foi determinada a carga parasitária por diluição limitante.

O último modelo de infecção adotado foi o de leishmaniose visceral em hamsters. Fêmeas e machos de hamsters dourados infectados com $1 \times 10^{8}$ amastigotas de $L$. (L.) chagasi (MHOM/BR/1974/M2682) foram cedidos pela Profa. Dra. Clara Barbiéri (UNIFESP). Os animais receberam salina $(\mathrm{NaCl} 150 \mathrm{mM}), 20 \mathrm{mg} / \mathrm{kg} / \mathrm{dia}$ de tamoxifeno ou Glucantime ${ }^{\circledR}$ por 2 semanas consecutivas. Após esse período foi avaliada a carga parasitária no fígado e baço dos animais e 
acompanhado o período de sobrevivência e ganho de peso dos mesmos. Todos os experimentos utilizando animais foram repetidos pelo menos 2 vezes, com $n=5-7$ animais/grupo por experimento. Os dados de progressão de lesão foram analisados estatisticamente utilizando-se o teste não-paramétrico Mann-Whitney (GraphPad Prism 5 software).

Os ensaios in vivo para avaliação da atividade de tamoxifeno em infecções agudas por T. cruzi foram realizados conforme descrito por Filardi e Brener (Filardi e Brener, 1987). Camundongos BALB/c e suíços, tanto machos como fêmeas (8-10 por grupo) foram infectados intraperitonealmente com 500 ou 5.000 tripomastigotas de T. cruzi cepa Y. No segundo (para camundongos BALB/c) ou quarto (para camundongos suíços) dia de infecção, o tratamento foi iniciado com citrato de tamoxifeno $(10,25$ ou $50 \mathrm{mg} / \mathrm{kg} /$ dia do equivalente em tamoxifeno) ou benznidazol (Rochagan, Roche Co.) (100 mg/kg/dia) pelo período de 15 a 20 dias. A parasitemia foi avaliada a cada dois dias a partir do segundo dia de infecção por contagem de formas tripomastigotas em $5 \mu \mathrm{L}$ de sangue da via caudal. Além disso, a sobrevivência dos animais foi monitorada por 1 mês.

\subsection{Quantificação de parasitas - Diluição Limitante e imprints}

Animais de cada grupo nos diferentes experimentos foram aleatoriamente sacrificados para remoção dos tecidos das lesões na base da cauda e orelha de camundongos ou do baço de hamsters infectados. Tecidos e órgãos foram isolados e homogeneizados com $1 \mathrm{~mL}$ de PBS. O conteúdo foi armazenado em gelo para posterior centrifugação a $60 \times \mathrm{g}$ por 8 min e recolhimento do sobrenadante. Em seguida, foi realizada nova centrifugação a $600 \times$ g por 10 min para ressuspensão do sedimento em $2 \mathrm{~mL}$ de meio 199. As células foram contadas em câmara de Neubauer e alíquotas de $150 \mu \mathrm{L}$ distribuídas no primeiro poço de uma placa de 96 poços contendo $50 \mu \mathrm{L}$ de meio 199. Foram realizadas diluições sucessivas de $20 \mu \mathrm{L}$ até o 12 을 poço (Afonso e Scott, 1993) sendo que todos os poços continham $180 \mu \mathrm{L}$ do mesmo meio. As placas foram incubadas por 7 dias a $25{ }^{\circ} \mathrm{C}$, para posterior verificação de crescimento das 
culturas e quantificação de parasitas viáveis (Lima et al., 1997). A análise estatística dos resultados de diluição limitante foi feita utilizando-se o programa ELIDA (ELIDA Software Carl Tarswel). As diferenças foram consideradas significativas para valores de $P<0,05$. A carga parasitária do fígado de hamsters infectados e tratados ou não foi determinada por inprint direto dos órgãos removidos dos animais sacrificados em lâminas de vidro para posterior coloração com Instant Prov $^{\circledR}$ (Brasil). Para isso foi determinada a carga parasitária a partir da contagem de amastigotas por microscopia ótica para o cálculo das unidades de LeishmanDonovan (LDU) utilizando-se a seguinte equação: número de amastigotas/1.000 células x peso do órgão (g). As diferenças foram consideradas significativas para valores de $P<0,05$.

\subsection{Avaliação macroscópica}

Imagens de animais ao longo dos tratamentos foram registradas com câmera fotográfica digital Sony CyberShot 7.2M.

\subsection{Preparação de lipossomos}

Lipossomos multilamelares foram preparados conforme descrito por Bathia et al. (2004) para incorporação de tamoxifeno e posterior utilização em ensaios in vivo. Fases lipídicas foram preparadas dissolvendo-se quantidades apropriadas de fosfatidilcolina, ergosterol, colesterol e tamoxifeno em clorofórmio:metanol (2:1, v/v) em agitação constante por $5 \mathrm{~min}$. A mistura de solventes foi removida da fase lipídica em rota-evaporador a $45{ }^{\circ} \mathrm{C}$ para obtenção de um filme lipídico. O frasco contendo o filme foi mantido por $24 \mathrm{~h}$ em repouso e logo após hidratado com solução salina $(150 \mathrm{mM} \mathrm{NaCl})$ a $60^{\circ} \mathrm{C}$ por $1 \mathrm{~h}$. O frasco foi mantido por 2-3 $\mathrm{h}$ a temperatura ambiente para permitir hidratação completa do filme lipídico. Para obtenção dos lipossomos, a mistura total foi submetida à separação em coluna 
Sephadex G-50 (GE Healthcare Life Sciences) e posteriormente centrifugada a 1000 x g por 3 min. Amostras de cada fração foram observadas entre lâmina e lamínula no microscópio ótico. Alíquotas foram dissolvidas em clorofórmio:metanol $(2: 1, \mathrm{v} / \mathrm{v})$ e analisadas espectrofotometricamente para se estimar o conteúdo de tamoxifeno a $\lambda_{\text {máx }}$ de $274 \mathrm{~nm}$. Lipossomos sem tamoxifeno foram preparados da mesma forma. As preparações obtidas foram mantidas a $4{ }^{\circ} \mathrm{C}$ (Bathia et al., 2004) e utilizadas em administração intraperitoneal nos animais de experimentação.

\subsection{Quantificação de óxido nítrico (NO)}

Para determinar a dosagem de NO em sobrenadantes de culturas celulares, foi utilizada a Reação de Griess, pela qual se quantifica os níveis de nitrito - produto de degradação de NO - liberado de culturas de células (Ding et al., 1988). As células macrofágicas foram cultivadas em placas de 24 poços contendo lamínulas de $13 \mathrm{~mm}$ de diâmetro para infecção com parasitas conforme descrito anteriormente. Após tempos de tratamento de 2 , 24 e 48 h com tamoxifeno, o sobrenadante de cada poço foi congelado para a realização da Reação de Griess. Para a quantificação de NO, foi adicionado $50 \mu \mathrm{L}$ de sobrenadante das culturas por poço de uma placa de 96 poços contendo $100 \mu \mathrm{L}$ do reagente de Griess (solução A: sulfanilamida $1 \%$ em água e solução B: NAP em $5 \%$ de $\left.\mathrm{H}_{3} \mathrm{PO}_{4}\right)(\mathrm{v} / \mathrm{v})$, incubando-se a reação por 10 min a temperatura ambiente. A determinação da concentração de nitrito foi feita com base em curva padrão determinada a partir de concentrações conhecidas de $\mathrm{NaNO}_{3}$ (concentração inicial de $100 \mu \mathrm{M}$ ). A leitura das DOs foi realizada em espectrofotômetro de placa (Labsystems, Multiskan EX) com filtro de $550 \mathrm{~nm}$. 


\subsection{Eletroforese em gel de poliacrilamida contendo SDS (SDS-PAGE) e Western blot}

Aproximadamente $2 \times 10^{6}$ macrófagos derivados de medula óssea de camundongos BALB/c foram cultivados por poço em placas de 6 poços (BD Biosciences) na ausência ou na presença de LPS (10 ng/mL; Sigma-Aldrich) e interferon-gama (100 U/mL; Sigma-Aldrich) por 3h. Após este período, as células foram infectadas com amastigotas de $L$. (L.) amazonensis (5 parasitas por macrófago) por 1h. A seguir as infecções lavadas com PBS 1X aquecido foram incubadas com 15 ou $30 \mu \mathrm{M}$ de tamoxifeno por 3h. Extratos totais de proteínas foram obtidos adicionando-se $300 \mu \mathrm{L}$ do tampão de lise (Tris 25 mM, pH 7,4, SDS 1\%, NaCl 150 mM, EDTA 1 $\mathrm{mM}$ contendo $50 \mu \mathrm{L} / \mathrm{mL}$ do coquetel de inibidores de proteases P8340, Sigma-Aldrich) por poço para posterior descolamento das células com cell scraper. Alíquotas de $5 \mu \mathrm{L}$ foram utilizadas para quantificação de proteínas totais com BCA Protein Assay kit (Pierce). As proteínas foram separadas por eletroforese em gel de poliacrilamida 12\% (acrilamida 29\% e metilenobisacrilamida 1\%) na presença de SDS 0,01\% (Laemmli, 1970). A separação foi feita em cubas de eletroforese Mini-Protean (BioRad) em tampão Tris-glicina pH 8,3 (Tris 0,025 M, pH 8,3, glicina $0,19 \mathrm{M}$ e SDS 0,01\%) por $16 \mathrm{~h}$ a $18 \mathrm{~V}$ a temperatura ambiente. Como marcador de peso molecular foi utilizado o padrão PageRuler ${ }^{\mathrm{TM}}$ Prestained Protein Ladder (Fermentas). As proteínas foram transferidas para membranas de nitrocelulose (Hybond $\mathrm{ECL}$ ), utilizando-se tampão de transferência (Tris 48 mM, glicina 39 mM e 20\% de metanol) em cuba (Bio-Rad) por $3 \mathrm{~h}$ a 80V. A seguir as membranas foram lavadas com TBST (Tris $10 \mathrm{mM}, \mathrm{pH}$ 8,0, $\mathrm{NaCl} 150$ mM, Tween 20 0,1\%) e incubadas com TBST contendo 5\% leite desnatado em pó (Molico, Nestlé ${ }^{\circledR}$ ) por $1 \mathrm{~h}$ a temperatura ambiente. Para detecção da proteína iNOS foi utilizado o anticorpo anti-iNOS (Sigma-Aldrich) na diluição 1:10.000. No caso da detecção de actina foi utilizado o anticorpo anti- $\alpha$-actina (Sigma-Aldrich) na diluição de 1:5.000. Os anticorpos primários foram incubados por $1 \mathrm{~h}$ em TBST-3\% leite desnatado em pó. As membranas foram a seguir lavadas 3 vezes por 15 min com TBST para posterior incubação com o anticorpo secundário apropriado conjugado a peroxidase em TBST-3\% leite desnatado em pó por $1 \mathrm{~h}$ a temperatura ambiente. As membranas foram lavadas com TBST 3 vezes por 15 min e ao final, foi adicionado o substrato quimioluminescente (SuperSignal West Pico Chemiluminiscent 
Substrate, Pierce), levando-se em conta que para cada $\mathrm{cm}^{2}$ da membrana foi aplicado $0,1 \mathrm{~mL}$ da solução, deixando-se incubar por 5 min protegido de luz. Transcorrido esse tempo, foi removido o excesso e a membrana foi exposta ao filme Hyperfilm ${ }^{\text {TM }}$ ECL (GE Healthcare Life Sciences) para posterior revelação e fixação. Os ensaios de Western Blot para deteç̧ão de iNOS e actina foram realizados no Laboratório da Profa. Dra. Norma Andrews, da Universidade de Maryland, Estados Unidos.

\subsection{Ensaios para avaliação da alteração do pH de vacúolos macrofágicos}

A monitoração do pH intracelular e intravacuolar foi avaliada utilizando-se duas sondas fluorescentes: SNAFL-calceína AM (Molecular Probes) e laranja de acridina (Sigma-Aldrich). Os experimentos utilizando a sonda SNAFL-calceína AM foram conduzidos no laboratório do Prof. Dr. Renato Mortara, com auxílio do Dr. Walter Andreoli. Cerca de 4 × $10^{5}$ macrófagos extraídos de peritônio de camundongos BALB/c foram cultivados em placas plásticas com fundo de vidro Delta-T (Bioptechs, Butler, Estados Unidos). As células foram infectadas com promastigotas de fase estacionária de L. (L.) amazonensis na proporção de 7 parasitas por macrófago. O período de incubação foi de $3 \mathrm{~h}$ em estufa a $33{ }^{\circ} \mathrm{C}$ com atmosfera de $5 \% \mathrm{CO}_{2}$. Após a infecção, a cultura foi lavada 3 vezes com RPMI sem soro aquecido e incubada em RPMI completo para observação de diferentes campos óticos da cultura pelo sistema confocal BioRad 1024 UV anexado ao microscópio Zeiss Axiovert 100. Imagens foram obtidas por imersão em lente plano-apocromática $(63 \times 1.4)$ e o programa Lasersharp v. 3.2 TC foi utilizado para aquisição e processamento das imagens. As culturas foram tratadas com $10 \mu \mathrm{M}$ de tamoxifeno ou com o veículo etanol (0,25\%) imediatamente antes da observação para detecção de possíveis alterações no padrão de fluorescência da sonda SNAFL-calceína AM.

Para realização dos testes de coloração vacuolar de macrófagos derivados de medula óssea com laranja de acridina foi utilizado $10 \mu \mathrm{M}$ de laranja de acridina (estoque a $10 \mathrm{mM}$ em PBS 1X). As células controle ou infectadas (4 parasitas por macrófago) foram submetidas a tratamento com tamoxifeno $(10 \mu \mathrm{M})$ ou com o agente alcalinizante $\mathrm{NH}_{4} \mathrm{Cl}$ (5 ou $\left.10 \mu \mathrm{M}\right)$ por 
diferentes tempos (30 min, 4 e 24 h) para posterior incubação com laranja de acridina por 10 min a temperatura ambiente. As células foram imediatamente observadas por microscopia de fluorescência (Nikon-Microphot SX Fluorescence Microscope) em contraste de fase e através de filtros para fluoresceína e rodamina. O software ACT-1 Control foi utilizado para aquisição das imagens.

\subsection{Efeito do pH na atividade de tamoxifeno}

Promastigotas $\left(5 \times 10^{6}\right)$ ou amastigotas purificados de lesão $\left(1 \times 10^{7}\right)$ foram incubados em meio RPMI com $5 \%$ de SFB em diferentes faixas de $\mathrm{pH}$ : ácido $(4,5)$ ou neutro moderadamente alcalino $(7,5)$ por 4 or 24 h na ausência ou na presença de concentrações crescentes de tamoxifeno. As contagens de alíquotas das culturas foram realizadas em câmara de Neubauer.

\subsection{Marcação metabólica e extração de isoprenoides de $L$. (L.) amazonensis}

Aproximadamente $5 \times 10^{8}$ promastigotas de L. (L.) amazonensis em meio de cultura 199 foram incubados com etanol, tamoxifeno 10, 15 ou 17,5 $\mu \mathrm{M}$ por $2 \mathrm{~h}$ e em seguida foi adicionado $50 \mu \mathrm{Ci} / \mathrm{mL}$ de L-[U- $\left.{ }^{14} \mathrm{C}\right]$-leucina (radioatividade específica de $306 \mathrm{mCi} / \mathrm{mmol}$, Amersham Biosciences, GE Healthcare Life Sciences) às culturas para marcação radioativa por mais $22 \mathrm{~h}$. As culturas foram lavadas 3 vezes com PBS estéril, seguido de centrifugações a $1.000 \times \mathrm{g}$ por $10 \mathrm{~min}$. Os sedimentos obtidos ao final das lavagens foram congelados a $-20^{\circ} \mathrm{C}$ por $24 \mathrm{~h}$ e conservados a $-70^{\circ} \mathrm{C}$. As amostras foram liofilizadas. Os lipídios neutros dos parasitas marcados foram extraídos 3 vezes com $1 \mathrm{~mL}$ de hexano em sonicador por $15 \mathrm{~min}$ e as amostras foram centrifugadas a $1.000 \times \mathrm{g}$ por $5 \mathrm{~min}$ em cada uma das três extrações. Os extratos obtidos foram combinados e os sobrenadantes secos sob corrente de nitrogênio. As 
frações lipídicas foram congeladas a $-20{ }^{\circ} \mathrm{C}$. Alíquotas de cada extrato foram monitoradas quanto à detecção de radioatividade (cpm) em cintilador Beckman LS 5000 TD.

\subsection{Cromatografia em camada delgada de alta performance (HPTLC) de isoprenoides}

As amostras contendo frações de lipídios neutros foram ressuspensas em $80 \mu \mathrm{L}$ de hexano para posterior aplicação de $20 \mu \mathrm{L}$ da amostra em placa de sílica gel 60 (Merck). Para análise de lipídios neutros, o sistema utilizado foi hexano:éter dietílico:ácido acético (80:20:1; v:v:v), a temperatura ambiente. Padrões de CoQ10, farnesol, geraniol, dolicol (de 55 e 60 C) e ergosterol foram aplicados na mesma placa para verificar os $\mathrm{R} f \mathrm{~s}$ correspondentes. Os padrões foram visualizados com vapor de iodo. As placas ficaram expostas em cassetes de phosphor screen por 2 semanas para posterior leitura em scanner STORM 840 (Amersham Biosciences, GE Healthcare Life Sciences). Os produtos foram quantificados pelo software ImageQuant e a inibição calculada comparando-se a detecção da radioatividade de cada uma das bandas.

\subsection{Cromatografia líquida de alta performance (HPLC) de isoprenoides}

Para análise de dolicol e ergosterol foi utilizado um sistema de HPLC de fase reversa empregando-se uma coluna Beckman C18 (4,6 mm x 25 mm; tamanho da partícula de $5 \mu \mathrm{m}$ ). A análise foi realizada em cromatógrafo líquido de alta performance (Gilson ${ }^{\circledR}$ ). Os eluentes foram monitorados a $210 \mathrm{~nm}$. Foram utilizados dois solventes: o solvente A foi metanol:água $(9: 1, v / v)$ e o solvente B foi hexano:propan-2-ol:metanol $(1: 1: 2, \mathrm{v} / \mathrm{v} / \mathrm{v})$. Os solventes foram aplicados em gradiente linear iniciado com $95 \%$ de solvente $A / 5 \%$ de solvente $B$ até $100 \%$ de solvente $B$ em $25 \mathrm{~min}$, seguidos por $5 \mathrm{~min}$ de solvente $B$. O fluxo médio foi de 1,5 mL/min (Löw et al., 1991). A amostra radioativa foi co-injetada com uma mistura de padrões de farnesol, geraniol, ergosterol e dolicol de 55 e 60 carbonos. Frações de 0,5 minuto foram coletadas, secas à vácuo e ressuspensas em $1 \mathrm{~mL}$ de líquido de cintilação para contagem (cpm) em cintilador Beckman LS 5000 TD. 


\subsection{Marcação com iodeto de propídio e citometria de fluxo}

A integridade da membrana plasmática de promastigotas de L. (L.) amazonensis foi avaliada conforme descrito por Lima et al. (2007). Basicamente, culturas contendo $5 \times 10^{6}$ promastigotas de fase logarítmica foram incubados em PBS-glicose $1 \mathrm{~g} / \mathrm{L}$ na ausência ou na presença de 10 e $20 \mu \mathrm{M}$ de tamoxifeno diluído em etanol, Promastigotas foram também incubados com saponina (Sigma-Aldrich) 0,025\% preparada em solução fisiológica por diferentes tempos (0, 30 e $90 \mathrm{~min})$. Após a incubação com tamoxifeno ou saponina, às suspensões celulares foi adicionado $0,5 \mu \mathrm{g} / \mathrm{mL}$ de iodeto de propídio (IP; Sigma-Aldrich) e as

células foram analisadas por citometria de fluxo (BD FACSCanto ${ }^{\mathrm{TM}}$, Becton Dickinson, Estados Unidos) utilizando-se o software de análise Quest ${ }^{\circledR}$. A detecção de fluorescência foi adquirida utilizando-se o canal FL2 (laranja-vermelho: 585/42 nm BF). 10.000 eventos foram analisados por amostra e cada um dos dois ensaios foi realizado em triplicatas (Lima et al., 2007).

\subsection{Separação de fração de membrana e citosólica de promastigotas}

A separação de frações enriquecidas em membranas celulares foi realizada a partir de protocolo modificado de Kahl e McMahon-Pratt (Kahl e Mcmahon-Pratt, 1987). Culturas de promastigotas de fase logarítmica de $L$. (L.) amazonensis $\left(5 \times 10^{8}\right)$ foram incubadas em PBSglicose $1 \mathrm{~g} / \mathrm{L}$ na ausência ou na presença de $20 \mu \mathrm{M}$ de tamoxifeno por $30 \mathrm{~min}$. Após o período de incubação, as culturas foram lavadas 3 vezes em PBS 1X e ressuspensas em água estéril (vol. final $1 \mathrm{~mL}$ ). As suspensões foram congeladas em nitrogênio líquido por 1 min e a seguir descongeladas em banho a $37^{\circ} \mathrm{C}$ por $1 \mathrm{~min}$. O procedimento foi repetido 4 vezes. Alíquotas de $10 \mu \mathrm{L}$ foram examinadas em microscópio para nos certificarmos de que as células estavam rompidas. A solução foi centrifugada por $10 \mathrm{~min}$ a $4.300 \times \mathrm{g}$ e o sobrenadante foi coletado para nova centrifugação a 14.270 x g por 30 min. A fração solúvel foi denominada fração citosólica (FC) e o sedimento foi denominado fração de membranas (FM). Extratos lipídicos de frações enriquecidas de membranas (FM) ou citosólica (FC) foram obtidos como descrito no item 3.23.3. Os extratos foram ressuspensos em clorofórmio:metanol (2:1, v:v) e alíquotas de 
$25 \mu \mathrm{L}$ de cada amostra foram aplicadas em placas de sílica gel (250F com indicador para fluorescência, JT Baker) e submetidas à cromatografia em camada delgada (TLC) com sistema de solventes clorofórmio:metanol:água (60:35:8, v:v:v) para corrida de $2 \mathrm{~cm}$ e o restante da placa em clorofórmio:metanol:ácido acético (90:2:8, v:v:v). A placa foi seca e visualizada por exposição à luz UV-onda curta para detecção da banda referente ao tamoxifeno $\left(\lambda_{\text {máx }}\right.$ de 274 $\mathrm{nm}$ ) (Bathia et al., 2004). Amostra contendo apenas o padrão puro de tamoxifeno foi utilizada para se obter o $\mathrm{R} f$ da molécula.

\subsection{Microscopia ótica}

Culturas de promastigotas de L. (L.) amazonensis ressuspensas em PBS-glicose 1g/L foram mantidas na ausência ou na presença de tamoxifeno, MAPP ou PDMP por diferentes períodos de incubação a depender do experimento. A seguir foram montados esfregaços em lâminas que, após secos, foram fixados em metanol puro para posterior coloração com o kit Instant Prov ${ }^{\circledR}$ (Brasil). As lâminas foram observadas em microscópio ótico Nikon Eclipse E200 em aumento de $1000 \mathrm{X}$ e imagens de diferentes campos óticos foram obtidas com câmera fotográfica digital Sony CyberShot 7.2M.

\subsection{Microscopia eletrônica de transmissão}

Os experimentos de microscopia eletrônica de transmissão foram realizados no laboratório da Profa. Dra. Tania Katzin (ICB/USP), com auxílio do Sr. Alexandre Santos de Moura. Alíquotas de $1 \times 10^{8}$ promastigotas de L. (L.) amazonensis que não receberam tratamento ou tratados com tamoxifeno, MAPP ou PDMP por $2 \mathrm{~h}$ foram fixados em solução contendo $1 \%$ de glutaraldeído, $1 \%$ de paraformaldeído em tampão cacodilato de sódio 0,1 M, $\mathrm{pH} 7,2$, com $\mathrm{CaCl}_{2}$ 0,5 mM e solução saturada de ácido pícrico $0,2 \%$ por 5 min a temperatura 
ambiente e posteriormente a $4{ }^{\circ} \mathrm{C}$ por $1 \mathrm{~h}$. Os parasitas foram a seguir pós-fixados com $\mathrm{OsO}_{4}$ 1\%. As amostras foram ressuspensas em solução salina:sacarose (0.9\%:1.7\%) e acetato aquoso de uranila $0.5 \%$ para posterior desidratação em etanol $70 \%$ e inclusão em resina LRWhite hard grade (The London Resin Co. LTD). As amostras foram observadas em microscópio eletrônico de transmissão JEOL $100 C X$ II.

\subsection{Investigação do metabolismo de esfingolipídios em $L$. (L.) amazonensis}

\subsubsection{Ensaios de viabilidade celular na presença de Fumonisina B1, MAPP, PDMP e PPMP}

Culturas de parasitas com inóculo de $3 \times 10^{6}$ células ou $2 \times 10^{6}$ células de mamíferos (CHO-K1 e HEp-2) foram tratadas com os seguintes inibidores de diversas enzimas da rota biossíntética de esfingolipídios em mamíferos (revisado em Merril Jr e Sandhoff, 2002): Fumonisina B1 (inibidor da ceramida sintase), MAPP (inibidor da ceramidase) e PDMP e PPMP (inibidores da glucosilceramida sintase). Todos os compostos foram adquiridos de SigmaAldrich e diluídos em etanol a 5 ou $10 \mathrm{mM}$ para armazenamento a $-20^{\circ} \mathrm{C}$. A viabilidade tanto das culturas celulares quanto dos parasitas foi avaliada conforme descrito nos itens $\mathbf{3 . 4}$ e $\mathbf{3 . 7}$ para os quais também foram obtidos os valores de $\mathrm{IC}_{50}$ e $\mathrm{CC}_{50}$.

\subsubsection{Incorporação de $C_{6}$-NBD-ceramida por promastigotas de L. (L.) amazonensis}

$\mathrm{C}_{6}$-NBD-cer ( $\mathrm{C}_{6}$-NBD-ceramida; (N-(7-(4-nitrobenzo-2-oxa-I,3-diazol))-6-aminocaproil-Deritroesfingosina); Molecular Probes, Invitrogen) foi adicionada a culturas de promastigotas de $L$. (L.) amazonensis a uma concentração final de $5 \mu \mathrm{M}$ em solução balanceada de Hanks com EDTA $10 \mathrm{mM}$ (Sigma-Aldrich) por $5 \mathrm{~min}$ a $4{ }^{\circ} \mathrm{C}$ ou $5 \mathrm{~min}$ a $4{ }^{\circ} \mathrm{C}$ seguidos de $15 \mathrm{~min}$ a 
temperatura ambiente. Esfregaços foram realizados em lâminas de vidro para análise dos parasitas vivos por microscopia de fluorescência (Nikon-Microphot SX Fluorescence Microscope). DAPI a $10 \mu \mathrm{g} / \mathrm{mL}$ (Sigma-Aldrich) foi adicionado no momento da análise para detecção de núcleo e kDNA. As aquisição das imagens foi obtida com o software ACT-1 e a sobreposição das mesmas foi realizada através do software Image ${ }^{\circledR}$.

\subsubsection{Marcação metabólica, extração lipídica de L. (L.) amazonensis e HPTLC}

Culturas contendo 1 a $4 \times 10^{8}$ promastigotas ou $1 \times 10^{7}$ amastigotas foram incubadas com $10 \mu \mathrm{M}$ de tamoxifeno, $100 \mu \mathrm{M}$ de PDMP ou $200 \mu \mathrm{M}$ de MAPP por $1 \mathrm{~h}$ e $30 \mathrm{~min}$. Em seguida foi adicionado $10 \mu \mathrm{M}$ de $\mathrm{C}_{6}$-NBD-cer, $5 \mu \mathrm{M}$ de NBD-esfinganina ou NBD-esfingosina em etanol (Avanti Polar Lipids) às culturas para marcação fluorescente por mais $2 \mathrm{~h}$ e 30 min. Ao final do período de incubação, foram obtidos extratos lipídicos após 3 extrações sucessivas com clorofórmio:metanol:solução de Hanks/EDTA 10 mM (1:1:0,75; v:v:v). Os sistemas de solventes utilizados em diversos dos nossos experimentos foram:

A) butanol:ácido acético:água (3:1:1; v:v:v) (Boath et al., 2008) e

B) clorofórmio:metanol:água (60:35:8; v:v:v) para 20\% de corrida da placa e, para o restante, clorofórmio:metanol:ácido acético (90:2:8; v:v:v) (Ichikawa et al., 1994).

Após as corridas, as placas foram analisadas em leitor de fluorescência (STORM 840) para deteç̧ão de bandas com sinal para o fluoróforo NBD (excitação/emissão: 455/530 nm). As cromatografias foram realizadas evitando-se o contato com luz direta. Os produtos foram quantificados quanto à incorporação de fluorescência utilizando-se o software ImageJ $^{\circledR}$ e o aumento ou inibição calculados comparando-se a intensidade de cada uma das bandas em relação ao grupo controle. Os padrões conjugados a NBD (NBD-livre, NBD-lactosilceramida e NBD-galactosilceramida) foram gentilmente cedidos pela Profa. Dra. Alicia Couto (Universidade de Buenos Aires, Argentina). Os padrões de esfingolipídios não fluorescentes como esfingomielina, monohexosil-ceramida e ceramida 1-fosfato foram gentilmente cedidos 
pela Profa. Dra. Anita Straus (Universidade Federal de São Paulo) e visualizados após exposição da placa ao vapor de iodo.

\subsubsection{Deteç̧ão de ceramida por imunofluorescência e citometria de fluxo}

Os experimentos descritos a seguir foram conduzidos no Laboratório da Profa. Dra. Norma Andrews da Universidade de Maryland, Estados Unidos. Aproximadamente $5 \times 10^{8}$ promastigotas de L. (L.) amazonensis foram cultivados em meio 199 por $1 \mathrm{~h}$ na ausência ou presença de $200 \mu \mathrm{M}$ de MAPP ou $100 \mu \mathrm{M}$ de PDMP. A seguir as células foram lavadas em PBS em centrifugação a 1.000 x g por 10 min para fixação dos sedimentos com paraformaldeído 4\%/PBS por 20 min. Em seguida, as células foram homogeneizadas em PBS por 5 min em agitação leve para posterior bloqueio com BSA $2 \% / P B S$ a $4{ }^{\circ} \mathrm{C}$. Após duas lavagens com PBS, ressuspendeu-se o sedimento em Triton 0,05\% com BSA 0,4\%/PBS por 15 min para permeabilização das células. A seguir os parasitas foram lavados em PBS uma vez e ressuspensos em $100 \mu \mathrm{L}$ de BSA 0,2\%/PBS contendo o anticorpo anti-ceramida (1:10, SigmaAldrich) por $1 \mathrm{~h}$. As células foram lavadas após esse período e incubadas com o anticorpo secundário anti-mouse-IgM-Alexa Flour 594 (Invitrogen) a uma diluição de 1:500 em BSA 0,2\%/PBS por $1 \mathrm{~h}$. Após este período as células foram novamente lavadas e alíquotas de $10 \mu \mathrm{L}$ foram montadas em lâminas de vidro, seladas com esmalte para posterior análise em microscópio de fluorescência (Axiovert 200; Carl Zeiss, Inc.) equipado com objetiva de 60x NA 1.25, câmera (CoolSNAP HQ; Photometrics) e o software MetaMorph (MDS Analytical Technologies). Para os ensaios de citometria de fluxo (FACSCalibur BD, Becton Dickinson, Estados Unidos), foram realizados os mesmos procedimentos exceto pela adição do anticorpo secundário (anti-mouse-IgM-Alexa Fluor 647, 1:500. Invitrogen) por 1 h. Após lavagem das células, alíquotas de $250 \mu \mathrm{L}$ foram mantidas em gelo para serem analisadas por FACS com deteç̧ão de pelo menos 10.000 eventos por amostra. Os dados foram analisados através do software FlowJo version 6.3 (Tree Star, Inc.). 


\subsubsection{Espectrometria de massas}

As bandas obtidas após a cromatografia em camada delgada foram raspadas da sílica e re-extraídas com clorofórmio:metanol $(2: 1 ; \mathrm{v}: \mathrm{v})$. As amostras foram identificadas quanto à relação massa/carga $(\mathrm{m} / \mathrm{z})$ por espectrometria de massas por tempo de voo com ionização e dessorção a laser assistida por matriz ultravioleta (UVMALDI-TOF MS) em espectrofotômetro de massas Ultraflex II TOF/TOF equipado com laser de estado sólido de alta performance $(\lambda=355 \mathrm{~nm})$ e um refletor. O sistema foi operado através do software Flexcontrol 2.4 (Bruker Daltonics $\mathrm{GmbsH}$, Bremen, Alemanha). Todas as análises foram realizadas no laboratório CIHIDECAR (Universidade de Buenos Aires, Argentina) pela Profa. Dra. Alicia Couto, Dra. Malena Landoni e Tamara Piñero. O protocolo executado foi baseado na metodologia descrita por este grupo, para a qual não há necessidade do uso de matriz externa no processo de análise do material, já que o próprio fluoróforo NBD empregado nas marcações metabólicas pode ser excitável, levando à obtenção de espectros de alta qualidade (Landoni et al., 2008).

\subsection{Obtenção da linhagem $L$. (L.) amazonensis expressora do gene LUC}

\subsubsection{Eletroporação e obtenção de clones}

Clones de Leishmania recombinantes foram obtidos utilizando-se o protocolo de transfecção de tripanossomatídeos desenvolvido por Coburn e Beverley (1990). Resumidamente, promastigotas de fase exponencial de L. (L.) amazonensis foram lavados por centrifugação a 700 x g por $10 \mathrm{~min}$. Descartou-se o sobrenadante e o sedimento obtido foi ressuspenso em $10 \mathrm{~mL}$ de tampão de eletroporação (EPB) (HEPES $21 \mathrm{mM} \mathrm{pH} \mathrm{7,5,} \mathrm{NaCl} 137$ $\mathrm{mM}, \mathrm{KCl} 5 \mathrm{mM}, \mathrm{Na}_{2} \mathrm{HPO}_{4}$ 0,7 mM e glicose $6 \mathrm{mM}$ ) para posterior centrifugação sob as mesmas condições, desprezando-se o sobrenadante. As células foram ressuspensas em EPB a uma 
densidade de $10^{8} / \mathrm{mL}$ e mantidas em gelo. Em tubos tipo eppendorf ${ }^{\oplus}$, foram misturados 400 $\mu \mathrm{L}$ da suspensão celular (equivalente a $4 \times 10^{7}$ células) e $50 \mu \mathrm{g}$ das construções de DNA (plasmídio pXG1 e plasmídio pXG1Luc construído pela aluna de Mestrado Sandra Kalil (Kalil, 2010)), exceto para o grupo controle que não recebeu DNA. A mistura foi transferida a cubetas de 0,2 cm mantidas em gelo e a eletroporação realizada em voltagem de 0,4 kV $(2,25$ $\mathrm{kV} / \mathrm{cm}$ ) e $960 \mu \mathrm{F}$ de capacitância. Em seguida, as cubetas foram mantidas em gelo e o volume total da cultura transfectada foi transferido a $10 \mathrm{~mL}$ de meio 199 para incubação por $24 \mathrm{~h}$ a 25 ${ }^{\circ} \mathrm{C}$ sem antibiótico. Transcorridas $24 \mathrm{~h}$, o volume total das culturas transfectadas foi centrifugado a 700 x g por 10 min e o sobrenadante foi descartado cuidadosamente para posterior homogeneização do sedimento no meio residual. As células transfectadas foram mantidas em passagens sucessivas em meio líquido na presença de geneticina $(60 \mu \mathrm{g} / \mathrm{mL}$ ) por aproximadamente 1 mês e posteriormente foram plaqueadas com alça de Drigalski em meio semi-sólido (Meio 199 2X, biopterina 1,2 $\mu \mathrm{g} / \mathrm{ml}$, ágar 2\%, urina 2\%, contendo $120 \mu \mathrm{g} / \mathrm{mL}$ de Geneticina) de modo que a superfície permanecesse úmida. As placas foram vedadas para evitar desidratação e contaminação. A seleção de colônias foi realizada entre o quarto e décimo dia para culturas controle sem antibiótico e após mais 12 dias para células transfectadas em meio contendo o antibiótico geneticina $(120 \mu \mathrm{g} / \mathrm{mL})$ (Coburn e Beverley, 1990).

As colônias de Leishmania foram coletadas com ponteira estéril e ressupensas em meio 199 com o antibiótico de seleção em placas de 96 poços. As culturas foram posteriormente expandidas em placas de 24 poços. Por último, foram transferidas a garrafas de $25 \mathrm{~cm}^{2}$.

\subsubsection{Atividade de luciferase}

A atividade de luciferase foi avaliada a partir do protocolo descrito pelo fabricante do kit "Luciferase Assay System" (Promega $\left.{ }^{\circledR}\right)$. Cada poço de placas de 96 poços contendo macrófagos infectados (5 promastigotas expressando o gene da luciferase por macrófago) foi 
lavado com PBS 1X. Culturas de promastigotas transfectadas foram recuperadas e as suspensões centrifugadas a $700 \mathrm{x} g$ durante $10 \mathrm{~min}$ para posterior lavagem também com PBS 1X. O sedimento obtido após duas lavagens foi ressuspenso em tampão de lise (Luciferase Assay System, Promega ${ }^{\circledR}$ ) e, no caso das infecções, o tampão foi adicionado diretamente no poço da placa contendo as células aderidas com vigorosa ressuspensão. Os lisados foram transferidos a tubos eppendorf ${ }^{\circledR}$ e homogeneizados em agitador tipo vortex por $15 \mathrm{~s}$ e centrifugados a $12.000 \times \mathrm{g}$ durante $15 \mathrm{~s}$ a temperatura ambiente. Em diferentes tubos BD arredondados de $5 \mathrm{~mL}$ (Falcon ${ }^{\circledR}$ ) contendo $20 \mu \mathrm{L}$ de substrato de luciferase (Luciferase Assay System, Promega ${ }^{\circledR}$ ) mantidos em gelo, foram adicionadas alíquotas de $80 \mu \mathrm{L}$ do sobrenadante de cada lisado. As amostras foram analisadas imediatamente em luminômetro (Luminometer Lumat LB 9507) e os valores obtidos expressando as unidades relativas de luz (RLU). 
4 RESULTADOS E DISCUSSÃO 


\subsection{Atividade leishmanicida de tamoxifeno}

\subsubsection{Atividade in vitro de tamoxifeno contra Leishmania}

Resultados preliminares obtidos em nosso laboratório indicavam que promastigotas de L. (L.) amazonensis cultivados na presença de 20 a $30 \mu \mathrm{M}$ de tamoxifeno tinham sua multiplicação completamente inibida. Com o intuito de estabelecermos as faixas de concentrações inibitórias de tamoxifeno para 50 e $90 \%$ das culturas $\left(I_{50}\right.$ e $I C_{90}$, respectivamente) e verificarmos se este fármaco induziria um efeito dose-resposta contra o parasita, experimentos in vitro foram conduzidos e mostraram que o tamoxifeno tem efeito leishmanicida, em 24 horas, sobre culturas de promastigotas de diversas espécies do gênero Leishmania. Comparativamente, os valores de $\mathrm{IC}_{50}$ são próximos para as diferentes espécies (9,0 a 20,2 $\mu \mathrm{M})$ o que sugere um provável mecanismo de ação semelhante contra os parasitas, fato interessante do ponto de vista terapêutico, já que foi avaliada a sensibilidade ao tamoxifeno de espécies causadoras de distintas manifestações clínicas da doença. Foram realizados, também, experimentos com amastigotas de L. (L.) amazonensis extraídos e purificados de lesão de camundongos BALB/c. Os dados obtidos demonstram que tamoxifeno reduz em 50\% o número total de parasitas em uma concentração de 11,0 $\mu \mathrm{M}$. A atividade deste fármaco foi determinada também para macrófagos peritoniais ou derivados de medula óssea de camundongos BALB/c infectados com L. (L.) amazonensis, L. (V.) braziliensis e L. (L.) chagasi. Tamoxifeno levou à redução das taxas de infecção apresentando valores de $\mathrm{IC}_{50}$ entre 1,7 e 5,6 $\mu \mathrm{M}$, ligeiramente inferiores quando comparados àqueles obtidos para parasitas axênicos. Os resultados detalhados encontram-se descritos nos artigos: - "Tamoxifen is effective against Leishmania and induces a rapid alkalinization of parasitophorous vacuoles harbouring Leishmania (Leishmania) amazonensis amastigotes" (ANEXO A)

- "Tamoxifen as a potential antileishmanial agent: efficacy in the treatment of Leishmania braziliensis and Leishmania chagasi infections" (ANEXO B).

\subsubsection{Atividade de tamoxifeno no tratamento de leishmaniose em modelos de roedores}


4.1.2.1 Infecção por L. (L.) amazonensis

Após a determinação da atividade de tamoxifeno in vitro, foram realizadas infecções experimentais em roedores para se estabelecer a eficácia deste fármaco a partir de diferentes vias de administração.

Primeiramente, camundongos BALB/c foram infectados com L. (L.) amazonensis e, após o aparecimento das lesões na base da cauda, o tratamento com injeção intraperitoneal de $20 \mathrm{mg} / \mathrm{kg} / \mathrm{dia}$ de citrato de tamoxifeno foi realizado por 15 dias. Nossos resultados mostraram que este fármaco diminuiu significativamente o tamanho das lesões e o desenvolvimento das úlceras, conforme descrito no artigo "Tamoxifen is effective in the treatment of Leishmania amazonensis infections in mice" (ANEXO C). Além disso, o tratamento com tamoxifeno levou à redução da carga parasitária tanto no sítio da lesão como nos linfonodos dorso-caudais. É importante ressaltar que o efeito observado neste ensaio foi bastante promissor, dada a alta suscetibilidade deste modelo murino à infecção por esta espécie (Soong et al., 1997).

Além da via intraperitoneal, tamoxifeno também foi administrado por via oral e/ou tópica. Para isso, camundongos BALB/c infectados na base da cauda com promastigotas de $L$. (L.) amazonensis tiveram suas lesões medidas semanalmente e, um mês após a infecção, os animais foram tratados por 21 dias de acordo com o seguinte esquema:

A. $25 \mathrm{mg} / \mathrm{kg} /$ dia de tamoxifeno em solução etanólica por via tópica, B. $20 \mathrm{mg} / \mathrm{kg} / \mathrm{dia}$ de citrato de tamoxifeno via oral e C. $20 \mathrm{mg} / \mathrm{kg} / \mathrm{dia}$ de citrato de tamoxifeno via oral e 12,5 $\mathrm{mg} / \mathrm{kg} /$ dia de tamoxifeno em solução etanólica via tópica.

A Figura 3 mostra o perfil de evolução das lesões de camundongos do grupo controle infectado e não tratado (curva representativa da média de 8 camundongos) em comparação às medidas obtidas para cada animal do grupo tratado apenas com aplicação tópica de tamoxifeno (Figura 3A), de camundongos tratados apenas por via oral (Figura 3B) e do grupo que recebeu citrato de tamoxifeno via oral além de metade dessa dose via tópica (Figura $3 C$ ). 

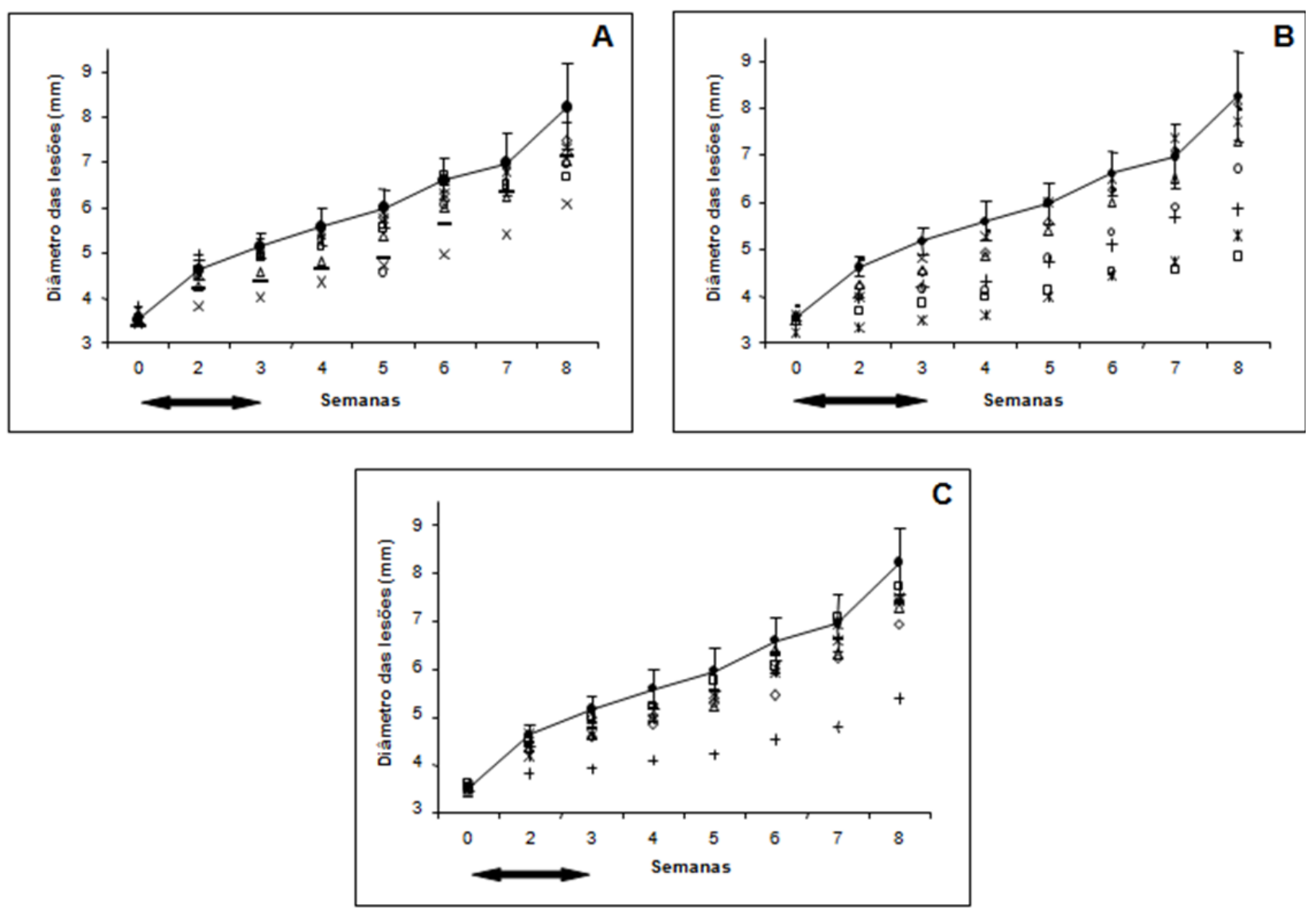

Figura 3. Evolução do diâmetro médio das lesões de camundongos BALB/c infectados na base da cauda com promastigotas de $L$. (L.) amazonensis e tratados com tamoxifeno. As curvas indicam o aumento da lesão para a média das medidas de 8 camundongos do grupo infectado e não tratado. Cada animal tratado está representado por um símbolo distinto. (A): Camundongos tratados com $25 \mathrm{mg} / \mathrm{kg} / \mathrm{dia}$ de tamoxifeno por via tópica. (B): Camundongos tratados com $20 \mathrm{mg} / \mathrm{kg} / \mathrm{dia}$ de citrato de tamoxifeno por via oral. (C): Camundongos tratados com $20 \mathrm{mg} / \mathrm{kg} / \mathrm{dia}$ de citrato de tamoxifeno por via oral além de $12,5 \mathrm{mg} / \mathrm{kg} / \mathrm{dia}$ de tamoxifeno por via tópica. A seta indica o período de tratamento e as barras representam o desvio-padrão. 0 tratamento foi iniciado após estabelecimento de lesão ( 30 a 45 dias pós-infecção).

De maneira geral podemos notar uma tendência de redução dos diâmetros das lesões dependendo da via de administração da droga. Esses resultados sugerem que tamoxifeno, administrado oralmente, foi mais eficaz que os tratamentos por via tópica e, curiosamente, por via tópica associada à via oral. Contudo, quando comparamos estes resultados com aqueles obtidos para o tratamento descrito anteriormente (ANEXO C), podemos observar que tamoxifeno é mais eficaz quando administrado pela via intraperitoneal. Além deste fator, a 
eficácia parece ainda mais pronunciada se notarmos que o tempo de tratamento neste último caso foi inferior (15 dias) ao empregado para os tratamentos por via tópica, via oral ou associadas (21 dias).

Mesmo não apresentando resultados tão promissores, uma nova estratégia foi adotada na tentativa de potencializarmos a atividade in vivo de tamoxifeno quando aplicado por via tópica (considerada ideal para o tratamento das lesões cutâneas). Com base em resultados obtidos anteriormente em que demonstramos a atividade leishmanicida do terpeno limoneno contra Leishmania (Arruda et al., 2009) e nos estudos de El-Kattan e colaboradores, que demonstraram o efeito deste terpeno no aumento da permeabilidade cutânea tanto para drogas lipofílicas quanto para hidrofílicas (El-Kattan et al., 2001), combinamos limoneno ao tamoxifeno em solução etanólica para uso em nossos ensaios. No grupo de camundongos que recebeu aplicações tópicas de tamoxifeno 10 $\mathrm{mg} / \mathrm{kg} /$ dia+limoneno $2 \%$ por 21 dias, foram observadas diferenças significativas entre os camundongos do grupo tratado e não tratado (Figura 4). Contudo, não foi possível notar diferença no perfil da progressão das lesões entre o grupo tratado apenas com tamoxifeno e aquele tratado com tamoxifeno+limoneno $2 \%$ (dados não apresentados), fato que talvez possa ser explicado pela baixa concentração utilizada deste terpeno. 


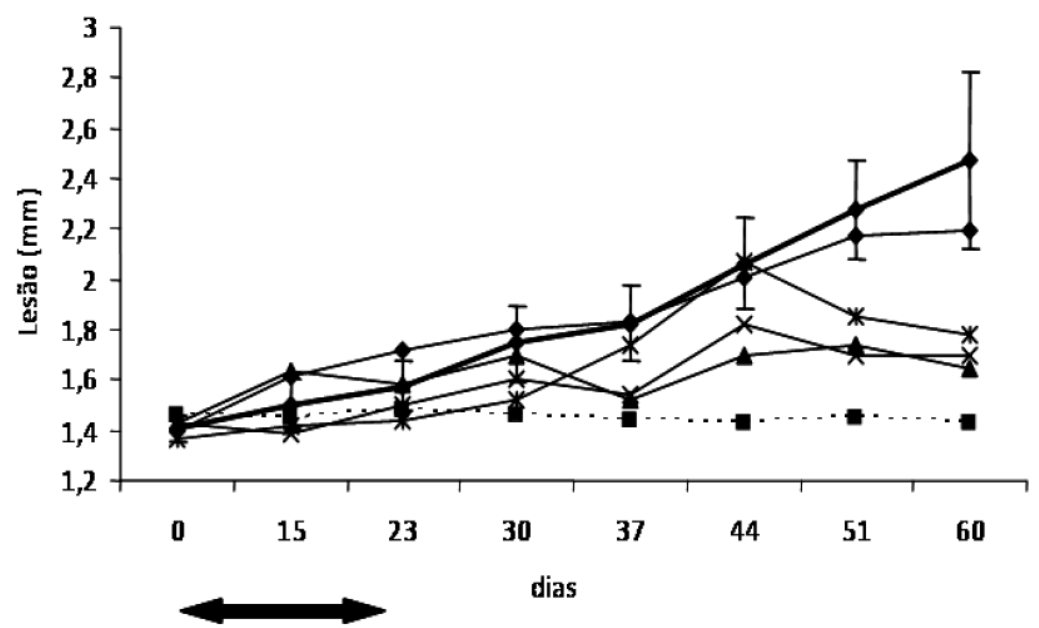

Figura 4. Evolução do diâmetro das lesões de camundongos BALB/c infectados na base da cauda com $L$. (L.) amazonensis e tratados com $10 \mathrm{mg} / \mathrm{kg} /$ dia de tamoxifeno + limoneno $2 \%$. Cada curva independente representa o desenvolvimento da lesão para cada um dos camundongos tratados e a curva com as barras verticais dos desvios-padrão refere-se à média das medidas de 5 camundongos do grupo infectado e não tratado. A seta indica o período de tratamento (21 dias). 0 tratamento foi iniciado após estabelecimento de lesão (30 a 45 dias pós-infecção).

Neste experimento foram incluídos dois outros controles: um grupo infectado e tratado com etanol e um grupo infectado e tratado com etanol+limoneno $2 \%$. Verificou-se que não houve interferência na evolução da doença para os animais em ambos os casos (resultados não apresentados). Um animal do grupo controle tratado com etanol morreu de causa indeterminada após 54 dias do início do tratamento.

Outra tentativa empregada para melhorarmos a eficácia da atividade leishmanicida in vivo de tamoxifeno foi realizar o seu encapsulamento em vesículas lipossomais, uma vez que esta técnica já foi estabelecida em estudos para aplicação tópica do fármaco associado a matrizes de gel e suspensões lipossomais (Bathia et al., 2004; Rouanet et al., 2005). Tal abordagem parece interessante do ponto de vista clínico, uma vez que se espera que os efeitos colaterais sistêmicos de tamoxifeno sejam reduzidos quando sua aplicação passa a ser concentrada apenas na área lesionada.

Assim sendo, obtivemos formulações lipossomais a partir da secagem de emulsões lipídicas contendo tamoxifeno, fosfatidilcolina e ergosterol ou tamoxifeno, fosfatidilcolina e colesterol (10:100:50). Formulações sem tamoxifeno também foram obtidas e utilizadas como controles de formulações na ausência da droga. Ergosterol foi utilizado como alternativa em uma das formulações com o intuito de produzirmos vesículas que apresentassem um 
componente já presente na membrana plasmática de Leishmania e que poderia facilitar a incorporação destes lipossomas na mesma. Conseqüentemente, haveria maior facilidade de a droga atingir o alvo desejado.

As formulações obtidas foram observadas por microscopia ótica para confirmação da estrutura vesicular (Figura 5).

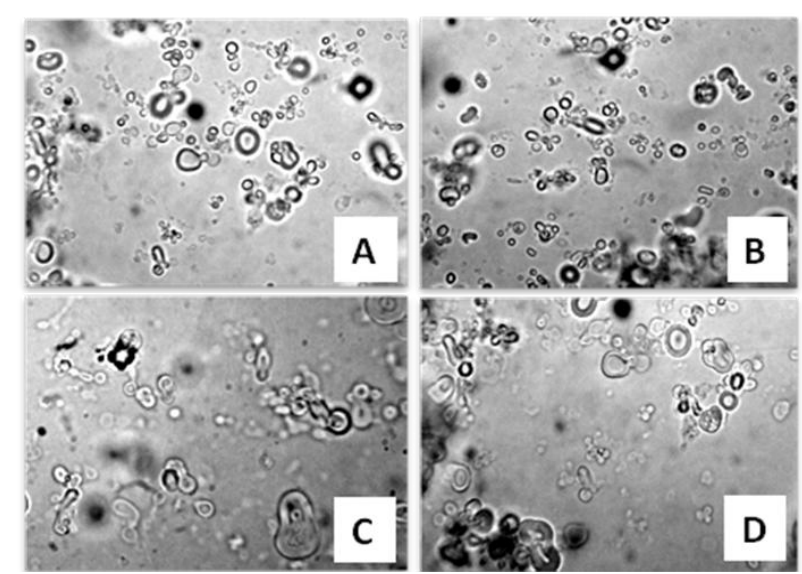

Figura 5. Preparações lipossomais fotografadas em microscopia ótica. Lipossomos obtidos a partir de formulações contendo fosfatidilcolina (PC), ergosterol (ERG), colesterol (COL) e tamoxifeno (TAM). (A): PC, ERG, TAM. (B): PC, ERG. (C): PC, COL, TAM. (D): PC, COL. Aumento de 1000X.

Alíquotas de cada uma das preparações foram separadas para posterior quantificação aproximada de droga incorporada nos lipossomos. Na Tabela 1 podemos verificar que a incorporação na formulação contendo ergosterol foi aproximadamente 7,5\% mais eficiente que a formulação contendo colesterol. Estudos anteriores já haviam demonstrado que tamoxifeno mimetiza colesterol e, de forma mais pronunciada, ergosterol quando incorporado em bicamadas lipídicas in vitro (Wiseman et al., 1992).

Tabela 1 - Efeito da composição lipídica na incorporação de tamoxifeno em lipossomos.

\begin{tabular}{ccc}
\hline Formulação* & $\begin{array}{c}\text { Quantidade de droga } \\
\text { incorporada }(\mathrm{mg} / \mathrm{mL})\end{array}$ & PDE** \\
\hline PC, ERG, TAM & 12.3 & $41 \%$ \\
PC, ERG & - & - \\
PC, COL, TAM & 10.1 & $33.6 \%$ \\
PC, COL & - & - \\
\hline
\end{tabular}

* PC; fosfatidilcolina, ERG; ergosterol, TAM; tamoxifeno e COL; colesterol. ** PDE; porcentagem de droga encapsulada $=$ Droga encapsulada $(\mathrm{mg}) /$ Total de droga adicionada $(\mathrm{mg}) \times 100$. 
Após a preparação, as formulações foram empregadas no tratamento de camundongos BALB/C infectados na base da cauda com promastigotas de $L$. (L.) amazonensis por 15 dias consecutivos, na dose equivalente a $10 \mathrm{mg} / \mathrm{kg} / \mathrm{dia}$ de tamoxifeno via intraperitoneal. Na Figura 6 podemos observar uma tendência importante de retardamento no desenvolvimento das lesões dos animais que receberam a formulação lipossomal contendo ergosterol e tamoxifeno em relação aos animais não tratados ou que receberam apenas a formulação sem a droga (Figura 6). Entretanto, verificamos que 3 dos 7 animais tratados apresentavam lesões com diâmetros comparáveis àqueles observados em animais não tratados. Além disso, 3 semanas após o final do tratamento, observamos que o tamanho das lesões de todos os animais eram praticamente equivalentes, tanto no grupo tratado quanto nos grupos controle que não receberam tamoxifeno. Quanto às formulações contendo colesterol, não observamos diferenças significativas quanto ao tratamento com lipossomas contendo ergosterol (dados não mostrados). Apesar de utilizarmos nesse caso uma dose correspondente à metade da empregada em experimentos com a droga não encapsulada, a premissa de que os lipossomos resultariam em incremento de atividade in vivo não se confirmou.

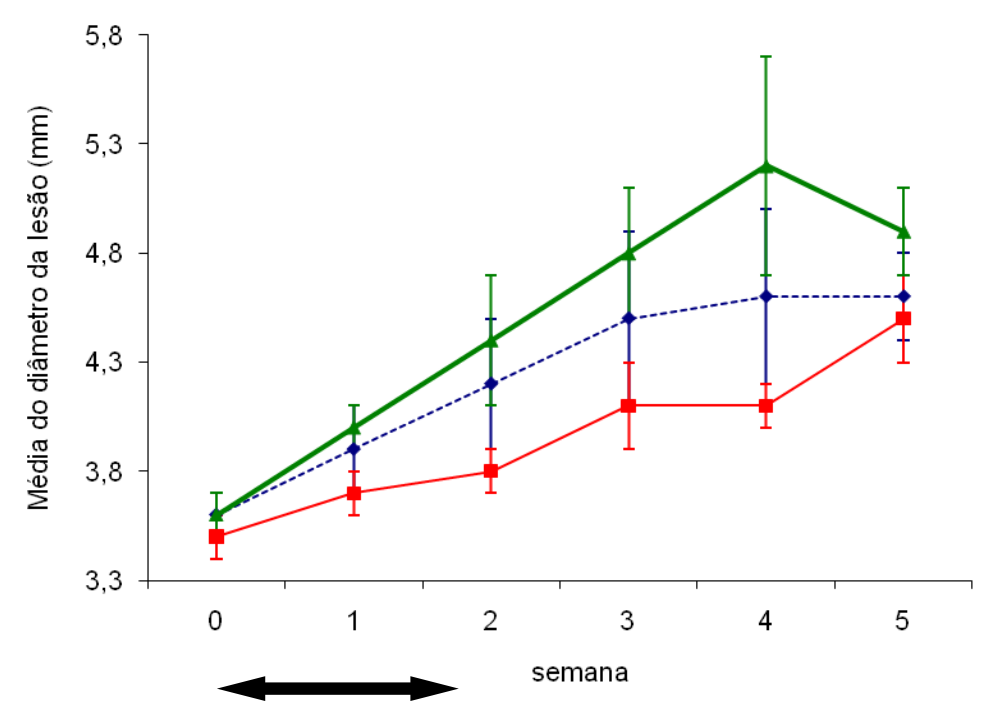

Figura 6. Evolução do diâmetro médio das lesões de camundongos BALB/c infectados com promastigotas de $L$. amazonensis e tratados com formulação lipossomal contendo tamoxifeno via intraperitoneal. As curvas indicam o aumento da lesão para a média das medidas de 7 camundongos do grupo não tratado (azul), tratado com formulação lipossomal contendo tamoxifeno (vermelho) e tratado com lipossomas sem droga (verde). A seta indica o período de tratamento e as barras representam o desvio-padrão. $O$ tratamento foi iniciado após estabelecimento de lesão (30 a 45 dias pós-infecção). 


\subsubsection{Infecção por L. (V.) braziliensis e L. (L.) chagasi}

A atividade do tamoxifeno em modelos de leishmaniose cutânea e visceral causadas por L. (V.) braziliensis e L. (L.) chagasi, respectivamente, também foi estabelecida e encontrase descrita no artigo intitulado "Tamoxifen as a potential antileishmanial agent: efficacy in the treatment of Leishmania braziliensis and Leishmania chagasi infections" (ANEXO B). Resumidamente, nossos resultados destacam que as lesões induzidas por $L$. (V.) braziliensis no pavilhão auricular de camundongos $\mathrm{BALB} / \mathrm{c}$ foram reduzidas após tratamento com 20 $\mathrm{mg} / \mathrm{kg} /$ dia de tamoxifeno via intraperitoneal por 2 semanas. Além disso, as cargas parasitárias também foram significativamente menores após administração de tamoxifeno em comparação ao grupo tratado com salina.

Para a avaliação da eficácia do tamoxifeno em infecções por $L$. (L.) chagasi foram utilizados hamsters dourados. A sintomatologia e a progressão da doença nestes animais assemelham-se muito às características da doença no humano. Nestes roedores, a infecção também compromete fígado e baço (órgãos que apresentam alta carga parasitária) e pode levar à perda gradual de peso em poucas semanas. A administração intraperitoneal de 20 $\mathrm{mg} / \mathrm{kg} /$ dia de citrato de tamoxifeno por duas semanas consecutivas resultou na diminuição significativa do número de parasitas no fígado e baço dos animais quando comparado aos grupos que receberam solução salina ou antimoniato de meglumina. Além disso, a taxa de sobrevivência foi analisada entre os diferentes grupos. O tratamento com tamoxifeno resultou no prolongamento da sobrevivência dos hamsters infectados quando comparados aos animais do grupo controle.

\subsubsection{Atividade do metabólito 4-hidróxi-tamoxifeno contra L. (L.) amazonensis}

O tamoxifeno é extensivamente metabolizado pelo sistema citocromo P450 (CYP) às suas formas $\mathrm{N}$-desmetilada, 4-hidroxilada, 4-hidróxi-N-desmetilada e N-desdimetilada. N- 
desmetil-tamoxifeno e 4-hidróxi-tamoxifeno (4-OH-TAM) são os produtos iniciais formados a partir da molécula de tamoxifeno, sendo que o primeiro deles é o principal metabólito circulante no soro humano (Adam et al., 1979). A hidroxilação deste composto forma o 4hidróxi-N-desmetil-tamoxifeno que, em conjunto com 4-OH-TAM, configuram-se como moléculas de ação antineoplásica. Presume-se que a atividade do 4-OH-TAM seja 30 a 100 vezes superior à do tamoxifeno (Jordan, 2003, 2007).

Parece razoável supormos que os produtos oriundos do metabolismo do tamoxifeno possam exibir efeito leishmanicida, uma vez que demonstramos a eficácia deste fármaco administrado por via intraperitoneal em modelos de roedores infectados com L. (L.) amazonensis, L. (V.) braziliensis e L. (L.) chagasi. Assim, promastigotas de L. amazonensis foram incubados com 4-OH-TAM por 24 horas (Figura 7A). Posteriormente foi determinada $I_{50}$ equivalente a 9,4 $\pm 0,2 \mu \mathrm{M}$. Este valor encontra-se na mesma faixa de concentração estabelecida para tamoxifeno contra todas as espécies testadas (entre 9,0 e 20,0 $\mu$ M, ANEXO A), concentrações em que são observados diversos efeitos independentes da interação com o receptor de estrógeno em células tumorais. Estes resultados levam-nos a especular que a molécula de tamoxifeno não precise necessariamente ser metabolizada a 4-OH-TAM para exibir seu efeito leishmanicida. Uma vez que este metabólito exibe maior avidez por receptores estrogênicos que o próprio tamoxifeno, parece interessante se investir na pesquisa de novas moléculas desenhadas a partir do tamoxifeno, de forma que modificações em sua estrutura evitem sua metabolização.

Paralelamente, realizamos ensaios para verificar a citotoxicidade de 4-OH-TAM. A linhagem LLCMK-2 (células epiteliais de rim de macaco Rhesus) foi utilizada em incubações por 24 horas com concentrações variadas de 4-OH-TAM (Figura 7B). A concentração citotóxica para $50 \%$ da cultura $\left(\mathrm{CC}_{50}\right)$ foi de $19,7 \pm 2,6 \mu \mathrm{M}$, valor aproximadamente 2 vezes maior que a $I_{50}$ verificada para promastigotas de L. (L.) amazonensis. 
A

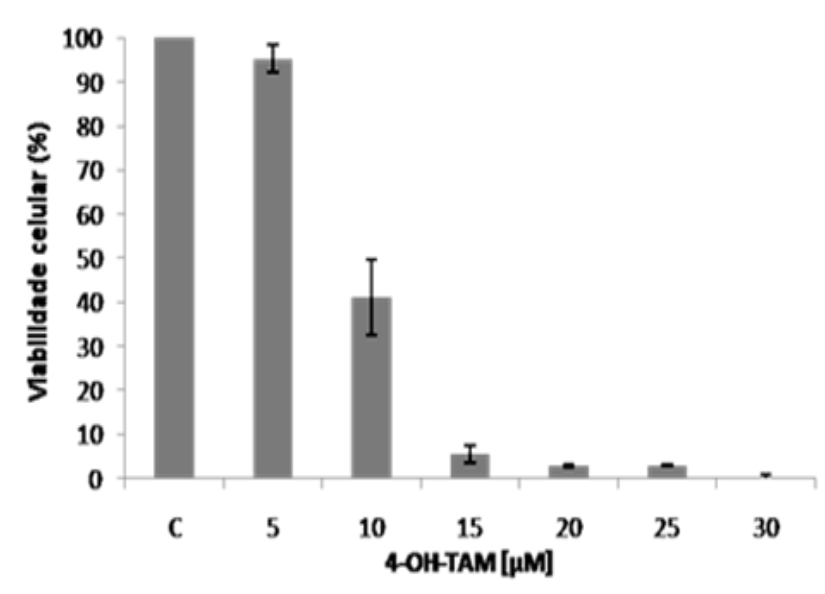

B

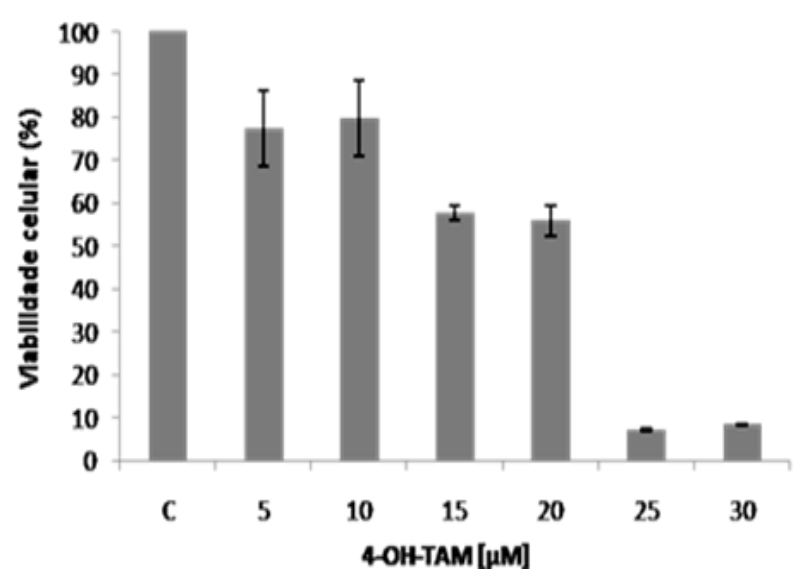

Figura 7. Atividade do metabólito 4-hidróxi-tamoxifeno contra L. (L.) amazonensis e células LLCMK-2 in vitro. Promastigotas (A) ou células LLCMK-2 (B) foram incubados com concentrações crescentes de 4-hidróxitamoxifeno (4-OH-TAM) por 24 horas e a viabilidade celular foi avaliada pelo método colorimétrico de MTT. " $C$ " indica o grupo Controle de células que não recebeu a droga. Os gráficos representam a média de dois experimentos independentes, cada um deles realizado em triplicata. As barras finas indicam o desvio-padrão.

\subsubsection{Efeito leishmanicida de outros SERMs}

Além de propormos a necessidade de investimento na pesquisa de novas moléculas desenhadas a partir do tamoxifeno, sugerimos também a avaliação do efeito de outros SERMs em culturas de Leishmania. Para isso, escolhemos dois compostos dessa família: toremifeno, que também se trata de um trifeniletileno com atividade antiestrogênica, cujo uso no tratamento de câncer de mama avançado em mulheres pós-menopausa já está bem estabelecido; e raloxifeno, um composto benzotiofênico não-esteroidal primeiramente desenvolvido para o tratamento de câncer de mama (Figura 8; revisado em Goldstein et al., 2000). É importante ressaltar que ensaios clínicos utilizando raloxifeno nos últimos anos tem focado a sua atuação contra osteoporose e tratamento de doenças coronarianas e não apenas na prevenção do câncer de mama (revisado em Ali e Coombs, 2002; Park e Jordan, 2002). 
A<smiles>CN(C)CCOc1ccc(C(=C(CCCl)c2ccccc2)c2ccccc2)cc1</smiles>

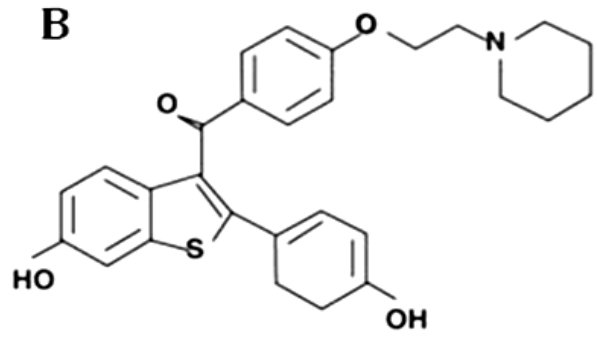

Figura 8. Estrutura química da molécula de toremifeno (A) e raloxifeno (B).

Ensaios de inibição de culturas de promastigotas de L. (L.) amazonensis com toremifeno foram conduzidos e o valor de $\mathrm{IC}_{50}$ encontrado $(28,6 \pm 1,7 \mu \mathrm{M})$ está na mesma faixa de concentração daquele determinado para o tamoxifeno contra esta mesma espécie. Estendemos o estudo para a atividade do raloxifeno contra diferentes espécies, conforme mostrado na Tabela 2. Nossos resultados indicam que raloxifeno é capaz de inibir a multiplicação dos parasitas com concentrações inibitórias para 50\% da cultura entre 30 e 40 $\mu \mathrm{M}$, aproximadamente. Também foi demonstrado que raloxifeno possui efeito inibitório tanto para amastigotas de L. (L.) amazonensis ( $\left(\mathrm{C}_{50}: 15,0 \pm 2.3 \mu \mathrm{M}\right)$ quanto amastigotas intracelulares de L. (L.) amazonensis, já que infecções de parasitas em macrófagos de peritônio tratadas apresentaram redução significativa nas taxas de infecção (Figura 9).

Tabela 2 - Valores de $\mathrm{IC}_{50}$ de raloxifeno $(\mu \mathrm{M})$ para culturas de promastigotas de Leishmania spp.

\begin{tabular}{|l|l|}
\hline L. (L.) amazonensis* & $30,2 \pm 1,7$ \\
\hline L. (V.) braziliensis & $38,0 \pm 8,4$ \\
\hline L. (L.) chagasi & $30,9 \pm 0,5$ \\
\hline L. (L.) donovani & $32,5 \pm 1,3$ \\
\hline L. (L.) major & $32,6 \pm 1,4$ \\
\hline L. (L.) mexicana & $30,3 \pm 1,3$ \\
\hline
\end{tabular}

*Culturas incubadas por $24 \mathrm{~h}$. A viabilidade foi avaliada pelo método colorimétrico de MTT. 


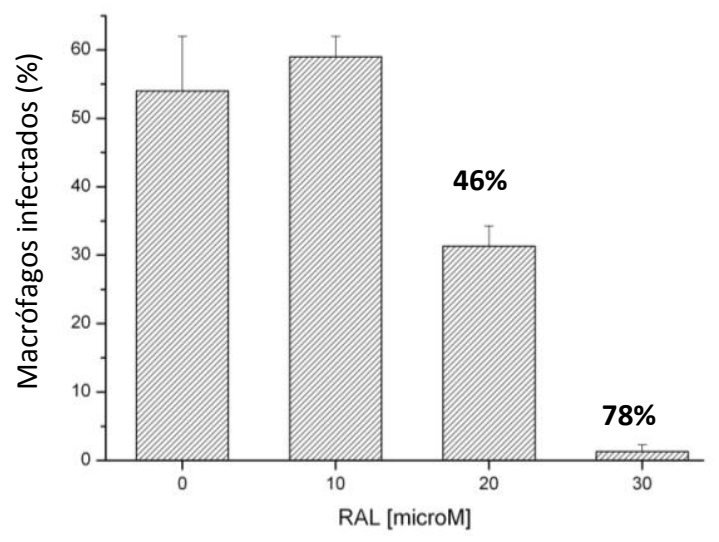

Figura 9. Efeito de raloxifeno (RAL) na multiplicação de amastigotas intracelulares. Macrófagos peritoniais foram infectados com promastigotas de L. (L.) amazonensis na proporção de 4 parasitas: 1 macrófago. Após a infecção foram adicionadas as concentrações indicadas de RAL por 48h. As porcentagens de infecção foram obtidas após contagem de 100 macrófagos/ lamínula em triplicata. Os números acima das barras indicam a redução nas taxas de infecção em relação ao grupo não-tratado.

Não existem relatos na literatura que descrevam a utilização de moduladores seletivos do receptor de estrógeno contra protozoários tanto in vitro como in vivo. Os resultados obtidos indicam que raloxifeno apresenta importante efeito leishmanicida in vitro, assim como tamoxifeno. Entretanto, nossos resultados in vivo demonstraram que a administração de $40 \mathrm{mg} / \mathrm{kg} /$ dia de raloxifeno via intraperitoneal não foi tão eficaz na redução da lesão de camundongos BALB/C infectados com L. (L.) amazonensis. Apesar de levar a uma ligeira diminuição na progressão da lesão (Figura 10), os ensaios apresentados anteriormente mostram que tamoxifeno retardou a progressão das lesões e úlceras de forma mais acentuada. 


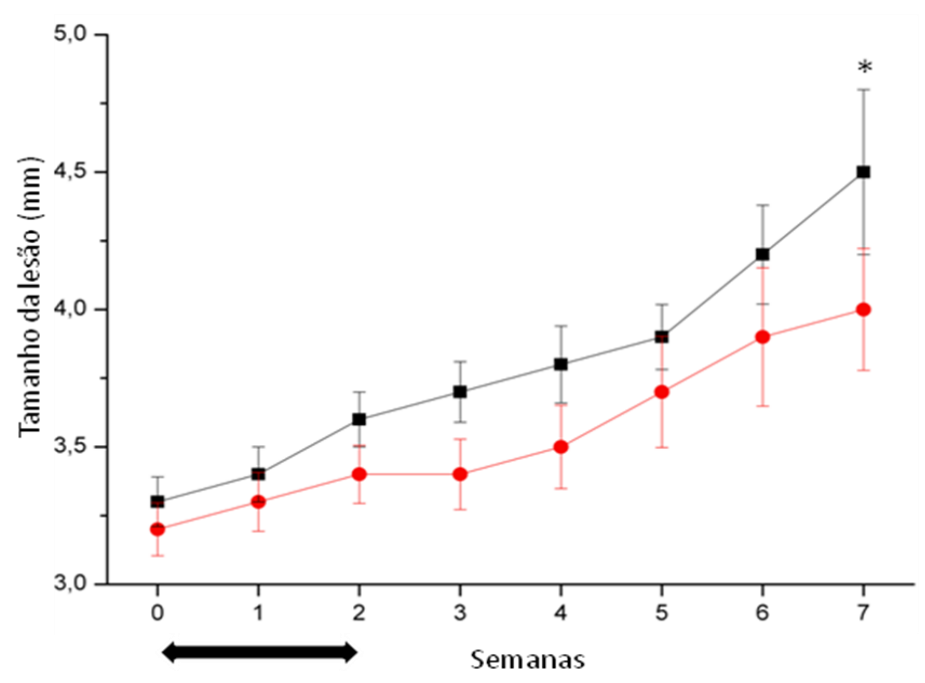

Figura 10. Evolução do diâmetro médio das lesões de camundongos BALB/c infectados com promastigotas de L. (L.) amazonensis. A curva vermelha indica a progressão das lesões para animais que receberam 40 $\mathrm{mg} / \mathrm{kg} /$ dia de raloxifeno via intraperitoneal por 15 dias (seta preta) e a curva preta indica a média do tamanho da lesão dos animais do grupo controle. $\left({ }^{*}\right) \mathrm{P}=0,001 ; n=6 /$ grupo. $O$ tratamento (período indicado pela seta) foi iniciado após estabelecimento de lesão (30 a 45 dias pós-infecção).

\subsubsection{Sensibilidade de isolados de pacientes ao tamoxifeno}

Os resultados descritos até este momento dizem respeito à avaliação da sensibilidade de cepas-referência para diversas espécies de Leishmania ao tamoxifeno. Nossas cepas de parasitas foram mantidas em nosso laboratório, ora por repiques sucessivos de culturas de promastigotas ora por inoculação em animais de experimentação. Após obtermos resultados promissores quanto à eficácia do tamoxifeno contra estes parasitas, propusemos avaliar se parasitas circulantes em áreas endêmicas também apresentariam este fenótipo de suscetibilidade ao fármaco in vitro. Uma nova linha de trabalho foi iniciada em nosso grupo e, após realizarmos a descrição do perfil de sensibilidade de isolados de pacientes com leishmaniose cutânea às drogas comumente utilizadas na prática clínica: Glucantime ${ }^{\circledR}$ e anfotericina B (Zauli-Nascimento et al., 2010), demonstramos a suscetibilidade tanto destes quanto de novos isolados de pacientes com leishmaniose visceral ao tamoxifeno. Os resultados foram publicados na sessão Letters to the Editor em periódico científico especializado ("Clinical isolates of New World Leishmania from cutaneous and visceral 
leishmaniasis patients are uniformly sensitive to tamoxifen", ANEXO D). Resumidamente, estes dados mostram que 19 isolados de campo de L. (L.) chagasi, L. (V.) braziliensis e L. (L.) amazonensis são suscetíveis ao tamoxifeno, com concentrações inibitórias dentro da mesma faixa observada para nossas cepas de laboratório. A homogeneidade detectada para a suscetibilidade à droga oferece um embasamento mais sólido para justificar testes com tamoxifeno em futuros ensaios clínicos.

\subsubsection{Atividade tripanossomicida de tamoxifeno in vitro $e$ in vivo}

Espécies do gênero Trypanosoma também fazem parte da família Trypanosomatidae e são consideradas geneticamente relacionadas aos parasitas do gênero Leishmania. As similaridades incluem inúmeras enzimas participantes de rotas metabólicas altamente conservadas, comprovadas tanto por análises comparadas de seus respectivos genomas como por estudos bioquímicos (El-Sayed et al., 2005; Landfear, 2008; Stuart et al., 2008). Dada a atividade bem estabelecida de tamoxifeno contra Leishmania, decidimos averiguar o potencial tripanossomicida de tamoxifeno para diferentes formas do ciclo biológico de Trypanosoma cruzi, incluindo amastigotas intracelulares, epimastigotas e tripomastigotas de culturas, além de animais experimentalmente infectados com o parasita. Valores de $I_{50}$ e curvas de parasitemia foram determinados e os dados estão descritos no artigo científico "The anticancer drug tamoxifen inhibits the growth of Trypanosoma cruzi in vitro but is ineffective in the resolution of the acute form of Chagas disease in mice" (ANEXO E). Apesar de detectarmos atividade inibitória in vitro, observamos que este fármaco é ineficaz na resolução de infecções experimentais agudas de camundongos suíços e BALB/c por T. cruzi. 


\subsection{Investigação de mecanismos de ação do tamoxifeno em $L$. (L.) amazonensis}

\subsubsection{Tamoxifeno não atua como um modulador seletivo de receptor de estrógeno - SERM contra Leishmania}

Os dados disponíveis na literatura sobre os efeitos do tamoxifeno em células tumorais incluem uma variedade de alvos metabólicos. Entretanto, optamos por avaliar previamente se sua ação sobre o parasita poderia ser explicada graças à sua capacidade de atuar como um SERM.

Primeiramente, realizamos buscas por sequências similares a do receptor de estrógeno de mamíferos na base de dados do genoma de Leishmania (GeneDB, www.genedb.org), porém, nenhuma sequência correspondente foi identificada. Ainda assim, optamos por descartar qualquer atividade do tamoxifeno relacionada à sua interação com um receptor putativo incubando tanto promastigotas quanto amastigotas de L. (L.) amazonensis na presença de 17-ß-estradiol ou 17-ß-estradiol combinado ao tamoxifeno em concentrações equimolares. A incubação com o hormônio não levou a alteração na viabilidade dos parasitas, ao passo que na presença deste com tamoxifeno, foi verificado o mesmo perfil de inibição dos parasitas obtido para incubação apenas com tamoxifeno. Portanto, acreditamos que o efeito leishmanicida deste fármaco não esteja relacionado à sua interação com a maquinaria do receptor de estrógeno, conforme demonstrado na seção Results do artigo "Tamoxifen is effective against Leishmania and induces a rapid alkalinization of parasitophorous vacuoles harbouring Leishmania (Leishmania) amazonensis amastigotes" (ANEXO A). 


\subsubsection{Tamoxifeno não altera os níveis de óxido nítrico (NO) em infecções in vitro}

Outro aspecto avaliado baseou-se em descrições na literatura que mostram que tamoxifeno, em concentrações na faixa micromolar, atua como potente indutor da atividade da enzima NO sintase (Loo et al., 1998). O NO é uma molécula reconhecidamente crucial na defesa antimicrobiana do macrófago e sua liberação está intimamente relacionada ao controle da infecção por patógenos intracelulares como Mycobacterium tuberculosis, Salmonella e Leishmania (revisado em Das et al., 2010). O fato de tamoxifeno ser capaz de modular a produção levou-nos a especular se seu efeito leishmanicida poderia ser explicado graças à atividade microbicida do NO em macrófagos tratados. Para averiguarmos se esta hipótese seria correta coletamos frações do sobrenadante de culturas de macrófagos de peritônio em diferentes períodos de infecção $(2,24$ e 48 h) para quantificação direta de nitrito pela Reação de Griess. Não foi possível detectar acúmulo de nitrito em macrófagos tratados com tamoxifeno (Figura $11 \mathrm{~A}$ e dados discutidos no artigo "Tamoxifen is effective in the treatment of Leishmania amazonensis infections in mice"; ANEXO C).

O fato de não detectarmos NO pela metodologia utilizada não descarta necessariamente que tamoxifeno não tenha induzido a atividade da NO sintase em macrófagos infectados e tratados. Assim, outra abordagem foi utilizada com o intuito de avaliarmos possíveis alterações nos níveis da enzima NO sintase induzida (iNOs) em infecções macrofágicas após incubação com tamoxifeno. Para isso, extratos proteicos de macrófagos não-infectados ou infectados e incubados na presença ou na ausência do fármaco foram obtidos para detecção da abundância de iNOS por Western blot.

Basicamente, macrófagos diferenciados de medula óssea de camundongos BALB/c foram incubados com ou sem estímulo (LPS + interferon-gama) por $3 \mathrm{~h}$ para posterior infecção com amastigotas de L. (L.) amazonensis (5 parasitas por macrófago) por 1 h. Após este período as células lavadas foram incubadas com 15 ou $30 \mu \mathrm{M}$ de tamoxifeno por $3 \mathrm{~h}$ (Figura 11B). Podemos observar na Figura 11B que macrófagos pré-estimulados com LPS + interferongama foram capazes de expressar iNOS. O tratamento com tamoxifeno das células estimuladas não resultou em aumento da expressão de iNOS. Por outro lado, células tratadas 
apenas com tamoxifeno não apresentaram expressão detectável da proteína iNOS em nenhuma das concentrações utilizadas, levando-nos a descartar o papel do NO como responsável pela controle da infecção in vitro após tratamento. Os experimentos descritos nesta etapa foram conduzidos durante o período de estágio de "Doutorado-sanduíche" realizado no laboratório da Dra. Norma Andrews, Universidade de Maryland, Estados Unidos.

A

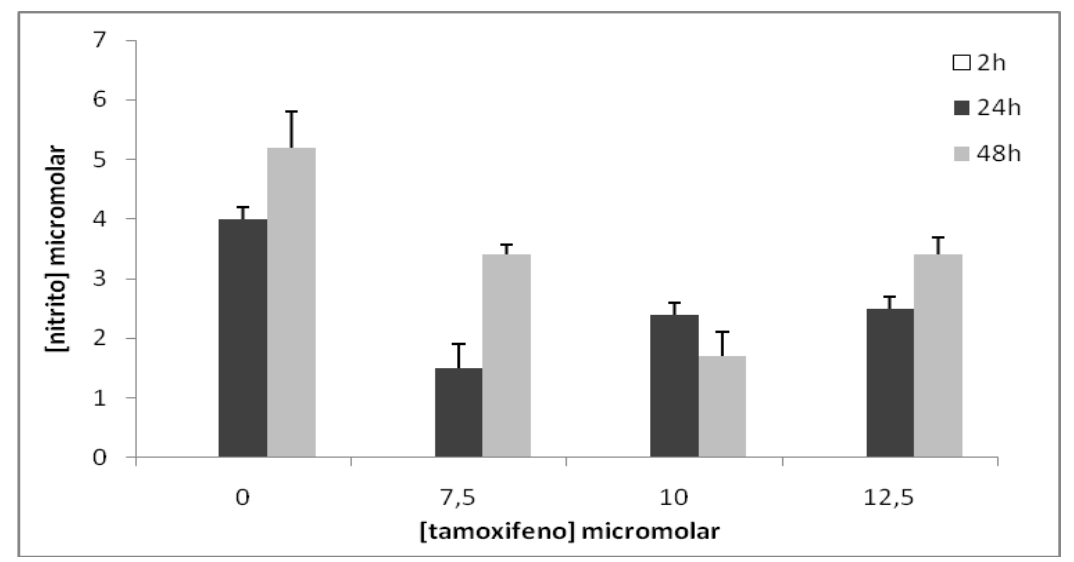

B

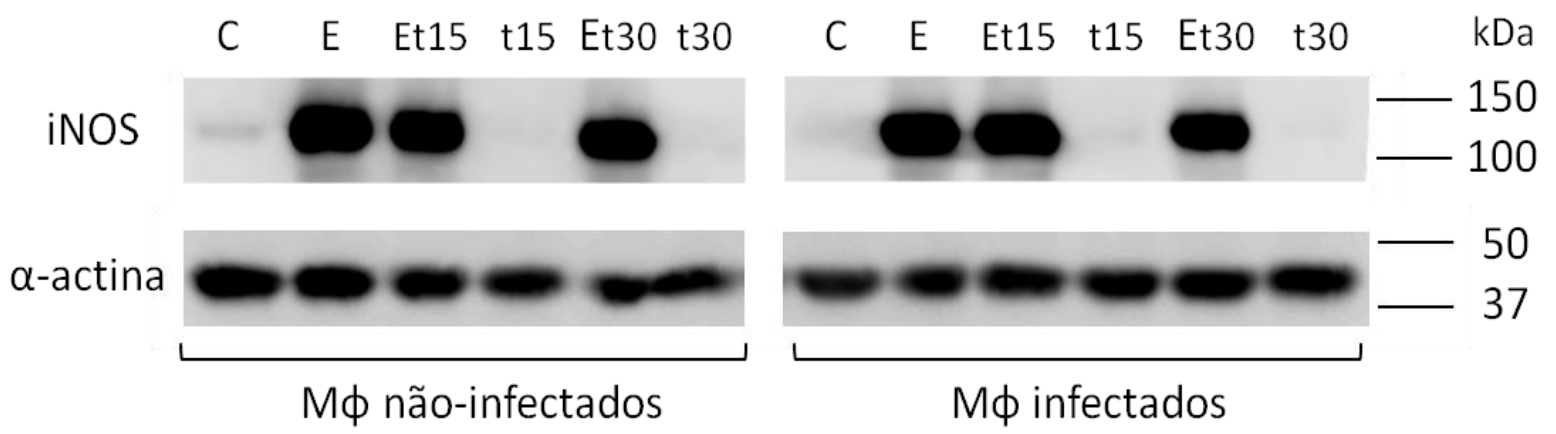

Figura 11. Detecção de nitrito e da proteína iNOS em infecções de macrófagos. A: Infecções in vitro de macrófagos de peritônio com promastigotas de L. (L.) amazonensis foram realizadas (3 parasitas por macrófago) para tratamento com doses crescentes de tamoxifeno (7,5; 10 e 12,5 $\mu \mathrm{M})$ por 2, 24 e $48 \mathrm{~h}$. Após cada período, o sobrenadante de cada cultura foi dosado quanto à presença de nitrito pela Reação de Griess. B: Extratos totais de proteína de $2 \times 10^{6}$ macrófagos derivados de medula óssea $(\mathrm{M} \phi)$ de camundongos BALB/c não infectados (esquerda) ou infectados com amastigotas de $L$. (L.) amazonensis (5 parasitas por macrófago; direita) foram incubados com o anticorpo primário anti-iNOS (1:10.000). As células foram pré-estimuladas com LPS + interferon-gama ("E") por $1 \mathrm{~h}$ ou não ("C") e tratadas com 15 ou $30 \mu \mathrm{M}$ de tamoxifeno ("t15" ou "t30") por 3h. Como controle de eficiência da transferência e de quantidade de proteína por canaleta foi utilizado o anticorpo anti- $\alpha$-actina $(1: 5.000)$. 


\subsubsection{Tamoxifeno alcaliniza vacúolos fagolisossômicos parasitados por L. (L.) amazonensis}

Conforme descrito anteriormente, tamoxifeno exibiu um potente efeito na eliminação de amastigotas intracelulares de L. (L.) amazonensis. A partir destes e de resultados descritos em outros estudos (Altan et al., 1998, 1999; Chen et al., 1999), que demonstraram a propriedade desta molécula de inibir a acidificação de organelas intracelulares, decidimos investigar se o efeito do tamoxifeno estaria relacionado à modulação do $\mathrm{pH}$ de vacúolos de macrófagos infectados com L. (L.) amazonensis.

Nossos resultados mostram que o tratamento com $10 \mu \mathrm{M}$ de tamoxifeno induziu rapidamente a alcalinização de vacúolos de macrófagos peritoniais contendo amastigotas de L. (L.) amazonensis, sendo este um efeito já observado a partir de 30 minutos até 24 h após a incubação com a droga. As alterações foram detectadas a partir da monitoração do $\mathrm{pH}$ de vacúolos de macrófagos infectados e corados com laranja de acridina ou incubados com a sonda colorimétrica SNAFL-calcein AM, por microscopia confocal. A alcalinização dos vacúolos parece não estar diretamente relacionada à morte dos parasitas pela alteração imediata das condições ideais do meio necessário à sobrevivência das formas amastigotas, mas sim ligada ao aumento do efeito leishmanicida de tamoxifeno, uma vez que este composto apresentouse mais ativo na faixa de $\mathrm{pH}$ neutro a moderadamente alcalino. A descrição detalhada e as implicações deste efeito para a manutenção das infecções são apresentadas no artigo "Tamoxifen is effective against Leishmania and induces a rapid alkalinization of parasitophorous vacuoles harbouring Leishmania (Leishmania) amazonensis amastigotes" (ANEXO A).

Após descartamos a indução de NO e a alcalinização de vacúolos fagolisossômicos como possíveis mecanismos de ação do tamoxifeno contra Leishmania, optamos por avaliar a influência deste fármaco na biossíntese de dois grandes grupos de moléculas imprescindíveis para o parasita: os isoprenoides e os esfingolipídios, conforme detalhado a seguir. 


\subsubsection{Interferência do tamoxifeno no metabolismo de isoprenoides de Leishmania}

Diversos trabalhos de Wiseman e colaboradores identificaram similaridades estruturais entre as moléculas de tamoxifeno, 4-hidróxi-tamoxifeno, colesterol e ergosterol, concluindo que tanto o fármaco como seu principal metabólito (4-hidróxi-tamoxifeno) são capazes de mimetizar as moléculas de colesterol e ergosterol em modelo in vitro de bicamada lipídica (Wiseman et al., 1990, 1992). Tal observação nos levou a averiguar se tamoxifeno seria capaz de interferir na via de biossíntese de isoprenoides em Leishmania já que o ergosterol - e não o colesterol - é o principal esterol de membranas em Leishmania e sua biossíntese ocorre como resultado do metabolismo de isoprenoides (Ginger et al., 2001). Essa via metabólica, presente na maior parte dos organismos eucariotos, é responsável pela síntese de colesterol, ergosterol, dolicóis, ubiquinona, geraniol, farnesol, grupos prenil transferidos a proteínas, entre outros isoprenoides (Faust et al., 1979; Chojnacki e Dallner, 1988, revisado em Miziorko, 2011).

Santa Cruz e colaboradores verificaram que a síntese de dolicol (isoprenóide carreador de açúcares) é inibida de forma significativa quando células da linhagem neoplásica T47D são tratadas com tamoxifeno em concentrações na faixa de microMolar (Santa Cruz et al., 1985). Somado a isso, estudos demonstraram que $10 \mu \mathrm{M}$ de tamoxifeno é capaz de modular a transferência do grupo farnesil a proteínas de células tumorais MCF-7, já que potencializa a ação do composto SCH66336, um inibidor da proteína farnesiltransferase (Basso et al., 2005), levando ao comprometimento da farnesilação de proteínas específicas desta linhagem tumoral.

A ubiquinona é outro produto crucial da rota de síntese dos isoprenoides. Trata-se de uma coenzima ( $\mathrm{CoQ}$ ) que atua como aceptora de elétrons na cadeia respiratória mitocondrial. Um grande número de trabalhos tem demonstrado a função da CoQ na inibição da ativação de eventos de morte celular programada tipo apoptose em células de mamíferos. A CoQ está relacionada à prevenção de eventos apoptóticos desencadeados por irradiação de laser e por inibição da despolarização da membrana mitocondrial (Papucci et al., 2003). Além disso, Navas e colaboradores demonstraram que a CoQ é capaz de impedir a ativação de caspase 3 
dependente de ceramida, sendo essa uma molécula de extrema relevância para a sinalização efetora do evento de morte celular programada (Navas et al., 2002). Outro estudo também verificou que a CoQ atua como um potente antioxidante capaz de prevenir contra o estresse oxidativo celular a partir de uma relação direta com a diminuição da ceramida (Lopez-Lluch et al., 1999).

Sabendo que os compostos isoprênicos estão intimamente relacionados a diversos processos biológicos, inclusive participando da organização estrutural do parasita, e que a função de algumas destas moléculas pode ser modulada pelo tamoxifeno, propusemos avaliar a interferência deste na biossíntese dos isoprenoides. Nossa estratégia baseou-se na incorporação do aminoácido leucina marcado radioativamente em diversos produtos finais desta via, como geraniol, farnesol, ergosterol, dolicol e ubiquinona, já que Ginger e colaboradores determinaram previamente que 70 a $80 \%$ do ergosterol de L. (L.) amazonensis provem da via da leucina (Ginger et al., 1999).

Após extração dos lipídios neutros de promastigotas tratados com crescentes concentrações de tamoxifeno e incubados com $\left[{ }^{14} \mathrm{C}\right]$-leucina por $24 \mathrm{~h}$, realizamos a análise da biossíntese dos produtos finais da via por duas metodologias distintas: cromatografia em camada delgada (HPTLC) e cromatografia líquida de alta performance (HPLC). Moléculas com Rfs equivalentes a dos padrões de ergosterol, farnesol, geraniol, dolicol e CoQ foram separadas por HPTLC (Figura 12A) tanto para o grupo de parasitas não tratados (Controle) como para o grupo que recebeu $10 \mu \mathrm{M}$ de tamoxifeno. No caso do grupo tratado com tamoxifeno, observamos que as bandas detectadas apresentam menor intensidade quando comparadas às bandas do grupo de parasitas não tratados. O efeito do tratamento com tamoxifeno também foi verificado por HPLC, na qual se notou diminuição significativa da incorporação de leucina em dolicol (55 e 60 carbonos) e ergosterol (Figura 12B). Os valores aproximados de redução na incorporação de leucina em parasitas tratados estão apresentados para os dois métodos utilizados na Figura 12C. A análise dos picos de retenção dos compostos farnesol e geraniol não foi possível, pois, para o sistema de eluentes empregado, estes picos são eluídos em conjunto com o pico de injeção da amostra.

Com base nos resultados obtidos, podemos afirmar que houve redução global na biossíntese de isoprenoides quando os parasitas são incubados com tamoxifeno. Entretanto, o 
efeito inibitório observado foi discreto e comum a todos os produtos desta via analisados. Como a leucina é o principal precursor de isoprenoides em Leishmania, os resultados obtidos podem indicar que o efeito sobre essa via metabólica seja na verdade secundário e decorrente de um estresse global do parasita desencadeado pela droga por um mecanismo distinto.

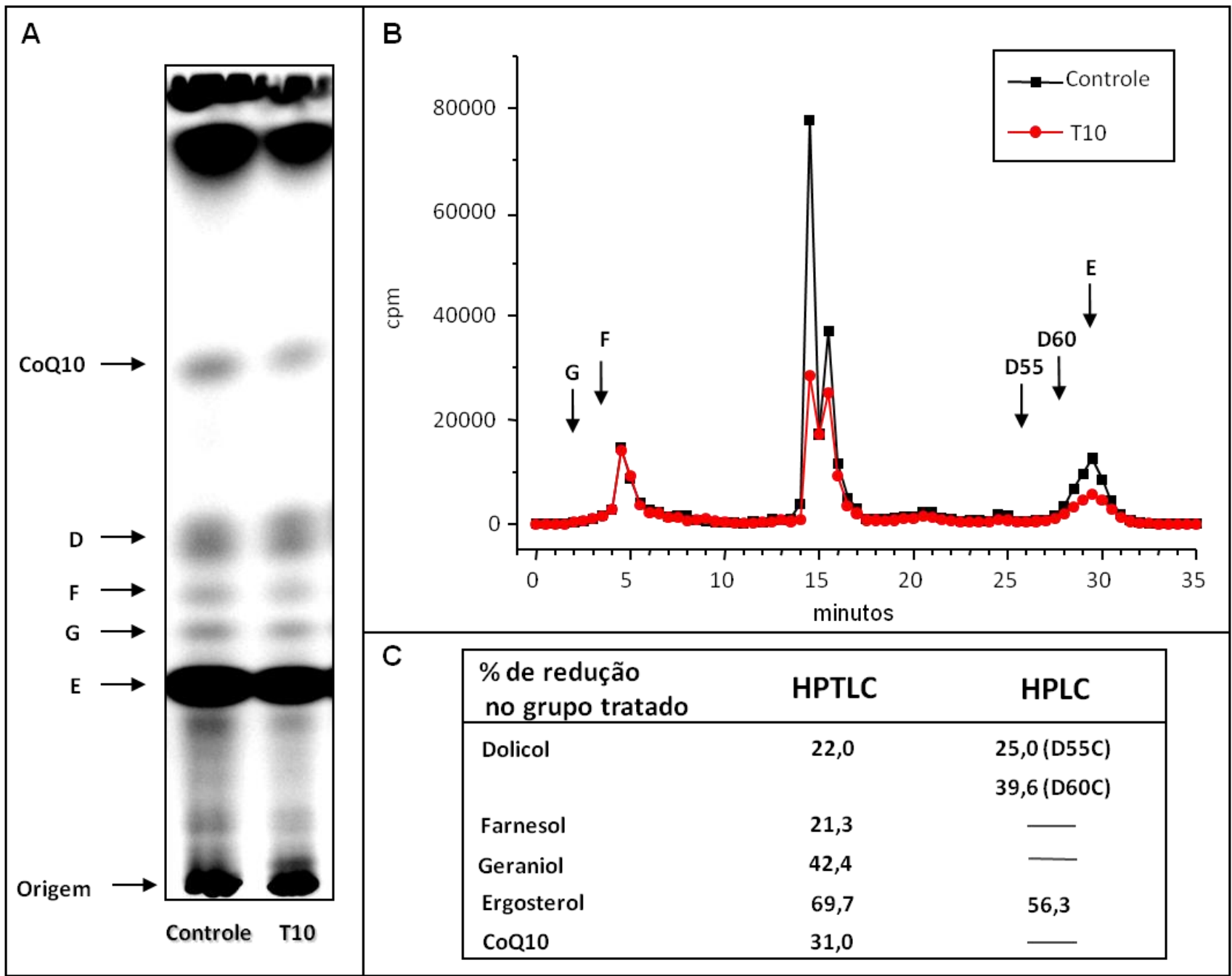

Figura 12. Biossíntese de isoprenoides em promastigotas de L. (L.) amazonensis tratados com tamoxifeno. Cerca de $5 \times 10^{8}$ promastigotas de L. (L.) amazonensis foram incubados na ausência ou na presença de $10 \mu \mathrm{M}$ de tamoxifeno por $2 \mathrm{~h}$ e em seguida foi adicionado $50 \mu \mathrm{Ci} / \mathrm{mL}$ de $\mathrm{L}-\left[\mathrm{U}-{ }^{14} \mathrm{C}\right]$-leucina marcação radioativa por mais $22 \mathrm{~h}$. As amostras foram lavadas e liofilizadas. Os extratos lipídicos neutros dos parasitas marcados foram extraídos e secos sob corrente de nitrogênio. As frações lipídicas foram congeladas a $-20{ }^{\circ} \mathrm{C}$. Alíquotas de cada extrato foram analisadas por HPTLC (A) ou HPLC (B). Controle: parasitas não tratados; T10: promastigotas tratados com $10 \mu \mathrm{M}$ de tamoxifeno por $24 \mathrm{~h}$. As análises foram realizadas utilizando-se o mesmo número de parasitas nas amostras controle e tratadas. Os valores de $\mathrm{R} f$ e tempos de retenção dos padrões estão indicados por setas: $\mathrm{E}$, ergosterol; G, geraniol; F, farnesol; D, dolicol com 55 e 60C e CoQ, coenzima Q7-10. (C) Porcentagem de redução na incorporação de leucina em diferentes produtos para parasitas tratados em relação ao grupo controle não-tratado. 


\subsubsection{Tamoxifeno permeabiliza a membrana plasmática de promastigotas de L. (L.) amazonensis}

Diversos estudos relataram a interação de tamoxifeno com membranas biológicas graças às propriedades químicas decorrentes da sua estrutura. Trata-se de uma molécula reconhecidamente lipofílica (coeficientes de partição $\geq 5,0$ ) capaz de particionar com alta eficiência em composições lipossomais, membranas mitocondriais, bicamadas sintetizadas a partir de di-miristoil-fosfatidilcolina, entre outros modelos (Custódio et al., 1991; Luxo et al., 2003). Esta interação é modulada por uma série de fatores como: concentração da droga, composição da membrana, temperatura e presença de colesterol (Custódio et al., 1991). CruzSilva e colaboradores também mostraram que tamoxifeno pode induzir perturbações de ordem estrutural em eritrócitos dada sua alta partição naquela membrana (Cruz-Silva et al., 2000). Apesar de existirem estudos avaliando a interação e os efeitos de tamoxifeno em membranas biomiméticas, sua interferência na morfologia e ultraestrutura de seres unicelulares não é bem conhecida. Luxo e colaboradores utilizaram uma linhagem de Bacillus stearothermophilus como modelo para estudar alterações induzidas pelo tamoxifeno na estrutura celular. Os autores verificaram que, entre outros efeitos, tamoxifeno promoveu fraturas na membrana celular confirmando se tratar de uma droga "membrana-ativa" cujo efeito possa estar relacionado aos mecanismos moleculares que desencadeiam a morte celular (Luxo et al., 2003).

Com base na íntima interação do tamoxifeno com membranas, decidimos avaliar se o mesmo seria capaz de permeabilizar a membrana plasmática de promastigotas de L. (L.) amazonensis. Para isso, utilizamos a estratégia de incubação de culturas de parasitas com iodeto de propídio (IP), um agente fluorescente para o qual membranas plasmáticas íntegras são impermeáveis, mas que é capaz de penetrar membranas celulares permeabilizadas e intercalar no material genético da célula (Brohem et al., 2009). Culturas incubadas em PBS/glicose receberam ou não tamoxifeno (10 e $20 \mu \mathrm{M})$ ou saponina 0,025\% em três diferentes tempos: 0 (momento da análise), 30 ou 90 minutos. Após a incubação, as células foram analisadas por citometria de fluxo quanto à incorporação de IP $(0,5 \mu \mathrm{g} / \mathrm{mL})$ adicionado 
no momento da análise. Na Figura 13 podemos observar que a proporção de células IPpositivas tanto no grupo controle quanto nos grupos que receberam tamoxifeno no momento da análise (tempo 0) foi baixa ( $\leq 5 \%)$. Entretanto, houve incremento de aproximadamente 40 e 70\% nas populações de parasitas IP-positivas quando estas foram incubadas por 30 minutos com tamoxifeno 10 e $20 \mu \mathrm{M}$, respectivamente. Podemos notar que tamoxifeno desencadeou a permeabilização da membrana plasmática de promastigotas de Leishmania ao IP em 30 minutos de incubação de forma dose-dependente. Para o período de 90 min também foi verificado que as células permeabilizadas representam 65 e $70 \%$ da população IP-positiva (Figura 13) e, portanto, não houve diferença significativa quanto ao aumento de incorporação de IP quando o tempo de incubação com a droga foi prolongado por mais uma hora (90 minutos). Resultados previamente obtidos indicam que incubações com 10 e $20 \mu \mathrm{M}$ de tamoxifeno por $2 \mathrm{~h}$ levam a 50 e $70 \%$ de inibição de viabilidade de culturas de promastigotas, respectivamente. Apesar de observarmos a redução da viabilidade celular e permeabilização após o tratamento com tamoxifeno, nossas imagens de microscopia eletrônica (item 4.2.5) não revelaram indícios de ruptura da membrana plasmática para $2 \mathrm{~h}$ de incubação.

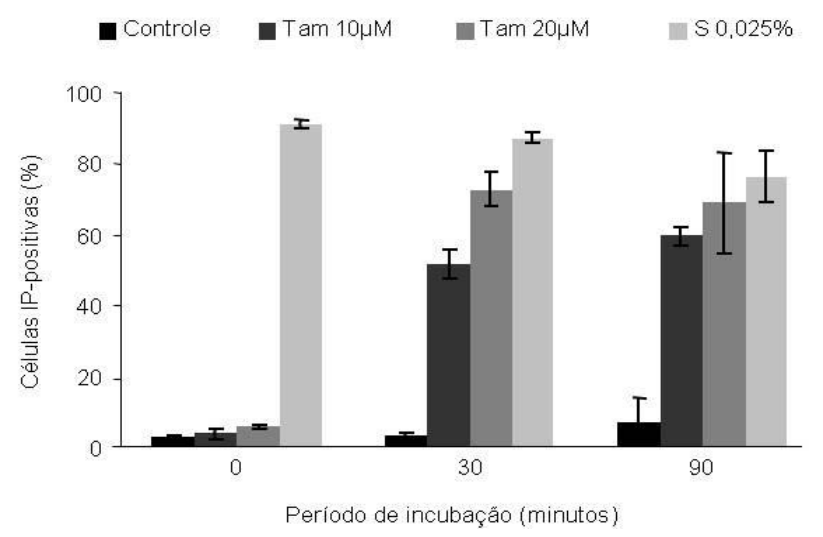

Figura 13. Tamoxifeno altera a permeabilidade da membrana plasmática de promastigotas de $L$. (L.) amazonensis. Aproximadamente $5 \times 10^{6}$ promastigotas de fase logarítmica foram incubados em PBSglicose $1 \mathrm{~g} / \mathrm{L}$ na ausência ou na presença de 10 e $20 \mu \mathrm{M}$ de tamoxifeno por diferentes tempos $(0,30$ e 90 minutos). Finalizada a incubação, as células foram analisadas por citometria de fluxo quanto à incorporação de iodeto de propídio $(0,5 \mu \mathrm{g} / \mathrm{mL})$ adicionado no momento da análise. $O$ detergente saponina (S) 0,025\% foi utilizado como controle de permeabilidade de membrana.

Possivelmente o efeito descrito acima levaria à perda da integridade da membrana plasmática do parasita, causando perturbações de natureza bioquímica e/ou biofísica, fato que poderia desencadear sua morte. Estudos realizados por Engelke e colaboradores 
demonstraram, por meio de uma série de parâmetros físico-químicos (calorimetria diferencial de varredura, anisotropia fluorescente e polarização generalizada - Laurdan), que tamoxifeno perturba a estrutura da bicamada lipídica de estruturas multi- e unilamelares. Além disso, concluíram que tamoxifeno altera a permeabilidade das vesículas lipídicas e induz a formação de fendas transientes na bicamada. Os dados obtidos pelo grupo reforçam ainda a hipótese de que esta molécula localiza-se imersa no folheto externo da bicamada (Engelke et al., 2001).

Iniciamos, dessa forma, estudos para verificar se tamoxifeno está integrado na membrana plasmática dos parasitas. Ensaios preliminares apontam que parte das moléculas de tamoxifeno parece permanecer integrada na fração de membranas (FM) de parasitas obtida após tratamento com a droga por 30 min (Figura 14). Os lipídios totais desta fração e de outra denominada fração citosólica (FC) foram separados por HPTLC. Tamoxifeno foi identificado a partir da detecção da banda referente ao padrão de tamoxifeno puro por exposição da placa à luz UV (onda curta). Na Figura 14 podemos observar para extratos tratados da FM e FC uma banda com R $f$ correspondente àquele verificado para o padrão de tamoxifeno. Estes resultados devem ser confirmados para diferentes tempos de incubação com diferentes concentrações de tamoxifeno, e as FM e FC devem ser caracterizadas quanto à pureza das amostras para verificar se há contaminação da fração de membranas com componentes citosólicos e vice-versa.

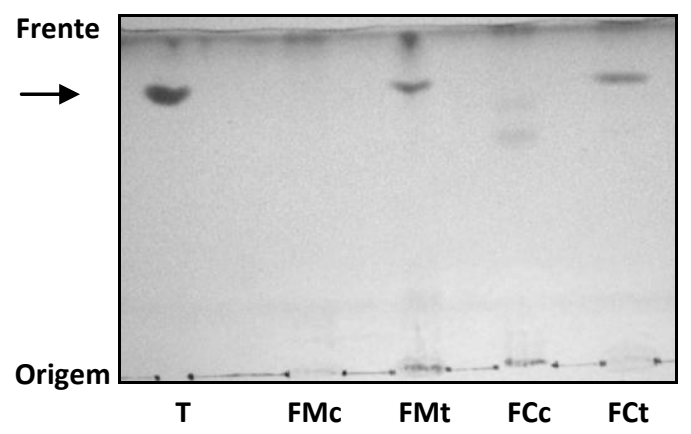

Figura 14. Detecção de tamoxifeno em fração de membranas e citosólica de parasitas. $5 \times 10^{8}$ promastigotas de L. (L.) amazonensis foram incubadas em PBS-glicose $1 \mathrm{~g} / \mathrm{L}$ na ausência (c) ou na presença de $20 \mu \mathrm{M}$ de tamoxifeno (t) por 30 min. Extratos lipídicos de frações enriquecidas de membranas (FM) ou citosólica (FC) foram obtidos após extração com clorofórmio:metanol:solução de Hanks/EDTA 10 mM (1:1:0,75; v:v:v). Os extratos foram submetidos à HPTLC com clorofórmio:metanol:água (60:35:8, v:v:v) para corrida de $2 \mathrm{~cm}$ e o restante em clorofórmio:metanol:ácido acético (90:2:8, v:v:v). A banda referente ao tamoxifeno foi visualizada por exposição da placa à luz UV (onda curta). "T" refere-se ao padrão de tamoxifeno puro. 


\subsubsection{Tamoxifeno altera a morfologia e ultraestrutura de promastigotas de L. (L.) amazonensis}

Sabendo que tamoxifeno é capaz de permeabilizar a membrana plasmática e parece intercalar em frações membranares de promastigotas, nós optamos por investigar os aspectos morfológicos e ultraestruturais de parasitas tratados, de modo a identificar possíveis sinais que justificariam o efeito leishmanicida do fármaco.

Primeiramente foram preparados esfregaços de culturas de L. (L.) amazonensis em lâminas para análise por microscopia de luz. As imagens obtidas são apresentadas na Figura 15, na qual podemos verificar que células que não receberam tratamento (Figura 15A e B) apresentam aspecto típico das formas promastigotas. Por outro lado, grande parte das células que foi incubada com tamoxifeno $10 \mu \mathrm{M}$ (Figura 15C) ou $20 \mu \mathrm{M}$ (Figura 15D) por 30 minutos revela alterações morfológicas caracterizadas por arredondamento do corpo celular sendo que, em muitos casos, este apresenta um "espaço" hialino no interior. Mesmo em células apresentando este formato atípico, o flagelo permaneceu aparentemente inalterado. Nas Figuras 15E e 15F são apresentadas as imagens dos parasitas incubados com 10 e $20 \mu \mathrm{M}$ de tamoxifeno, respectivamente, por 90 minutos e que revelam alterações semelhantes às verificadas em incubações por 30 minutos.

Aparentemente tamoxifeno levou a uma desorganização citoplasmática e mudança do formato celular, acompanhados por uma visível alteração do volume celular. Alguns trabalhos na literatura descrevem perfis similares, como para incubações de culturas de promastigotas de Leishmania com soro humano ou nitroprussiato de sódio (Barral-Neto et al., 1987; Genestra et al., 2008). No entanto, nossos achados não permitem uma conclusão direta acerca de um possível mecanismo que levaria a este tipo de alteração morfológica na forma promastigota, permitindo-nos apenas afirmar que nas doses de tamoxifeno empregadas por estes períodos de incubação há ocorrência de estresse celular sem ocorrência de células lisadas ou com estrutura membranar danificada. 


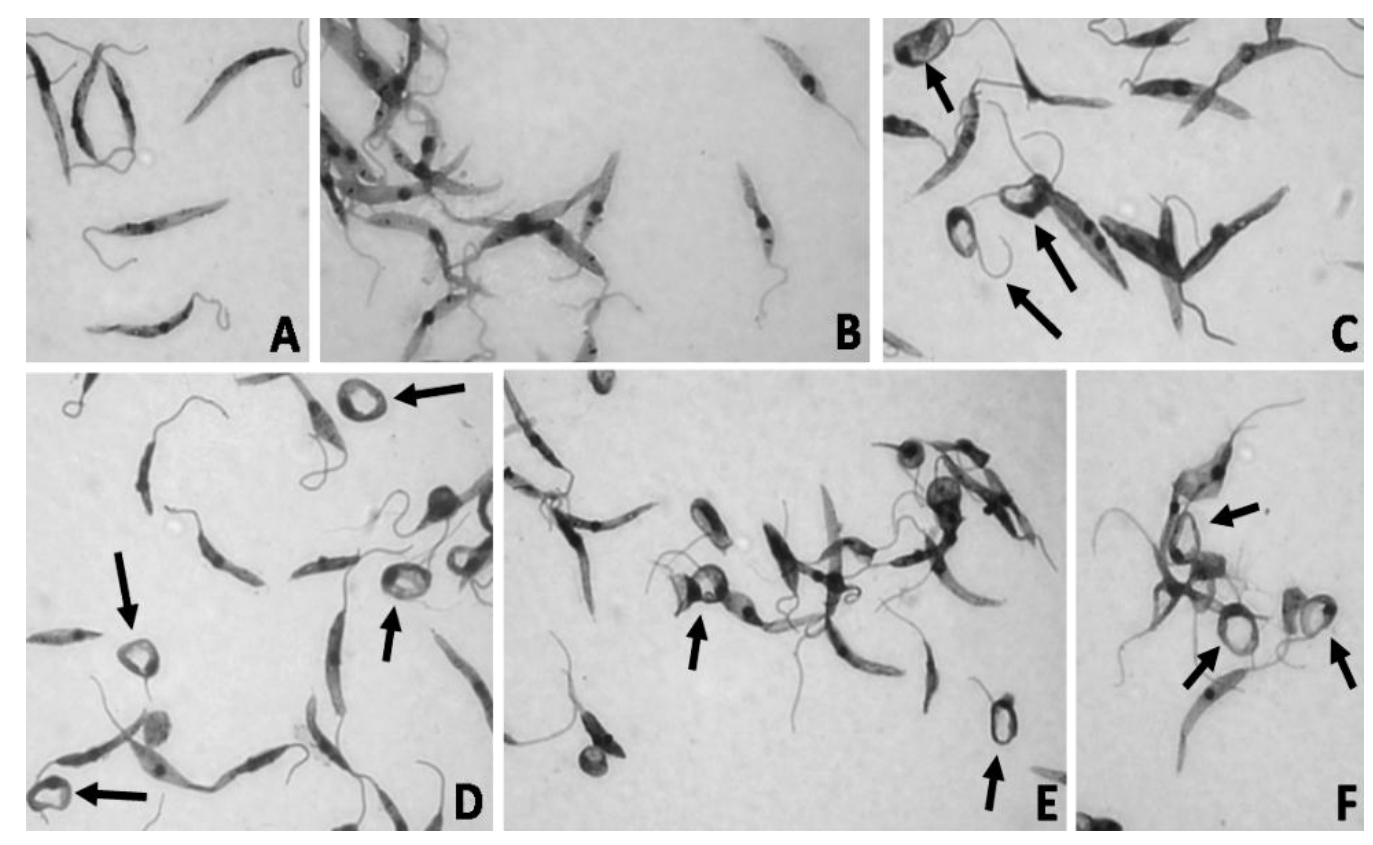

Figura 15. Alterações morfológicas de promastigotas de L. (L.) amazonensis observadas após incubação com tamoxifeno. Aproximadamente $5 \times 10^{6}$ promastigotas de fase logarítmica foram cultivados na ausência ou na presença de tamoxifeno em diferentes concentrações por 30 e 90 minutos a $25^{\circ} \mathrm{C}$. Após a incubação, as culturas foram lavadas com PBS $1 \mathrm{X}$ e alíquotas de $20 \mu \mathrm{L}$ de cada cultura foram aplicadas em lâminas. Após secos, os esfregaços foram fixados com metanol por 5 minutos, corados com o kit Instant Prov ${ }^{\circledR}$ e observadas em microscopia ótica. A e B: parasitas não tratados e cultivados por 30 e 90 minutos, respectivamente. Em C e D observamos promastigotas incubados por 30 minutos com tamoxifeno 10 e $20 \mu \mathrm{M}$, respectivamente. Nas imagens $\mathbf{E}$ e $\mathbf{F}$ temos parasitas tratados com tamoxifeno 10 e $20 \mu \mathrm{M}$, respectivamente, por 90 minutos. As setas apontam para formas celulares arredondadas que apresentam "espaço" citoplasmático aparentemente hialino. Estas formas não foram visualizadas nos grupos que não receberam tamoxifeno. As fotomicrografias foram obtidas de imagens aumentadas $1.000 \mathrm{X}$.

Prosseguimos nossas investigações analisando o aspecto ultraestrutural dos promastigotas tratados por microscopia eletrônica de transmissão. Esta técnica permitiu avaliarmos com precisão a organização estrutural de parasitas tratados com $20 \mu \mathrm{M}$ de tamoxifeno por $2 \mathrm{~h}$. Nesse período de tratamento, as células apresentavam-se ainda sem sinais evidentes de falência. Na Figura 16A é apresentada a fotomicrografia de um parasita controle com estruturas típicas como flagelo, cinetoplasto, bolso flagelar e acidocalcissomas bem preservadas. As fotomicrografias da sequência (Figura 16 B-E) revelam a ultraestrutura dos parasitas que receberam tamoxifeno. É possível notar a alteração da estrutura mitocondrial, com edema pronunciado e desorganização das cristas. Também nota-se uma intensa degeneração da organização citoplasmática com marcante vacuolização (Figura 16CE). O núcleo, como exemplificado na Figura 16C, também mostra sinais de lesão estrutural. 
Mesmo sabendo de uma possível interação tamoxifeno-membrana, não foi identificada alteração na estrutura da membrana plasmática do parasita, bem como sinais de descontinuidade ou ruptura da mesma. O DNA do cinetoplasto também se manteve inalterado nas imagens analisadas (Figura 16B).

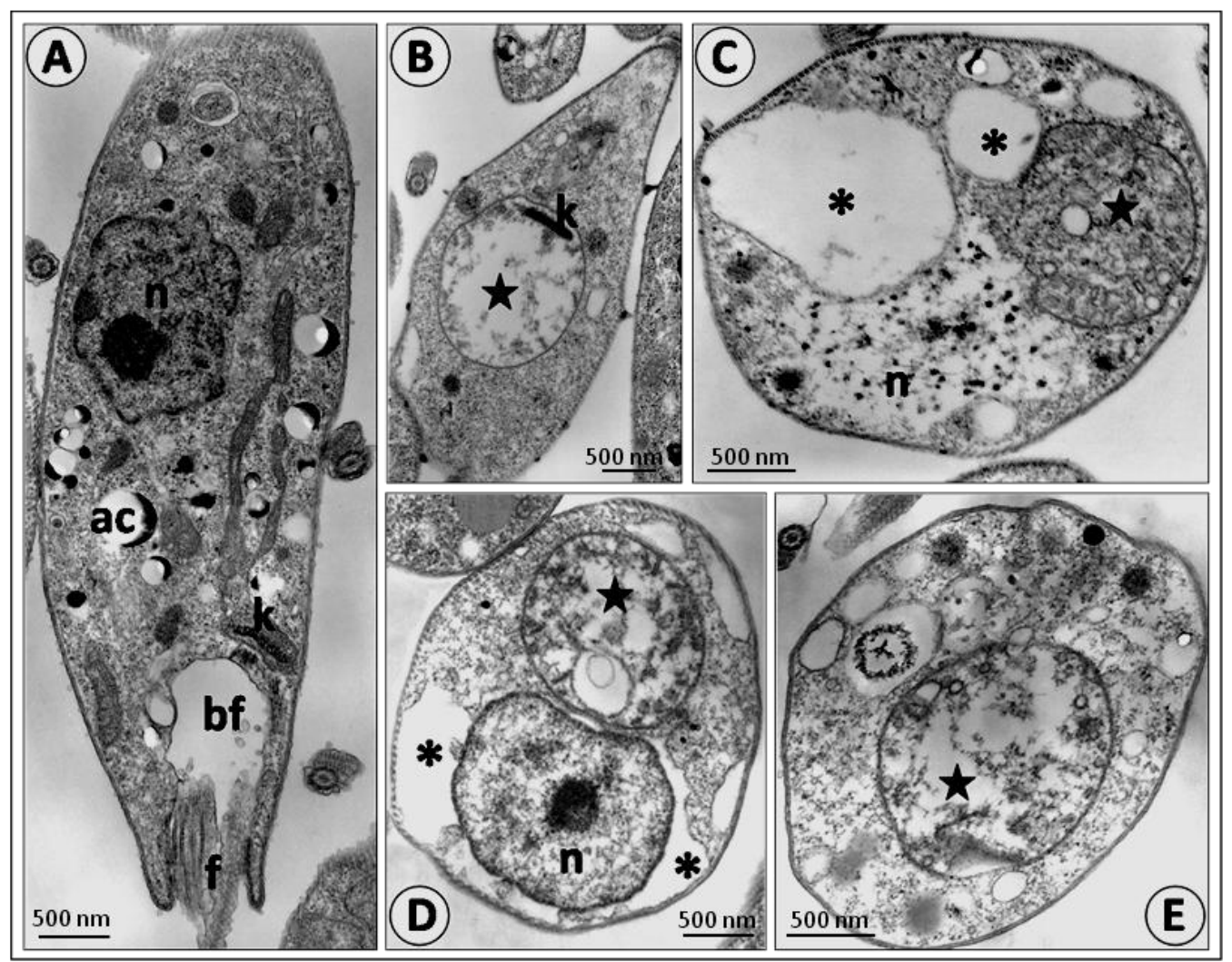

Figura 16. Microscopia eletrônica de transmissão de parasitas tratados com tamoxifeno. Promastigotas de fase logarítmica de L. (L.) amazonensis foram incubados em PBS-glicose $1 \mathrm{~g} / \mathrm{L}$ na ausência (A) ou na presença de $20 \mu \mathrm{M}$ de tamoxifeno por $2 \mathrm{~h}$ (B-E). Nas imagens de parasitas tratados podem ser visualizadas mitocôndrias com membrana ainda intacta, porém inchadas e com cristas mitocondriais destruídas (estrelas). Os asteriscos indicam vacúolos citoplasmáticos sem conteúdo elétron-denso. $\mathbf{n}$ : núcleo, ac: acidocalcissoma, k: cinetoplasto contendo kDNA, bf: bolso flagelar e f: flagelo.

Estudos de Bera e colaboradores demonstraram que peptídeos antimicrobianos são capazes de provocar efeitos semelhantes em promastigotas de L. (L.) donovani. Sinais como desorganização citoplasmática com presença de vacúolos também foram observados após incubação com os peptídeos indolicidina e 27RP, porém, com detecção de alterações na membrana plasmática como a presença de blebbings. No caso deste estudo, os autores atribuíram o mecanismo de ação à morte celular por autofagia (Bera et al., 2003).

\subsection{Interferência do tamoxifeno no metabolismo de esfingolipídios de Leishmania}




\subsubsection{Esfingolipídios em Leishmania spp.}

Os esfingolipídios são moléculas encontradas nos organismos eucariontes e procariontes, distribuídos majoritariamente em membranas, mas também associados a lipoproteínas. Nos últimos anos a literatura referente a este tema tem crescido expressivamente, principalmente no que diz respeito à descrição das funções destas moléculas. Atualmente assumem-se três funções biológicas principais para os esfingolipídios: estrutural, de reconhecimento e de sinalização celular (Varki, 1993; revisado em Merril Jr e Sandhoff, 2006). A estrutura característica destas moléculas é uma base esfingoide que apresenta uma cadeia alquil com número variado de carbonos (14 a 26), diferentes graus de saturação entre os carbonos 4 e 5, um grupo hidroxila na posição 4 ou 6 e duplas ligações variáveis e grupos metila inseridos ao longo da cadeia carbônica. Com base nessa diversidade estrutural, estima-se que existam mais de 60 diferentes tipos de bases esfingoides. A maior parte delas é $\mathrm{N}$-acilada com ácidos graxos de cadeia longa dando origem às ceramidas (Figura 17). Os ácidos graxos podem variar no comprimento da cadeia (14 a 30 átomos de carbono), grau de insaturação e presença ou ausência do radical hidroxila (revisado em Ogretmen e Hannun, 2004; Merril Jr e Sandhoff, 2006).

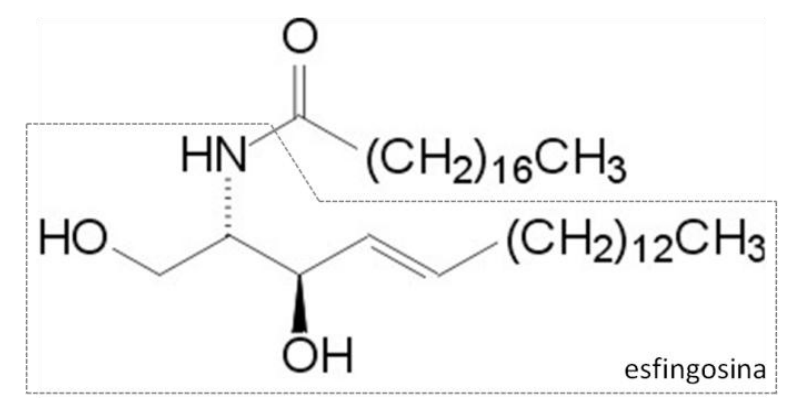

Figura 17. Estrutura química da ceramida ( $\mathbf{N}$-acilesfingosina). A estrutura de uma base esfingoide típica está destacada na caixa pontilhada.

A via de biossíntese de esfingolipídios gera moléculas altamente complexas incluindo fosfoesfingolipídios e glicoesfingolipídios neutros e acídicos, a partir de uma molécula central: 
a ceramida. Esta estrutura pode ser formada a partir da via de síntese de novo, iniciada com a condensação de L-serina e palmitoil-CoA, ou pela via de salvação, como pela hidrólise de esfingomielina e de cerebrosídeos ou a partir de bases esfingoides livres (revisado em Ogretmen e Hannun, 2004; Figura 18).

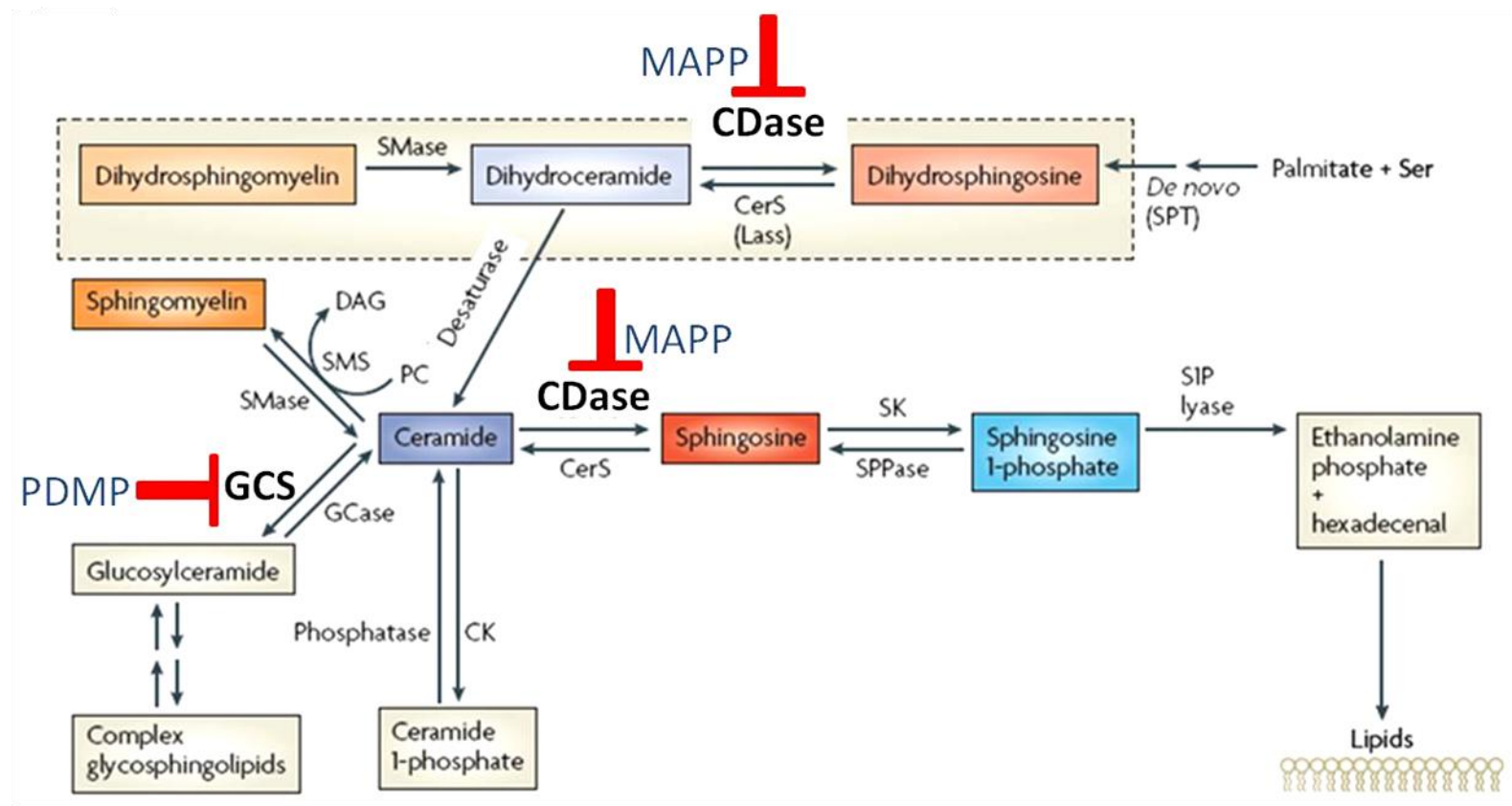

Figura 18. Biossíntese de esfingolipídios em mamíferos. Via de biossíntese de novo e de salvação de ceramida. Estão destacados em vermelho os sítios de inibição da atividade enzimática para os inibidores estudados neste trabalho: MAPP, um inibidor de ceramidase (CDase) e PDMP, inibidor da glucosilceramida sintase (GCS). Abreviaturas: Ser: serina, SPT: serina-palmitoil transferase, CerS: ceramida sintase, SMase: esfingomielinase, PC: fosfatidilcolina, SMS: esfingomielina sintase, DAG: diacilglicerol, GCase: glucosilceramidase, CK: ceramida quinase, SK: esfingosina quinase, SPPase: esfingosina 1-fosfato fosfatase, S1P: esfingosina 1-fosfato.

Fonte: Figura modificada de Hannun e Obeid, 2008.

Em Leishmania, os esfingolipídios estão abundantemente presentes em microdomínios de membrana conhecidos como rafts e correspondem a cerca de $10 \%$ da composição lipídica total de promastigotas de L. (L.) major (revisado em Suzuki et al., 2008; Zhang e Beverley, 2010). A vasta maioria dos esfingolipídios é composta por inositol-fosforilceramida (IPC) e ceramida. Kaneshiro e colaboradores demonstraram que promastigotas de L. (L.) donovani apresentam grandes quantidades de inositol-esfingolipídios (Kaneshiro et al., 1986). Em L. (L.) major, foi descrita uma estrutura aparentemente conservada para os esfingolipídios: base esfingoide esfingosina (d16:1) e cadeia acilada de 18C (18:0), o que sugere a incorporação 
preferencial de miristoil-CoA, ao invés de palmitoil-CoA, na biossíntese de ceramida (Hsu et al., 2007). Zhang e colaboradores estabeleceram uma linhagem de parasitas mutantes (spt2-, deficiente para o gene que codifica a subunidade 2 da enzima serina-palmitoiltransferase), que, apesar de viável, mostrou-se incapaz de diferenciar-se do estágio procíclico para o metacíclico. Este resultado também foi confirmado por Denny e colaboradores que verificaram que mutantes de L. (L.) major incapazes de biossintetizar esfingolipídios de maneira integral são viáveis, mas incapazes de completar a metaciclogênese. Além disso, estes parasitas acumularam quantidades anormais de glicoconjugados em estruturas vesiculares quando examinados por microscopia eletrônica (Zhang et al., 2003; Denny et al., 2004). Mais recentemente, Zhang e colaboradores demonstraram que ao adicionar etanolamina às culturas da linhagem spt2- há a recuperação do fenótipo destes mutantes, sugerindo que a etanolamina seja um dos principais produtos da via de biossíntese de esfingolipídios em Leishmania e precursor responsável pela integração desta via à biossíntese de glicerofosfolipídios nestes parasitas (Zhang et al., 2007; revisado em Zhang et al., 2010).

Além do estabelecimento destes mutantes, tanto a estrutura do IPC como a atividade de IPC sintases purificadas e recombinantes já foram descritas para Leishmania e outro tripanossomatídeo de importância médica, o T. cruzi (Zhang et al., 2003; Denny et al., 2004; Figueiredo et al., 2005; Denny et al., 2006; Hsu et al., 2007; Mina et al., 2010). É consenso entre todos os grupos que investigam a biossíntese dos esfingolipídios que o IPC é uma molécula-alvo no que diz respeito ao desenvolvimento de drogas antiLeishmania/Trypanosoma e antifúngicas, já que sua biossíntese é exclusiva de tripanossomatídeos e fungos (Hanada et al., 2003). O equivalente em mamíferos é a esfingomielina, molécula formada pela adição de fosfocolina à ceramida por uma esfingomielina sintase (revisado em Merril Jr e Sandhoff, 2006). Tanto o IPC quanto outros produtos gerados por esta rota metabólica parecem imprescindíveis para diversos processos celulares como diferenciação e reconhecimento, a exemplo dos agrupamentos polares dos fosfoesfingolipídios capazes de desempenhar funções importantes como o ancoramento de proteínas à membrana celular (revisado em Lester e Dickson, 1993).

Apesar de determinadas etapas da via de biossíntese de esfingolipídios já estarem bem descritas para Leishmania, ainda não se demonstrou a essencialidade dos esfingolipídios 
principalmente para formas amastigotas, já que estes parasitas são capazes de sobreviver na ausência de glicoesfingolipídios, por exemplo. Contudo Winter e colaboradores sugeriram que amastigotas de Leishmania compensam a falta da síntese desses lipídios graças ao sequestro de glicoesfingolipídios do hospedeiro in vivo (revisado em Denny e Smith, 2004). Mais recentemente, um estudo demonstrou que L. (L.) major exibe potente atividade de esfingomielinase e que, possivelmente, esse efeito está relacionado à degradação de esfingomielina da célula hospedeira. Além disso, esta inibição mostrou-se importante no controle da proliferação do parasita e pareceu interferir na manifestação da doença em modelo murino (Zhang et al., 2009).

Embora seja conhecido que tamoxifeno possa interferir no metabolismo de lipídios em células intactas e tecidos, um impacto direto do fármaco nas enzimas do metabolismo lipídico ainda não havia sido claramente evidenciado. Com base nestas considerações, Cabot e colaboradores investigaram se tamoxifeno seria capaz de atuar na inibição de determinada(s) enzima(s) do metabolismo de ceramidas em células neoplásicas resistentes a múltiplas drogas. Esses pesquisadores constataram que tamoxifeno inibe a atividade da glicosilceramida (GC) sintase, a enzima catalisadora da glicosilação de ceramida (Cabot et al., 1996). Esta reação de glicosilação é a primeira etapa da via de biossíntese de glicoesfingolipídios, que se dá a partir da transferência de glicose de UDP-glicose para a ceramida, resultando em GC e UDP (Basu et al., 1968).

Com base nestes dados, optamos por avaliar quais seriam os efeitos de tamoxifeno na biossíntese de esfingolipídios de L. (L.) amazonensis. Inicialmente, decidimos averiguar se promastigotas desta espécie seriam capazes de sintetizar GC. Diversos experimentos foram conduzidos em parceria com o laboratório dos Profs. Drs. Anita Straus e Helio Takahashi (Universidade Federal de São Paulo) a partir da análise total de extratos lipídicos de parasitas tratados ou não com tamoxifeno. Essa premissa parecia pertinente já que Straus e colaboradores haviam relatado a presença de glicoesfingolipídios em amastigotas derivados de lesão de camundongos (Straus et al., 1997). No entanto, nossos experimentos utilizando extratos lipídicos totais separados em HPTLC não revelaram alteração nos níveis de cerebrosídeos, globosídeos, IPC e fosfolipídios (fosfoetanolamina, fosfoinositol e fosfocolina) após incubação de promastigotas por $24 \mathrm{~h}$ com a droga (dados não apresentados). Nenhum 
sinal para uma banda com $\mathrm{R} f$ correspondente ao padrão de GC foi detectado em diversas tentativas. Lançamos mão de uma segunda alternativa que foi a purificação de nossas amostras para extração de GC por Partição de Folch, conforme descrito em Barreto-Bergter et al., 2004. Ainda assim, não obtivemos sucesso na detecção de uma possível GC em promastigotas de L. (L.) amazonensis. A utilização de extratos lipídicos totais de parasitas não marcados ("frios") não permitiu uma clara identificação de alterações no perfil lipídico após tratamento com tamoxifeno. Optamos, assim, pelo emprego de uma técnica que fosse mais sensível e que pudesse fornecer um sinal amplificado do pool de lipídios biosintetizados pelo parasita, utilizando um precursor da via dos esfingolipídios marcado com o fluoróforo NBD (nitrobenzo-2-oxa-1,3-diazol).

\subsubsection{Incorporação de $C_{6}$-NBD-ceramida por promastigotas de L. (L.) amazonensis}

Buscando então uma estratégia metodológica de maior sensibilidade, optamos por avaliar a biossíntese de esfingolipídios oferecendo um precursor metabólico da via $\left(\mathrm{C}_{6}-\mathrm{NBD}\right.$ ceramida, Figura 19A) aos parasitas de cultura. Lipídios contendo grupos fluorescentes (por ex. NBD, BODIPY e pireno) vem sendo utilizados no estudo de metabolismo e transporte celulares. O fluoróforo NBD é uma molécula amplamente empregada em experimentos na pesquisa de lipídios graças à propriedade de ligar-se facilmente ao grupo acil lipídico. Os picos de emissão/excitação de NBD estão próximos a 470/530 nm (revisado em Rasmussen e Hermetter, 2008). O primeiro passo, portanto, foi confirmar se promastigotas de L. (L.) amazonensis seriam capazes de incorporar $\mathrm{C}_{6}$-NBD-ceramida diretamente do meio de cultura. Para isso, incubamos $2 \times 10^{8}$ promastigotas com $5 \mu \mathrm{M}$ de $\mathrm{C}_{6}$-NBD-ceramida em solução balanceada de Hanks por 15 min a $4{ }^{\circ} \mathrm{C}$ para análise por microscopia de fluorescência (Figura 19B, painel superior). A marcação verde revela a incorporação do precursor localizada próximo ao centro do corpo celular e associada à marcação de DNA pelo DAPI (azul), sugerindo marcação do aparelho de Golgi. Lipsky e Pagano já haviam descrito NBD-ceramida como um marcador dessa organela em células eucarióticas (Lipsky e Pagano, 1985). 
Paralelamente, parasitas mantidos a temperatura ambiente por 20 min após a incubação a 4 ${ }^{\circ} \mathrm{C}$ apresentaram fluorescência dispersa ao longo do corpo celular, um efeito esperado já que esta molécula pode ter sido assimilada na estrutura de diversos esfingolipídios mais complexos, o que permitiria a marcação fluorescente do citoplasma (Figura 19B, painel inferior).

A

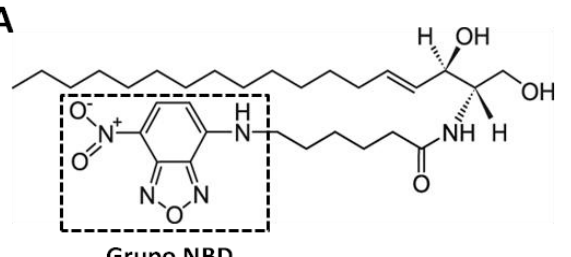

Grupo NBD

B
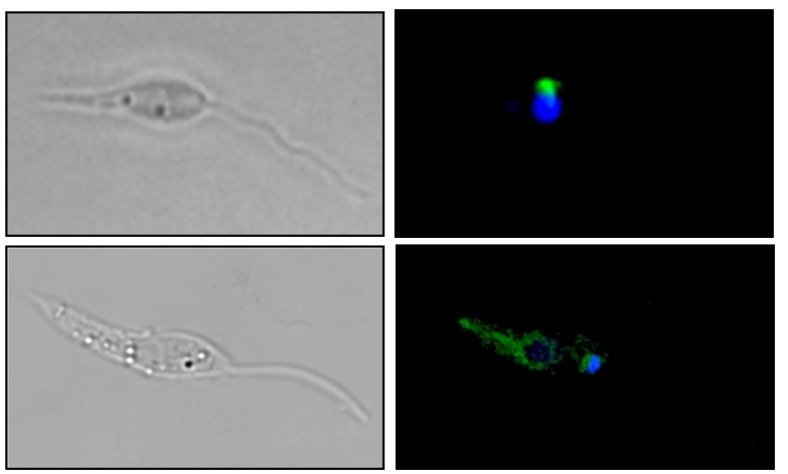

Figura 19. Incorporação de $\mathrm{C}_{6}$-NBD-ceramida por promastigotas de L. (L.) amazonensis. A: Estrutura química do precursor $\mathrm{C}_{6}$-NBD-ceramida utilizado em nossos experimentos, com destaque para o grupo NBD (fluoróforo). B, painel superior: Imagem de promastigota incubado por $5 \mathrm{~min}$ a $4^{\circ} \mathrm{C}$ com o precursor e observado em contraste de fase (esquerda) e fluorescência (direita). B, painel inferior: promastigota incubado conforme descrito anteriormente e mantido por $15 \mathrm{~min}$ a temperatura ambiente. DAPI 10 $\mu \mathrm{g} / \mathrm{mL}$ foi adicionado no momento da análise. Aumento de $1.000 \mathrm{X}$.

\subsubsection{Atividade leishmanicida dos inibidores Fumonisina B1, MAPP, PDMP e PPMP}

Sabendo que promastigotas de Leishmania são, portanto, capazes de incorporar NBDceramida, decidimos avaliar o padrão de esfingolipídios sintetizados a partir deste precursor em condições normais de cultura e após incubação com tamoxifeno. Previamente, porém, decidimos avaliar o efeito leishmanicida de inibidores de diferentes enzimas do metabolismo de esfingolipídios de células de mamíferos já descritos na literatura, para utilização dos mesmos como controles em nossos experimentos de marcação metabólica. 
Os compostos PDMP (D-treo 1-fenil-2-decanoilamino-3-morfolino-1-propanol) e PPMP (D,L-treo-1-fenil-2-palmitoilamino-3-morfolino-1-propanol) são reconhecidamente descritos como inibidores da atividade da GC sintase (Radin et al., 1993), resultando no acúmulo do conteúdo de ceramida (Abe et al., 1992). Outros inibidores análogos de ceramida, como o MAPP ((1S,2R)-D-eritro-2-(N-miristoilamino)-1-fenil-1-propanol), são capazes de inibir a atividade da ceramidase ácida e neutra resultando no aumento substancial dos níveis de ceramida intracelular (Bielawska et al., 1992; Alphonse et al., 2004). A Fumonisina B1 é um inibidor da enzima ceramida sintase capaz não só de bloquear a formação de esfingolipídios complexos, mas também de provocar o acúmulo de esfinganina na célula (Wang et al., 1991; Schmelz et al., 1998).

Considerando o efeito modulador do metabolismo de ceramidas desses inibidores, decidimos avaliar o efeito dos mesmos em culturas de promastigotas de L. (L.) amazonensis de modo a estabelecer as concentrações ideais a serem utilizadas em ensaios posteriores. $\mathrm{Na}$ Tabela 3 são apresentados os valores de $I_{50}, I_{90}$ e $C C_{50}$ para cada um dos inibidores para culturas de parasitas e células CHO-K1 e HEp-2, respectivamente. A viabilidade celular foi avaliada pelo método colorimétrico de MTT.

Tabela 3 - Atividade leishmanicida e citotóxica de inibidores específicos da via de síntese de esfingolipídios em mamíferos.

\begin{tabular}{|l|c|c|c|c|}
\hline \multicolumn{1}{|c|}{ Inhibidor $^{\text {a }}$} & $\begin{array}{c}\text { L. (L.) amazonensis } \\
\mathrm{IC}_{50} \pm \mathrm{DP}(\mu \mathrm{M})^{\mathbf{b}}\end{array}$ & $\begin{array}{c}\text { L. (L.) amazonensis } \\
\mathrm{IC}_{90}(\mu \mathrm{M})\end{array}$ & $\begin{array}{c}\text { Célula CHO-K1 } \\
\mathrm{CC}_{50} \pm \mathrm{DP}(\boldsymbol{\mu} \mathrm{M})\end{array}$ & $\begin{array}{c}\text { Célula HEp-2 } \\
\mathbf{C C}_{50} \pm \mathrm{DP}(\boldsymbol{\mu} \mathrm{M})\end{array}$ \\
\hline Fumonisina B1 & $>200,0$ & $\mathrm{nd}$ & $>200,0$ & $>200,0$ \\
\hline MAPP & $112,6 \pm 8,0$ & 689,7 & $>150,0$ & $>150,0$ \\
\hline PDMP & $62,5 \pm 5,6$ & 89,1 & $96,6 \pm 1,5$ & $118,0 \pm 4,4$ \\
\hline PPMP & $26,5 \pm 1,5$ & 68,4 & $>150,0$ & $66,5 \pm 5,0$ \\
\hline
\end{tabular}

a Incubação por 24 h.

${ }^{\mathrm{b}}$ DP; desvio-padrão da média de dois experimentos realizados em triplicatas. nd; não detrminado.

Observamos que a Fumonisina B1, nas concentrações empregadas, não apresentou efeito leishmanicida, resultado semelhante àquele verificado por Figueiredo que havia 
descrito a fraca atividade deste inibidor para epimastigotas de T. cruzi (Figueiredo, 2008). As concentrações de MAPP, PDMP e PPMP necessárias de para inibir o crescimento dos parasitas mantiveram-se na faixa de micromolar, a mesma descrita para os efeitos de inibição de GC sintase e ceramidase em diversos modelos celulares, por exemplo, em linhagem leucêmica humana (HL-60) e de fibroblastos humanos de pele, respectivamente (Bielawska et al., 1996; Makino et al., 2006). Além disso, alguns estudos demonstraram que etapas do ciclo celular do parasita unicelular Giardia lamblia, como a replicação de trofozoítas e a formação de cistos, são processos radicalmente alterados na presença de PPMP in vitro quando utilizados em concentrações entre 1 a $20 \mu \mathrm{M}$ (Sonda et al., 2008) ou 30 a $120 \mu \mathrm{M}$ (Hernandez et al., 2008). Kóvacs e colaboradores demonstraram que doses de 20, 40 e até $80 \mu \mathrm{M}$ de PPMP e PDMP influenciam a síntese de glicoesfingolpídios com aumento dos níveis de ceramida em Tetrahymena pyriformis, um ciliado de vida livre (Kóvacs et al., 2000). Ainda em relação à atividade destes inibidores específicos contra protozoários, já foi verificado que o tratamento de culturas de Plasmodium falciparum com PPMP resultou em potente inibição da maturação do estágio intraeritrocítico do parasita in vitro (Lauer et al., 2001).

Como parte do estudo dos efeitos destes inibidores em promastigotas de Leishmania, também foi avaliada a morfologia dos parasitas incubados com MAPP e PDMP em diferentes concentrações por 24 h, por microscopia ótica e eletrônica de transmissão. Quando comparados às células do grupo controle, parte dos promastigotas tratados com MAPP apresentou alterações morfológicas após tratamento com doses superiores a $225 \mu \mathrm{M}$, como aumento do volume celular e o aparecimento de espaços citoplasmáticos (Figura 20C, setas finas). Estas modificações foram mais frequentes no caso de parasitas tratados com $450 \mu \mathrm{M}$ de MAPP (Figura 20D, setas finas). No caso dos parasitas tratados com PDMP, alterações acentuadas na morfologia foram verificadas a partir da dose de $50 \mu \mathrm{M}$. Conforme aumentadas as concentrações do inibidor, maior foi a frequência de parasitas com tamanho reduzido, piriformes ou com formato arredondado (Figura 20F-H, setas grossas). No caso de parasitas incubados com $300 \mu \mathrm{M}$ de PDMP, foram detectadas formas celulares arredondadas apresentando flagelos bastante alongados (Figura 20H, " $f$ "). Observando as concentrações inibitórias descritas na Tabela 3 (IC 90 para PDMP próxima a $90 \mu \mathrm{M})$, podemos deduzir que a 
maioria das células apresentadas na Figura G e H já não estavam mais viáveis após o período de incubação com PDMP.

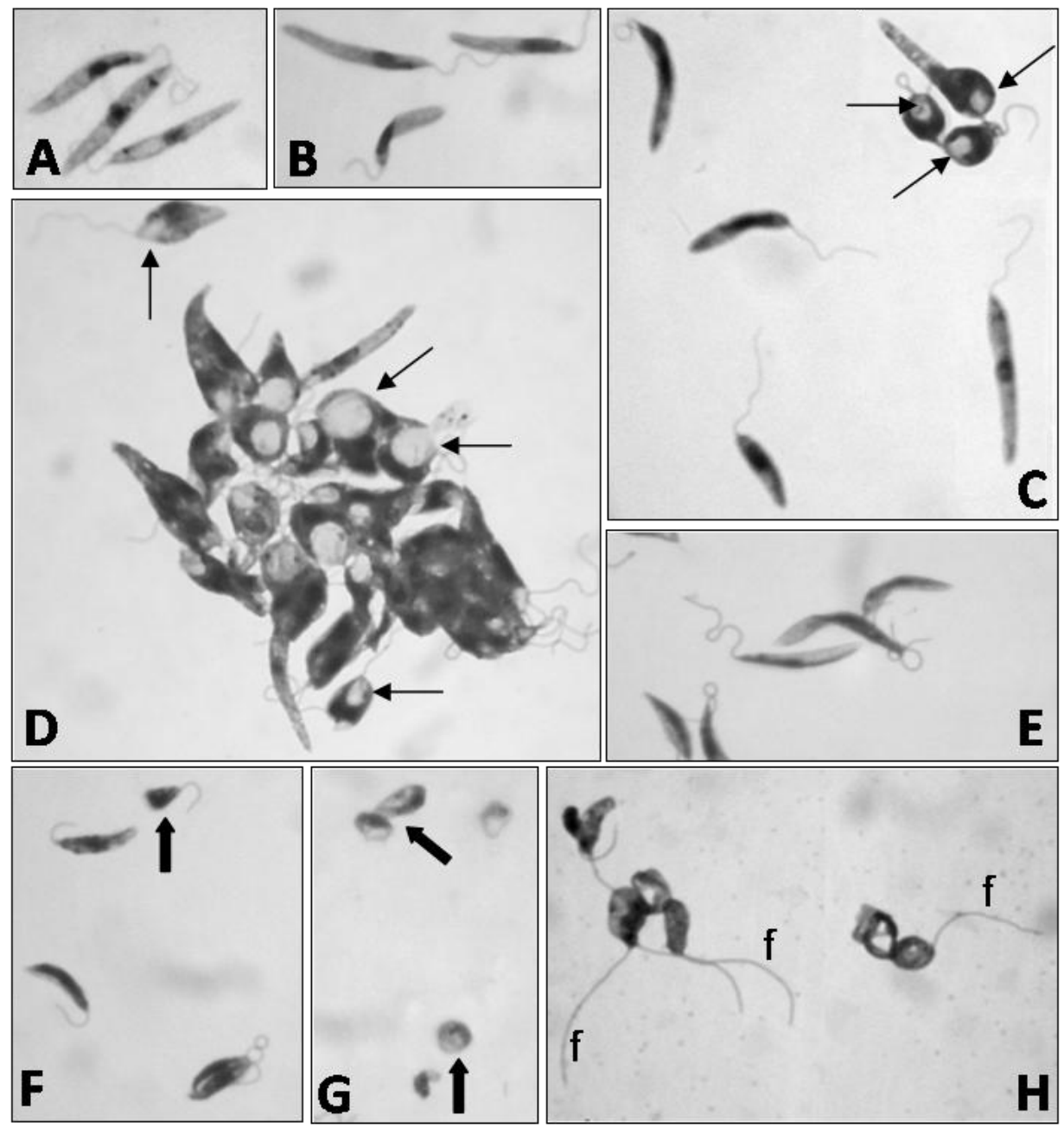

Figura 20. Microscopia ótica de promastigotas tratados com inibidores específicos de enzimas da via de biossíntese de esfingolipídios. Culturas de promastigotas de $L$. (L.) amazonensis foram mantidas na ausência (A) ou na presença de 100, 225 e $450 \mu \mathrm{M}$ de MAPP (B-D) ou 10, 50, 100 e $300 \mu \mathrm{M}$ de PDMP (EH) por $24 \mathrm{~h}$. A seguir alíquotas foram utilizadas para o preparo de lâminas posteriormente fixadas e coradas com o kit Instant Prov ${ }^{\circledR}$. As setas finas apontam para formas arredondadas contendo grandes espaços citoplasmáticos. As setas grossas indicam células de formato alterado (redondo e piriforme). "f"; flagelos alongados. Aumento de 1.000X.

A seguir, avaliamos os efeitos destes inibidores na ultraestrutura dos parasitas. É importante ressaltar que neste caso, o tempo de incubação foi reduzido com o intuito de registrarmos eventos iniciais resultantes da interação destes compostos com os parasitas. 
Promastigotas foram incubados com $200 \mu \mathrm{M}$ de MAPP (Figura 21B-E) ou $100 \mu \mathrm{M}$ de PDMP (Figura 21F,G) por $1 \mathrm{~h}$. Promastigotas tratados com MAPP apresentaram áreas de aparente descolamento da membrana plasmática (Figura 21B,D). Além disso, observamos regiões de vacuolização citoplasmática, conforme mostrado na Figura 21E. No caso desta imagem ainda pode se observar a alteração drástica no volume e estrutura mitocondrial. Quando observamos os parasitas tratados tanto com MAPP como com PDMP, identificamos estruturas multilamelares peculiares presentes no citoplasma de diversas células, muito semelhantes a vacúolos autofágicos (Figura 21B,C,F e G). Tais achados corroboram dados de Makino e colaboradores que apresentaram evidências ultraestruturais de que fibroblastos humanos de pele incubados com $10 \mu \mathrm{M}$ de PDMP por $48 \mathrm{~h}$ acumularam estruturas multilamelares no citoplasma (Makino et al., 2006). Apesar de detectarmos os achados ultraestruturais atípicos descritos acima, outras estruturas como núcleo, cinetoplasto contendo kDNA, mitocôndria, acidocalcissoma e bolso flagelar apresentavam-se aparentemente conservadas. Nossos resultados configuram o primeiro relato da atividade leishmanicida de inibidores clássicos da via de ceramidas, bem como a análise ultraestrutural de promastigotas de L. (L.) amazonensis quando incubados com os mesmos.

A comparação entre as alterações morfológicas induzidas por MAPP e PDMP (Figuras 20 e 21) com as observadas após tratamento com tamoxifeno (Figuras 15 e 16) revelou uma alteração comum à induzida por MAPP, ou seja, células arredondadas contendo grandes vacúolos no citoplasma e com aparente degeneração da matriz mitocondrial. 

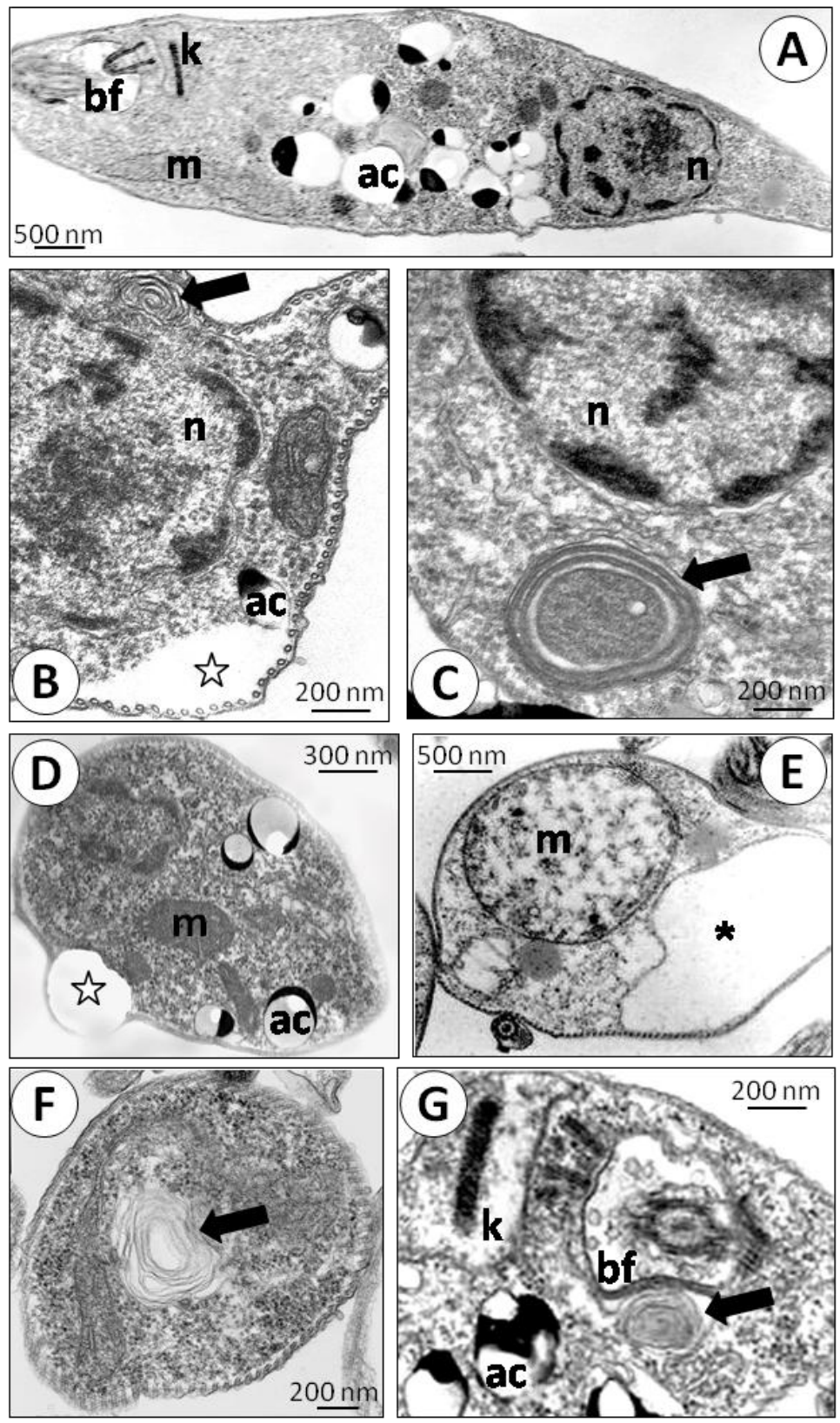

Figura 21. Microscopia eletrônica de transmissão de promastigotas de L. (L.) amazonensis tratados com inibidores específicos de enzimas da via de biossíntese de esfingolipídios. Parasitas foram cultivados na ausência (A) ou na presença de $200 \mu \mathrm{M}$ de MAPP (B-E) ou $100 \mu \mathrm{M}$ de PDMP (F,G) por $1 \mathrm{~h}$. Em B e D podem ser visualizadas áreas de despregamento da membrana plasmática (estrelas) e em E está destacada uma extensa área vacuolizada no corpo celular. Neste exemplo a célula apresenta ainda aumento do volume mitocondrial. As setas pretas apontam para estruturas multilamelares presentes para ambas os inibidores. "bf": bolso flagelar, "k": DNA mitocondrial encerrado no cinetoplasto, " $\mathrm{m}$ ": mitocôndria, "ac": acidocalcissoma, "n": núcleo. 


\subsubsection{Incorporação de $C_{6}-N B D$-ceramida em parasitas tratados com MAPP, PDMP e tamoxifeno}

Ao fornecermos $\mathrm{C}_{6}$-NBD-ceramida a parasitas previamente tratados com os inibidores de interesse, incluindo o tamoxifeno, poderíamos observar o perfil de incorporação do precursor em produtos mais complexos da via de esfingolipídios. Para isso, adotamos o protocolo de marcação descrito por Boath e colaboradores para análise de esfingolipídios de células COS-1 (fibroblastos renais de macaco verde) (Boath et al., 2008).

Assim, para análise do padrão global de incorporação de C $_{6}$-NBD-ceramida, aproximadamente $4 \times 10^{8}$ promastigotas de L. (L.) amazonensis de fase logarítmica foram incubados por $1 \mathrm{~h}$ e $30 \mathrm{~min}$ com $10 \mu \mathrm{M}$ de tamoxifeno, $100 \mu \mathrm{M}$ de PDMP ou $200 \mu \mathrm{M}$ de MAPP. Após este período, os parasitas foram incubados com $10 \mu \mathrm{M}$ de $\mathrm{C}_{6}$-NBD-ceramida por mais 2 h e 30 min. O grupo controle não tratado recebeu apenas o precursor NBD-ceramida. Os extratos lipídicos obtidos após extração com clorofórmio:metanol:solução de Hanks/EDTA 10 mM (1:1:0,75; v:v:v) foram submetidos à HPTLC, como mostrado na Figura 22. Como esperado, o padrão de marcação de parasitas tratados com PDMP e MAPP mostrou-se alterado em relação às culturas não tratadas. Observamos maior abundância da banda de $\mathrm{R} f$ idêntico ao do padrão de NBD-ceramida em células tratadas com MAPP e PDMP (124 e 80\% de incremento em relação ao controle, respectivamente). No caso de parasitas que receberam tamoxifeno, não foi detectada alteração na intensidade desta banda (Figura 22), mas houve alteração no padrão global de marcação em relação ao controle não tratado. Podemos afirmar que o extrato lipídico de parasitas tratados com tamoxifeno, nas condições utilizadas, não apresenta o mesmo perfil daqueles extratos resultantes de tratamento com PDMP e MAPP, sugerindo que seu efeito não esteja relacionado à inibição da atividade de enzimas como GC sintase e ceramidase. Também podemos observar que o tamoxifeno, assim como os inibidores específicos PDMP e MAPP, foi capaz de interferir na incorporação da ceramida em outras moléculas desta via metabólica em parasitas tratados por um período de $4 \mathrm{~h}$. No entanto, as bandas que mostraram alteração de intensidade em parasitas tratados 
com tamoxifeno quando comparadas ao controle não puderam ser identificadas através de suas migrações relativas nesse sistema e com os padrões utilizados nesse experimento.

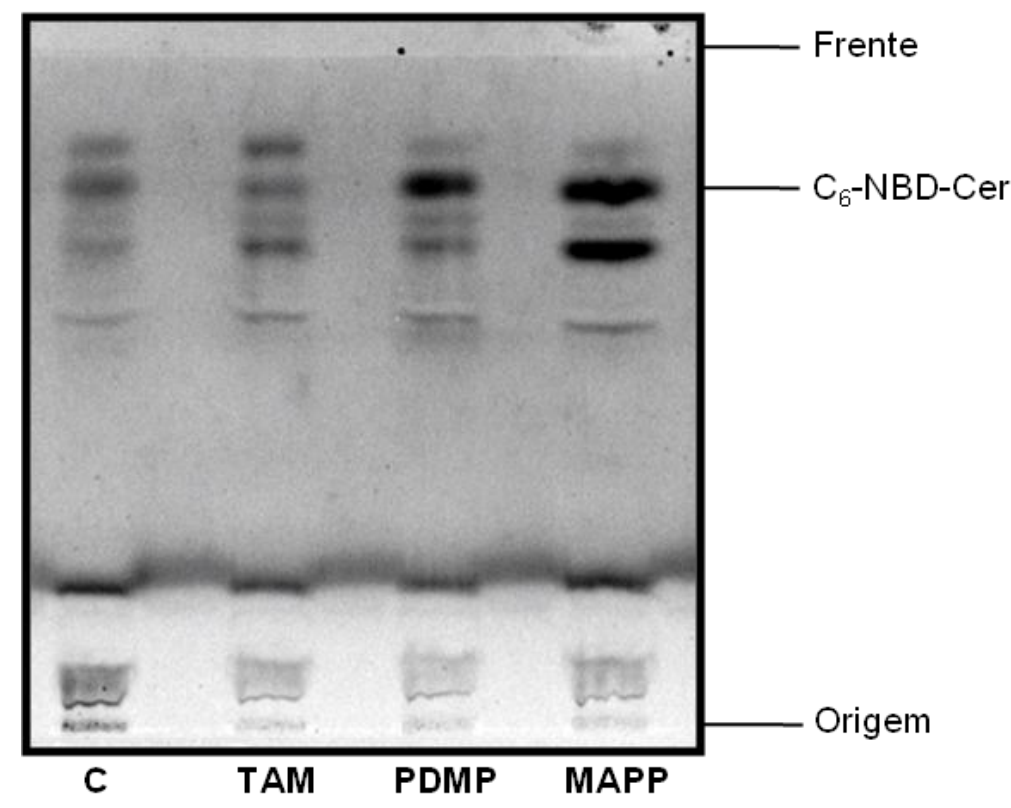

Figura 22. HPTLC do extrato lipídico de promastigotas de L. (L.) amazonensis após incorporação com $\mathrm{C}_{6}$-NBDceramida. $4 \times 10^{8}$ parasitas foram submetidos ao tratamento com $10 \mu \mathrm{M}$ de tamoxifeno (TAM), 100 $\mu \mathrm{M}$ de PDMP ou $200 \mu \mathrm{M}$ de MAPP por $1 \mathrm{~h}$ e $30 \mathrm{~min}$. Após este período foi acrescido $10 \mu \mathrm{M}$ de $\mathrm{C}_{6}$-NBDceramida por mais $2 \mathrm{~h}$ e $30 \mathrm{~min}$. O grupo controle (C) recebeu apenas o precursor NBD-ceramida. Ao final do período de incubação, foram obtidos extratos lipídicos após extração com clorofórmio:metanol:solução de Hanks/EDTA 10 mM (1:1:0,75; v:v:v). O sistema de solventes utilizado na corrida foi butanol:ácido acético:água (3:1:1; v:v:v). As bandas foram visualizadas em leitor de fluorescência (STORM 840). " $\mathrm{C}_{6}$-NBD-Cer"; $\mathrm{C}_{6}$-NBD-ceramida.

O incremento no conteúdo de ceramida endógena em parasitas tratados com MAPP e PDMP foi também avaliado após análise de promastigotas fixados com paraformaldeído marcados com o anticorpo monoclonal anti-ceramida tanto qualitativamente (por imunofluorescência indireta) como quantitativamente (por citometria de fluxo) (Figura 23). A observação por microscopia sugeriu uma maior intensidade de marcação nos parasitas tratados com MAPP quando comparados ao controle. Não se observou alteração na marcação em parasitas tratados com PDMP. Esses dados foram confirmados por citometria de fluxo, observando-se um incremento de cerca de $20 \%$ na marcação da população tratada com 
MAPP, em relação ao grupo controle. Novamente, para parasitas tratados com PDMP, não foi verificado aumento significativo da população Alexa-Fluor647-positiva quando comparado ao grupo controle (Figura 23B). Assim, a utilização do anticorpo anti-ceramida permitiu confirmar a observação derivada da marcação metabólica em parasitas tratados com MAPP. O mesmo não foi verificado em células tratadas com PDMP, em que a alteração foi observada apenas nos experimentos de incorporação de $\mathrm{C}_{6}$-NBD-ceramida. Esse fato pode ser atribuído à menor sensibilidade da técnica utilizando o anticorpo que visa avaliar a abundância global de ceramida da célula, submetida a um rígido controle metabólico.

Os experimentos descritos nesta etapa foram conduzidos durante o período de estágio de "Doutorado-sanduíche" realizado no laboratório da Dra. Norma Andrews, Universidade de Maryland, Estados Unidos.
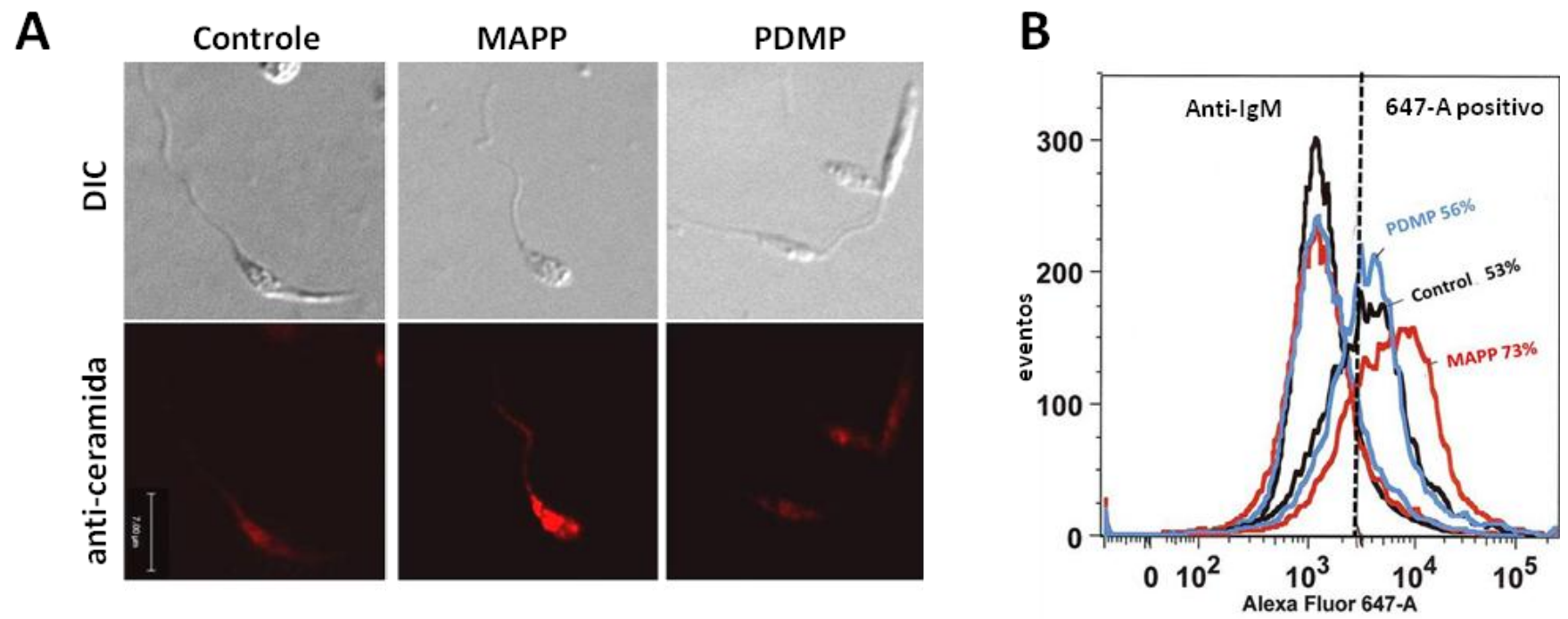

Figura 23. Níveis de ceramida endógena em parasitas tratados com MAPP e PDMP. Promastigotas de fase logarítmica de L. (L.) amazonensis foram fixados com paraformaldeído e incubados com o anticorpo monoclonal anti-ceramida (1:10) para ensaios de imunofluorescência indireta e visualização de promastigotas por fluorescência, que revelaram intenso sinal de para parasitas tratados com MAPP (A). B: quantificação por citometria de fluxo de população Alexa-Fluor positiva (anti-ceramidapositiva). As curvas à esquerda representam a detecção para culturas que receberam apenas o anticorpo secundário Anti-IgM. As curvas à direita indicam o tratamento utilizado e a porcentagem da população de parasitas Alexa-Fluor-positiva. Barra= $7 \mu \mathrm{m}$. 


\subsubsection{Modulação da biossíntese de esfingolipídios de L. (L.) amazonensis por tamoxifeno}

A obtenção de um maior número de moléculas padrão permitiu que prosseguíssemos nas análises de extratos de promastigotas marcados com o precursor $C_{6}-\mathrm{NBD}$-ceramida utilizando outro sistema de solventes em nossos ensaios por HPTLC, já que a metodologia descrita acima não permite uma separação ideal entre as bandas referentes à GC e ceramida. Decidimos, portanto, adotar o sistema de solventes utilizado por Ichikawa e colaboradores que avaliaram o perfil glicolipídico da linhagem murina mutante B16. Esse sistema permite uma separação ampla de lipídeos neutros e carregados. A separação por TLC neste caso foi realizada incubando-se a placa de sílica em cuba de vidro contendo a mistura clorofórmio:metanol:água (60:35:8, v:v:v) até que a mistura de solventes percorresse os $20 \%$ da distância total da placa a partir do local de aplicação das amostras. A seguir, a placa foi retirada e transferida a outra cuba contendo clorofórmio:metanol:ácido acético (90:2:8, v:v:v) onde a cromatografia foi finalizada (Ichikawa et al., 1994).

Em paralelo, decidimos avaliar também o padrão de marcação de amastigotas purificados de lesão, utilizando o precursor $\mathrm{C}_{6}$-NBD-ceramida, na ausência e na presença dos inibidores mencionados.

Culturas com inóculo de $4 \times 10^{8}$ promastigotas ou $1 \times 10^{7}$ amastigotas foram incubadas com $10 \mu \mathrm{M}$ de tamoxifeno, $100 \mu \mathrm{M}$ de PDMP ou $200 \mu \mathrm{M}$ de MAPP por $1 \mathrm{~h}$ e $30 \mathrm{~min}$. Em seguida foi adicionado de $10 \mu \mathrm{M}$ de $\mathrm{C}_{6}-\mathrm{NBD}$-ceramida por mais $2 \mathrm{~h}$ e $30 \mathrm{~min}$. Ao final do período de incubação, foram obtidos extratos lipídicos para separação por HPTLC com o sistema descrito anteriormente (Figura 24).

O padrão de marcação de esfingolipídios de promastigotas e amastigotas após incorporação de $\mathrm{C}_{6}$-NBD-ceramida mostrou-se bastante conservado. Diferenças foram observadas apenas na intensidade relativa de bandas com baixo $\mathrm{Rf}$ (denominadas $\mathrm{C}$ e $\mathrm{D}$ na Figura 24) quando comparados extratos dos dois estágios. As alterações decorrentes do tratamento com os inibidores PDMP e MAPP, assim como com tamoxifeno também foram semelhantes quando comparados os extratos obtidos a partir de promastigotas e amastigotas. 
Os extratos de promastigotas e amastigotas tratados com tamoxifeno (T) apresentaram aumento de 4,8 e 3,3 vezes, respectivamente, de intensidade da banda $A$ em relação ao grupo controle (C). Já para a banda $B$, foi verificado um aumento de 3,2 vezes para promastigotas tratados. Por outro lado, as bandas C e D apresentaram intensidade drasticamente reduzida nos parasitas tratados com tamoxifeno. O perfil de incorporação para tratamento com MAPP (M) para os dois estágios do parasita foi semelhante ao observado para tamoxifeno $(\mathbf{T})$, exceto pelo fato de a intensidade da banda B não ter sido alterada após a incubação com o inibidor de ceramidase. A incubação com PDMP (P) levou a um perfil de incorporação de NBD-ceramida praticamente idêntico àquele verificado para parasitas não tratados $(\mathbf{C})$, exceto por uma discreta redução na intensidade das bandas C e D de amastigotas tratados com o inibidor (Figura 24). Diferentemente do observado para o sistema de Boath e colaboradores (item 4.3.6.4), não foi possível detectarmos o acúmulo do precursor $\mathrm{C}_{6}$-NBDceramida em parasitas tratados com MAPP e PDMP, o que pode ser explicado pelo grau de saturação da intensidade da banda obtida após aquisição da imagem da placa no scanner de fluorescência que impossibilitou qualquer análise comparativa entre os grupos. 


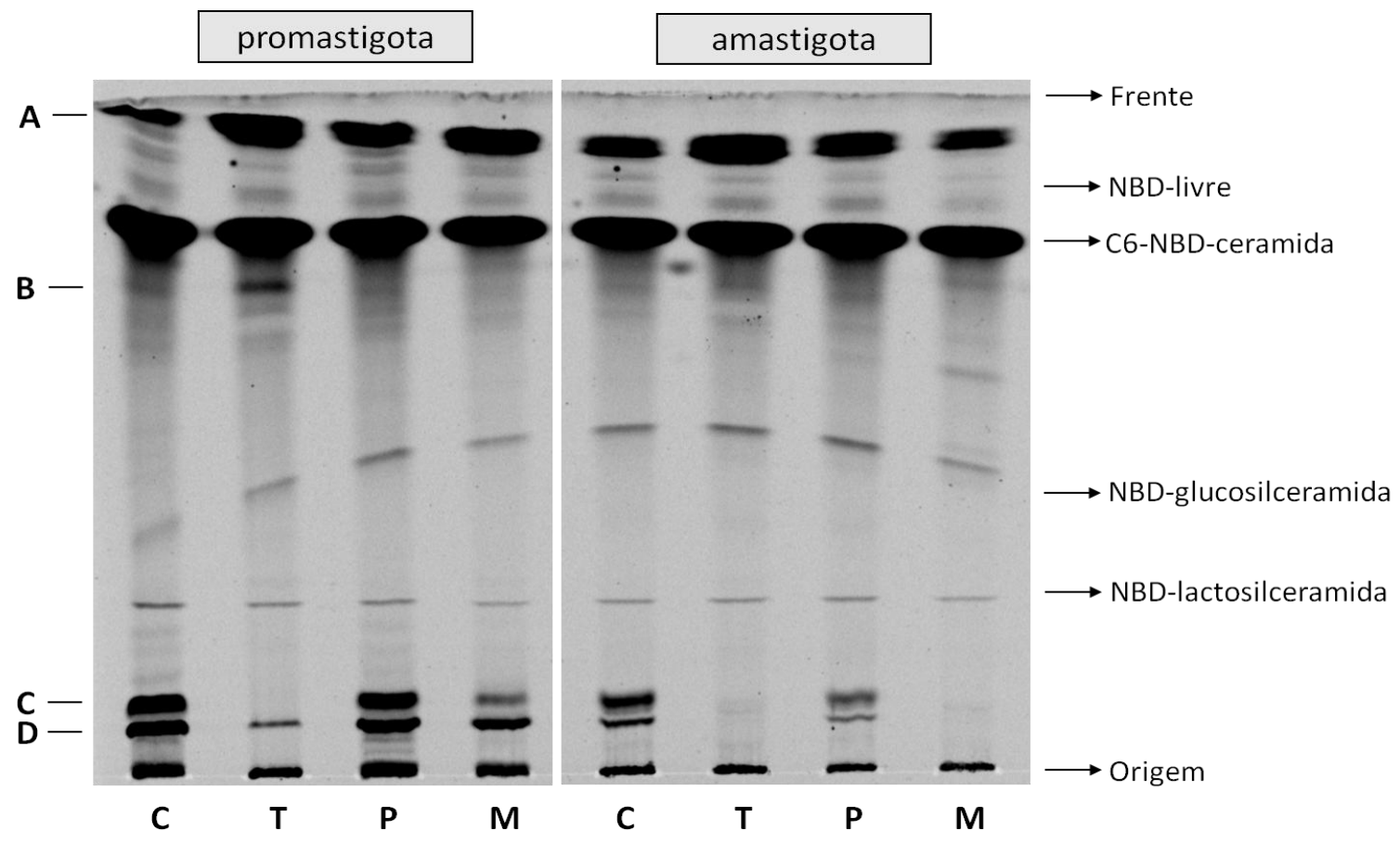

Figura 24. HPTLC do extrato lipídico de promastigotas ou amastigotas derivados de lesão de $L$. (L.) amazonensis incubados com $\mathbf{C}_{6}$-NBD-ceramida. $4 \times 10^{8}$ promastigotas (painel à esquerda) e $1 \times 10^{7}$ amastigotas (painel à direita) foram incubados na ausência (C) ou na presença de $10 \mu \mathrm{M}$ de tamoxifeno (T), $100 \mu \mathrm{M}$ de PDMP (P) ou $200 \mu \mathrm{M}$ de MAPP (M) por $1 \mathrm{~h}$ e 30 min para posterior incubação com $10 \mu \mathrm{M}$ de $\mathrm{C}_{6}$-NBDceramida por $2 \mathrm{~h}$ e $30 \mathrm{~min}$. Ao final do período, foram obtidos extratos lipídicos após 3 extrações sucessivas com clorofórmio:metanol:solução de Hanks/EDTA 10 mM (1:1:0,75; v:v:v) para separação por HPTLC com clorofórmio:metanol:água (60:35:8; v:v:v) para 20\% de corrida da placa e, para o restante, clorofórmio:metanol:ácido acético (90:2:8; v:v:v). As bandas foram visualizadas em leitor de fluorescência (STORM 840). À direita da figura estão indicados os Rfs para diferentes padrões incorporados com NBD, gentilmente cedidos pela Profa. Dra. Alica Couto. "A-D" correspondem às bandas identificadas por UVMALDI-TOF-MS.

As bandas A-D foram raspadas da sílica e re-extraídas para análise das amostras por UVMALDI-TOF-MS realizada no laboratório da Profa. Dra. Alicia Couto (Universidade de Buenos Aires, Argentina). Para a amostra referente à banda $A$, foi demonstrada a presença de $\mathrm{C}_{6}$-NBD-ceramida acilada (NBD-Cer+C2:0+K+) com $\mathrm{m} / \mathrm{z}$ 656,19 para parasitas do grupo controle (Figura 25A). No caso de parasitas tratados com tamoxifeno, detectou-se a presença não só de NBD-Cer+C2:0+K $\mathrm{K}^{+}(\mathrm{m} / \mathrm{z}$ 656,56), como também de outras NBD-ceramida aberrantes: NBD-Cer+C2:0+C14:1+K ${ }^{+}\left(\mathrm{m} / \mathrm{z}\right.$ 861,74) e NBD-Cer+C16:0+C16:0+Na ${ }^{+}(\mathrm{m} / \mathrm{z}$ 1.027,87) (Figura 25B). O tratamento com tamoxifeno levou à incorporação de cadeias acil de 14 e 16C, formas mais abundantes disponíveis para a biossíntese de ceramida em L. (L.) major (Hsu et al., 2007), à ceramida exógena. 

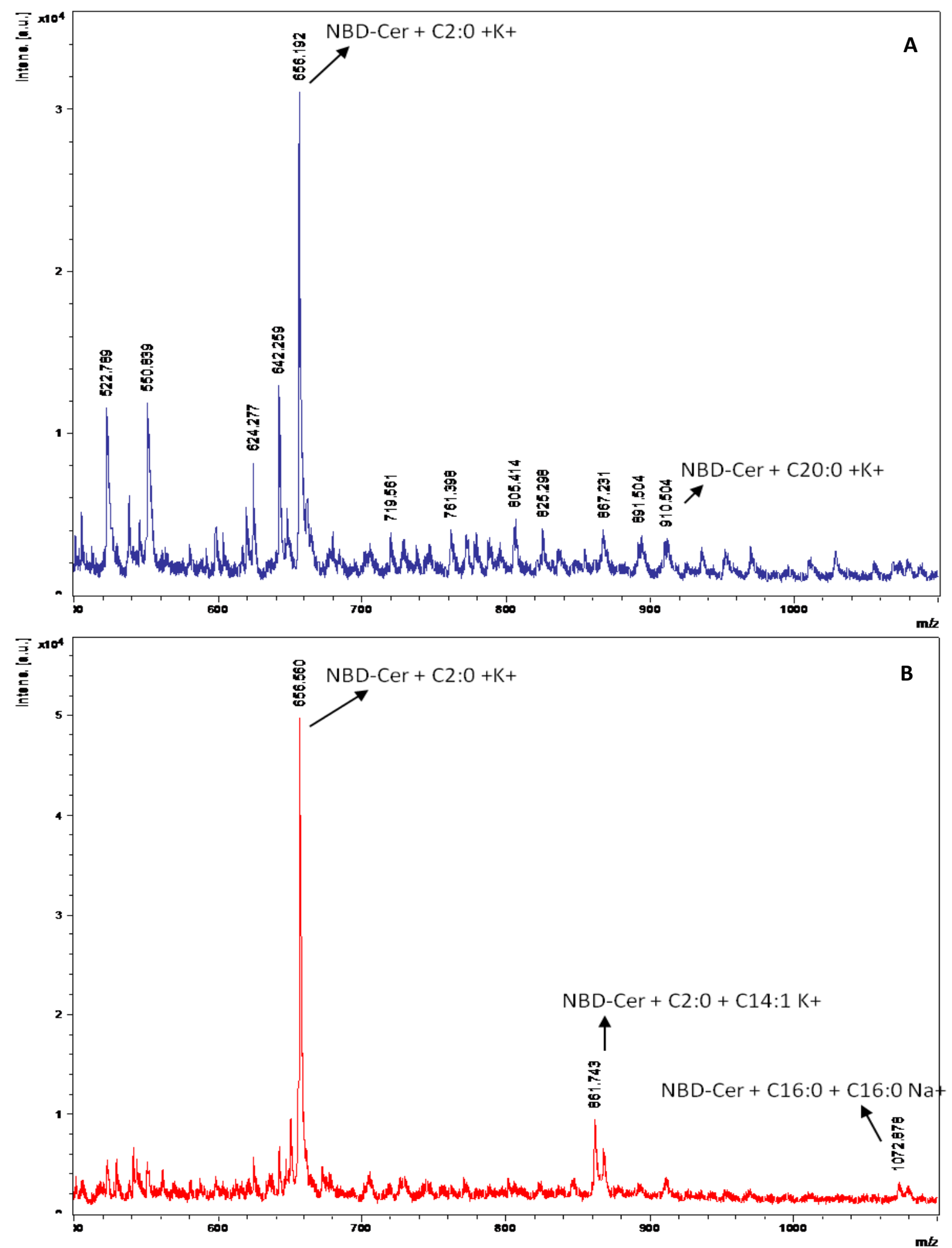

Figura 25. Análise por espectrometria de massas (UVMALDI-TOF) de amostras referentes à banda $A$ da placa mostrada na Figura 24, com análise pelo modo linear positivo. Em (A) está representado o espectro para a amostra do grupo de parasitas não-tratados com detecção do pico de maior abundância relativo ao íon NBD-Cer+C2:0+K $\mathrm{K}^{+} \operatorname{com} \mathrm{m} / \mathrm{z} 656,19$. Em (B) está apresentado o espectro para a banda $\mathrm{A}$ da amostra tratada com tamoxifeno, com destaque para os picos referentes aos íons NBD-Cer+C2:0+K ${ }^{+}$ $(\mathrm{m} / \mathrm{z}$ 656,56), NBD-Cer+C2:0+C14:1+K $(\mathrm{m} / \mathrm{z}$ 861,74) e NBD-Cer+C16:0+C16:0+Na $(\mathrm{m} / \mathrm{z} 1.027,87)$. 
Os resultados da análise para a amostra referente à banda $\mathrm{B}$ confirmaram a presença de $\mathrm{C}_{6}$-NBD-GC acetilada $(\mathrm{m} / \mathrm{z} 779,86)$ em nossos extratos (Figura 26). Quando foi aplicado o modo reflectron negativo, foi detectado o íon $\mathrm{m} / \mathrm{z}$ 615,04, condizente com a liberação de uma molécula de glicose da $\mathrm{C}_{6}-\mathrm{NBD}-\mathrm{GC}$ acetilada (Figura 27).

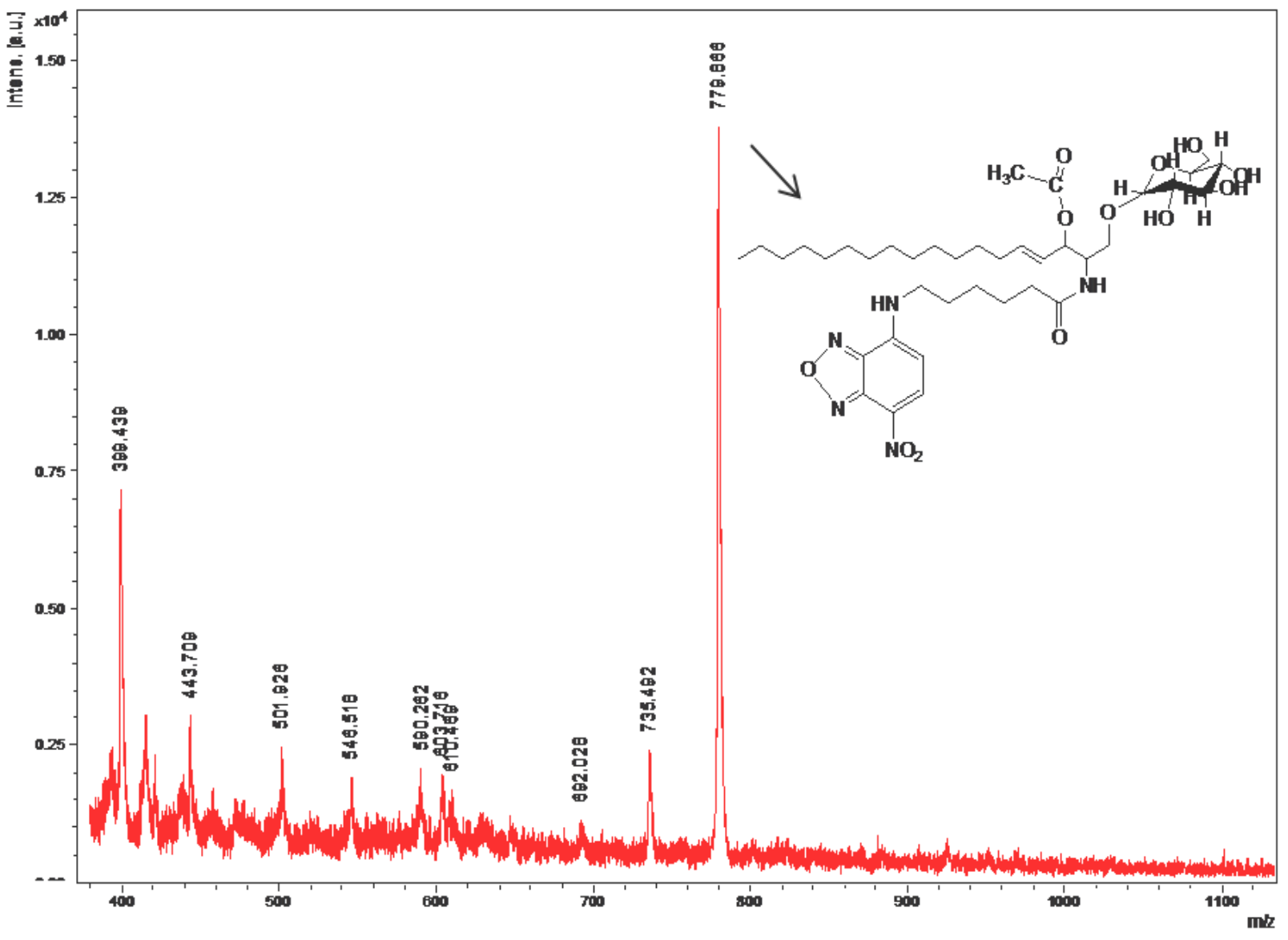

Figura 26. Análise por espectrometria de massas (UVMALDI-TOF) de amostras referentes à banda B da placa mostrada na Figura 24, com análise pelo modo linear negativo. Neste caso, foi detectado o espectro com pico maior abundância para a amostra do grupo de parasitas tratados e não tratados com tamoxifeno. $O$ íon molecular em questão apresenta $m / z$ 779,86 ( $C_{6}$-NBD-GC acetilada). A seta indica uma possível estrutura química para esta molécula. Notar a acetilação na base esfingoide. 


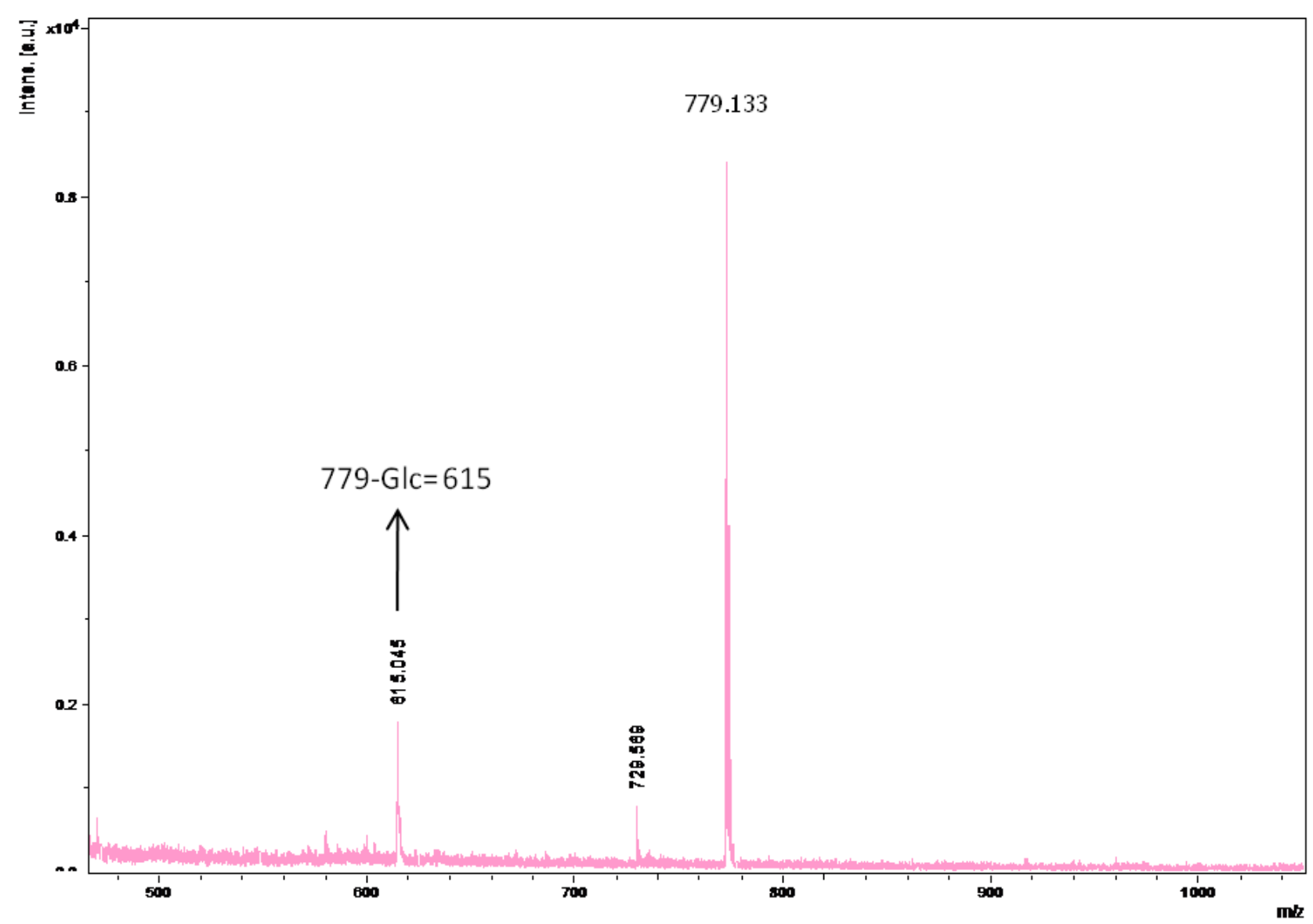

Figura 27. Análise por espectrometria de massas (UVMALDI-TOF) de amostras referentes à banda B da placa mostrada na Figura 24, com análise pelo modo de maior sensibilidade reflectron negativo. Íon $\mathrm{m} / \mathrm{z}$ 615,04 (à esquerda) é produto da clivagem in source do íon de maior abundância $\mathrm{m} / \mathrm{z} 779,13$ liberando uma molécula de glicose da $\mathrm{C}_{6}$-NBD-GC acetilada.

A partir destes resultados demonstramos que promastigotas de L. (L.) amazonensis são capazes de produzir GC a partir deste precursor, ainda que acetilada, sugerindo a presença de uma GC sintase. O acúmulo desta molécula poderia ser decorrente da inibição da incorporação de $\mathrm{C}_{6}$-NBD-ceramida em novos fosfoesfingolipídios resultando em um desvio metabólico para a biossíntese de glicoesfingolipídios. Esse achado indica ainda que, em L. (L.) amazonensis, o tamoxifeno não é um inibidor de GC sintase.

A análise das amostras referentes à banda C, tanto para parasitas não tratados como

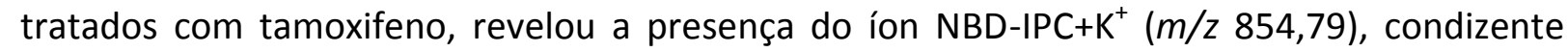
com a migração na placa de cromatografia para esfingolipídios carregados. $O$ aduto de $\mathrm{m} / \mathrm{z}$ 
909,99 referente ao íon NBD-NBD-PI+Na ${ }^{+}$também foi detectado aplicando-se o modo linear positivo (Figura 28A). Quanto à banda D, foi realizada também a análise por TOF aplicando-se o modo linear positivo. O íon de $\mathrm{m} / \mathrm{z}$ 824,68 foi identificado como NBD-PC-C18:0+Na+ (Figura 28B). Podemos observar que tamoxifeno reduziu tanto a biossíntese de IPC como de PC em promastigotas de L. (L.) amazonensis, quando oferecemos $\mathrm{C}_{6}$-NBD-ceramida como precursor metabólico. 


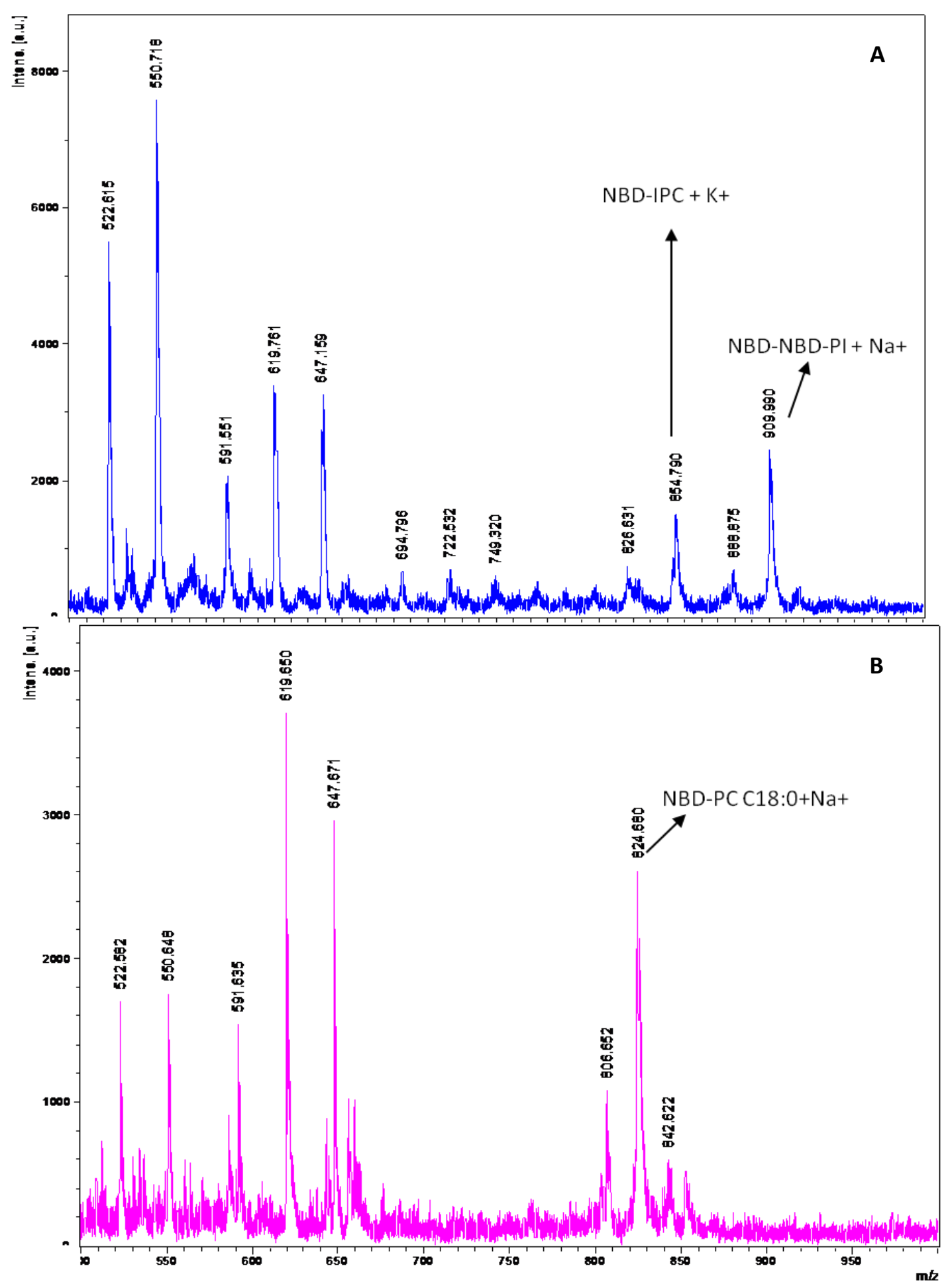

Figura 28. Análise por espectrometria de massas (UVMALDI-TOF) de amostras referentes às bandas $C$ e $D$ da placa mostrada na Figura 24, com análise pelo modo linear positivo. Em (A) está representado o espectro para a amostra do grupo de parasitas tratados e não-tratados referente à banda $\mathbf{C}$ da placa. Foi possível identificar os íons NBD-IPC+K ${ }^{+}\left(\mathrm{m} / z\right.$ 854,79) e NBD-NBD-PI+Na ${ }^{+}(\mathrm{m} / z$ 909,99). Para o espectro (B), tem-se a análise das amostras de parasitas tratados e não tratados referentes à banda $\mathbf{D}$ da placa. $\mathrm{O}$ íon NBD-PC-C18:0+Na $(\mathrm{m} / \mathrm{z} 824,68)$ foi identificado. 
Nossos dados mostram que a oferta de um precursor como a ceramida levou à sua incorporação pelas formas amastigotas e promastigotas e a assimilação predita em fosfoesfingolipídios, dada a abundância de IPC nestes parasitas (Kaneshiro et al., 1986). Contudo, de acordo com a intensidade das bandas obtidas em nossos ensaios de HPTLC, pudemos observar que uma importante fração do pool de ceramidas foi direcionada à síntese de ceramidas aciladas incomuns. Este resultado foi mais evidente tanto para promastigotas e amastigotas tratados com tamoxifeno, como para promastigotas tratados com MAPP (Figura 24).

Em estudo recentemente publicado, Chapman e co-autores demonstraram que a incubação de células da linhagem leucêmica mieloide aguda KG-1 com $5 \mu \mathrm{M}$ de tamoxifeno e meio contendo ácido palmítico tritiado por $24 \mathrm{~h}$, resulta em um aumento discreto na incorporação deste precursor em ceramidas de cadeia longa. O mesmo efeito é visto quando se utiliza $10 \mu \mathrm{M}$ de $\mathrm{C}_{6}$-NBD-ceramida combinada ao precursor radioativo. No entanto, quando tamoxifeno é combinado a $\mathrm{C}_{6}$-NBD-ceramida nas mesmas doses pelo mesmo período na presença do precursor, há um excessivo aumento na síntese de ceramida tritiada de cadeia longa. Este efeito sinérgico verificado pelos autores foi constatado de maneira mais marcante para a linhagem tumoral LoVo (câncer colorretal). Curiosamente, a associação [tamoxifeno $\mathrm{C}_{6}$-NBD-cer], nas concentrações utilizadas pelos autores, foi citotóxica para diversas linhagens tumorais avaliadas (Chapman et al., 2010). Além disso, o grupo também destacou que a maior parte da incorporação do precursor radioativo é maciçamente direcionada à síntese de esfingomielina e, em relação às células não tratadas, há redução drástica na incorporação em GC, o que justificaria o efeito do tamoxifeno muito similar ao do PDMP em células tumorais conforme já relatado na literatura (Cabot et al., 1996; Maceyka e Machamer, 1997; Basu et al., 2004). Contrariamente, mesmo utilizando concentrações próximas em nossos ensaios, nossos resultados mostraram que existe o direcionamento de parte do precursor $\mathrm{C}_{6}-\mathrm{NBD}$ ceramida para síntese da molécula de GC, que inclusive sofre acetilação (Figura 26). Portanto, a $\mathrm{C}_{6}$-NBD-ceramida acilada com diferentes cadeias carbônicas e a biossíntese de $\mathrm{C}_{6}$-NBD-GCacetilada foram eventos detectados para o tratamento com tamoxifeno. No entanto, foi possível detectar a presença de $\mathrm{C}_{6}$-NBD-ceramida acilada com cadeias de carbono adicionais curtas para células não tratadas, inclusive por HPTLC (Figura 24), o que nos leva a imaginar 
que o precursor $\mathrm{C}_{6}-\mathrm{NBD}$-ceramida possa apresentar toxicidade para os parasitas em cultura. Ensaios realizados em nosso laboratório incubando-se promastigotas de L. (L.) amazonensis com $10 \mu \mathrm{M}$ de $\mathrm{C}_{6}-\mathrm{NBD}$-ceramida por $24 \mathrm{~h}$ resultaram em 65-68\% de culturas viáveis. Apesar de termos utilizado períodos de incubação significativamente mais curtos ( 2 h e $30 \mathrm{~min}$ ) nos ensaios de marcação, não podemos descartar a ocorrência de um possível distúrbio metabólico, a partir de um eventual acúmulo do precursor que levaria à incapacidade de o parasita controlar a sua incorporação em outros intermediários ou produtos finais desta rota metabólica. Ensaios de cinética da viabilidade celular dos parasitas tratados com tamoxifeno e/ou incubados com $\mathrm{C}_{6}$-ceramida acompanhados do perfil de incorporação do precursor poderiam ser ferramentas úteis na tentativa de elucidarmos se tamoxifeno atuaria como agente amplificador do efeito citotóxico de $\mathrm{C}_{6}$-ceramida, como observado para determinadas linhagens tumorais (Chapman et al., 2010), em Leishmania. Vale relembrar que estes autores estabeleceram neste estudo, ainda, a propriedade de tamoxifeno modular o balanço na produção final de esfingolipídios de acordo com o tipo de linhagem tumoral. Por exemplo, em células LoVo tamoxifeno bloqueia a formação de $C_{6}-G C$ e redireciona $C_{6}$-ceramida à biossíntese de SM, efeito distinto daquele observado para células leucêmicas KG-1, para as quais o fármaco inibe síntese de $\mathrm{C}_{6}-\mathrm{GC}$ e $\mathrm{C}_{6}-\mathrm{SM}$. Em promastigotas de $L$. (L.) amazonensis, portanto, observamos o desvio da incorporação de $\mathrm{C}_{6}$-ceramida à $\mathrm{C}_{6}$ - $\mathrm{GC}$ e ceramidas aciladas e redução na incorporação de produtos fosforilados ( $C_{6}-I P C$ e $\left.C_{6}-P C\right)$.

Outra possibilidade a ser aventada seria a de tamoxifeno inibir a IPC sintase de Leishmania. Diversos análogos de ceramida foram recentemente sintetizados por Mina e colaboradores e, em ensaios realizados em um sistema de placa para varredura de compostos ativos na inibição de IPC sintase de L. (L.) major, mostraram-se ativos na redução da incorporação de $\mathrm{C}_{6} \mathrm{NBD}$-ceramida em C6-NBD-IPC, confirmando que a IPC sintase é um alvo bioquímico extremamente relevante no que diz respeito ao desenvolvimento de novos fármacos direcionados à sua inibição (Mina et al., 2010, 2011). Como perspectivas futuras, portanto, podemos definir estratégias para se determinar o efeito do tamoxifeno na atividade enzimática da IPC sintase de Leishmania.

Vale salientar também que o acúmulo de ceramida é um elemento fundamental da sinalização bioquímica na qual se baseia o controle de morte ou proliferação celular em 
células tumorais (Wang et al., 2003). Os níveis intracelulares desta molécula estão associados à modulação de eventos de apoptose (Basu et al., 2004) e também de morte celular por autofagia. Neste caso, tamoxifeno e PDMP são capazes de promover o acúmulo de ceramida, sinal que leva à dissociação do complexo [beclina I - Bcl2] com sinalização da molécula efetora beclina I para o processo de apoptose (Pattingre et al., 2009). Serapovic e colaboradores também demonstraram que células tumorais de mama da linhagem MCF-7 morrem por autofagia desencadeada por acúmulo de ceramida (Serapovic et al., 2010).

Diversas vias alternativas pertencentes ao metabolismo de ceramidas vem sendo propostas, dentre elas a de O-acilação das ceramidas (Abe e Shayman, 1998; revisado em Shayman 2000). Esta via consiste em um atrativo potencial para o estudo da incorporação de $\mathrm{C}_{6}$-ceramida (p. ex. em Leishmania) já que foi descrita a atividade de uma glicoproteína solúvel em água denominada fosfolipase $A_{2}$ lisossomal 1-0-acil-sintase de cérebro bovino capaz de utilizar os grupos acil de doadores como a PC e PE, este abundante em Leishmania, na acilação de ceramidas de cadeias curtas, aparentemente mais suscetíveis que as de cadeias longas (Hiraoka et al., 2002).

Nossos resultados apontam, portanto, que tamoxifeno altera o perfil de incorporação de $\mathrm{C}_{6}$-NBD-ceramida em esfingolipídios complexos de $L$. (L.) amazonensis, incluindo um efeito de acúmulo de GC acetilada e diminuição de fosfoesfingolipídios. Contudo, não podemos descartar o potencial citotóxico da própria $\mathrm{C}_{6}$-NBD-ceramida, conforme discutido acima. Com base nesta informação, lançamos mão de uma estratégia distinta de marcação com precursores anteriores à ceramida (NBD-esfingosina e NBD-esfinganina) que podem, inclusive, ser acilados com cadeias de ácidos graxos do parasita para posterior incorporação em outros esfingolipídios, o que representaria uma situação mais próxima ao perfil natural de biossíntese destas moléculas de Leishmania. Também ampliamos nossos ensaios acrescentando grupos de parasitas tratados com as drogas Fumonisina B1 e Aureobasidina A, inibidora da atividade de IPC sintase e ativa contra Leishmania (Tanaka et al., 2007). As amostras estão processo de análise por espectrometria de massas que certamente auxiliarão na identificação das moléculas tanto de parasitas do grupo controle como daqueles tratados com tamoxifeno. Além disso, experimentos utilizando preparações microssomais de parasitas estão em andamento no laboratório com o objetivo de avaliarmos a atividade in vitro de 
enzimas como a ceramidase e ceramida sintase na ausência ou presença de seus inibidores clássicos MAPP e Fumonisina B1.

\subsection{Aperfeiçoamento de estratégias experimentais para avaliação da atividade de drogas contra Leishmania}

\subsubsection{Estabelecimento de linhagem de L. (L.) amazonensis expressora do gene LUC}

Uma das linhas de pesquisa em curso no nosso laboratório concentra-se na identificação de compostos com atividade leishmanicida. Diferentes colaborações vem sendo estabelecidas entre nosso grupo e demais pesquisadores que tem o interesse em sintetizar moléculas e testá-las quanto às suas atividades contra Leishmania. Neste contexto ainda podemos incluir os compostos a serem sintetizados utilizando moléculas da família dos SERMs como protótipos, por ex. tamoxifeno e raloxifeno. De posse de uma gama de compostos a serem sintetizados e testados, torna-se ideal a padronização de um ensaio de high-throughput screening tanto para formas promastigotas quanto para os amastigotas intracelulares. Pensando em facilitar esta abordagem, estabelecemos em nosso laboratório uma linhagem de L. (L.) amazonensis que expressa o gene contendo a ORF que codifica a enzima luciferase. Após a construção do plasmídio pXG1Luc realizada pela aluna de Mestrado Sandra Kalil (Kalil, 2011), transfectamos este plasmídio em promastigotas de L. (L.) amazonensis conforme descrito na sessão Materiais e Métodos. O plasmídio pXG1 possui, ainda, a ORF que codifica o gene de resistência ao antibiótico geneticina. Assim, para seleção dos clones transfectados, as culturas foram mantidas na presença do antibiótico. O fenótipo dos parasitas foi avaliado a partir de ensaios enzimáticos de atividade da luciferase (ver esquema Figura 30A). No caso das formas promastigotas estabelecemos uma correlação positiva entre o número de parasitas e as unidades de luminescência captadas em luminômetro após a reação enzimática incubando-se luciferina com os extratos de parasitas (dados não apresentados). Para verificarmos se este ensaio poderia ser adotado como estratégia para avaliação da inibição de 
infecções por Leishmania in vitro (formas amastigotas intracelulares), incubamos as células infectadas com anfotericina B. Duplicatas experimentais foram analisadas por microscopia ou submetidas à preparação do lisado para incubação com luciferina e posterior análise em luminômetro (Figura 30B). Podemos verificar que os perfis de resposta de inibição foram equivalentes para os diferentes métodos de quantificação de viabilidade celular, já que os valores de $\mathrm{IC}_{50}$ calculados foram $0,038 \pm 0,003 \mu \mathrm{M}$ na análise por luminescência e 0,025 \pm $0,003 \mu \mathrm{M}$ para contagem das infecções. Vale ressaltar que estes resultados apontam para a aplicabilidade desta técnica em ensaios de atividade de inibição de Leishmania in vitro em larga escala, pois se torna possível estabelecer a redução das porcentagens de infecção de células tratadas em relação ao grupo de células não tratadas (controle). No entanto, a aplicação desta metodologia para avaliação de inibição de infecções in vitro pode ser limitada quando se deseja averiguar o parâmetro "replicação" a partir do número de parasitas por macrófago, informação conseguida, portanto, a partir da contagem microscópica de amastigotas por célula hospedeira.

A
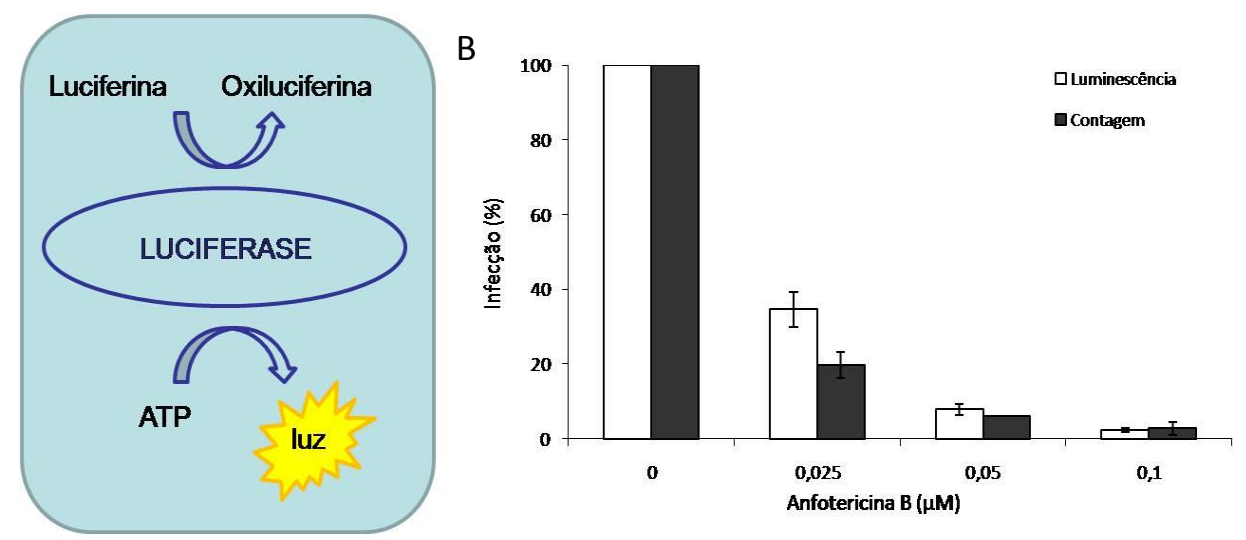

Figura 30. Atividade enzimática da luciferase em parasitas transfectados. A: Na reação de luminescência, a luz é produzida pela oxidação da luciferina, dependente de ATP. B: Inibição de infecção de macrófagos por L. (L.) amazonensis após tratamento com diferentes concentrações de anfotericina B por 48 h. Os parasitas utilizados para infecção (5 promastigotas por macrófago) foram transfectados com o gene da luciferase. Para avaliação da redução nas taxas de infeç̧ão realizamos a quantificação da luminescência (barras brancas) e, simultaneamente, foram estabelecidas as porcentagens de infecção a partir da contagem de células infectadas em lamínulas em microscópio ótico (barras pretas). As linhas menores indicam o desvio-padrão da média de três contagens para cada dose testada. 


\subsection{Participação em projetos paralelos}

Ao longo do período em que esta tese foi desenvolvida o aluno participou diretamente de diversas colaborações científicas envolvendo o estudo de novas abordagens quimioterápicas contra protozoários. Os artigos científicos resultantes destes trabalhos estão listados a seguir:

1. Caracterização da atividade dos doadores de NO SNAC (S-nitroso-N-acetil-L-cisteína) e GSNO (S-nitrosoglutationa) contra Leishmania.

SOUZA GFP, YOKOYAMA-YASUNAKA JKU, SEABRA AB, MIGUEL DC, OLIVEIRA MG, ULIANA SRB. Leishmanicidal activity of primary S-nitrosothiols against Leishmania major and Leishmania amazonensis: implications for the treatment of cutaneous leishmaniasis. Nitric Oxide - Biology and Chemistry, v. 15, p. 209-216, 2006.

2. Avaliação da eficácia de limoneno in vitro e in vivo contra Leishmania.

ARRUDA DC, MIGUEL DC, YOKOYAMA-YASUNAKA JKU, KATZIN AM, ULIANA SRB. Inhibitory activity of limonene against Leishmania parasites in vitro. Biomedicine \& Pharmacotherapy, v. 63, p. 643-649, 2009.

3. Caracterização do potencial leishmanicida in vitro de metalodrogas (complexos de $\mathrm{Cu}(\mathrm{II})$.

MAFFEI R, YOKOYAMA-YASUNAKA JKU, MIGUEL DC, ULIANA SRB, ESPOSITO BP. Synthesis, characterization and evaluation of antileishmanial activity of copper (II) with fluorinated alphahydroxycarboxylate ligands. BioMetals (Oxford), v. 22, p. 1095-1101, 2009.

4. Avaliação do potencial leishmanicida e tripanossomicida in vitro de derivados de limoneno.

GRAEBIN CS, MADEIRA MF, YOKOYAMA-YASUNAKA JKU, MIGUEL DC, ULIANA SRB, BENITEZ D, CERECETTO H, GONZÁLEZ M, ROSA R, EIFLER-LIMA VL. Synthesis and in vitro activity of limonene derivatives against Leishmania and Trypanosoma. European Journal of Medicinal Chemistry, v. 45, p. 1524-1528, 2010.

5. Análise do padrão de sensibilidade de isolados de Leishmania de pacientes aos medicamentos usados na clínica

ZAULI-NASCIMENTO RC, MIGUEL DC, YOKOYAMA-YASUNAKA JKU, PEREIRA LIA, OLIVEIRA M, RIBEIRODIAS F, DORTA ML, ULIANA SRB. In vitro sensitivity of Leishmania (Viannia) braziliensis and Leishmania (Leishmania) amazonensis Brazilian isolates to meglumine antimoniate and amphotericin B. Tropical Medicine and International Health, v. 15, p. 68-76, 2010.

6. Investigação do potencial antimalárico de risedronato e de sua interferência na isoprenilação de proteínas de $P$. falciparum

JORDÃO FM, SAITO AY, MIGUEL DC, PERES VD, KIMURA EA, KATZIN AM. In vitro and in vivo antiplasmodial activity of risedronate and its interference with protein prenylation in $P$. falciparum. Antimicrob Agents and Chemotherapy. v. 55(5), p. 2026- 2031, 2011. 


\section{CONCLUSÕES}


A partir dos resultados apresentados na presente tese concluímos que tamoxifeno apresenta atividade leishmanicida in vitro na faixa de concentração de micromolar para diferentes espécies do parasita. Sua eficácia foi comprovada contra formas axênicas e intracelulares tanto para cepas de laboratório como para isolados recentes de pacientes. Este fármaco também se mostrou eficaz no controle de infecções experimentais para as formas cutânea e visceral da doença, preferencialmente por administração via intraperitoneal. Além disso, tamoxifeno foi ativo contra formas de cultura de Trypanosoma cruzi. Um dos metabólitos do tamoxifeno (4-hidróxi-tamoxifeno) e outros membros da família dos SERMs (raloxifeno e toremifeno) também apresentaram efeito leishmanicida.

Apesar da atividade de tamoxifeno contra formas amastigotas não ter sido atribuída à modulação do $\mathrm{pH}$ de vacúolos fagolisossômicos, seu efeito foi potencializado após a alcalinização dessas organelas. Tamoxifeno não elevou os níveis de nitrito em sobrenadantes de infecções por Leishmania e nem a expressão de iNOS de macrófagos infectados, portanto, seu efeito também não está relacionado à indução da atividade microbicida de NO.

Estudos bioquímicos apontaram que tamoxifeno não altera de forma específica a biossíntese de isoprenoides de Leishmania, mas mostraram que este é capaz de permeabilizar a membrana plasmática de promastigotas. Essa permeabilização pode ser devida à partição de tamoxifeno na membrana plasmática, sugerida por ensaios de fracionamento que indicam que parte da droga fica retida nesta estrutura. Alterações mitocondriais e extensa vacuolização citoplasmática também foram verificadas em parasitas tratados com o fármaco.

A investigação da interferência de tamoxifeno no metabolismo de esfingolipídios de Leishmania proporcionou, primeiramente, a caracterização da atividade leishmanicida de inibidores de ceramidase e GC sintase de mamíferos. Demonstramos que tamoxifeno alterou o perfil de incorporação de ceramida em promastigotas de $L$. (L.) amazonensis de forma a desencadear o acúmulo de espécies aberrantes de ceramidas aciladas, o aumento no nível de GC acetilada e a redução na formação de fosfoesfingolipídios. Apesar do mecanismo de ação do tamoxifeno não ter sido completamente elucidado, os resultados apresentados aqui evidenciam que tamoxifeno é capaz de interferir drasticamente na via de biossíntese de esfingolipídios de Leishmania. 


\section{REFERÊNCIAS}




\section{REFERÊNCIAS*}

Abe A, Wu D, Shayman JA, Radin NS. Metabolic effects of short-chain ceramide and glucosylceramide on sphingolipids and protein kinase C. Eur J Biochem. 1992;210(3):765-73.

Achterberg V, Gercken G. Cytotoxicity of ester and ether lysophospholipids on Leishmania donovani promastigotes. Mol Biochem Parasitol. 1987;23(2):117-22.

Adam HK, Douglas EJ, Kemp JV. The metabolism of tamoxifen in human. Biochem Pharmacol. 1979;28(1):145-7.

Afonso IC, Scott P. Immune responses associated with susceptibility of c57bl/10 mice to Leishmania amazonensis. Infect immun. 1993;61(7):2952-9.

Al-Mutairi N, Alshiltawy M, El Khalawany M, Joshi A, Eassa BI, Manchanda Y, Gomaa S, Darwish I, Rijhwani M. Tropical medicine rounds: Treatment of Old World cutaneous leishmaniasis with dapsone, itraconazole, cryotherapy, and imiquimod, alone and in combination. Int J Dermatol. 2009;48(8):862-9.

Alexandrino-de-Oliveira P, Santos-Oliveira JR, Dorval ME, Da-Costa FC, Pereira GR, da Cunha RV, Paniago AM, Da-Cruz AM. HIV/AIDS-associated visceral leishmaniasis in patients from an endemic area in Central-west Brazil. Mem Inst Oswaldo Cruz. 2010;105(5):692-7.

Ali S, Coombes RC. Endocrine-responsive breast cancer and strategies for combating resistance. Nat Rev Cancer. 2002;2(2):101-12.

All-Party Parliamentary Malaria Group (APPMG). APPMG, 2008/9 - The Neglected Tropical Diseases: A challenge we could rise to - Will we? Available from: www.appmg-malaria.org.uk [2011 Feb 22].

Alphonse G, Bionda C, Aloy MT, Ardail D, Rousson R, Rodriguez-Lafrasse C. Overcoming resistance to gamma-rays in squamous carcinoma cells by poly-drug elevation of ceramide levels. Oncogene. 2004;23(15):2703-15.

*De acordo com:

International Committee of Medical Journal Editors. Uniform requirements for manuscripts submitted to Biomedical Journal: sample references. C2003-Available from: http://www.icmje.org [2004 May 06]. 
Altan N, Chen $\mathrm{Y}$, Schindler M, Simon SM. Defective acidification in human breast tumor cells and implications for chemotherapy. J. Exp Med. 1998;187(10):1583-98.

Altan N, Chen $\mathrm{Y}$, Schindler M, Simon SM. Tamoxifen inhibits acidification in cells independent of the estrogen receptor. Proc Natl Acad Sci U.S.A. 1999;96(8):4432-7.

Alvar J, Aparicio P, Aseffa A, Den Boer M, Cañavate C, Dedet JP, Gradoni L, Ter Horst R, López-Vélez R, Moreno J. The relationship between leishmaniasis and AIDS: the second 10 years. Clin Microbiol Rev. 2008;21(2):334-59.

Amato VS, Tuon FF, Siqueira AM, Nicodemo AC, Neto VA. Treatment of mucosal leishmaniasis in Latin America: systematic review. Am J Trop Med Hyg. 2007;77: 266-74.

Ameen M. Cutaneous leishmaniasis: advances in disease pathogenesis, diagnostics and therapeutics. Clin Exp Dermatol. 2010;35(7):699-705.

Andersen EM, Cruz-Saldarriaga M, Llanos-Cuentas A, Luz-Cjuno M, Echevarria J, Miranda-Verastegui C, Colina O, Berman JD. Comparison of meglumine antimoniate and pentamidine for peruvian cutaneous leishmaniasis. Am J Trop Med Hyg. 2005;72(2):133-7.

Armijos RX, Weigel MM, Calvopiña M, Mancheno M, Rodriguez R. Comparison of the effectiveness of two topical paromomycin treatments versus meglumine antimoniate for New World cutaneous leishmaniasis. Acta Trop. 2004;91(2):153-60.

Arruda DC, Miguel DC, Yokoyama-Yasunaka JKU, Katzin AM, Uliana SR. Inhibitory activity of limonene against Leishmania parasites in vitro and in vivo. Biomed Pharmacother. 2009;63(9):643-9.

Ashford RW. The leishmaniasis as emerging and reemerging zoonoses. Int J Parasitol. 2000;30(1213):1269-81.

Asilian A, Jalayer T, Nilforooshzadeh M, Ghassemi RL, Peto R, Wayling S, Olliaro P, Modabber F. Treatment of cutaneous leishmaniasis with aminosidine(paromomycin)ointment: double-blind, randomized trial in the Islamic Republic of Iran. Bull World Health Organ. 2003;81(5):353-9.

Azzouz S, Maache M, Garcia RG, Osuna A. Leishmanicidal activity of edelfosine, miltefosine and ilmofosine. Basic Clin Pharmacol Toxicol. 2005;96(1):60-5. 
Barral A, Pedral Sampaio D, Grimaldi GJr, Momen H, McMachon-Pratt D, Jesus AR, Almeida R, Badaró $R$, Barral-Neto $M$, Carvalho EM, Johnson JR WD. Leishmaniasis in Bahia, Brazil: evidence that Leishmania amazonensis produces a wide spectrum of clinical disease. Am J Trop Med Hyg. 1991;44(5):536-46.

Barral-Netto M, Roters SB, Sherlock I, Reed SG. Destruction of Leishmania mexicana amazonensis promastigotes by normal human serum. Am J Trop Med Hyg. 1987;37(1):53-6.

Barreto-Bergter E, Pinto MR, Rodrigues ML. Structure and biological functions of fungal cerebrosides. An Acad Bras Cienc. 2004;76(1):67-84.

Basu S, Kaufman B, Roseman S. Enzymatic synthesis of ceramide-glucose and ceramide-lactose by glycosyltransferases from embryonic chicken brain. J Biol Chem. 1968;243(21):5802-4.

Basu S, Ma R, Boyle PJ, Mikulla B, Bradley M, Smith B, Basu M, Banerjee S. Apoptosis of human carcinoma cells in the presence of potential anti-cancer drugs: III. Treatment of Colo-205 and SKBR3 cells with: cis -platin, Tamoxifen, Melphalan, Betulinic acid, L-PDMP, L-PPMP, and GD3 ganglioside. Glycoconj J. 2004;20(9):563-77.

Basso AD, Mirza A, Liu G, Long BJ, Bishop WR, Kirshmeier P. The farnesyl transferase inhibitor (FTI) $\mathrm{SCH} 66336$ (lonafarnib) inhibits Rheb farnesylation and mTOR signaling. Role in FTI enhancement of taxane and tamoxifen anti-tumor activity. J Biol Chem. 2005;280(35):31101-8.

Bates PA. The developmental biology of Leishmania promastigotes. Exp Parasitol. 1994;79(2):215-8.

Bathia A, Kumar R, Katare OP. Tamoxifen in topical liposomes: development, characterization and in vitro evaluation. J Pharm Pharm Sci. 2004;7(2):252-9.

Bera A, Singh S, Nagaraj R, Vaidya T. Induction of autophagic cell death in Leishmania donovani by antimicrobial peptides. Mol Biochem Parasitol. 2003;127(1):23-35.

Berman JD, Gallalee JV, Best JM. Sodium stibogluconate (Pentostam) inhibition of glucose catabolism via the glycolytic pathway, and fatty acid beta-oxidation in Leishmania mexicana amastigotes. Biochem Pharmacol. 1987;36(2):197-201.

Bern C, Chowdhury R. The epidemiology of visceral leishmaniasis in Bangladesh: prospects for improved control. Indian J Med Res. 2006;123:275-88. 
Bern C, Maguire JH, Alvar J. Complexities of assessing the disease burden attributable to leishmaniasis. PLoS NegI Trop Dis. 2008;2(10): e313.

Bernstein L, Deapen D, Cerhan JR, Schwartz SM, Liff J, Mcgann-Maloney E, Perlman JA, Ford L. Tamoxifen therapy for breast cancer and endometrial cancer risk. J Natl Cancer Inst. 1999,91(19):165462.

Bevilacqua PD, Paixão HH, Modena CM, Castro MCPS. Urbanização da leishmaniose visceral em Belo Horizonte. Arq Bras Med Vet Zootec. 2001;53:1-8.

Bielawska A, Linardic CM, Hannun YA. Ceramide-mediated biology. Determination of structural and stereospecific requirements through the use of $\mathrm{N}$-acyl-phenylaminoalcohol analogs. J Biol Chem. 1992;267(26):18493-7.

Bielawska A, Greenberg MS, Perry D, Jayadev S, Shayman JA, McKay C, Hannun YA. (1S,2R)-D-erythro2-(N-myristoylamino)-1-phenyl-1-propanol as an inhibitor of ceramidase. J Biol Chem. 1996;271(21):12646-54.

Blum J, Desjeux P, Schwartz E, Beck B, Hatz C. Treatment of cutaneous leishmaniasis among travellers. J Antimicrob Chemother. 2004;53(2):158-66.

Boath A, Graf C, Lidome E, Ullrich T, Nussbaumer P, Bornancin F. Regulation and traffic of ceramide 1phosphate produced by ceramide kinase: comparative analysis to glucosylceramide and sphingomyelin. J Biol Chem. 2008;283(13):8517-26.

Botelho AC, Natal D. First epidemiological description of visceral leishmaniasis in Campo Grande, State of Mato Grosso do Sul. Rev Soc Bras Med Trop. 2009;42(5):503-8.

Brasil. Ministério da Saúde. Secretaria de Vigilância em Saúde (SINAN/SVS/MINISTÉRIO DA SAÚDE). Casos confirmados de Leishmaniose Tegumentar Americana. Brasil, Grandes Regiões e Unidades Federadas. $\quad 1990202010.2009$ D 201 em: http://portal.saude.gov.br/portal/arquivos/pdf/1 Ita casos $27 \quad 10$ 2010.pdf [21 Mar 11].

Brasil. Ministério da Saúde. Secretaria de Vigilância em Saúde (SINAN/SVS/MINISTÉRIO DA SAÚDE). Casos confirmados de Leishmaniose Visceral, Brasil, Grandes Regiões e Unidades Federadas. 1990 a 2009. 2010. Disponível em: http://portal.saude.gov.br/portal/arquivos/pdf/2 Iv casos 1410 10.pdf [20 Fev 2011]. 
Brasil. Ministério da Saúde. Secretaria de Vigilância em Saúde (SVS-FIOCRUZ/MINISTÉRIO DA SAÚDE). Monitoramento e Vigilância da Leishmaniose Tegumentar no Brasil. 2011. Disponível em: http://www4.ensp.fiocruz.br/Leishmaniose/lt/ [21 Mar 2011].

Bray PG, Barret MP, Ward SA, De Koning HP. Pentamidine uptake and resistance in pathogenic protozoa: past, present and future. Trends Parasitol. 2003;19(5):232-9.

Brener Z, Chiari E. Morphological variations observed in different strains of Trypanosoma cruzi. Rev Inst Med Trop Sao Paulo. 1963;5:220-4.

Brown M, Noursadeghi M, Boyle J, Davidson RN. Successful liposomal amphotericin B treatment of Leishmania braziliensis cutaneous leishmaniasis. Br J Dermatol. 2005;153(1):203-5.

Cabot MC, Giuliano AE, Volner A, Han TY. Tamoxifen retards glycosphingolipid metabolism in human cancer cells. FEBS Lett. 1996;394(2):129-31.

Camargo EP. Growth and differentiation in Trypanosoma cruzi. I. Origin of metacyclic trypanosomes in liquid media. Rev Inst Med Trop Sao Paulo. 1964;6:93-100.

Chapman JV, Gouazé-Andersson V, Messner MC, Flowers M, Karimi R, Kester M, Barth BM, Liu X, Liu YY, Giuliano AE, Cabot MC. Metabolism of short-chain ceramide by human cancer cells - implications for therapeutic approaches. Biochem Pharmacol. 2010 Aug 1;80(3):308-15.

Chen $Y$, Shindler M, Simon SM. A mechanism for tamoxifen-mediated inhibition of acidification. J Biol Chem. 1999;274(26):18364-73.

Chojnacki T, Dallner G. The biological role of dolichol. Biochem J. 1988;251(1):1-9.

Chrusciak-Talhari A, Dietze R, Chrusciak Talhari C, da Silva RM, Gadelha Yamashita EP, de Oliveira Penna G, Lima Machado PR, Talhari S. Randomized controlled clinical trial to access efficacy and safety of miltefosine in the treatment of cutaneous leishmaniasis caused by Leishmania (Viannia) guyanensis in Manaus, Brazil. Am J Trop Med Hyg. 2011;84(2):255-60.

Chunge CN, Owate J, Pamba HO, Donno L. Treatment of visceral leishmaniasis in Kenya by aminosidine alone or combined with sodium stibogluconate. Trans R Soc Trop Med Hyg. 1990;84(2):221-5.

Coburn C, Beverley S. Procedures for transfection of higher trypanosomatids. Boston: Harvard Medical School; 1990. 
Coimbra ES, Libong D, Cojean S, Saint-Pierre-Chazalet M, Solgadi A, Le Moyec L, Duenas-Romero AM, Chaminade $\mathrm{P}$, Loiseau PM. Mechanism of interaction of sitamaquine with Leishmania donovani. J Antimicrob Chemother. 2010;65(12):2548-55.

Convit J, Ulrich M, Fernandez CT, Tapia FJ, Caceres-Dittmar G, Castés M, Rondón AJ. The clinical and immunological spectrum of American cutaneous leishmaniasis. Trans R Soc Trop Med Hyg. 1993;87:444-8.

Croft SL, Coombs GH. Leishmaniasis - current chemotherapy and recent advances in the search for novel drugs. Trends Parasitol. 2003;19(11):502-8.

Croft SL, Seifert K, Yardley V. Current scenario of drug development for leishmaniasis. Indian J Med Res. 2006;123(3):399-410.

Cruz Silva MM, Madeira VM, Almeida LM, Custódio JB. Hemolysis of human erythrocytes induced by tamoxifen is related to disruption of membrane structure. Biochim Biophys Acta. 2000;1464(1):49-61.

Cunningham ML, Fairlamb AH. Trypanothione reductase from Leishmania donovani. Purification, characterisation and inhibition by trivalent antimonials. Eur J Biochem. 1995;230(2):460-8.

Custódio JB, Almeida LM, Madeira VM. A reliable and rapid procedure to estimate drug partitioning in biomembranes. Biochem Biophys Res Commun. 1991;176(3):1079-85.

Custódio JB, Dinis TC, Almeida LM, Madeira VM. Tamoxifen and hydroxytamoxifen as intramembraneous inhibitors of lipid peroxidation. Evidence for peroxyl radical scavenging activity. Biochem Pharmacol. 1994;47(11):1989-98.

Das P, Lahiri A, Lahiri A, Chakravortty D. Modulation of the arginase pathway in the context of microbial pathogenesis: A metabolic enzyme moonlighting as a immune modulator. PLoS Pathogens. 2010;6(6):e1000899.

Denny PW, Goulding D, Ferguson MA, Smith DF. Sphingolipid-free Leishmania are defective in membrane trafficking, differentiation and infectivity. Mol Microbiol. 2004;52(2):313-27.

Desjeux P. Prevention of Leishmania donovani infection. BMJ. 2010;341:c6751. 
Ding $\mathrm{AH}$, Nathan $\mathrm{CF}$, Stuehr DJ. Release of reactive nitrogen intermediates and reactive oxygen intermediates from mouse peritoneal macrophages. Comparison of activating cytokines and evidence for independent production. J Immunol. 1988;141(7):2407-12.

Dujardin JC, González-Pacanowska D, Croft SL, Olesen OF, Späth GF. Collaborative actions in antitrypanosomatid chemotherapy with partners from disease endemic areas. Trends Parasitol. 2010; 26(8):395-403.

El-Kattan AF, Asbill CS, Kim N, Michniak BB. The effects of terpene enhancers on the percutaneous permeation of drugs with different lipophilicities. Int J Pharm. 2001;215:229-40.

El-Sayed NM, Myler PJ, Blandin G, Berriman M, Crabtree J, Aggarwal G, Caler E, Renauld H, Worthey EA, Hertz-Fowler C, Ghedin E, Peacock C, Bartholomeu DC, Haas BJ, Tran AN, Wortman JR, Alsmark UC, Angiuoli S, Anupama A, Badger J, Bringaud F, Cadag E, Carlton JM, Cerqueira GC, Creasy T, Delcher AL, Djikeng A, Embley TM, Hauser C, Ivens AC, Kummerfeld SK, Pereira-Leal JB, Nilsson D, Peterson J, Salzberg SL, Shallom J, Silva JC, Sundaram J, Westenberger S, White O, Melville SE, Donelson JE, Andersson B, Stuart KD, Hall N. Comparative genomics of trypanosomatid parasitic protozoa. Science. 2005;15;309(5733):404-9.

El-Sayed M, Anwar AE. Intralesional sodium stibogluconate alone or its combination with either intramuscular sodium stibogluconate or oral ketoconazole in the treatment of localized cutaneous leishmaniasis: a comparative study. J Eur Acad Dermatol Venereol. 2010;24(3):335-40.

Faust JR, Goldstein JL, Brown MS. Squalene synthetase activity in human fibroblasts: regulation via the low density lipoprotein receptor. Proc Natl Acad Sci U.S.A. 1979;76(10):5018-22.

Feasey N, Wansbrough-Jones M, Mabey DC, Solomon AW. Neglected Tropical diseases. Brit Med Bull. 2010;93:179-200.

Figueiredo JM, Dias WB, Mendonça-Previato L, Previato JO, Heise N. Characterization of the inositol phosphorylceramide synthase activity from Trypanosoma cruzi. Biochem J. 2005;387(Pt 2):519-29.

Figueiredo JM. Caracterização molecular e funcional da ceramida sintase dependente de acil-CoA em Trypanosoma cruzi. [tese (Doutorado em Ciências)]. Rio de Janeiro (Brasil): Centro de Ciências da Saúde - Instituto de Biofísica Carlos Chagas Filho da Universidade Federal do Rio de Janeiro; 2008.

Filardi LS, Brener Z. Susceptibility and natural resistance of Trypanosoma cruzi strains to drugs used clinically in Chagas disease. Trans R Soc Trop Med Hyg. 1987;81:755-9. 
Franke ED, Lucas CM, Tovar AA, Kruger JH, De Rivera MV, Wignall FS. Diffuse cutaneous leishmaniasis acquired in Peru. Am J Trop Med Hyg. 1999;43:260-2.

Fumarola L, Spinelli R, Brandonisio O. In vitro assays for evaluation of drug activity against Leishmania spp. Res Microbiol. 2004;155(4):224-30.

Ginger ML, Chance ML, Sadler IH, Goad LJ. The biosynthetic incorporation of the intact leucine skeleton into sterol by the trypanosomatid Leishmania mexicana. J Biol Chem. 2001;276(15):11674-82.

Gelmann EP. Tamoxifen for the treatment of malignancies other than breast and endometrial carcinoma. Semin Oncol. 1997;24(1 Suppl 1):S1-65-S1-70.

Genestra M, Soares-Bezerra RJ, Gomes-Silva L, Fabrino DL, Bellato-Santos T, Castro-Pinto DB, CantoCavalheiro MM, Leon LL. In vitro sodium nitroprusside-mediated toxicity towards Leishmania amazonensis promastigotes and axenic amastigotes. Cell Biochem Funct. 2008;26(6):709-17.

Goldstein SR. Selective estrogen receptor modulators: a new category of compounds to extend postmenopausal women's health. Int J Fertil Womens Med. 1999;44(5):221-6.

Goldstein SR, Siddhanti S, Ciaccia AV, Plouffe LR. A pharmacological review of selective oestrogen receptor modulators. Hum Reprod Update. 2000;6(3):212-24.

Gonçalves GS, Fernandes AP, Souza RC, Cardoso JE, de Oliveira-Silva F, Maciel FC, Rabello A, Ferreira LA. Activity of a paromomycin hydrophilic formulation for topical treatment of infections by Leishmania (Leishmania) amazonensis and Leishmania (Viannia) braziliensis. Acta Trop. 2005;93(2):161-7.

Grimaldi GJR. Cutaneous leishmaniasis: clinical and immunophathological aspects. Mem Inst Oswaldo Cruz. 1992;77(2):195-215.

Guerra JA, Prestes SR, Silveira H, Coelho LI, Gama P, Moura A, Amato V, Barbosa MG, Ferreira LC. Mucosal Leishmaniasis Caused by Leishmania (Viannia) braziliensis and Leishmania (Viannia) guyanensis in the Brazilian Amazon. PLoS Negl Trop Dis. 2011;5(3): e980.

Hanada K, Kumagai K, Yasuda S, Miura Y, Kawano M, Fukasawa M, Nishijima M. Molecular machinery for non-vesicular trafficking of ceramide. Nature. 2003;426(6968):803-9.

Handman E. Leishmaniasis: current status of vaccine development. Clin Microbiol Rev. 2001;14(2):22943. 
Handman E, Kedzierski L, Uboldi AD, Goding JW. Fishing for anti-leishmania drugs: principles and problems. Adv Exp Med Biol. 2008;625:48-60.

Hannun YA, Obeid LM. Principles of bioactive lipid signalling: lessons from sphingolipids. Nat Rev Mol Cell Biol. 2008;9(2):139-50.

Harper MJ, Walpole AL. Contrasting endocrine activities of cis and trans isomers in a series of substituted triphenylethylenes. Nature. 1996;212(5057):87.

Harvey JM, Clark GM, Osborne CK, Allred DC. Estrogen receptor status by immunohistochemistry is superior to the ligand-binding assay for predicting response to adjuvant endocrine therapy in breast cancer. J Clin Oncol. 1999;17(5):1474-81.

Hernandez Y, Shpak M, Duarte TT, Mendez TL, Maldonado RA, Roychowdhury S, Rodrigues ML, Das S. Novel role of sphingolipid synthesis genes in regulating giardial encystation. Infect Immun. 2008;76(7):2939-49.

Herwaldt B. Leishmaniasis. Lancet. 1999;354:1191-9.

Hiraoka M, Abe A, Shayman JA. Cloning and characterization of a lysosomal phospholipase A2, 1-0acylceramide synthase. J Biol Chem. 2002;277(12):10090-9.

Hotez P, Ferris M. The antipoverty vaccines. Vaccine. 2006;24:5787-99.

Hotez P. The Giant Anteater in the Room: Brazil's Neglected Tropical Diseases Problem. PLoS Negl Trop Dis. 2008;2(1):e177.

Hotez P, Fenwick A, Savioli L, Molyneux DH. Rescuing the bottom billion through control of neglected tropical diseases. Lancet. 2009;373:1570-5.

Hsu FF, Turk J, Zhang K, Beverley SM. Characterization of inositol phosphorylceramides from Leishmania major by tandem mass spectrometry with electrospray ionization. J Am Soc Mass Spectrom. 2007;18(9):1591-604.

Ichikawa S, Nakajo N, Sakiyama H, Hirabayashi Y. A mouse B16 melanoma mutant deficient in glycolipids. Proc Natl Acad Sci U S A. 1994;91(7):2703-7. 
Iraji F, Sadeghinia A. Efficacy of paromomycin ointment in the treatment of cutaneous leishmaniasis: results of a double-blind, randomized trial in Isfahan, Iran. Ann Trop Med Parasitol. 2005;99(1):3-9.

Jordan VC. Antiestrogens and selective estrogen receptor modulators as multifunctional medicines. J Med Chem. 2003;46(6):883-908.

Jordan VC. New insights into the metabolism of tamoxifen and its role in the treatment and prevention of breast cancer. Steroids. 2007;72(13):829-42.

Jordan VC. Tamoxifen: catalyst for the change to targeted therapy. Eur J Cancer. 2008;44(1):30-8.

Kahl LP, McMahon-Pratt D. Structural and antigenic characterization of a species- and promastigotespecific Leishmania mexicana amazonensis membrane protein. J Immunol. 1987;138(5):1587-95.

Kalil SP. Caracterização funcional das proteínas LRR17 em Leishmania (Leishmania) major. [dissertação (Mestrado em Ciências)]. São Paulo (Brasil): Instituto de Ciências Biomédicas da Universidade de São Paulo; 2010.

Kayser O, Kiderlen AF, Bertels S, Siems K. Antileishmanial activities of aphidicolin and its semisynthetic derivatives. Antimicrob Agents Chemother. 2001;45(1):288-92.

Kaneshiro ES, Jayasimhulu K, Lester RL. Characterization of inositol lipids from Leishmania donovani promastigotes: identification of an inositol sphingophospholipid. J Lipid Res. 1986;27(12):1294-303.

Kedzierski L, Zhu Y, Handman E. Leishmania vaccines: progress and problems. Parasitology. 2006;133 (Suppl):S87-112.

Kedzierski L, Sakthianandeswaren A, Curtis JM, Andrews PC, Junk PC, Kedzierska K. Leishmaniasis: current treatment and prospects for new drugs and vaccines. Curr Med Chem. 2009;16(5):599-614.

Kovács P, Pintér M, Csaba G. Effect of glucosphingolipid synthesis inhibitor (PPMP and PDMP) treatment on Tetrahymena pyriformis: data on the evolution of the signaling system. Cell Biochem Funct. 2000;18(4):269-80.

Laemmli UK. Cleavage of structural proteins during the assembly of the head of bacteriophage T4. Nature. 1970;227(5259):680-5. 
Lainson R, Shaw JJ. Evolution, classification and geographical distibution. In: Peters W, Killick-Kendrick $\mathrm{R}$, editors. The leishmaniasis in Biology and Medicine. London: Academic Press; 1987. p. 1-120.

Lainson R, Rangel EF. Lutzomyia longipalpis and the eco-epidemiology of American visceral leishmaniasis, with particular reference to Brazil: a review. Mem Inst Oswaldo Cruz. 2005;100:811-82.

Landfear SM. Drugs and transporters in kinetoplastid protozoa. Adv Exp Med Biol. 2008;625:22-32.

Landoni M, Duschak VG, Erra-Balsells R, Couto AS. UV-MALDI mass spectrometry analysis of NBDglycosphingolipids without an external matrix. J Am Soc Mass Spectrom. 2008;19(7):923-6.

Lapa e Silva JR. Doenças Negligenciadas: Doenças Micobacterianas. Gaz méd Bahia. 2008;78(Supl. 1):80-5.

Lauer SA, Chatterjee S, Haldar K. Uptake and hydrolysis of sphingomyelin analogues in Plasmodium falciparum-infected red cells. Mol Biochem Parasitol. 2001;115(2):275-81.

Lavie Y, Cao H, Volner A, Lucci A, Han TY, Geffen V, Giuliano AE, Cabot MC. Agents that reverse multidrug resistance, tamoxifen, verapamil, and cyclosporin A, block glycosphingolipid metabolism by inhibiting ceramide glycosylation in human cancer cells. J Biol Chem. 1997;272(3):1682-7.

Lester RL, Dickson RC. Sphingolipids with inositolphosphate-containing head groups. Adv Lipid Res. 1993;26:253-74.

Liu B, Liu Y, Motyka AS, Agbo EE, Englund PT. Fellowship of the rings: the replication of kinetoplast DNA. Trends Parasitol. 2005;21(8):363-8.

Lightburn E, Morand JJ, Meynard JB, Kraemer P, Chaudier B, Pages F, Garnotel E, Patte JH, Banzet S, Dampierre H, Lepage J, Morillon M, Boutin JP, Hovette P, Chouc C. Management of American cutaneous leishmaniasis. Outcome apropos of 326 cases treated with high-dose pentamidine isethionate. Med Trop (Mars). 2003;63(1):35-44.

Lima HC, Bleyenberg JA, Titus RG. A simple method for quantifying Leishmania in tissues of infected animals. Parasitol Today. 1997;13(2):80-2. 
Lima TM, Amarante-Mendes GP, Curi R. Docosahexaenoic acid enhances the toxic effect of imatinib on Bcr-Abl expressing HL-60 cells. Toxicol In Vitro. 2007;21(8):1678-85.

Lipsky NG, Pagano RE. Intracellular translocation of fluorescent sphingolipids in cultured fibroblasts: endogenously synthesized sphingomyelin and glucocerebroside analogues pass through the Golgi apparatus en route to the plasma membrane. J Cell Biol. 1985;100(1):27-34.

Lira R, Sundar S, Makharia A, Kenney R, Gam A, Saraiva, Sacks D. Evidence that the high incidence of treatment failure in kala-azar is due to the emergence of antimony resistant strains of Leshmania donovani. J Infect Dis. 1999;180:564-7.

Lloyd-Smith JO, Poss M, Grenfell BT. HIV-1/parasite co-infection and the emergence of new parasite strains. Parasitology. 2008;135(7):795-806.

Loo SA, Lesoon-Wood LA, Cooney RV. Effects of tamoxifen on nitric oxide synthesis and neoplastic transformation in C3H 10T1/2 fibroblasts. Cancer Lett. 1998;122(1-2):67-75.

Lopez-Lluch G, Barroso MP, Martin SF, Fernandez-Ayala DJ, Gomez-Diaz C, Villalba JM, Navas P. Role of plasma membrane coenzyme $Q$ on the regulation of apoptosis. Biofactors. 1999;(2-4):171-7.

Löw P, Dallner G, Mayor S, Cohen S, Chait BT, Menon AK. The mevalonate pathway in the bloodstream form of Trypanosoma brucei. Identification of dolichols containing 11 and 12 isoprene residues. J Biol Chem. 1991;266(29):19250-7.

Luxo C, Jurado AS, Madeira VM, Silva MT. Tamoxifen induces ultrastructural alterations in membranes of Bacillus stearothermophilus. Toxicol In Vitro. 2003;17(5-6):623-8.

Maceyka M, Machamer CE. Ceramide accumulation uncovers a cycling pathway for the cis-Golgi network marker, infectious bronchitis virus M protein. J Cell Biol. 1997;139(6):1411-8.

Machado CM, Martins TC, Colturato I, Leite MS, Simione AJ, Souza MP, Mauad MS, Colturato VR. Epidemiology of neglected tropical diseases in transplant recipients. Review of the literature and experience of a Brazilian HSCT Center. Rev Inst Med Trop Sao Paulo. 2009;51(6):309-24.

Machado PR, Ampuero J, Guimarães LH, Villasboas L, Rocha AT, Schriefer A, Sousa RS, Talhari A, Penna $\mathrm{G}$, Carvalho EM. Miltefosine in the treatment of cutaneous leishmaniasis caused by Leishmania braziliensis in Brazil: a randomized and controlled trial. PLoS NegI Trop Dis. 2010;4(12):e912. 
Makino A, Ishii K, Murate M, Hayakawa T, Suzuki Y, Suzuki M, Ito K, Fujisawa T, Matsuo H, Ishitsuka R, Kobayashi T. D-threo-1-phenyl-2-decanoylamino-3-morpholino-1-propanol alters cellular cholesterol homeostasis by modulating the endosome lipid domains. Biochemistry. 2006;45(14):4530-41.

Mandlekar S, Kong AN. Mechanisms of tamoxifen-induced apoptosis. Apoptosis. 2001;(6):469-77. Marsden PD. Mucocutaneous leishmaniasis. BMJ. 1990;301(6753): 656-7.

Mauricio IL, Stothard JR, Miles MA. The strange case of Leishmania chagasi. Parasitol Today. 2000; 16(5):188-9.

Merril Jr, Sandhoff K. Sphingolipids: Metabolism and cell signaling. In: Vance De, Vance JE, editors. Biochemistry of Lipids, Lipoproteins and Membranes. $4^{\text {th }}$ ed. Amsterdam: Elsevier; 2006. p. 373-406.

Mina JG, Mosely JA, Ali HZ, Shams-Eldin H, Schwarz RT, Steel PG, Denny PW. A plate-based assay system for analyses and screening of the Leishmania major inositol phosphorylceramide synthase. Int J Biochem Cell Biol. 2010;42(9):1553-61.

Mina JG, Mosely JA, Ali HZ, Denny PW, Steel PG. Exploring Leishmania major inositol phosphorylceramide synthase (LmjIPCS): insights into the ceramide binding domain. Org Biomol Chem. 2011;9(6):1823-30.

Miranda-Verástegui C, Llanos-Cuentas A, Arévalo I, Ward BJ, Matlashewski G. Randomized, doubleblind clinical trial of topical imiquimod $5 \%$ with parenteral meglumine antimoniate in the treatment of cutaneous leishmaniasis in Peru. Clin Infect Dis. 2005;40(10):1395-403.

Miziorko HM. Enzymes of the mevalonate pathway of isoprenoid biosynthesis. Arch Biochem Biophys. 2011;505(2):131-43.

Modabber F, Buffet PA, Torreele E, Milon G, Croft SL. Consultative meeting to develop a strategy for treatment of cutaneous leishmaniasis. Institute Pasteur, Paris. 13-15 June, 2006. Kinetoplastid Biol Dis. 2007;6:3.

Moosa-Kazemi SH, Yaghoobi-Ershadir MR, Akhavan AA, Abdoli H, Zahraei-Ramazani AR, Jafari R, Houshmand B, Nadim A, Hosseini M. Deltamethrin-impregnated bed nets and curtains in an anthroponotic cutaneous leishmaniasis control program in northeastern Iran. Ann Saudi Med. 2007;27(1):6-12.

Moreira ME, Del Portillo HA, Milder RV, Balanco JM, Barcinski MA. Heat shock induction of apoptosis in promastigotes of the unicellular organism Leishmania (Leishmania) amazonensis. 
J Cell Physiol. 1996;167(2):305-13.

Morel CM, Acharya T, Broun D, Dangi A, Elias C, Ganguly NK, Gardner CA, Gupta RK, Haycock J, Heher $A D$, Hotez PJ, Kettler HE, Keusch GT, Krattiger AF, Kreutz FT, Lall S, Lee K, Mahoney R, Martinez-Palomo A, Mashelkar RA, Matlin SA, Mzimba M, Oehler J, Ridley RG, Senanayake P, Singer P, Yun M. Health innovation networks to help developing countries address neglected diseases. Science. 2005;309:4014.

Morello KC, Wurz GT, DeGregorio MW. SERMs: current status and future trends. Crit Rev Oncol Hematol. 2002;43(1):63-76.

Motta JOC, Sampaio RNR. A pilot study comparing low-dose liposomal amphotericin B with N-methyl glucamine for the treatment of American cutaneous leishmaniasis. J Eur Acad Dermatol Venereol. 2011. In Press.

Muchmore DB. Raloxifene: A selective estrogen receptor modulator (SERM) with multiple target system effects. Oncologist. 2000;5(5):388-92.

Mukkada AJ, Meade JC, Glaser TA, Bonventre PF. Enhanced metabolism of Leishmania donovani amastigotes at acid pH: an adaptation for intracellular growth. Science. 1985;229:1099-101.

Murray HW. Clinical and experimental advances in treatment of visceral leishmaniasis. Antimicrob Agents Chemother. 2001;45(8):2185-97.

Murray HW, Berman JD, Davies CR, Saravia NG. Advances in leishmaniasis. Lancet. 2005;366:1561-77.

Murta SM, Romanha AJ. In vivo selection of a population of Trypanosoma cruzi and clones resistant to benznidazole. Parasitology. 1998;116:165-71.

Nascimento ET, Moura ML, Queiroz JW, Barroso AW, Araujo AF, Rego EF, Wilson ME, Pearson RD, Jeronimo SM. The emergence of concurrent HIV-1/AIDS and visceral leishmaniasis in Northeast Brazil. Trans R Soc Trop Med Hyg. 2011. In Press.

Navas P, Fernadez-Ayala DM, Martin SF, Lopez-Lluch G, De Caboa R, Rodriguez-Aguilera JC, Villalba JM. Ceramide-dependent caspase 3 activation is prevented by coenzyme $Q$ from plasma membrane in serum-deprived cells. Free Radic Res. 2002;36(4):369-74.

Neumann A, Baginski M, Czub J. How do sterols determine the antifungal activity of amphotericin B? Free energy of binding between the drug and its membrane targets. J Am Chem Soc. 2010; 29;132(51):18266-72. 
Ogretmen B, Hannun YA. Biologically active sphingolipids in cancer pathogenesis and treatment. Nat Rev Cancer. 2004;4(8):604-16.

Oliveira MC, Amorim RF, Freitas RA, Costa LA. A fatal case of mucocutaneous leishmaniasis after pentavalent antimonial use. Rev Soc Bras Med Trop. 2005;38(3):258-60.

Olivier M, Gregory DJ, Forget G. Subversion mechanisms by which Leishmania parasites can escape the host immune response: a signaling point of view. Clin Microbiol Rev. 2005;18(2):293-305.

Pan American Health Organization (PAHO). PAHO/WHO, 2007 - Health in the Americas, vol I, Regional. Available from: http://www.paho.org/hia/index.html [2011 Mar 21].

Pandey BD, Pun SB, Kaneko O, Pandey K, Hirayama K. Case report: Expansion of visceral leishmaniasis to the western hilly part of Nepal. Am J Trop Med Hyg. 2011;84(1):107-8.

Papucci L, Schiavone N, Witort E, Donnini M, Lapucci A, Tempestini A, Formigli L, Zecchi-Orlandini S, Orlandini G, Carella G, Brancato R, Capaccioli S. Coenzyme q10 prevents apoptosis by inhibiting mitochondrial depolarization independently of its free radical scavenging property. J Biol Chem. 2003;278(30):28220-8.

Park WC, Jordan VC. Selective estrogen receptor modulators (SERMS) and their roles in breast cancer prevention. Trends Mol Med. 2002;8(2):82-8.

Pattingre S, Bauvy C, Levade T, Levine B, Codogno P. Ceramide-induced autophagy: to junk or to protect cells? Autophagy. 2009;5(4):558-60.

Pérez-Victoria FJ, Castanys S, Gamarro F. Leishmania donovani resistance to miltefosine involves a defective inward translocation of the drug. Antimicrob Agents Chemother. 2003;47(8):2397-403.

Picado A, Singh SP, Rijal S, Sundar S, Ostyn B, Chappuis F, Uranw S, Gidwani K, Khanal B, Rai M, Paudel IS, Das ML, Kumar R, Srivastava P, Dujardin JC, Vanlerberghe V, Andersen EW, Davies CR, Boelaert M. Longlasting insecticidal nets for prevention of Leishmania donovani infection in India and Nepal: paired cluster randomised trial. BMJ. 2010;341:c6760.

Radin NS, Shayman JA, Inokuchi J. Metabolic effects of inhibiting glucosylceramide synthesis with PDMP and other substances. Adv Lipid Res. 1993;26:183-213. 
Rasmussen JA, Hermetter A. Chemical synthesis of fluorescent glycero- and sphingolipids. Prog Lipid Res. 2008;47(6):436-60.

Rey L. Parasitologia: parasitos e doenças parasitárias do homem nos trópicos ocidentais. 4a ed. Rio de Janeiro: Guanabara Koogan; 2008.

Roberts LS, Janovy JJr. Gerald D. Schmidt \& Larry S. Roberts' Foundations of Parasitology. $6^{\text {th }}$ ed. New York: McGraw-Hill; 2000.

Rouanet P, Linares-Cruz G, Dravet F, Poujol S, Gourgou S, Simony-Lafontaine J, Grenier J, Kramar A, Girault J, Le Nestour E, Maudelonde T. Neoadjuvant percutaneous 4-hydroxytamoxifen decreases breast tumoral cell proliferation: a prospective controlled randomized study comparing three doses of 4-hydroxytamoxifen gel to oral tamoxifen. J Clin Oncol. 2005;23(13):2980-7.

Sacks D, Kamhawi S. Molecular aspects of parasite-vector and vector-host interactions in leishmaniasis. Annu Rev Microbiol. 2001;55:453-83.

Santa Cruz AR, Medrano EE, Baldi A. Dolichol-sugar derivative synthesis in human breast cancer cell line (T47D). Effects of estrogens and antiestrogens. Biochem Biophys Res Commun. 1985;126(1):382-8.

Santos MA, Marques RC, Farias CA, Vasconcelos DM, Stewart JM, Costa DL, Costa CH. Predictors of an unsatisfactory response to pentavalent antimony in the treatment of American visceral leishmaniasis. Rev Soc Bras Med Trop. 2002;35(6):629-33.

Schmelz EM, Dombrink-Kurtzman MA, Roberts PC, Kozutsumi Y, Kawasaki T, Merrill AH Jr. Induction of apoptosis by fumonisin B1 in HT29 cells is mediated by the accumulation of endogenous free sphingoid bases. Toxicol Appl Pharmacol. 1998;148(2):252-60.

Serapovic D, Kelekar A, Nayak AK, Tarca AL, Hanada K, Pierce JS, Bielawski J. Increased ceramide accumulation correlates with downregulation of the autophagy protein ATG-7 in MCF-7 cells sensitized to photodamage. Arch Biochem Biophys. 2010;494(1):101-5.

Sereno D, Holzmuller P, Mangot I, Cuny G, Ouaissi A, Lemesre JL. Antimonial-mediated DNA fragmentation in Leishmania infantum amastigotes. Antimicrob Agents Chemother. 2001;45(7):2064-9.

Sharief AH, Gasim Khalil EA, Theander TG, Kharazmi A, Omer SA, Ibrahim ME. Leishmania donovani: an in vitro study of antimony-resistant amphotericin B-sensitive isolates. Exp Parasitol. 2006;114(4):24752.

Shayman JA. Sphingolipids. Kidney Int. 2000;58(1):11-26. 
Silva LHP, Nussenzweig V. Sobre uma cepa de Trypanosoma cruzi altamente virulenta para o camundongo branco. Folia Clin Biol. 1953;20:191-207.

Singh S, Sivakumar R. Challenges and new discoveries in the treatment of leishmaniasis. J Infect Chemother. 2004;10(6):307-15.

Sonda S, Stefanic S, Hehl AB. A sphingolipid inhibitor induces a cytokinesis arrest and blocks stage differentiation in Giardia lamblia. Antimicrob Agents Chemother. 2008;52(2):563-9.

Soong L, Chang CH, Sun J, Longley BJ, Ruddle NH, Flavell RA, McMahon-Pratt D. Role of CD4+ T cells in pathogenesis associated with Leishmania amazonensis infection. J Immunol. 1997;158:5374-83.

Soto J, Arana BA, Toledo J, Rizzo N, Vega JC, Diaz A, Luz M, Gutierrez P, Arboleda M, Berman JD, Junge $\mathrm{K}$, Engel J, Sindermann H. Miltefosine for new world cutaneous leishmaniasis. Clin Infect Dis. 2004;38(9):1266-72.

Soto-Mancipe J, Grogl M, Berman JD. Evaluation of pentamidine for the treatment of cutaneous leishmaniasis in Colombia. Clin Infect Dis. 1993;16(3):417-25.

Straus AH, Valero VB, Takizawa CM, Levery SB, Toledo MS, Suzuki E, Salyan ME, Hakomori S, Barbieri $\mathrm{CL}$, Takahashi HK. Glycosphingolipid antigens from Leishmania (L.) amazonensis amastigotes. Binding of anti-glycosphingolipid monoclonal antibodies in vitro and in vivo. Braz J Med Biol Res. 1997;30(3):395-9.

Stuart K, Brun R, Croft S, Fairlamb A, Gürtler RE, McKerrow J, Reed S, Tarleton R. Kinetoplastids: related protozoan pathogens, different diseases. J Clin Invest. 2008;118(4):1301-10.

Sundar S, Rosenkaimer F, Makharia MK, Goyal AK, Mandal AK, Voss A, Hilgard P, Murray HW. Trial of oral miltefosine for visceral leishmaniasis. Lancet. 1998;352(9143):1821-3.

Sundar S. Drug resistance in Indian visceral leishmaniasis. Trop Med Int Health. 2001;6:849-54.

Sundar S, Chakravarty J, Agarwal D, Rai M, Murray HW. Single-dose liposomal amphotericin B for visceral leishmaniasis in India. N Engl J Med. 2010;362(6):504-12. 
Suzuki E, Tanaka AK, Toledo MS, Levery SB, Straus AH, Takahashi HK. Trypanosomatid and fungal glycolipids and sphingolipids as infectivity factors and potential targets for development of new therapeutic strategies. Biochim Biophys Acta. 2008;1780(3):362-9.

Tanaka AK, Valero VB, Takahashi HK, Straus AH. Inhibition of Leishmania (Leishmania) amazonensis growth and infectivity by aureobasidin A. J Antimicrob Chemother. 2007;59(3):487-92.

Taras TL, Wurz GT, DeGregorio MW. In vitro and in vivo biologic effects of Ospemifene (FC-1271a) in breast cancer. J Steroid Biochem Mol Biol. 2001;77(4-5):271-9.

Tempone AG, Martins de Oliveira C, Berlinck RG. Current Approaches to Discover Marine Antileishmanial Natural Products. Planta Med. 2011. In Press.

Thakur CP, Kanyok TP, Pandey AK, Sinha GP, Zaniewski AE, Houlihan HH, Olliaro P. A prospective randomized, comparative, open-label trial of the safety and efficacy of paromomycin (aminosidine) plus sodium stibogluconate versus sodium stibogluconate alone for the treatment of visceral leishmaniasis. Trans R Soc Trop Med Hyg. 2000;94(4):429-31.

Thakur CP, Kumar M, Pandey AK. Comparison of regimes of treatment of antimony-resistant kala-azar patients: a randomized study. Am J Trop Med Hyg. 1991;45(4):435-41.

Tuon FF, Amato VS, Graf ME, Siqueira AM, Nicodemo AC, Amato Neto V. Treatment of New World cutaneous leishmaniasis--a systematic review with a meta-analysis. Int J Dermatol. 2008;47(2):109-24.

Uliana SR, Goyal N, Freymüller E, Smith DF. Leishmania: overexpression and comparative structural analysis of the stage-regulated meta 1 gene. Exp Parasitol. 1999;92(3):183-91.

van Griensven J, Balasegaram M, Meheus F, Alvar J, Lynen L, Boelaert M. Combination therapy for visceral leishmaniasis. Lancet Infect Dis. 2010;10(3):184-94.

Varki A. Biological roles of oligosaccharides: all of the theories are correct. Glycobiology.1993;3(2):97130.

Velozo D, Cabral A, Ribeiro MC, Motta JO, Costa IM, Sampaio RN. Leishmaniose mucosa fatal em criança. An Bras Dermatol. 2006;81(3):255-9.

Vioukov VN. Control of transmission. In: Peters W, Killick-Kendrick R, editors. The leishmaniasis in Biology and Medicine. London: Academic Press; 1987. p. 909-28. 
Wang E, Norred WP, Bacon CW, Riley RT, Merrill AH Jr. Inhibition of sphingolipid biosynthesis by fumonisins. Implications for diseases associated with Fusarium moniliforme. J Biol Chem. 1991;266(22):14486-90.

Wang $\mathrm{H}$, Charles AG, Frankel AJ, Cabot MC. Increasing intracellular ceramide: an approach that enhances the cytotoxic response in prostate cancer cells. Urology. 2003;61(5):1047-52.

Wasunna MK, Rashid JR, Mbui J, Kirigi G, Kinoti D, Lodenyo H, Felton JM, Sabin AJ, Albert MJ, Horton J. A phase II dose-increasing study of sitamaquine for the treatment of visceral leishmaniasis in Kenya. Am J Trop Med Hyg. 2005;73(5):871-6.

Wiseman H, Cannon M, Arnstein HR, Halliwell B. Mechanism of inhibition of lipid peroxidation by tamoxifen and 4-hydroxytamoxifen introduced into liposomes. Similarity to cholesterol and ergosterol. FEBS Lett. 1990;274(1-2):107-10.

Wiseman H, Smith C, Arnstein HR, Halliwell B, Cannon M. The antioxidant action of ketoconazole and related azoles: comparison with tamoxifen and cholesterol. Chem Biol Interact. 1991;79(2):229-43.

Wiseman H, Cannon M, Arnstein HR, Barlow DJ. The structural mimicry of membrane sterols by tamoxifen: evidence from cholesterol coefficients and molecular-modelling for its action as a membrane anti-oxidant and an anti-cancer agent. Biochim Biophys Acta. 1992;1138(3):197-202.

Werneck GL, Batista MS, Gomes JR, Costa DL, Costa CH. Prognostic factors for death from visceral leishmaniasis in Teresina, Brazil. Infection. 2003;31(3):174-7.

World Health Organization (WHO). WHO, 2010 - First WHO Report on Neglected Tropical Diseases. Available from: http://www.who.int/neglected diseases/2010report/en/index.html [2011 Mar 21].

World Health Organization (WHO). 2011. Leishmaniasis and HIV Coinfection. Available from: http://www.who.int/leishmaniasis/burden/hiv coinfection/burden hiv coinfection/en/index.html [2011 Apr 05].

Wortmann G, Zapor M, Ressner R, Fraser S, Hartzell J, Pierson J, Weintrob A, Magill A. Lipsosomal amphotericin B for treatment of cutaneous leishmaniasis. Am J Trop Med Hyg. 2010;83(5):1028-33.

Yardley V, Ortuno N, Llanos-Cuentas A, Chappuis F, Doncker SD, Ramirez L, Croft S, Arevalo J, Adaui V, Bermudez H, Decuypere S, Dujardin JC. American tegumentary leishmaniasis: Is antimonial treatment outcome related to parasite drug susceptibility? J Infect Dis. 2006;194(8):1168-75. 
Zamboni DS, Rabinovitch M. Nitric oxide partially controls Coxiella burnetii phase II infection in mouse primary macrophages. Infect Immun. 2003;71(3):1225-33.

Zauli-Nascimento RC, Miguel DC, Yokoyama-Yasunaka JK, Pereira LI, Pelli de Oliveira MA, Ribeiro-Dias F, Dorta ML, Uliana SR. In vitro sensitivity of Leishmania (Viannia) braziliensis and Leishmania (Leishmania) amazonensis Brazilian isolates to meglumine antimoniate and amphotericin B. Trop Med Int Health. 2010;15(1):68-76.

Zhang K, Showalter M, Revollo J, Hsu FF, Turk J, Beverley SM. Sphingolipids are essential for differentiation but not growth in Leishmania. EMBO J. 2003;22(22):6016-26.

Zhang K, Pompey JM, Hsu FF, Key P, Bandhuvula P, Saba JD, Turk J, Beverley SM. Redirection of sphingolipid metabolism toward de novo synthesis of ethanolamine in Leishmania. EMBO J. 2007;26(4):1094-104.

Zhang K, Beverley SM. Phospholipid and sphingolipid metabolism in Leishmania. Mol Biochem Parasitol. 2010;170(2):55-64.

Zhang O, Wilson MC, Xu W, Hsu FF, Turk J, Kuhlmann FM, Wang Y, Soong L, Key P, Beverley SM, Zhang K. Degradation of host sphingomyelin is essential for Leishmania virulence. PLoS Pathog. 2009;5(12):e1000692. 
ANEXO A - Tamoxifen is effective against Leishmania and induces a rapid alkalinization of parasitophorous vacuoles harbouring Leishmania (Leishmania) amazonensis amastigotes 


\title{
Tamoxifen is effective against Leishmania and induces a rapid alkalinization of parasitophorous vacuoles harbouring Leishmania (Leishmania) amazonensis amastigotes
}

\author{
Danilo C. Miguel ${ }^{1}$, Jenicer K. U. Yokoyama-Yasunaka ${ }^{1}$, Walter K. Andreoli ${ }^{2}$, Renato A. Mortara ${ }^{2}$ \\ and Silvia R. B. Uliana ${ }^{1 *}$ \\ ${ }^{I}$ Departamento de Parasitologia, Instituto de Ciências Biomédicas, Universidade de São Paulo, São Paulo \\ 05508-900 SP, Brazil; ${ }^{2}$ Departamento de Microbiologia, Imunologia e Parasitologia, Escola Paulista \\ de Medicina, Universidade Federal de São Paulo, São Paulo 04023-062 SP, Brazil
}

Received 8 February 2007; returned 6 April 2007; revised 7 May 2007; accepted 24 May 2007

\begin{abstract}
Objectives: This study was performed to investigate the activity of tamoxifen, an antioestrogen widely used in the treatment of breast cancer, against Leishmania.

Methods: Drug activity was assessed in vitro against axenically grown promastigotes and amastigotes through cell counting or by measuring the cleavage of MTT, and against intracellular amastigotes by treating infected macrophage cultures and evaluating the number of intracellular parasites. Intravacuolar $\mathrm{pH}$ changes induced inside parasitophorous vacuoles of Leishmania (Leishmania) amazonensis-infected macrophages were evaluated using the fluorescent probes SNAFL-calcein and Acridine Orange.

Results: Tamoxifen killed $L$. (L.) amazonensis promastigotes and amastigotes with $50 \%$ inhibitory concentrations $\left(\mathrm{IC}_{50}\right)$ of $16.4 \pm 0.2$ and $11.1 \pm 0.2 \mu \mathrm{M}$, respectively. The drug was also effective against Leishmania (Viannia) braziliensis, Leishmania (Leishmania) major, Leishmania (Leishmania) chagasi and Leishmania (Leishmania) donovani with $\mathrm{IC}_{50}$ values ranging from 9.0 to $20.2 \mu \mathrm{M}$. Tamoxifen induced a rapid and long-lasting alkalinization of the vacuolar environment. We also provide evidence that tamoxifen is more effective against promastigotes and amastigotes at $\mathrm{pH} 7.5$ when compared with cultures at $\mathrm{pH} 4.5$.
\end{abstract}

Conclusions: Tamoxifen effectively kills several Leishmania species and its activity against the parasite is increased by a modulation of the host cell intravacuolar $\mathrm{pH}$ induced by the drug.

Keywords: chemotherapy, pH, oestradiol, Acridine Orange, SNAFL-calcein

\section{Introduction}

Human leishmaniasis is an endemic disease in 88 countries distributed in tropical and subtropical regions of the world. Clinical manifestations of this parasitic illness vary from self-healing cutaneous ulcers to very aggressive and disfiguring cases of diffuse or mucocutaneous diseases or to the life-threatening visceral form. More than $90 \%$ of cutaneous leishmaniasis cases occur in Iran, Afghanistan, Syria, Saudi Arabia, Brazil and Peru. ${ }^{1}$ In Brazil, Leishmania (Viannia) braziliensis is the most common agent for cutaneous and mucocutaneous leishmaniasis, whereas Leishmania (Leishmania) amazonensis is the most important causative agent of the diffuse form of the disease. Chemotherapy of leishmaniasis relies mainly on the administration of pentavalent antimonials that are toxic and poorly tolerated, require daily injections and are becoming ineffective due to the proliferation of resistant parasites. ${ }^{2,3}$ Therefore, alternative drugs are in pressing need.

Leishmania life cycle consists of two distinct forms: promastigotes, flagellated extracellular parasites of the digestive tract of sand flies, and amastigotes, non-flagellated, non-motile stages that live inside parasitophorous vacuoles (PVs) in macrophages of mammalian hosts. The PV encloses a strongly hydrolytic, acid environment $-\mathrm{pH}$ around 5.0 - and the amastigote does not

*Corresponding author. Tel: +55-11-30917334; Fax: +55-11-30917417; E-mail: srbulian@icb.usp.br 


\section{Antileishmanial activity of tamoxifen}

attenuate this hostile milieu. ${ }^{4-6}$ Amastigotes have been shown to carry out vital processes (i.e. cellular respiration, nutrient uptake and DNA and RNA synthesis) under these conditions. ${ }^{7}$

Tamoxifen is a triphenylethylene widely used in the treatment and in the prevention of breast cancer due to its activity as an oestrogen receptor modulator. ${ }^{8}$ However, it has become evident that many biological effects of tamoxifen are independent of the oestrogen machinery, such as modulation of calmodulin, caspases and kinases, ${ }^{9}$ interference in ceramide metabolism, ${ }^{10,11}$ inhibition of the acidification of intracellular organelles $^{12-14}$ and partitioning into lipids where it exerts membrane fluidizing and antioxidant activities. ${ }^{15}$

While oestrogen receptor modulated responses have not been described in Leishmania, some of the effects observed with tumour cell lines suggested a potential activity of tamoxifen against these parasites. Particularly interesting to us were the findings of Altan et al. ${ }^{13}$ showing that adriamycin resistance in breast cancer cells was reversed by tamoxifen as a result of the redistribution of cellular adriamycin from acidic organelles to the nucleus. These authors established that tamoxifen was able to inhibit the acidification of organelles in several cell types in an oestrogen-independent way. Since Leishmania amastigotes are well adapted to survive in acidic PV, it seemed plausible to test the activity of tamoxifen against these parasites. In this paper, we describe the activity of tamoxifen against promastigotes and amastigotes of Leishmania in vitro. We also show that tamoxifen is able to modify the intravacuolar $\mathrm{pH}$ of $L$. (L.) amazonensis-infected macrophages inducing a state where the drug activity against the parasite is increased.

\section{Materials and methods}

\section{Cells}

Promastigotes of L. (L.) amazonensis (MHOM/BR/1973/M2269), L. (V.) braziliensis (MHOM/BR/1975/M2903), Leishmania (Leishmania) chagasi (MHOM/BR/1974/M2682), Leishmania (Leishmania) donovani (LD-15/MHOM/SD/00) and Leishmania (Leishmania) major (MHOM/IL/1981/Friedlin) were grown in Medium 199 (Invitrogen) supplemented with $10 \%$ or $20 \%$ heat-inactivated fetal calf serum (FCS; Invitrogen) and incubated at $25^{\circ} \mathrm{C}$. Liquid cultures of $L$. (V.) braziliensis and $L$. (L.) chagasi were also supplemented with $2 \%$ sterile male human urine. L. (L.) amazonensis amastigotes were obtained from experimentally infected $\mathrm{BALB} / \mathrm{c}$ mice as described previously. ${ }^{16}$ Amastigotes purified from lesions were kept at $33^{\circ} \mathrm{C}$ in RPMI 1640 medium (Invitrogen) supplemented with $10 \%$ FCS in an atmosphere of $5 \% \mathrm{CO}_{2}$. Parasites retained the typical amastigote morphology and were viable in these conditions for at least $48 \mathrm{~h}$.

Resident peritoneal macrophages were obtained by peritoneal lavage of 25- to 30-day-old female BALB/c mice with $3-5 \mathrm{~mL}$ of RPMI 1640 medium repeated three times. The collected cell suspension was centrifuged at $300 \mathrm{~g}$ for $10 \mathrm{~min}$ at $4^{\circ} \mathrm{C}$, the pellet was resuspended in RPMI 1640 medium supplemented with 10\% FCS and gentamicin $50 \mathrm{mg} / \mathrm{L}$ and cultivated at $37^{\circ} \mathrm{C}$ in an atmosphere of $5 \% \mathrm{CO}_{2}$.

The continuous line of human foreskin fibroblasts (HFF) was grown in RPMI 1640 supplemented with $10 \%$ FCS and cultivated at $37^{\circ} \mathrm{C}$ in an atmosphere of $5 \% \mathrm{CO}_{2}$.

\section{Drugs}

Tamoxifen, 17 $\beta$-oestradiol and amphotericin B were purchased from Sigma-Aldrich, St Louis, MO, USA. Stock solutions of tamoxifen and $17 \beta$-oestradiol were prepared in ethanol and amphotericin B stock was prepared in DMSO (5 mM final concentration). Tamoxifen and amphotericin B were stored at $-20^{\circ} \mathrm{C}$ and $17 \beta$-oestradiol at room temperature.

\section{In vitro antiproliferative activity assays}

Cell viability was evaluated in vitro by cultivating promastigotes $\left(5 \times 10^{6}\right)$ or amastigotes $\left(1 \times 10^{7}\right)$ in 199 medium or RPMI 1640 , respectively. Parasites were incubated in the presence of increasing concentrations of tamoxifen $(2.5-30 \mu \mathrm{M}$ ), amphotericin B (as a control drug, $0.05-0.30 \mu \mathrm{M}$ ) or $17 \beta$-oestradiol in 24-well culture dishes (Corning Life Sciences, Corning, NY, USA) for $24 \mathrm{~h}$. Quantification of viable cells was assessed either by cell counting or by measuring the cleavage of 3-(4,5-dimethylthiazol-2-yl)-2,5diphenyl tetrazolium bromide (MTT; Sigma-Aldrich) by metabolically active cells as described previously. ${ }^{17}$ In brief, cells were incubated in 3-( $N$-morpholino) propanesulfonic acid (MOPS)-buffered saline [30 mM MOPS ( $\mathrm{pH} 7.2), 116 \mathrm{mM} \mathrm{NaCl}, 5.4 \mathrm{mM} \mathrm{KCl}$, $0.8 \mathrm{mM} \mathrm{MgSO}$, $5.5 \mathrm{mM}$ D-glucose] containing MTT $5 \mathrm{mg} / \mathrm{mL}$ for $2 \mathrm{~h}$ (at $25^{\circ} \mathrm{C}$ for promastigotes and $33^{\circ} \mathrm{C}$ for amastigotes). MTT cleavage was assessed by using a multiwell scanning spectrophotometer (Labsystems; Multiskan EX) with a reference wavelength of $690 \mathrm{~nm}$ and a test wavelength of $595 \mathrm{~nm}$. Assays were performed in triplicate and results are expressed as the mean percentage reduction of parasite numbers compared with untreated control wells calculated for at least three independent experiments. The 50\% and $90 \%$ inhibitory concentrations $\left(\mathrm{IC}_{50}\right.$ and $\left.\mathrm{IC}_{90}\right)$ were determined from sigmoidal regression of the concentration-response curves using Scientific Graphing and Analysis Software ORIGIN 7.5.

Alternatively, cell viability and growth was analysed by incubating promastigotes $\left(5 \times 10^{6}\right)$ in the presence of increasing concentrations of tamoxifen for $24 \mathrm{~h}$; parasites were then washed in PBS $\left[10 \mathrm{mM} \mathrm{Na} 2 \mathrm{PO}_{4}, 1.76 \mathrm{mM} \mathrm{KH}_{2} \mathrm{PO}_{4}(\mathrm{pH} 7.4), 137 \mathrm{mM} \mathrm{NaCl}\right.$ and $2.7 \mathrm{mM} \mathrm{KCl}$ ] and grown in 199 medium for additional $24 \mathrm{~h}$ in the absence of drug. At the end of this period, cell density was determined by counting aliquots of the cultures in a haemocytometer.

In vitro cytotoxicity was evaluated by cultivating $5 \times 10^{5} \mathrm{HFF}$ in 24-well plates for $24 \mathrm{~h}$ in the presence of increasing concentrations of tamoxifen $(5-80 \mu \mathrm{M})$. Cell viability was assessed by the MTT assay as described above and results are expressed as percentage reduction in cell viability compared with untreated control cultures. The $50 \%$ cytotoxic concentration $\left(\mathrm{CC}_{50}\right)$ was determined as described above for $\mathrm{IC}_{50}$ values.

\section{Drug activity against intracellular amastigotes}

Killing of intracellular L. (L.) amazonensis amastigotes was assayed by analyses of the number of infected cells in macrophage monolayers. Peritoneal macrophages were plated on round glass coverslips inside the wells of 24-well culture dishes, at a density of $4 \times 10^{5}$ cells per coverslip, in RPMI 1640 supplemented with $10 \%$ FCS and gentamicin $50 \mathrm{mg} / \mathrm{L}$. After $2 \mathrm{~h}$ of incubation at $37^{\circ} \mathrm{C}$ in an atmosphere of $5 \% \mathrm{CO}_{2}, L$. (L.) amazonensis stationary-phase promastigotes (in a ratio of 7 parasites: 1 macrophage) or lesion-derived amastigotes (1:1) were added to the wells and the cultures were incubated at $33^{\circ} \mathrm{C}$ in a $5 \% \mathrm{CO}_{2}$ atmosphere. After $3 \mathrm{~h}$, parasites were removed by extensive washing with RPMI medium without FCS and infected cultures were treated with increasing concentrations of tamoxifen $(5-20 \mu \mathrm{M})$ or amphotericin B 


\section{Miguel et al.}

$(0.01-0.30 \mu \mathrm{M})$ for $48 \mathrm{~h}$ or with ammonium chloride $\left(\mathrm{NH}_{4} \mathrm{Cl}, 5\right.$ or $10 \mathrm{mM}$ ) for $24 \mathrm{~h}$. The monolayers were washed, fixed and stained with the Instant Prov kit (Newprov, Pinhais, Brazil). The percentage of infected macrophages was assessed by light microscopy observation by counting 100 cells in triplicate coverslips. IC $_{50}$ and $\mathrm{IC}_{90}$ were calculated from data obtained in three independent experiments.

\section{Intravacuolar $\mathrm{pH}$ alterations in response to tamoxifen}

Intracellular and intravacuolar $\mathrm{pH}$ were evaluated using two different fluorescent probes: SNAFL-calcein and Acridine Orange (AO) (Sigma-Aldrich).

Peritoneal BALB/c macrophages $\left(8 \times 10^{5}\right)$ were cultivated on $0.15 \mathrm{~mm}$ thick coverslips in Delta $\mathrm{T}$ dishes (Bioptechs, Butler, PA, USA) in RPMI 1640 medium at $37^{\circ} \mathrm{C}$ in a $5 \% \mathrm{CO}_{2}$ atmosphere. After $3 \mathrm{~h}$, amastigotes of $L$. (L.) amazonensis purified from mice lesions were used for in vitro macrophage infections. Infected cultures were kept at $33^{\circ} \mathrm{C}$ in a $5 \% \mathrm{CO}_{2}$ atmosphere and samples were treated with $10 \mu \mathrm{M}$ tamoxifen, ethanol $(0.25 \%)$ or left untreated. Cells were loaded with the $\mathrm{pH}$-sensitive ratiometric probe SNAFL-calcein (Molecular Probes). ${ }^{18}$ Experiments were performed as previously described. ${ }^{19}$ Lasersharp software version 3.2 TC was used for image acquisition and basic processing.

Peritoneal BALB/c macrophages, plated on round glass coverslips as described above, were infected with $L$. (L.) amazonensis amastigotes. Infected and uninfected cells were incubated in RPMI 1640 medium with or without drugs for the times indicated in the figure legends. Tamoxifen treatment was performed at $10 \mu \mathrm{M}$ for $30 \mathrm{~min}$. For time-lapse experiments, tamoxifen-treated cultures (30 min) were washed and incubated with RPMI without drug for $30 \mathrm{~min}, 4$ or $24 \mathrm{~h}$. $\mathrm{NH}_{4} \mathrm{Cl}$ was used at 5 or $10 \mathrm{mM}$ concentrations for $30 \mathrm{~min}, 4$ or $24 \mathrm{~h}$. Cells were then incubated with $10 \mu \mathrm{M}$ AO in PBS for $10 \mathrm{~min}$ at room temperature. Culture samples were immediately analysed using a Nikon-Microphot SX Fluorescence Microscope. ACT-1 Control Software was used for image acquisition.

\section{pH effect on parasite viability and tamoxifen activity}

L. (L.) amazonensis promastigotes $\left(5 \times 10^{6}\right)$ or freshly purified lesion-derived amastigotes $\left(1 \times 10^{7}\right)$ were incubated in RPMI medium pH 4.5 or 7.5 supplemented with $5 \%$ FCS for 4 or $24 \mathrm{~h}$ in the absence or in the presence of increasing concentrations of tamoxifen. Quantification of cell growth was evaluated by counting aliquots of the cultures in a haemocytometer.

\section{Results}

\section{Activity of tamoxifen against Leishmania in vitro}

Tamoxifen was tested for its effect on the viability of $L$. (L.) amazonensis promastigotes in vitro. Cell viability, evaluated through MTT cleavage, decreased as a function of drug concentration. After $24 \mathrm{~h}$ of incubation, the calculated $\mathrm{IC}_{50}$ against L. (L.) amazonensis was $16.4 \pm 0.2 \mu \mathrm{M}$ (Table 1). As a control, activity of amphotericin B against $L$. amazonensis promastigotes was calculated as being $0.15 \pm 0.06 \mu \mathrm{M}$, in agreement with previously published data. ${ }^{20}$ These results were confirmed by cell counting. The effect of tamoxifen was irreversible since parasites incubated with the drug and left in normal culture media for $24 \mathrm{~h}$ did not recover (data not shown).

The activity of tamoxifen against other Leishmania species was analysed by testing promastigotes of $L$. (V.) braziliensis and
Table 1. In vitro activity of tamoxifen against Leishmania spp.

\begin{tabular}{|c|c|c|c|}
\hline Parasites & $\mathrm{IC}_{50}(\mu \mathrm{M})^{\mathrm{a}}$ & CI $95 \%^{\mathrm{b}}$ & $\mathrm{IC}_{90}(\mu \mathrm{M})$ \\
\hline L. amazonensis ${ }^{\mathrm{c}}$ & $16.4 \pm 0.2$ & $16.32-16.48$ & 21.3 \\
\hline L. amazonensis ${ }^{\mathrm{d}}$ & $11.1 \pm 0.2$ & $11.02-11.18$ & 17.5 \\
\hline L. braziliensis ${ }^{\mathrm{c}}$ & $10.0 \pm 0.1$ & $9.96-10.04$ & 20.9 \\
\hline L. chagasi $^{\mathrm{c}}$ & $17.7 \pm 0.8$ & $17.39-18.01$ & 27.9 \\
\hline L. donovani ${ }^{\mathrm{c}}$ & $19.9 \pm 0.3$ & $19.78-20.02$ & 37.0 \\
\hline L. major ${ }^{\mathrm{c}}$ & $9.3 \pm 0.3$ & $9.18-9.42$ & 14.0 \\
\hline
\end{tabular}

${ }^{\mathrm{a}}$ Values are expressed as means $\pm \mathrm{SD}$ of three independent experiments. ${ }^{\mathrm{b}} 95 \%$ confidence interval.

${ }^{\mathrm{c}}$ Promastigotes.

${ }^{\mathrm{d}}$ Amastigotes.

L. (L.) major, aetiological agents of cutaneous leishmaniasis and L. (L.) chagasi and $L$. (L.) donovani, species that cause visceral leishmaniasis. A dose-related response was detected when promastigotes of all the species tested were incubated with increasing concentrations of tamoxifen. The sensitivity of different Leishmania species was uniform with $\mathrm{IC}_{50}$ values ranging from 9.0 to $20.2 \mu \mathrm{M}$ as depicted in Table 1 .

Viability of L. (L.) amazonensis amastigotes, obtained from lesions and axenically cultivated for $24 \mathrm{~h}$ at $33^{\circ} \mathrm{C}$, was also inhibited by tamoxifen at an $\mathrm{IC}_{50}$ of $11.1 \pm 0.2 \mu \mathrm{M}$ (Table 1 ).

Cytotoxicity assays were performed treating HFF cultures with increasing concentrations of tamoxifen, allowing the determination of a $\mathrm{CC}_{50}$ of $22.8 \pm 2.6 \mu \mathrm{M}$. Treatment of HFF or peritoneal macrophage cultures with $10 \mu \mathrm{M}$ tamoxifen for $24 \mathrm{~h}$ resulted in $100 \%$ and $85 \%$ survival, respectively.

\section{Effect of tamoxifen on intracellular amastigote survival}

The activity of the drug against the parasite in the intracellular environment was tested by treating peritoneal BALB/c macrophage cultures infected with $L$. (L.) amazonensis. The $\mathrm{IC}_{50}$ of tamoxifen against intracellular amastigotes was $5.46 \pm 0.12 \mu \mathrm{M}$ and the $\mathrm{IC}_{90}$ was calculated as $6.73 \mu \mathrm{M}$ (Figure 1 and data

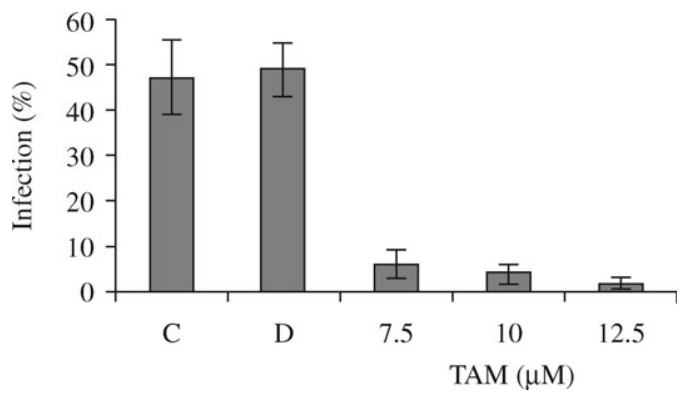

Figure 1. Activity of tamoxifen against intracellular L. (L.) amazonensis amastigotes in vitro. Macrophages were infected with L. (L.) amazonensis promastigotes for $3 \mathrm{~h}$ in a ratio of 7 parasites: 1 macrophage. After infection, cultures were incubated in the presence of tamoxifen at final concentrations of $7.5,10$ or $12.5 \mu \mathrm{M}$ for $48 \mathrm{~h}$. Cells were fixed and stained and the percentage of infection was determined by counting 100 cells/coverslip. Cultures were tested in triplicates and the results shown are representative of three independent experiments. Bars represent percentage of infected cells in: control untreated cultures (C), cells incubated with the drug diluent ethanol (D), or treated with tamoxifen. 


\section{Antileishmanial activity of tamoxifen}

not shown). Parasitism was unaltered in control-infected cells incubated in the presence of ethanol (the drug diluent). Testing of amphotericin B in the same assays allowed the calculation of an $\mathrm{IC}_{50}$ of $0.050 \pm 0.003 \mu \mathrm{M}$ for intracellular amastigotes.

\section{Oestradiol does not alter the viability of L. (L.) amazonensis promastigotes or the activity of tamoxifen}

A search for oestrogen receptor homologues in the $L$. (L.) major genome database did not produce positive hits, indicating that tamoxifen's activity on these parasites is unlikely to be linked to the oestrogen receptor. To verify whether this was indeed the case, L. (L.) amazonensis promastigotes were incubated with increasing concentrations of $17 \beta$-oestradiol and with equimolar concentrations of oestradiol plus tamoxifen. 17 $\beta$-Oestradioltreated parasites did not exhibit changes in growth or survival while parasites incubated with the combination of equimolar concentrations of $17 \beta$-oestradiol and tamoxifen were as sensitive to the drug as parasites incubated with tamoxifen alone (Figure 2). The same was observed for lesion-derived $L$. (L.) amazonensis amastigotes which exhibited the same pattern of growth in the absence or in the presence of $17 \beta$-oestradiol while incubation with $17 \beta$-oestradiol did not modify the activity of tamoxifen (Figure 2), confirming that the leishmanicidal activity of tamoxifen is independent of the oestrogen receptor machinery.

\section{Intravacuolar $\mathrm{pH}$ alterations in response to tamoxifen}

In vitro infections were analysed using non-invasive ratiometric confocal microscopy with dual-label SNAFL-calcein-AM probe before and after incubation with $10 \mu \mathrm{M}$ tamoxifen. SNAFL-calcein-AM compartmentalizes into acid vacuoles and the fluorescence is emitted in distinct wavelengths according to $\mathrm{H}^{+}$concentrations - the more acidic the intravacuolar $\mathrm{pH}$, the greener the organelle appears, whereas a more alkaline environment appear in tones towards red. As shown in Figure 3, images were obtained by merging the 550 and $640 \mathrm{~nm}$ emission channels. In infected and untreated macrophages, SNAFLcalcein-AM was detected mainly as yellow and green granules concentrated in the PV. Upon addition of tamoxifen and as incubation time elapsed, detection of SNAFL-calcein-AM in PVs was more intense in the $640 \mathrm{~nm}$ emission channel, resulting in red fluorescence (Figure 3). This suggested a rapid alkalinization of the PVs, detectable as soon as $10 \mathrm{~min}$ after drug addition. The presence of parasites inside PVs was confirmed by the phase contrast images also shown in Figure 4. Infected macrophages treated with $10 \mu \mathrm{M}$ tamoxifen for $24 \mathrm{~h}$ and incubated with SNAFL-calcein-AM exhibited large vacuoles devoid of amastigotes and more alkaline than PVs in untreated cells (data not shown).

Measurements of intravacuolar $\mathrm{pH}$ were also carried out in infected macrophages treated with ethanol in the concentration necessary to deliver the highest tamoxifen concentration used in the tests. Changes in $\mathrm{pH}$ were not observed in these cells (data not shown) indicating that the effect obtained with tamoxifen was not due to the drug diluent.

These findings were therefore consistent with the hypothesis of reduced acidification of intracellular compartments induced by tamoxifen, previously observed in other systems.

The effect of tamoxifen on intravacuolar acidification was also tested labelling peritoneal BALB/c macrophages infected with $L$. (L.) amazonensis amastigotes with $\mathrm{AO}$, a weakly basic

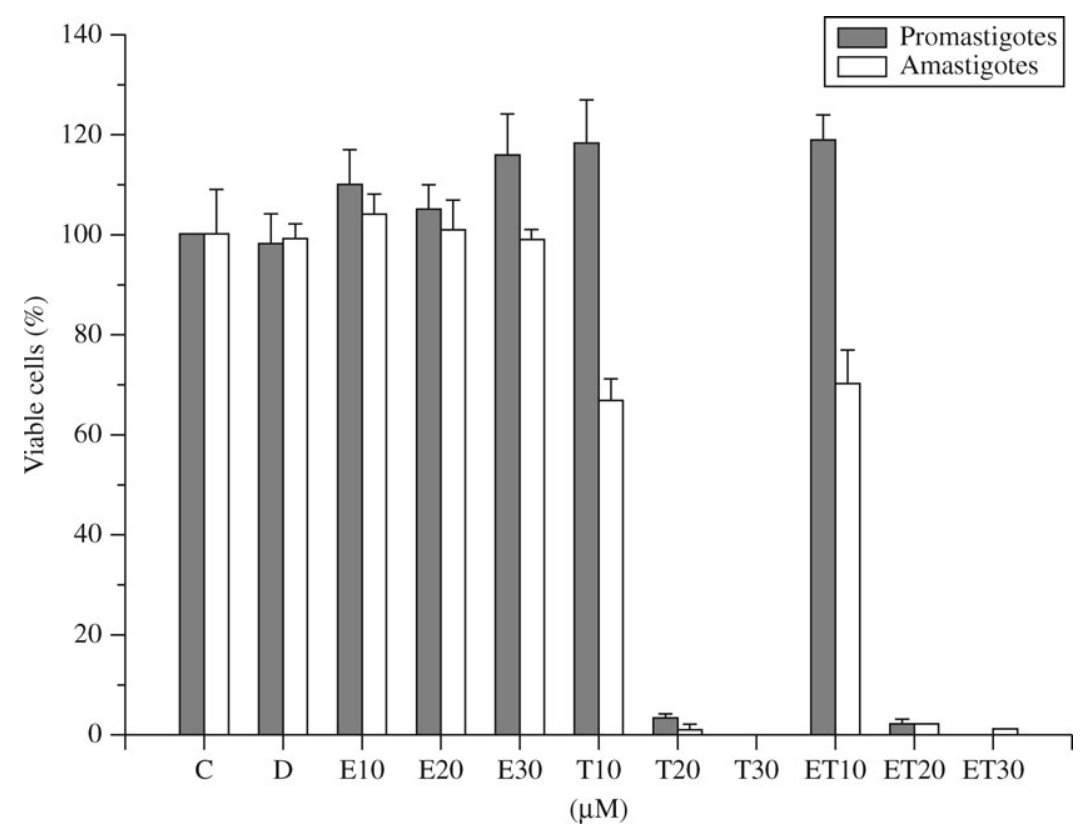

Figure 2. Effect of $17 \beta$-oestradiol, tamoxifen and $17 \beta$-oestradiol/tamoxifen on the survival of L. (L.) amazonensis promastigotes and amastigotes. Promastigotes (grey bars) or amastigotes (white bars) were incubated for $24 \mathrm{~h}$ with 10, 20 or $30 \mu \mathrm{M} 17 \beta$-oestradiol (E10, E20, E30), 10, 20 or 30 $\mu$ M tamoxifen (T10, T20, T30) or with the equimolar mixture of 17 $\beta$-oestradiol and tamoxifen (ET10, ET20, ET30). Viability was evaluated by MTT and calculated as a percentage of control parasites incubated without drugs (C). Control cultures were also incubated in the presence of the drug diluent ethanol (D). Cultures were tested in triplicate and the results shown are the average of two independent experiments. 


\section{Miguel et al.}
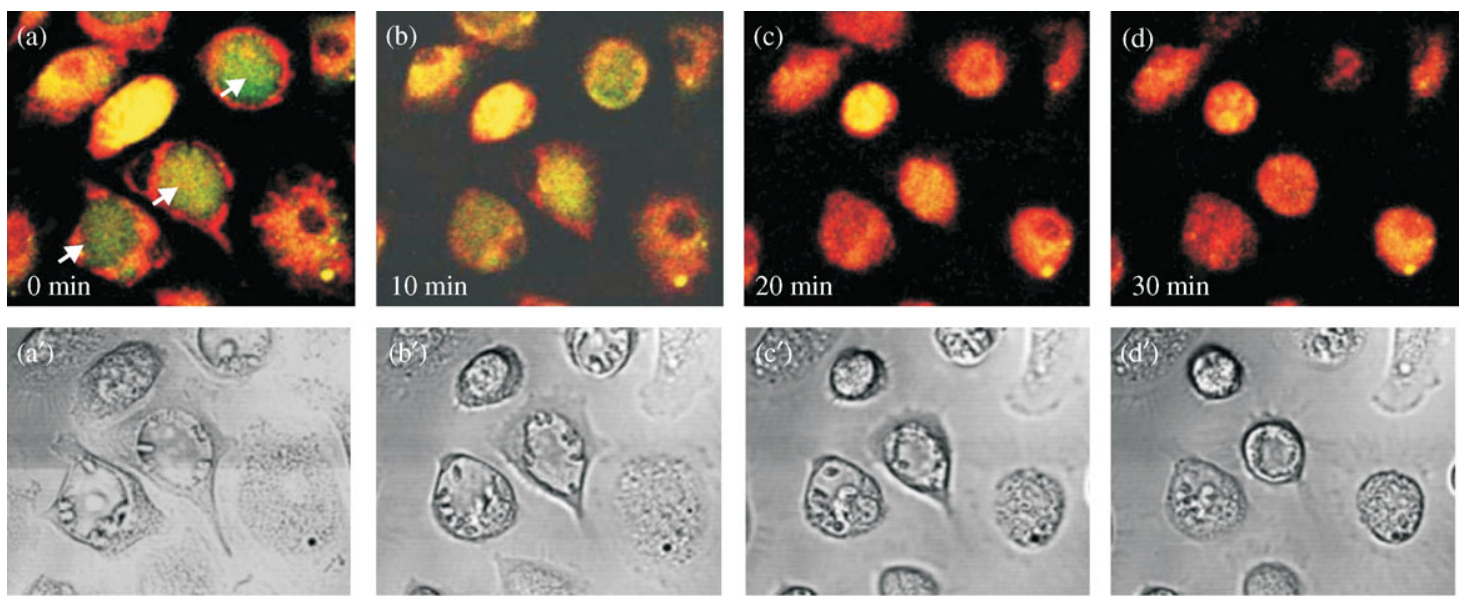

Figure 3. Confocal analysis of intravacuolar $\mathrm{pH}$ alteration in response to tamoxifen. $L$. (L.) amazonensis amastigote-infected macrophages were incubated with SNAFL-calcein-AM. All images were obtained by confocal microscopy $(63 \times 1.4)$ using a superposition of fluorescein $(550 \mathrm{~nm})$ and rhodamine $(640 \mathrm{~nm})$ emission channels $(\mathrm{a}-\mathrm{d})$ or by phase contrast $\left(\mathrm{a}^{\prime}-\mathrm{d}^{\prime}\right)$. After the initial acquiring of the image $(0 \mathrm{~min}), 10 \mu \mathrm{M}$ tamoxifen was added. The compartmentalization of SNAFL-calcein-AM into macrophages was monitored at 10, 20 and $30 \mathrm{~min}$. Arrows point to PV harbouring amastigotes.
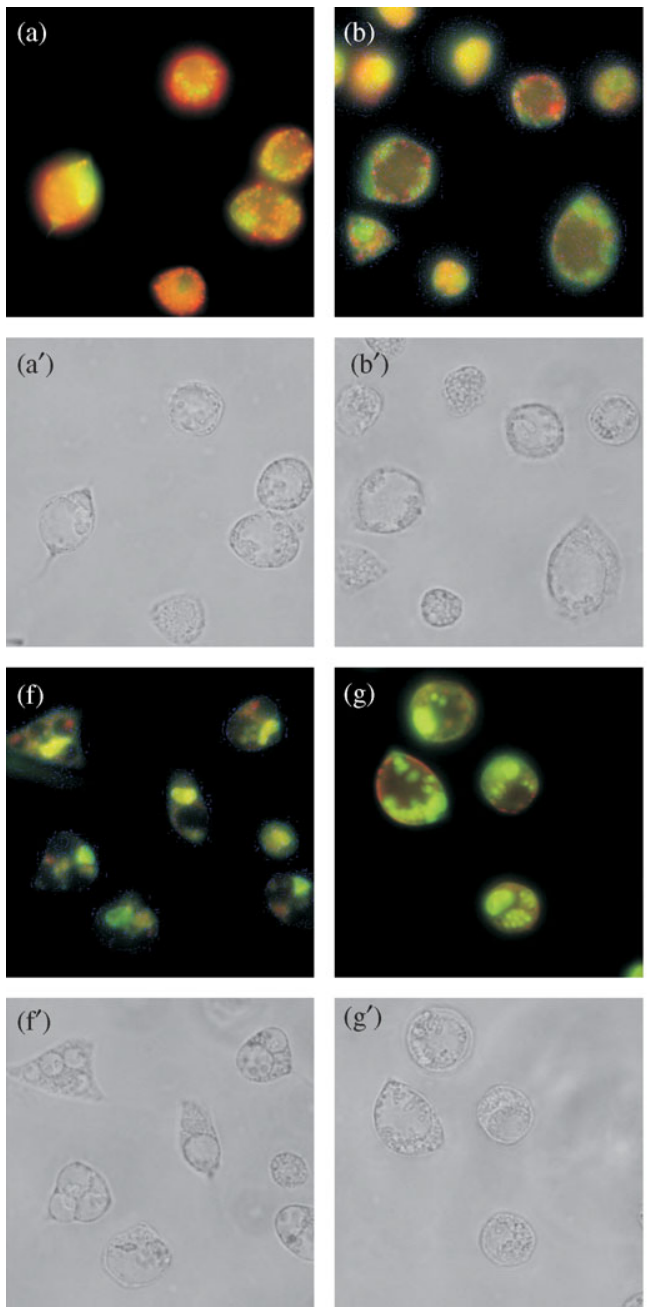
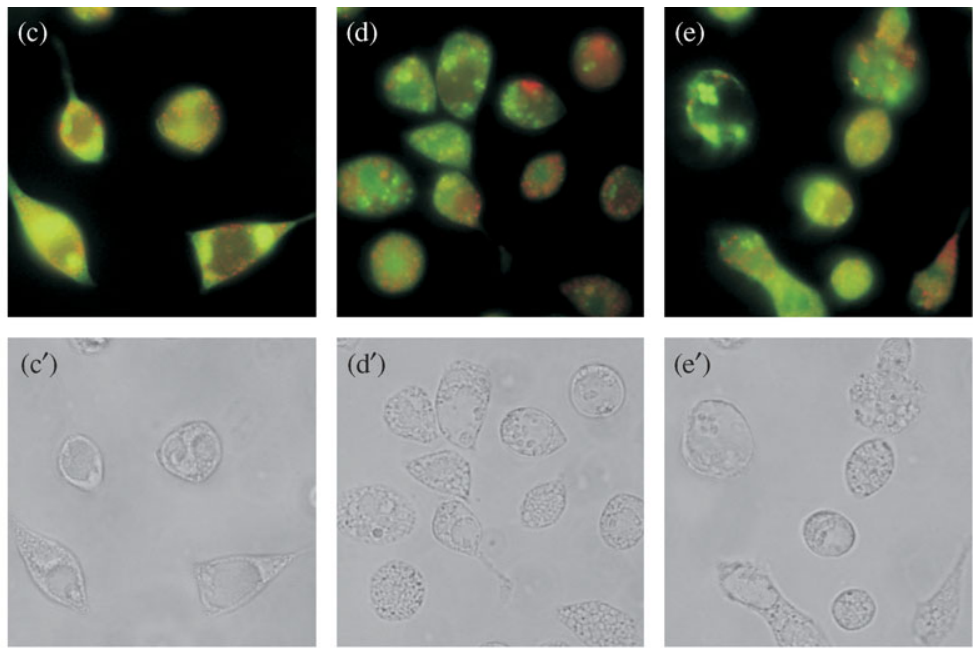
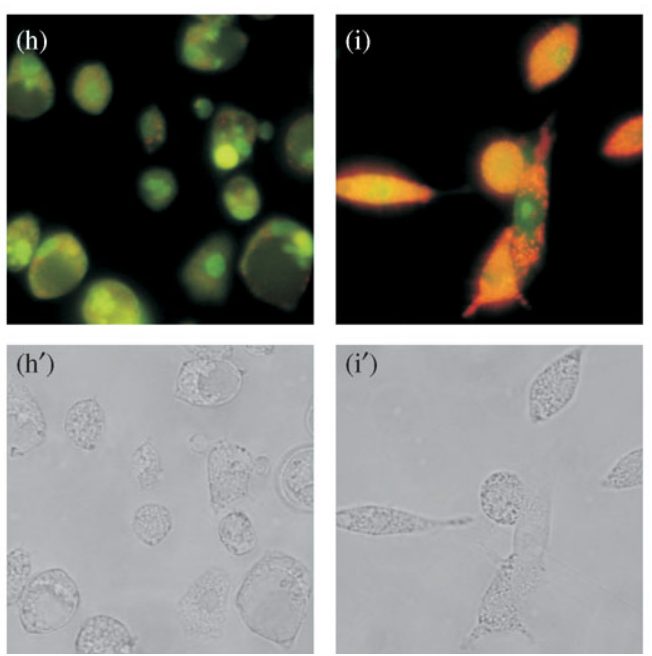

Figure 4. Analysis of $\mathrm{AO}$ accumulation in peritoneal macrophages upon treatment with tamoxifen or $\mathrm{NH}_{4} \mathrm{Cl}$. L. (L.) amazonensis-infected macrophages $(\mathrm{a}-\mathrm{h})$ or non-infected cells ( $\mathrm{i}$ and $\mathrm{j}$ ) were stained with AO after various treatments and fluorescence emissions of 530 and 640 nm acquired simultaneously: (a) untreated infected cells; (b) $10 \mu \mathrm{M}$ tamoxifen for $30 \mathrm{~min}$; (c), (d) and (e) $10 \mu \mathrm{M}$ tamoxifen for 30 min followed by washing and subsequent incubation in medium without drug for $30 \mathrm{~min}$ (c), $4 \mathrm{~h}$ (d) and $24 \mathrm{~h}$ (e); (f) $10 \mathrm{mM} \mathrm{NH} 4 \mathrm{Cl}$ for $30 \mathrm{~min}$; (g) $10 \mathrm{mM} \mathrm{NH}_{4} \mathrm{Cl}$ for 4 h; (h) $10 \mathrm{mM} \mathrm{NH} 4 \mathrm{Cl}$ for 24 h; (i) untreated uninfected macrophages; $(\mathrm{j})$ uninfected macrophages treated with $10 \mu \mathrm{M}$ tamoxifen for $30 \mathrm{~min}$. (a-j) Images acquired using fluorescence microscopy; ( $\mathrm{a}^{\prime}-\mathrm{j}^{\prime}$ ) respective phase contrast images. Magnification: $400 \times$. 


\section{Antileishmanial activity of tamoxifen}

fluorescent probe. AO is taken up by living cells and accumulates in acidic compartments. Fluorescence of $\mathrm{AO}$ is green at low concentrations, whereas at high concentrations the fluorescence changes to orange. ${ }^{21}$ Nuclei in infected or non-infected cells (Figure $4 \mathrm{a}$ and i) stained green. In the cytoplasm of infected cells, AO accumulated inside vacuoles containing amastigotes resulting in red fluorescence (Figure 4a). Upon addition of $10 \mu \mathrm{M}$ tamoxifen for $30 \mathrm{~min}$, a decrease of the red $\mathrm{AO}$ fluorescence was observed in PVs of infected cells (Figure 4b). To verify whether this effect was lasting, infected macrophages treated with tamoxifen for 30 min were washed and kept at $33^{\circ} \mathrm{C}$ for $30 \mathrm{~min}, 4$ or $24 \mathrm{~h}$ in culture media without drug (Figure $4 \mathrm{c}-\mathrm{e})$. Cells were then stained with $\mathrm{AO}$ for $10 \mathrm{~min}$ and examined. The $\mathrm{pH}$ in PVs of infected macrophages remained alkaline, even $24 \mathrm{~h}$ after drug removal, indicating that tamoxifen's effect on these cells was probably irreversible.

Tamoxifen's alkalinizing effect was not exclusive to infected cells, since non-infected macrophages also showed a remarkable reduction of orange-stained microvesicles (Figure $4 \mathrm{i}$ and $\mathrm{j}$ ).

\section{Alkalinization of the PV is not sufficient to control the infection}

To verify whether parasites were killed by tamoxifen's direct action or by an indirect effect of the drug on the host cell, two different approaches were taken. The alkalinizing agent $\mathrm{NH}_{4} \mathrm{Cl}$ was used to treat infected macrophages for $30 \mathrm{~min}, 4$ or $24 \mathrm{~h}$. As expected, 5 or $10 \mathrm{mM} \mathrm{NH} \mathrm{Nl}_{4} \mathrm{Cl}$ induced a $\mathrm{pH}$ shift observed in infected cells as AO stained PVs green (Figure $4 \mathrm{f}-\mathrm{h}$ and data not shown). However, the treatment of Leishmania-infected macrophages with 5 or $10 \mathrm{mM} \mathrm{NH} \mathrm{Nl}_{4}$ for $30 \mathrm{~min}$ or $24 \mathrm{~h}$ did not induce any reduction in the infection rates (Figure $4 \mathrm{f}-\mathrm{h}$ and Table 2), indicating that the alkaline PV is not sufficient to arrest the infection.

The second approach used to test whether tamoxifen's direct effect was required was to pre-treat uninfected macrophage cultures with tamoxifen for $24 \mathrm{~h}$. Cells were then washed, infected and the cultures were grown for additional $24 \mathrm{~h}$ in the absence of tamoxifen. Pre-treated macrophages were as permissive to the infection as naive cells and there was no reduction in the percentage of infection compared with control untreated cells (Table 2), indicating that tamoxifen is directly active against the intracellular parasite.

\section{Tamoxifen's activity is increased at neutral $\mathrm{pH}$}

To verify whether a neutral-alkaline $\mathrm{pH}$ in the PV would have any impact on drug activity, promastigotes and freshly lesionpurified amastigotes were submitted to tamoxifen treatment for 4 and $24 \mathrm{~h}$ at $\mathrm{pH} 4.5$ or 7.5 . A striking increase in drug activity was observed against promastigotes grown at $\mathrm{pH} 7.5$ as compared with cultures kept at $\mathrm{pH} 4.5$ (Figure 5a and b). A less pronounced but nonetheless clear increase in effect was also observed against amastigotes kept at neutral $\mathrm{pH}$ conditions (Figure $5 \mathrm{c}$ and $\mathrm{d}$ ). The increased parasite killing at neutral $\mathrm{pHs}$ was not due to the $\mathrm{pH}$ itself since, after 4 and $24 \mathrm{~h}$, both control promastigotes and amastigotes, grown in the absence of drugs, maintained unaltered their metabolic rate and viability in either $\mathrm{pH}$ as judged by similar optical densities in the MTT test (data not shown).
Table 2. Influence of PV alkalinization on parasitism

\begin{tabular}{lcc}
\hline & $\begin{array}{c}\text { Treatment with } \\
\mathrm{NH}_{4} \mathrm{Cl}^{\mathrm{a}}\end{array}$ & $\begin{array}{c}\text { Pre-treatment with } \\
\text { tamoxifen }^{\mathrm{b}}\end{array}$ \\
\hline Control & $100 \pm 0^{\mathrm{c}}$ & $92 \pm 4$ \\
$5 \mathrm{mM}(30 \mathrm{~min})$ & $98 \pm 1$ & - \\
$10 \mathrm{mM}(30 \mathrm{~min})$ & $100 \pm 0$ & - \\
$5 \mathrm{mM}(24 \mathrm{~h})$ & $98 \pm 2$ & - \\
$10 \mathrm{mM}(24 \mathrm{~h})$ & $97 \pm 2$ & $94 \pm 6$ \\
$5 \mu \mathrm{M}$ & - & $89 \pm 6$ \\
$7.5 \mu \mathrm{M}$ & - & $92 \pm 7$ \\
$10 \mu \mathrm{M}$ & - &
\end{tabular}

${ }^{\mathrm{a}}$ Infected cells were incubated with 5 or $10 \mathrm{mM} \mathrm{NH}_{4} \mathrm{Cl}$ for $30 \mathrm{~min}$ or $24 \mathrm{~h}$.

${ }^{\mathrm{b}}$ Prior to the infection, macrophages were incubated in medium with increasing concentrations of tamoxifen for $24 \mathrm{~h}$.

${ }^{c}$ All the values represent means \pm SD of the percentage of infected cells calculated from triplicate coverslips.

- , not determined.

This confirms that tamoxifen, with a $\mathrm{p} K_{\mathrm{a}}$ of 6.9 , is more effective in its neutral form, attained at neutral and alkaline pHs. Consequently, activity against intracellular amastigotes is probably intensified by the increase in $\mathrm{PV} \mathrm{pH}$ verified after addition of tamoxifen.

\section{Discussion}

We have shown that tamoxifen is effective against Leishmania. Susceptibility of microorganisms to tamoxifen in vitro has only been described for Candida albicans ${ }^{22}$ and Coccidioides immitis. ${ }^{23}$ There are, as yet, no reports available regarding the activity of tamoxifen against protozoan parasites.

The effect of tamoxifen against Leishmania is remarkable, given the absence of response to oestrogen in these organisms. On the other hand, several studies have reported biological properties of tamoxifen that cannot be explained by oestrogen receptor binding, such as the inhibition of acidification of organelles reported in tumour cells. ${ }^{14}$ Using resident peritoneal macrophages, we demonstrated that $10 \mu \mathrm{M}$ tamoxifen reduced parasitism by more than $90 \%$ in $24 \mathrm{~h}$. We have also shown that PVs of L. (L.) amazonensis-infected macrophages undergo a rapid $\mathrm{pH}$ shift upon addition of tamoxifen.

The rapid change in $\mathrm{PV} \mathrm{pH}$, however, is not directly responsible for killing amastigotes, as shown by the evaluation of parasite survival in $\mathrm{pH} 4.5$ or 7.5 . It does, however, have a major impact on tamoxifen's effectiveness against the parasite. That is most likely explained by the properties of tamoxifen: the neutral molecule partitions into the membrane and flips more easily into the interior than would the charged molecule. It is tempting to speculate that, once inside the acid PV, tamoxifen gets protonated, the $\mathrm{pH}$ shifts and this is followed by an increase in the influx of $\mathrm{Cl}^{-}$, as shown in microsomes isolated from MCF-7/ ADR cells. ${ }^{14}$ That would bring about the regeneration of neutral tamoxifen that may now combine with the amastigote membrane.

Besides the ability to accumulate in the lipid phase, tamoxifen has also been shown to be a potent inhibitor of ATPdependent membrane acid transport. ${ }^{24,25}$ Vacuoles containing 


\section{Miguel et al.}

(a)
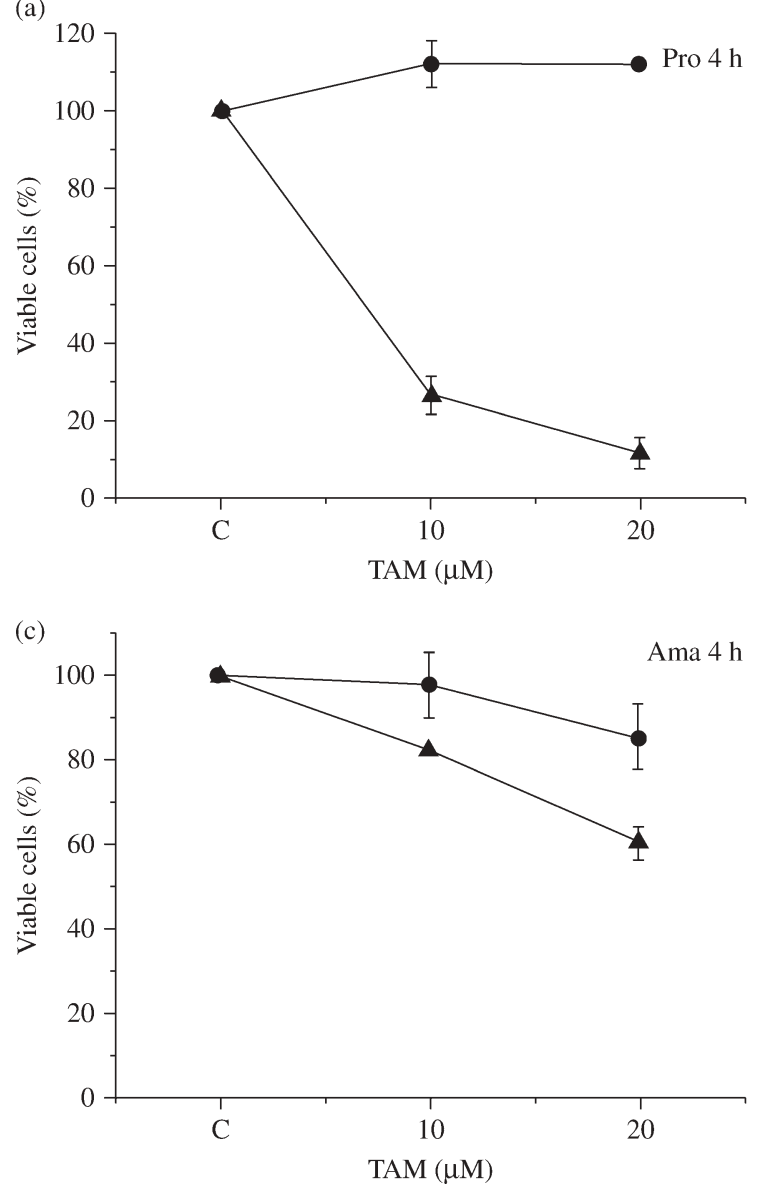

(b)
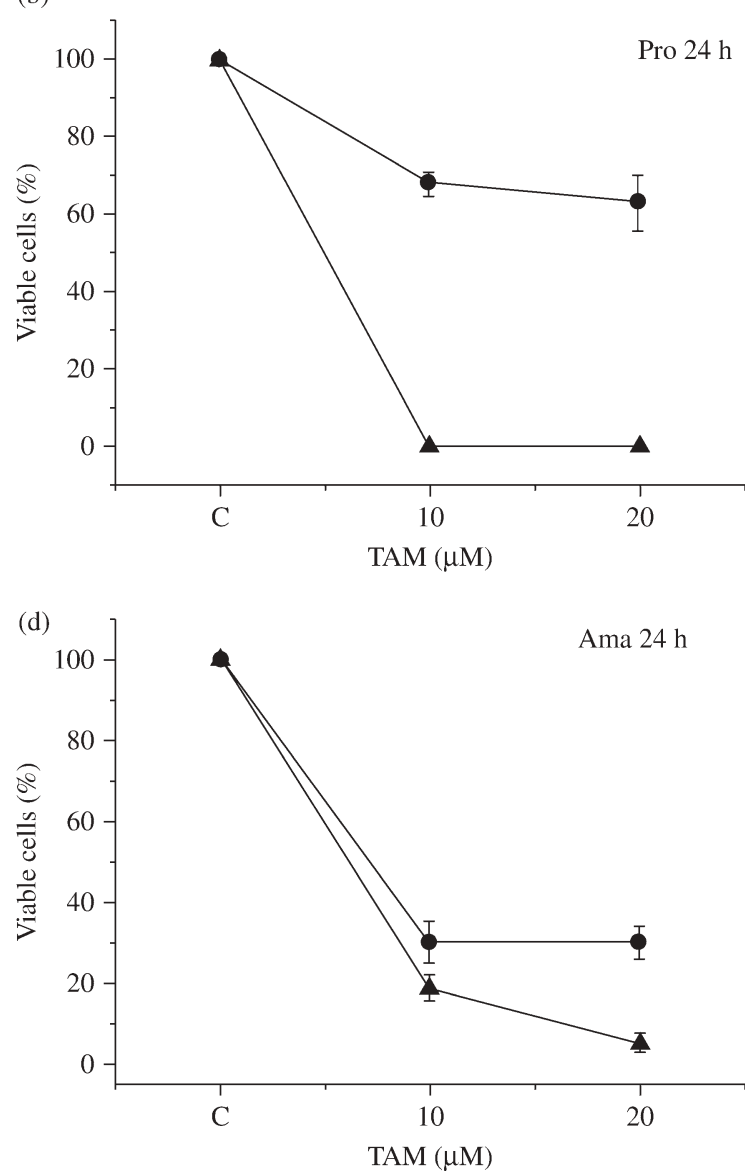

Figure 5. Effect of tamoxifen on the viability of L. (L.) amazonensis promastigotes (Pro) and amastigotes (Ama) at distinct pHs. Promastigotes (a and b) or amastigotes purified from lesions (c and d) were cultivated in RPMI medium with or without tamoxifen at densities of $1 \times 10^{7} /$ well at $\mathrm{pH} 4.5$ (filled circles) or 7.5 (filled triangles) for $4 \mathrm{~h}$ (a and c) or $24 \mathrm{~h}$ (b and d). The viability of parasites was evaluated after incubation with different concentrations of tamoxifen by counting aliquots of cultures in a haemocytometer. The survival of treated cultures is represented as a percentage of control parasites incubated without drug (C). Results represent the mean and standard deviation of cultures tested in triplicates.

Leishmania are rapidly acidified and reach $\mathrm{pH} 5.0$ in $<30 \mathrm{~min}$ after phagocytosis. ${ }^{26}$ The acidic luminal $\mathrm{pH}$ is sustained by a vacuolar $\mathrm{H}^{+}$-ATPase of macrophage origin in the PV membrane. Amastigotes also express a P-type $\mathrm{H}^{+}$-ATPase in their plasma membrane and may take part in the PV acidification. ${ }^{27}$ This P-type $\mathrm{H}^{+}$-ATPase is vital for the parasite to maintain a neutral internal $\mathrm{pH} .{ }^{28} \mathrm{H}^{+}$ATPases both at the PV membrane and at the amastigote surface could be the targets of tamoxifen's action resulting initially in vacuole alkalinization followed by disruption of the ionic metabolic steady-state of the parasite. Omeprazole, a potent ATPase inhibitor at acidic pHs, has been suggested as a potential antileishmanial drug. It has been shown to kill intracellular L. donovani in vitro through inhibition of the parasite $\mathrm{K}^{+}, \mathrm{H}^{+}$ATPase. ${ }^{29}$

Interestingly, not only intracellular amastigotes were killed by tamoxifen but also extracellular promastigotes. In fact, we showed that tamoxifen inhibits the survival of promastigotes of a wide range of Leishmania species, aetiological agents of distinct clinical forms of leishmaniasis, in a low micromolar concentration range. Plasma membrane P-type $\mathrm{H}^{+}$ATPases have also been shown to regulate intracellular $\mathrm{pH}$ in $L$. (L.) amazonensis promastigotes. ${ }^{30}$ Further studies are needed to verify whether tamoxifen's mechanism of action against Leishmania depends on ATPase inhibition.

Tamoxifen is highly lipophilic and has been shown to be strongly incorporated in biomembranes, reported to disrupt the structure of model and artificial membranes and to induce the permeabilization of mitochondria. ${ }^{31}$ It is also possible, therefore, that the effect on Leishmania is derived from drug partition into the parasite membranes. It has been observed that the partition of tamoxifen into membranes is modulated by several factors, including membrane composition: for example, partition of tamoxifen into membranes decreases as cholesterol concentration is raised. ${ }^{32}$ Leishmania do not synthesize cholesterol. Ergosterol makes up the main sterol in the plasma membrane in these parasites. ${ }^{33}$ Amastigotes have been shown to be able to incorporate cholesterol from their hosts but they are also able to synthesize ergosterol (D. C. Arruda and S. R. B. Uliana, unpublished results). Distinct parasite and host cell membrane compositions could result in preferential partitioning into the parasite's membrane. Further studies are necessary to verify whether tamoxifen is indeed incorporated into Leishmania membranes and if the presence of ergosterol favours the partition of tamoxifen. 


\section{Antileishmanial activity of tamoxifen}

Breast cancer accounts for $31 \%$ of all incident cancers in women in North America. It is estimated that more than 214000 new cases of breast cancer were diagnosed in the USA in $2005^{34}$ and tamoxifen represents the cornerstone of breast cancer treatment in women with tumours bearing hormone receptors. Since these patients are treated with tamoxifen for at least 5 years, much clinical experience has been gained on the safety and undesirable effects of the drug. Tamoxifen is well tolerated and side effects, of which the most serious is an increased risk for endometrial cancer, appear only after prolonged use. The doses usually administered for the treatment of breast cancer, of $20 \mathrm{mg} / \mathrm{kg}$ body weight, achieve serum concentrations of $0.2-$ $0.8 \mu \mathrm{M}^{35,36}$ Due to the high hydrophobicity of tamoxifen, in human tissues concentrations are 10- to 60-fold higher than in serum, with particularly high levels detected in the liver and lung. ${ }^{37}$ Tamoxifen also accumulates in the skin and bone tissue. ${ }^{37}$ This distribution pattern is relevant considering parasite localization in cutaneous and visceral leishmaniasis. Tissue concentrations attainable with currently used regimens are at least equivalent to the effective concentrations that kill Leishmania intracellular amastigotes in our study. Furthermore, it is to be expected that antileishmanial therapy with tamoxifen would not require such prolonged use. In conclusion, our results suggest that tamoxifen has a great potential to be tested as a therapeutic agent against leishmaniasis.

\section{Acknowledgements}

We are grateful to Dr Alejandro M. Katzin for providing tamoxifen for the initial experiments, and to Alexandre Santos de Moura, Dr A. Tania Bijovsky and Dr Maria Julia M. Alves for helping with the microscopy and for the critical reading of the manuscript.

\section{Funding}

This work was supported by Fundação de Amparo à Pesquisa do Estado de São Paulo (FAPESP). D. C. M. is the recipient of a post-graduate fellowship from FAPESP.

\section{Transparency declarations}

None to declare.

\section{References}

1. Special Programme for Research and Training in Tropical Diseases (TDR). http://www.who.int/tdr/diseases/leish/ (3 May 2007, date last accessed).

2. Croft SL, Coombs GH. Leishmaniasis: current chemotherapy and recent advances in the search for novel drugs. Trends Parasitol 2003; 19: 502-8.

3. Murray HW. Treatment of visceral leishmaniasis (kala-azar): a decade of progress and future approaches. Int $J$ Infect Dis 2000; 4: 158-77.

4. Burchmore RJS, Barret MP. Life in vacuoles-nutrient acquisition by Leishmania amastigotes. Int J Parasitol 2001; 31: 1311-20.
5. Rivas L, Chang KP. Intraparasitophorous vacuolar $\mathrm{pH}$ of Leishmania mexicana infected macrophages. Biol Bull 1983; 165: 536.

6. Antoine JC, Prina E, Jouanne $C$ et al. Parasitophorous vacuoles of Leishmania amazonensis-infected macrophages maintain an acidic pH. Infect Immun 1990; 58: 779-87.

7. Mukkada AJ, Meade JC, Glaser TA et al. Enhanced metabolism of Leishmania donovani amastigotes at acid $\mathrm{pH}$ : an adaptation for intracellular growth. Science 1985; 13: 1099-101.

8. Jordan VC. Tamoxifen: a most unlikely pioneering medicine. Nat Rev Drug Discov 2003; 2: 205-13.

9. Mandlekar S, Kong AN. Mechanisms of tamoxifen-induced apoptosis. Apoptosis 2001; 6: 469-77.

10. Lavie $\mathrm{Y}, \mathrm{Cao} \mathrm{H}$, Volner $\mathrm{A}$ et al. Agents that reverse multidrug resistance, tamoxifen, verapamil, and cyclosporin A, block glycosphingolipid metabolism by inhibiting ceramide glycosylation in human cancer cells. J Biol Chem 1997; 272: 1682-7.

11. Cabot MC, Giuliano AE, Volner $A$ et al. Tamoxifen retards glycosphingolipid metabolism in human cancer cells. FEBS Lett 1996; 394: 129-31.

12. Altan $N$, Chen $Y$, Schindler $M$ et al. Defective acidification in human breast tumor cells and implications for chemotherapy. $J$ Exp Med 1998; 187: 1583-98.

13. Altan $\mathrm{N}$, Chen $\mathrm{Y}$, Schindler $\mathrm{M}$ et al. Tamoxifen inhibits acidification in cells independent of the estrogen receptor. Proc Natl Acad Sci USA 1999; 96: 4432-7.

14. Chen $Y$, Schindler M, Simon SM. A mechanism for tamoxifenmediated inhibition of acidification. J Biol Chem 1999; 274: 18364-73.

15. Wiseman $\mathrm{H}$, Cannon M, Arnstein HR. The protective effect of ascorbate on the inhibition of growth, RNA and protein synthesis by tamoxifen in yeast is time dependent. Biochem Soc Trans 1990; 18: 1167-8.

16. Uliana SRB, Goyal N, Freymüller E et al. Leishmania: overexpression and comparative structural analysis of the stage-regulated meta 1 gene. Exp Parasitol 1999; 92: 183-91.

17. Barcinski MA, Schechtman D, Quintao LG et al. Granulocyte-macrophage colony-stimulating factor increases the infectivity of Leishmania amazonensis by protecting promastigotes from heat-induced death. Infect Immun 1992; 60: 3523-7.

18. Zhou Y, Marcus EM, Haugland RP et al. Use of a new fluorescent probe, seminaphthofluorescein-calcein, for determination of intracellular $\mathrm{pH}$ by simultaneous dual-emission imaging laser scanning confocal microscopy. J Cell Physiol 1995; 164: 9-16.

19. Andreoli WK, Mortara RA. Acidification modulates the traffic of Trypanosoma cruzi trypomastigotes in Vero cells harbouring Coxiella burnetii vacuoles. Int J Parasitol 2003; 33: 185-97.

20. Tanaka AK, Valero VB, Takahashi HK et al. Inhibition of Leishmania (Leishmania) amazonensis growth and infectivity by aureobasidin A. J Antimicrob Chemother 2007; 59: 487-92.

21. Barasch J, Kiss B, Prince A et al. Defective acidification of intracellular organelles in cystic fibrosis. Nature 1991; 352: 70-3.

22. Beggs $\mathrm{WH}$. Drug protonation and $\mathrm{pH}$ in relation to the lethal action of tamoxifen on Candida albicans. J Antimicrob Chemother 1996; 37: 841-2.

23. Drutz DJ, Huppert $\mathrm{M}$, Sun $\mathrm{SH}$ et al. Human sex hormones stimulate the growth and maturation of Coccidioides immitis. Infect Immun 1981; 32: 897-907.

24. Williams JP, McDonald JM, McKenna MA et al. Differential effects of tamoxifen-like compounds on osteoclastic bone degradation, $\mathrm{H}^{+}$-ATPase activity, calmodulin-dependent cyclic nucleotide phosphodiesterase activity, and calmodulin binding. J Cell Biochem 1997; 66: 358-69. 


\section{Miguel et al.}

25. Williams JP, Blair HC, McKenna MA et al. Regulation of avian osteoclastic $\mathrm{H}^{+}$-ATPase and bone resorption by tamoxifen and calmodulin antagonists. Effects independent of steroid receptors. J Biol Chem 1999; 271: 12488-95.

26. Sturgill-Koszycki S, Schlesinger $\mathrm{PH}$, Chakraborty $\mathrm{P}$ et al. Lack of acidification in Mycobacterium phagosomes produced by exclusion of the vesicular proton-ATPase. Science 1994; 263: 678-81.

27. Zilberstein $\mathrm{D}$, Shapira $\mathrm{M}$. The role of $\mathrm{pH}$ and temperature in the development of Leishmania parasites. Annu Rev Microbiol 1994; 48: 449-70.

28. Jiang $\mathrm{S}$, Anderson $\mathrm{SA}$, Winget GD et al. Plasma membrane $\mathrm{K}^{+}$/ $\mathrm{H}^{+}$-ATPase from Leishmania donovani. J Cell Physiol 1994; 159: 60-6.

29. Jiang S, Meadows J, Anderson SA et al. Antileishmanial activity of the antiulcer agent omeprazole. Antimicrob Agents Chemother 2002; 46: 2569-74.

30. Marchesini N, Docampo R. A plasma membrane P-type $\mathrm{H}^{+}$-ATPase regulates intracellular $\mathrm{pH}$ in Leishmania mexicana amazonensis. Mol Biochem Parasitol 2002; 119: 225-36.

31. Custódio JB, Moreno AJ, Wallace KB. Tamoxifen inhibits induction of the mitochondrial permeability transition by $\mathrm{Ca} 2+$ and inorganic phosphate. Toxicol Appl Pharmacol 1998; 152 : $10-7$.

32. Custódio JB, Almeida LM, Madeira VC. A reliable and rapid procedure to estimate drug partitioning in biomembranes. Biochem Biophys Res Commun 1991; 176: 1079-85.

33. Goad LJ, Holz GG, Jr, Beach DH. Sterols of Leishmania species. Implications for biosynthesis. Mol Biochem Parasitol 1984; 10: 161-70.

34. Jemal $A$, Siegel $\mathrm{R}$, Ward $\mathrm{E}$ et al. Cancer statistics, 2006. $C A$ Cancer J Clin 2006; 56: 106-30.

35. Kemp JV, Adam HK, Wakeling AE et al. Identification and biological activity of tamoxifen metabolites in human serum. Biochem Pharmacol 1983; 13: 2045-52.

36. Kisanga ER, Gjerde J, Guerrieri-Gonzaga A et al. Tamoxifen and metabolite concentrations in serum and breast cancer tissue during three dose regimens in a randomized preoperative trial. Clin Cancer Res 2004; 10: 2336-43.

37. Lien EA, Solheim E, Ueland PM. Distribution of tamoxifen and its metabolites in rat and human tissues during steady-state treatment. Cancer Res 1991; 51: 4837-44. 
ANEXO B - Tamoxifen as a potential antileishmanial agent: efficacy in the treatment of Leishmania braziliensis and Leishmania chagasi infections 


\title{
Tamoxifen as a potential antileishmanial agent: efficacy in the treatment of Leishmania braziliensis and Leishmania chagasi infections
}

\author{
Danilo C. Miguel ${ }^{1 \dagger}$, Rogéria C. Zauli-Nascimento ${ }^{1 \dagger}$, Jenicer K. U. Yokoyama-Yasunaka ${ }^{1}$, \\ Simone Katz ${ }^{2}$, Clara L. Barbiéri ${ }^{2}$ and Silvia R. B. Uliana ${ }^{1 *}$ \\ ${ }^{I}$ Department of Parasitology, Institute of Biomedical Sciences, Universidade de São Paulo, São Paulo, Brazil; \\ ${ }^{2}$ Department of Microbiology, Immunology and Parasitology, Universidade Federal de São Paulo, Escola Paulista \\ de Medicina, São Paulo, Brazil
}

Received 29 August 2008; returned 3 November 2008; revised 6 November 2008; accepted 23 November 2008

\begin{abstract}
Objectives: The aim of this study was to evaluate the efficacy of tamoxifen in vivo in experimental models of cutaneous (CL) and visceral leishmaniasis (VL) caused by Leishmania braziliensis and Leishmania chagasi, respectively.

Methods: Drug activity was assessed against intracellular amastigotes by treating infected macrophage cultures and evaluating the number of infected cells. In vivo efficacy of tamoxifen was tested in $L$. braziliensis-infected BALB/c mice and in L. chagasi-infected hamsters. Treatment with $20 \mathrm{mg} / \mathrm{kg} / \mathrm{day}$ tamoxifen was administered for $\mathbf{1 5}$ days by the intraperitoneal route. Efficacy was evaluated through measurements of lesion size, parasite burden at the lesion site or liver and spleen and survival rate.

Results: Tamoxifen killed $L$. braziliensis and $L$. chagasi intracellular amastigotes with $50 \%$ inhibitory concentrations $\left(\mathrm{IC}_{50}\right)$ of $1.9 \pm 0.2$ and $2.4 \pm 0.3 \mu \mathrm{M}$, respectively. Treatment of $L$. braziliensis-infected mice with tamoxifen resulted in significant reductions in lesion size and $99 \%$ decrease in parasite burden, compared with mock-treated controls. L. chagasi-infected hamsters treated with tamoxifen showed significant reductions in liver parasite load expressed as Leishman-Donovan units and $95 \%$ to $98 \%$ reduction in spleen parasite burden. All animals treated with tamoxifen survived while $100 \%$ of the mock-treated animals had died by 11 weeks after the interruption of treatment.
\end{abstract}

Conclusions: Tamoxifen is effective in the treatment of $\mathrm{CL}$ and $\mathrm{VL}$ in rodent models.

Keywords: chemotherapy, cutaneous leishmaniasis, visceral leishmaniasis, selective oestrogen receptor modulator, SERM

\section{Introduction}

Leishmania braziliensis is the most common causative agent of cutaneous leishmaniasis (CL) and mucocutaneous leishmaniasis in the New World and the main cause for the high annual incidence of the disease in Brazil. ${ }^{1}$ Visceral leishmaniasis (VL), caused by Leishmania chagasi in Latin America, is the most severe form of the disease and may lead to death if untreated. ${ }^{1}$

Leishmaniasis treatment is based on parenteral administration of highly toxic drugs, including pentavalent antimonials, amphotericin B and pentamidine. Resistance to antimonials is widespread in India and oral administration of miltefosine has emerged as an alternative approach, having been approved for management of $\mathrm{VL}^{2}$ Despite current reports validating miltefosine as a satisfactory chemotherapeutic compound in the treatment of L. braziliensis-infected patients in Bolivia, low effectiveness against $L$. braziliensis-infections has been reported in Guatemala. ${ }^{2}$ Therefore, the investigation of alternative leishmanicidal drugs remains imperative.

Tamoxifen, a classical oestrogen receptor antagonist in breast tissue, has been in clinical use for the treatment of breast cancer since $1971 .^{3}$ We have previously shown that tamoxifen is active

*Corresponding author. Tel: +55-11-30917334; Fax: +55-11-30917417; E-mail: srbulian@icb.usp.br

$\dagger$ Both authors contributed equally to this work. 


\section{Miguel et al.}

against several species of Leishmania in vitro. ${ }^{4}$ Recently, we have also demonstrated that treatment of L. amazonensis-infected $\mathrm{BALB} / \mathrm{c}$ mice with tamoxifen results in significant reductions in lesion and ulcer sizes, as well as in a sharp decrease in parasite burden. ${ }^{5}$

In this work, we have focused on the investigation of tamoxifen efficacy in the treatment of leishmaniasis using two distinct rodent models to mimic CL and VL caused by L. braziliensis and L. chagasi, respectively.

\section{Materials and methods}

The strains used were L. (Viannia) braziliensis (MHOM/BR/2001/ BA788) and L. (Leishmania) chagasi (MHOM/BR/1972/LD).

Drug cytotoxicity and activity against intracellular amastigotes were performed as described previously, ${ }^{4}$ except that BALB/c bone marrow-derived macrophages were used. Assays with the reference drug meglumine antimoniate (kindly donated by Sanofi-Aventis) were performed in parallel as described previously. ${ }^{6}$ Experiments were repeated at least three times.

In vivo experiments were approved by the Ethics Committee for Animal Experimentation. Female BALB/c mice $(n=6-8)$ were infected in the left ear with $1 \times 10^{5} \mathrm{~L}$. braziliensis promastigotes as described previously. ${ }^{7}$ Three weeks post-infection, groups were randomized according to the lesion size and $20 \mathrm{mg} / \mathrm{kg} / \mathrm{day}$ tamoxifen $(6 \mathrm{mg} / \mathrm{mL}$ tamoxifen citrate solutions in $150 \mathrm{mM} \mathrm{NaCl})$, $20 \mathrm{mg} / \mathrm{kg} /$ day meglumine antimoniate or sterile saline was administered by the intraperitoneal (ip) route for 15 days. Lesion size was recorded as the difference between infected and non-infected ear thickness. Parasite burden was determined 6 weeks after infection using the limiting dilution method. ${ }^{5}$ Body weight was recorded before and after treatment.

Golden hamsters (male or female, $n=6-12$ ) were infected with $1 \times 10^{8}$ L. chagasi amastigotes ip. Four weeks post-infection, animals were treated as described for $\mathrm{BALB} / \mathrm{c}$ mice. At the end of the treatment, parasite burden was determined in the liver as Leishman-Donovan units (LDU) and in the spleen by the limiting dilution assay. ${ }^{5}$ Parasite quantification was obtained for half of the animals in each group. The survival rate of the remaining animals was followed up for 3 months after the interruption of treatment. Serum concentrations of urea and creatinine were determined in hamsters at the end of treatment, using sets of commercial reagents (Doles Reagentes e Equipamentos para Laboratórios, Ltda., Brazil). Each in vivo experiment was repeated independently at least twice.

L. braziliensis and L. chagasi promastigotes differentiated from amastigotes recovered from treated animals were used to test drug sensitivity by determination of tamoxifen $\mathrm{IC}_{50}$ through cleavage of 3-(4,5-dimethylthiazol-2-yl)-2,5-diphenyl tetrazolium bromide (MTT) as previously described. ${ }^{4}$

Statistical analysis was performed using one-way ANOVA followed by Dunnett's post hoc test (GraphPad Prism, CA, USA). A $P$ value of $<0.05$ was considered statistically significant.

\section{Results}

Prior to the determination of tamoxifen activity against intracellular amastigotes, cytotoxicity assays were performed. The $\mathrm{IC}_{50}$ of tamoxifen for bone-marrow macrophages was higher than $20 \mu \mathrm{M}$. The treatment of L. braziliensis- or L. chagasi-infected macrophages with increasing concentrations of tamoxifen for $48 \mathrm{~h}$ allowed the determination of $\mathrm{IC}_{50} \mathrm{~s}$ for intracellular amastigotes (Table 1) and indicated that infection was completely abrogated with $9 \mu \mathrm{M}$ tamoxifen. The reference drug meglumine antimoniate was assayed in parallel with tamoxifen and $\mathrm{IC}_{50}$ values were within the expected range (Table 1).

L. braziliensis-infected $\mathrm{BALB} / \mathrm{c}$ mice were treated with saline, tamoxifen or meglumine antimoniate ip for 15 days. The treatment was initiated 3 weeks post-inoculation allowing the establishment of infection and development of lesions. At the end of the treatment, no statistically significant differences were detected in body weight between groups (tamoxifen, $22.6 \pm 0.7 \mathrm{~g} ;$ meglumine antimoniate, $23.9 \pm 1.6 \mathrm{~g}$; control, $23.3 \pm 2.0 \mathrm{~g})$.

Seven days after the end of treatment, all the animals that received saline showed erythema and swelling at the infection site. A significant decrease in the average lesion size was observed for tamoxifen and meglumine antimoniate-treated mice compared with mock-treated animals (Figure 1a). The average size of lesions at this timepoint was smaller in mice treated with tamoxifen than with meglumine antimoniate but this difference was not statistically significant.

Parasite burden in the lesion was evaluated at 6 weeks after inoculation of parasites (Figure 1b). Significant reductions of $99.0 \%$ and $99.9 \%$ were observed in tamoxifen- and meglumine antimoniate-treated mice, respectively (Figure 1b).

The treatment of L. chagasi-infected golden hamsters was initiated 4 weeks after infection. At the end of treatment, significant decreases in the liver (Figure 2a) and spleen (Figure 2b) parasite burden were detected in hamsters treated with tamoxifen compared with the control group. Tamoxifen was as effective as meglumine antimoniate with a $95 \%$ to $98 \%$ reduction in parasite load.

Table 1. In vitro activity of tamoxifen and meglumine antimoniate against Leishmania intracellular amastigotes

\begin{tabular}{|c|c|c|c|c|}
\hline & \multicolumn{2}{|c|}{ Tamoxifen $(\mu \mathrm{M})^{\mathrm{a}}$} & \multicolumn{2}{|c|}{ Meglumine antimoniate $(\mu \mathrm{g} / \mathrm{mL})^{\mathrm{b}}$} \\
\hline & $\mathrm{IC}_{50}(95 \% \mathrm{CI})$ & $\mathrm{IC}_{90}$ & $\mathrm{IC}_{50}(95 \% \mathrm{CI})$ & $\mathrm{IC}_{90}$ \\
\hline L. $(V)$. & $1.9 \pm 0.2(1.7-2.1)$ & 6.0 & $77.3 \pm 12.1(63.6-87.8)$ & 404.9 \\
\hline L. (L.) chagasi & $2.4 \pm 0.3(2.1-2.7)$ & 7.9 & $259.3 \pm 44.5(214.8-303.8)$ & 1024.7 \\
\hline
\end{tabular}

${ }^{\mathrm{a}}$ Values are expressed as means $\pm \mathrm{SD} ; 95 \%$ confidence intervals are shown in parentheses

${ }^{\mathrm{b}}$ Values are expressed as pentavalent antimony $\left[\mathrm{Sb}^{\mathrm{V}}\right]$. 


\section{Antileishmanial activity of tamoxifen}
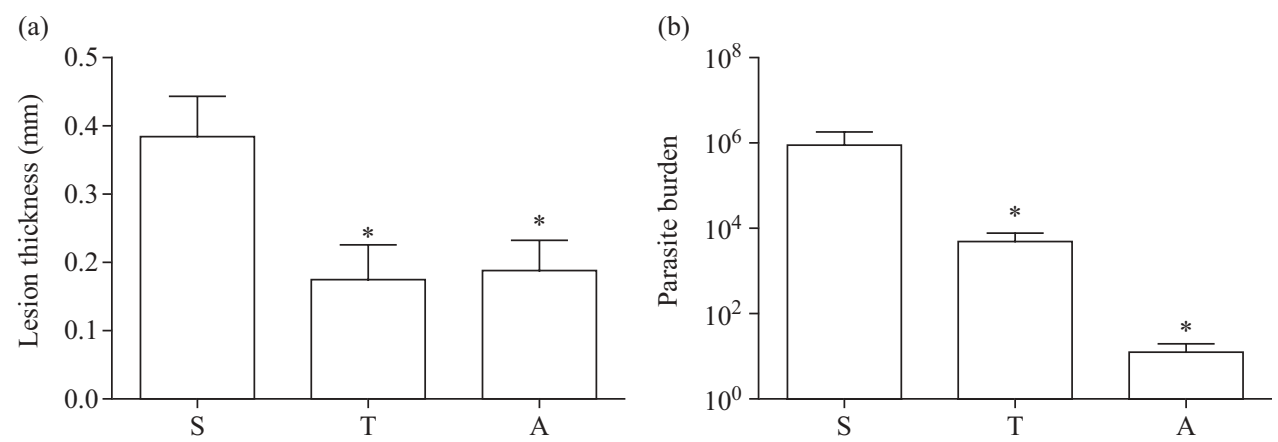

Figure 1. In vivo efficacy of tamoxifen in L. braziliensis infection. Female BALB/c mice were infected with L. braziliensis promastigotes in the left ear. Three weeks after infection, treatment was initiated with saline (S), $20 \mathrm{mg} / \mathrm{kg} / \mathrm{day}$ tamoxifen (T) or meglumine antimoniate (A) ip for 15 days. (a) Lesion thickness recorded 6 weeks after infection $(* P<0.05)$. (b) Parasite burden quantified by limiting dilution 7 days post-treatment $(* P<0.05)$. The results correspond to the mean of three independent experiments, each of them with $n=6$ per group.

(a)

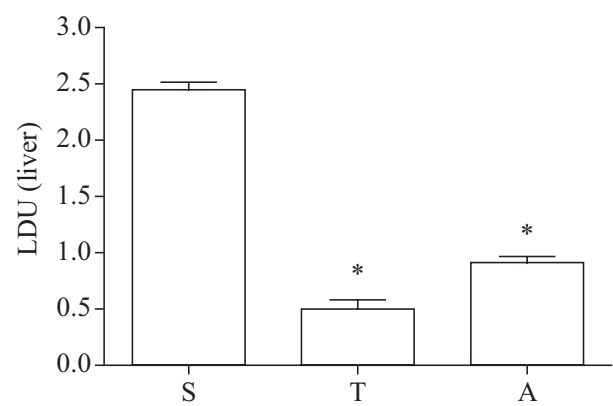

(b)

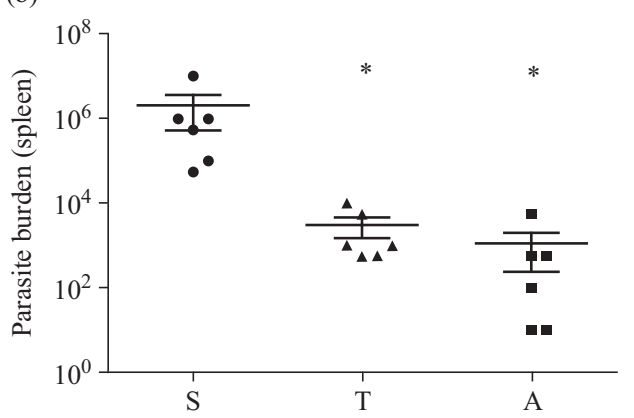

Figure 2. In vivo efficacy of tamoxifen in L. chagasi infection. Golden hamsters were infected with L. chagasi amastigotes. Four weeks post-infection, treatment was initiated with saline (S), $20 \mathrm{mg} / \mathrm{kg} /$ day tamoxifen (T) or meglumine antimoniate (A) ip for 15 days. (a) LDU measured by the number of amastigotes/cell $\times$ liver weight $(\mathrm{mg})(* P<0.0001)$. (b) Parasite burden quantified by limiting dilution at the end of the treatment $(7$ weeks post-infection) $\left({ }^{*} P<0.05\right)$. The results correspond to one of two independent experiments, $n=12$ per group.

To evaluate nephrotoxicity after treatment, serum levels of urea and creatinine were determined. No statistically significant alterations were detected between groups (data not shown). Additionally, at the end of treatment, the average body weight showed no significant variation between untreated $(138.7 \pm 12.4 \mathrm{~g})$, tamoxifen-treated $(127.8 \pm 9.3 \mathrm{~g})$ and meglumine antimoniate-treated animals $(139.4 \pm 15.9 \mathrm{~g})$.

After the interruption of treatment, the survival rate was also assessed. Death in saline-treated animals was detected from week 12 post-infection. By week 18, all control hamsters had died, while a $100 \%$ survival rate was registered in tamoxifen and meglumine antimoniate-treated groups.

Lastly, we investigated whether parasites recovered from tamoxifen-treated mice or hamsters presented reduced sensitivity to the drug. Tamoxifen $\mathrm{IC}_{50}$ values for L. braziliensis and L. chagasi promastigotes recovered from tamoxifen-treated animals were not different from those determined for parasites isolated from control mice $(17.7 \pm 0.4$ and $18.4 \pm 0.7 \mu \mathrm{M}$ for treated and control L. braziliensis and $16.1 \pm 1.9$ and $14.7 \pm 2.9 \mu \mathrm{M}$ for treated and control L. chagasi, respectively).

\section{Discussion}

Tamoxifen, a triphenylethylene derivative, has been shown to be cytotoxic to several neoplastic cell types. ${ }^{8}$ In vitro effects of tamoxifen have also been established for fungal cells ${ }^{9}$ and Leishmania parasites. ${ }^{4}$ Having demonstrated the in vitro activity of tamoxifen against several species of Leishmania, we now show its effectiveness in vitro and in vivo against an L. braziliensis isolate obtained from a Brazilian patient with CL and on a L. chagasi reference strain.

For in vivo efficacy tests, the tamoxifen dose was chosen based on previous reports that established the drug levels in mouse serum after ip administration of $25-100 \mathrm{mg} / \mathrm{kg} /$ day tamoxifen. ${ }^{10}$ The dosage scheme used in the present experiments did not lead to alteration of body weight or other toxic effects.

An ideal experimental model for L. braziliensis infections would be characterized by initial cutaneous lesions followed by spreading to mucocutaneous sites. Unfortunately, such a model is unavailable as yet. BALB/c mice infected in the ear dermis behave as a model of localized CL with erythema and oedema developing at the inoculation site after 3 weeks of infection and evolving to spontaneous healing within 10 weeks of infection. Consequently, to evaluate treatment efficacy, we compared lesion sizes and parasite burden at the lesion peak, 6 weeks after infection. Meglumine antimoniate's effect was more pronounced than tamoxifen's but both drugs significantly reduced the number of parasites at the site of infection. As expected, treatment with meglumine antimoniate did not lead to sterile cure, as observed previously in animal models as well as in humans. ${ }^{11}$ 


\section{Miguel et al.}

We have also established that tamoxifen, when administered to hamsters infected with L. chagasi, significantly reduces parasite numbers in both the liver and the spleen. Parasite burden quantified after treatment with tamoxifen was equivalent to that observed in animals receiving meglumine antimoniate. Outstandingly, the percentage of survival was identical between drug-treated groups, whereas saline-treated animals did not survive 18 weeks post-infection. Hamsters infected with L. chagasi develop a progressive disease closely mimicking active human VL. This is, therefore, an appropriate model to test the effect of tamoxifen on L. chagasi infection and confirm its effective leishmanicidal action.

The anti-oestrogen tamoxifen is one of the most prescribed anticancer drugs in the world. Indicated for treatment or prevention of breast cancer, it is used continuously for 5 years with daily doses of $20-40 \mathrm{mg} .{ }^{12}$ Clinical trials have extensively examined the side effects of tamoxifen and the most worrying consequence of prolonged use of this drug is the potential development of endometrial carcinoma. ${ }^{3}$ In this work, tamoxifen was effective as a short-term treatment. We have previously observed that this scheme does not induce changes in uterine weight or histopathology in BALB/c mice ${ }^{5}$ (data not shown).

The efficacy of tamoxifen was the same in male and female hamsters. As the majority of clinical experience with tamoxifen derives from its use in women, concerns could be raised about its toxicity in men. Interestingly, clinical trials have been conducted to determine tamoxifen's usefulness as an antimanic agent. ${ }^{13,14}$ Daily tamoxifen doses of $10-80 \mathrm{mg} /$ day for up to 3 weeks were well tolerated in a controlled test treating 29 patients diagnosed as having bipolar disorder. ${ }^{13}$ Another double-blind placebo-controlled study reported that $20-140 \mathrm{mg} /$ day tamoxifen for 3 weeks did not induce any severe adverse effect in men or women undergoing the treatment. Decreased appetite was the only statistically significant event with increased frequency in the tamoxifen group compared with placebo. ${ }^{14}$ These data indicate that tamoxifen could be safely used in men as well.

The data presented here together with our previously reported findings on tamoxifen's efficacy in L. amazonensis-infected mice ${ }^{5}$ provide the grounds to extend the tests to other models of Leishmania infection. This pioneering alternative may work as a novel chemotherapeutic approach to treat leishmaniasis.

\section{Acknowledgements}

We thank Dr Camila Indiani de Oliveira for her kind donation of the L. braziliensis BA788 strain. We also thank Manoel Aparecido Peres for excellent support in the animal house. We are very grateful to Dr Michel Rabinovitch for invaluable suggestions and support.

\section{Funding}

This work was funded by Fundação de Amparo à Pesquisa do Estado de São Paulo (FAPESP) and Conselho Nacional de
Desenvolvimento Científico e Tecnológico (CNPq). D. C. M. and R. C. Z.-N. were supported by FAPESP and CNPq fellowships, respectively.

\section{Transparency declarations}

None to declare.

\section{References}

1. Bern C, Maguire JH, Alvar J. Complexities of assessing the disease burden attributable to leishmaniasis. PLoS Negl Trop Dis 2008; 2: e313.

2. Murray WH, Berman JD, Davies $\mathrm{CR}$ et al. Advances in leishmaniasis. Lancet 2005; 366: 1561-77.

3. Jordan VC. Tamoxifen: a most unlikely pioneering medicine. Nat Rev Drug Discov 2003; 2: 205-13.

4. Miguel DC, Yokoyama-Yasunaka JK, Andreoli WK et al. Tamoxifen is effective against Leishmania and induces a rapid alkalinization of parasitophorous vacuoles harbouring Leishmania (Leishmania) amazonensis amastigotes. J Antimicrob Chemother 2007; 60: 526-34.

5. Miguel DC, Yokoyama-Yasunaka JK, Uliana SR. Tamoxifen is effective in the treatment of Leishmania amazonensis infections in mice. PLoS Negl Trop Dis 2008; 2: e249.

6. Gebre-Hiwot A, Tadesse G, Croft SL et al. An in vitro model for screening antileishmanial drugs: the human leukaemia monocyte cell line, THP-1. Acta Trop 1992; 51: 237-45.

7. de Moura TR, Novais FO, Oliveira F et al. Toward a novel experimental model of infection to study American cutaneous leishmaniasis caused by Leishmania braziliensis. Infect Immun 2005; 73: 5827-34.

8. Pontiggia $\mathrm{O}$, Rodriguez $\mathrm{V}$, Fabris $\mathrm{V}$ et al. Establishment of an in vitro estrogen-dependent mouse mammary tumor model: a new tool to understand estrogen responsiveness and development of tamoxifen resistance in the context of stromal-epithelial interactions. Breast Cancer Res Treat 2008, in press.

9. Beggs $\mathrm{WH}$. Drug protonation and $\mathrm{pH}$ in relation to the lethal action of tamoxifen on Candida albicans. $J$ Antimicrob Chemother 1996; 37: 841-2.

10. DeGregorio MW, Wilbur BJ, Coronado E et al. Serum tamoxifen concentrations in the athymic nude mouse after three methods of administration. Cancer Chemother Pharmacol 1987; 20: 316-8.

11. Vergel $\mathrm{C}$, Palacios $\mathrm{R}$, Cadena $\mathrm{H}$ et al. Evidence for Leishmania (Viannia) parasites in the skin and blood of patients before and after treatment. J Infect Dis 2006; 194: 503-11.

12. Vogel VG, Costantino JP, Wickerham DL et al. Effects of tamoxifen vs raloxifene on the risk of developing invasive breast cancer and other disease outcomes: the NSABP Study of Tamoxifen and Raloxifene (STAR) P-2 trial. JAMA 2006; 295: 2727-41.

13. Zarate CA Jr, Singh JB, Carlson PJ et al. Efficacy of a protein kinase $C$ inhibitor (tamoxifen) in the treatment of acute mania: a pilot study. Bipolar Disord 2007; 9: 561-70.

14. Yildiz A, Guleryuz S, Ankerst DP et al. Protein kinase C inhibition in the treatment of mania: a double-blind, placebo-controlled trial of tamoxifen. Arch Gen Psychiatry 2008; 65: 255-63. 
ANEXO C - Tamoxifen is effective in the treatment of Leishmania amazonensis infections in mice 


\title{
Tamoxifen Is Effective in the Treatment of Leishmania amazonensis Infections in Mice
}

\author{
Danilo C. Miguel, Jenicer K. U. Yokoyama-Yasunaka, Silvia R. B. Uliana*
}

Departamento de Parasitologia, Instituto de Ciências Biomédicas, Universidade de São Paulo, São Paulo, Brazil

\begin{abstract}
Background: Chemotherapy is still a critical issue in the management of leishmaniasis. Until recently, pentavalent antimonials, amphotericin B or pentamidine compounded the classical arsenal of treatment. All these drugs are toxic and have to be administered by the parenteral route. Tamoxifen has been used as an antiestrogen in the treatment and prevention of breast cancer for many years. Its safety and pharmacological profiles are well established in humans. We have shown that tamoxifen is active as an antileishmanial compound in vitro, and in this paper we analyzed the efficacy of tamoxifen for the treatment of mice infected with Leishmania amazonensis, an etiological agent of localized cutaneous leishmaniasis and the main cause of diffuse cutaneous leishmaniasis in South America.

Methodology/Principal Findings: BALB/c mice were infected with L. amazonensis promastigotes. Five weeks post-infection, treatment with 15 daily intraperitoneal injections of $20 \mathrm{mg} / \mathrm{kg}$ tamoxifen was administered. Lesion and ulcer sizes were recorded and parasite burden quantified by limiting dilution. A significant decrease in lesion size and ulcer development was noted in mice treated with tamoxifen as compared to control untreated animals. Parasite burden in the inoculation site at the end of treatment was reduced from $10^{8.5 \pm 0.7}$ in control untreated animals to $10^{5.0 \pm 0.0}$ in tamoxifen-treated mice. Parasite load was also reduced in the draining lymph nodes. The reduction in parasite number was sustained: 6 weeks after the end of treatment, $10^{15.5 \pm 0.5}$ parasites were quantified from untreated animals, as opposed to $10^{5.1 \pm 0.1}$ parasites detected in treated mice.

Conclusions/Significance: Treatment of BALB/C mice infected with L. amazonensis for 15 days with tamoxifen resulted in significant decrease in lesion size and parasite burden. BALB/c mice infected with $L$. amazonensis represents a model of extreme susceptibility, and the striking and sustained reduction in the number of parasites in treated animals supports the proposal of further testing of this drug in other models of leishmaniasis.
\end{abstract}

Citation: Miguel DC, Yokoyama-Yasunaka JKU, Uliana SRB (2008) Tamoxifen Is Effective in the Treatment of Leishmania amazonensis Infections in Mice. PLoS Negl Trop Dis 2(6): e249. doi:10.1371/journal.pntd.0000249

Editor: Charles Jaffe, Hebrew University, Israel

Received February 1, 2008; Accepted May 14, 2008; Published June 11, 2008

Copyright: (c) 2008 Miguel et al. This is an open-access article distributed under the terms of the Creative Commons Attribution License, which permits unrestricted use, distribution, and reproduction in any medium, provided the original author and source are credited.

Funding: This work was funded by Fundação de Amparo à Pesquisa do Estado de São Paulo (FAPESP) and Conselho Nacional de Desenvolvimento Científico e Tecnológico (CNPq). DCM was supported by a FAPESP fellowship. The funders had no role in study design, data collection and analysis, decision to publish, or preparation of the manuscript.

Competing Interests: The authors have declared that no competing interests exist.

*E-mail: srbulian@icb.usp.br

\section{Introduction}

Protozoan parasites of Leishmania genus are the etiological agents of leishmaniasis, a disease distributed worldwide with a broad spectrum of clinical manifestations according to the causative species and immunological status of the host. Leishmaniasis current therapy is mainly based on the systemic administration of toxic pentavalent antimonials or amphotericin B, drugs with several side effects, such as arrhythmia, nephro- and hepatotoxicity. Additionally, emergence of Leishmania strains resistant to antimonials has been reported [1],[2]. Recently, miltefosine has been approved in India for the therapy of visceral leishmaniasis [3], but its efficacy on the treatment of American cutaneous leishmaniasis has been shown to be variable depending on the causative species [4],[5],[6],[7]. Therefore, new alternatives for the treatment of leishmaniasis are greatly needed.

In South America, Leishmania amazonensis is one of the causative agents of localized cutaneous leishmaniasis and the most important agent of diffuse cutaneous leishmaniasis (DCL), a devastating disease with uncontrolled progression, characterized by multiple skin lesions and vaste numbers of amastigotes. As a rule, there is no satisfactory response to DCL treatment [8],[9].

We have previously shown that the antiestrogen tamoxifen, a drug extensively used as a chemotherapeutic and chemopreventive agent against breast cancer, presents leishmanicidal activity in vitro. This drug has a direct leishmanicidal effect and it also shifts the $\mathrm{pH}$ of parasitophorous vacuoles from acid to neutral, which in turn heightens the drug effect on amastigotes. Tamoxifen concentrations of approximately $10 \mu \mathrm{M}$ inhibit $50 \%$ of $L$. amazonensis viability and growth in vitro [10]. In the present study we demonstrate that $L$. amazonensis-infected BALB/c mice treated with tamoxifen for 2 weeks presented a significant reduction in lesion size and parasite burden.

\section{Materials and Methods}

The Ethics Committee that has approved this study is the Ethics Committee for Animal Experimentation of the Instituto de Ciências Biomédicas, University of São Paulo.

L. amazonensis promastigotes (MHOM/BR/1973/M2269) were grown in Medium 199 (Sigma-Aldrich) supplemented with 10\% 


\section{Author Summary}

Leishmaniasis is an antropozoonotic disease with a wide range of clinical manifestations. In humans, signs of disease vary from skin and mucosal ulcers to enlargement of internal organs such as the liver and spleen. The unicellular parasite Leishmania amazonensis is able to infect humans and cause localized or diffuse skin lesions. The treatment for this disease is difficult, as it requires prolonged and painful applications of toxic drugs that are poorly tolerated. Therefore, a key area in leishmaniasis research is the study of new therapeutic schemes and less toxic drugs. The present report is based on the investigation of tamoxifen's activity (a compound that has been in clinical use since the 1970s for the treatment of breast cancer) in the treatment of mice experimentally infected with L. amazonensis. We observed that infected mice treated with $20 \mathrm{mg} / \mathrm{kg} /$ day of tamoxifen for 15 days showed a significant clinical and parasitological response, with reduction in the size of lesions and ulcers and decreased numbers of parasites. These promising results pave the way for further testing of this drug as a new alternative in the chemotherapy of leishmaniasis.

heat-inactivated fetal calf serum (FCS; Invitrogen) and incubated at $25^{\circ} \mathrm{C}$. Female BALB/c mice (4-5 week-old) were inoculated with $5 \times 10^{6}$ stationary-phase parasites at the base of the tail. Five weeks after infection, mice were randomly assigned into experimental groups $(n=7-10)$. Treated groups received intraperitoneal injections of $30.4 \mathrm{mg}$ tamoxifen citrate $/ \mathrm{kg} /$ day (the drug equivalent to $20 \mathrm{mg} / \mathrm{kg} /$ day tamoxifen) or $20 \mathrm{mg} / \mathrm{kg} /$ day meglumine antimoniate (Glucantime) for 15 days. Tamoxifen citrate was purchased from Sigma-Aldrich, USA; Glucantime was a kind gift from Sanofi-Aventis. Stock solutions of tamoxifen were prepared in saline every two days and stored at $4^{\circ} \mathrm{C}$. Disease progression was evaluated once a week by recording the average diameter of the tail measured as the mean of tail base diameters in horizontal and vertical directions) and the ulcer size, expressed as the ulcer area in $\mathrm{mm}^{2}$. Measurements were taken with a caliper (Mitutoyo Corp., Japan). Body and uterus weights were also registered. Animal experiments were repeated four times and were approved by the Ethical Committee.

Parasite burden from infected tissue was quantified as described previously [11]. Promastigotes differentiated from lesion amastigotes were used on drug sensitivity assays while in the first passage in vitro. Cellular viability was assessed by measuring the cleavage of 3-(4,5dimethylthiazol-2-yl)-2,5-diphenyl tetrazolium bromide (MTT; Sigma-Aldrich) by metabolically active cells as described [12].

Data on lesion progression were analyzed for statistical significance by using the non-parametric Mann-Whitney test (GraphPad Prism 5 software). Results of limiting dilution assay were analyzed based on two-tailed Student $t$ test for paired samples using the ELIDA software. A result was considered significant at $P<0.05$.

\section{Results}

The treatment of L. amazonensis-infected BALB/c mice was initiated 5 weeks post-infection, time when lesions were already established and apparent. Mice were treated with $20 \mathrm{mg} / \mathrm{kg} /$ day tamoxifen intraperitoneally for 15 days. No toxic effects were detected during or after drug treatment. At the end of treatment, the average body weight in animals treated with tamoxifen was equivalent to values for the control group (untreated mice:
$26.2 \pm 1.1 \mathrm{~g}$; treated mice: $25.4 \pm 1.8 \mathrm{~g}$ ) and the average weight of uteri indicated no significant alteration between tamoxifentreated $(0.18 \pm 0.4 \mathrm{~g})$ and untreated mice $(0.21 \pm 0.6 \mathrm{~g})$. Figure $1 \mathrm{~A}$ shows the progression of lesion size in untreated versus tamoxifentreated mice. During and after tamoxifen administration we observed that treated animals presented less swelling at the infection site when compared to control animals. A statistically significant difference between the average thickness of lesions of untreated and tamoxifen-treated mice was evident on completion of treatment, at week 7 post-infection $(P<0.001)$ and remained clear until the end of the experiment (week 13, $P<0.01$ ), when control mice had to be euthanized. Macroscopical aspects of the lesions are displayed in Figure 1B for untreated (left column) and tamoxifen-treated animals (right column).

Since L. amazonensis infection in BALB/c mice normally evolves from swelling at the infection site to an ulcerated lesion with loss of tissue, the measurement of lesion thickness can be misleading at late time-points. So, another criteria used for evaluating disease progression was the appearance and enlargement of ulcers. Tamoxifen treated mice showed a very significant delay in the development of ulcers when compared with untreated mice (Figure 1C).

Parasite burden in tamoxifen-treated animals was evaluated immediately after the interruption of treatment 7 weeks after infection) and 6 weeks later (13 weeks after infection). As shown in Figure 2, a significant decrease on total parasite numbers per lesion on tamoxifen-treated animals was observed in both time points. At the end of the experiment, the average number of parasites was reduced by at least $99.7 \%$ in treated groups, as compared to untreated animals. These results were reproduced in 3 independent experiments.

In order to evaluate the activity of tamoxifen in parallel with a standard drug, a fourth experiment was performed with groups of 10 mice treated with $20 \mathrm{mg} / \mathrm{kg} /$ day tamoxifen, $20 \mathrm{mg} / \mathrm{kg} /$ day Glucantime or mock-treated with saline. Treatment was initiated 4 weeks after infection and carried on for 15 days with daily intraperitoneal infections. As shown in Table 1, three weeks after the end of treatment, there was no difference in the average size of lesions between mock and Glucantime-treated mice. The group that received tamoxifen showed a significant decrease in lesion thickness. Parasite burden was determined for the lesion site, draining lymph node and spleen. There was a significant reduction in the numbers of parasites recovered from tamoxifen treated mice as compared to mock or Glucantime groups both at the lesion and lymph node. No parasites were recovered from the spleen in any of the groups (Table 1). Therefore, tamoxifen proved to be more effective in this experimental model than the standard drug.

Finally, we investigated whether parasites remaining in tamoxifen treated groups were less sensitive to the drug. MTT viability assays showed that tamoxifen's activity against promastigotes derived from parasites extracted from treated or untreated mice remained unchanged with EC $50 \%$ of $11.5 \pm 1.1$ and 12.8 $\pm 2.8 \mu \mathrm{M}$, respectively. Therefore, remaining parasites did not develop resistance to tamoxifen during treatment.

\section{Discussion}

Our data reveal a significant effect of tamoxifen in the reduction of skin lesions caused by $L$. amazonensis in BALB/c mice. Effectiveness was apparent not only as reduced swelling and ulceration in treated animals but also as an important reduction in parasite burden.

The experimental model of infection used in this study is one of extreme susceptibility. BALB/c mice infected subcutaneously with 
A

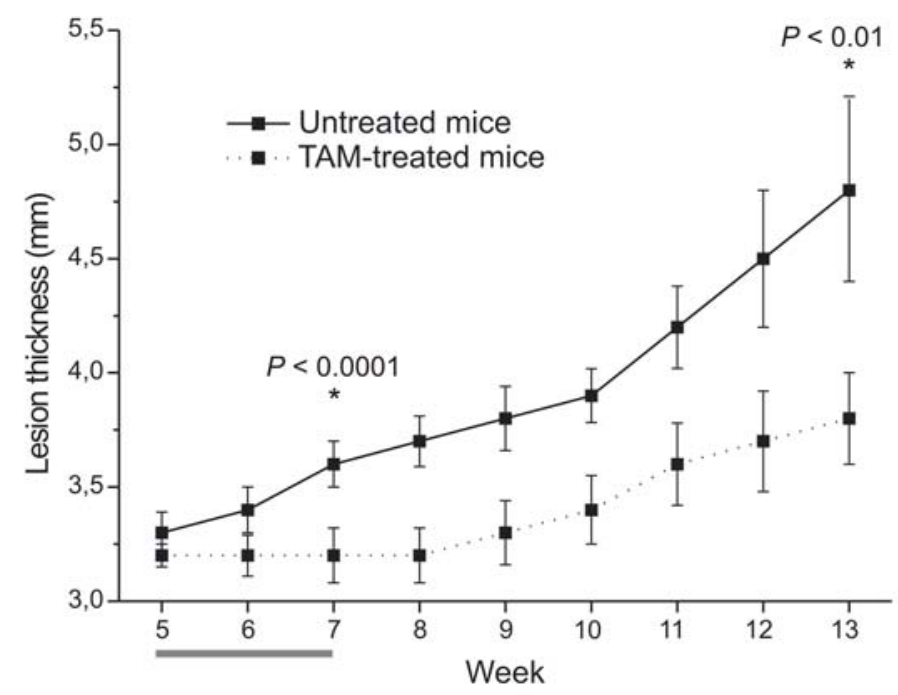

B

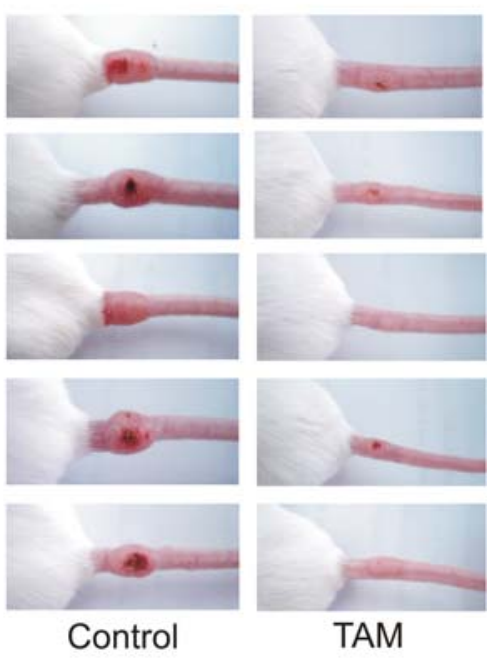

C

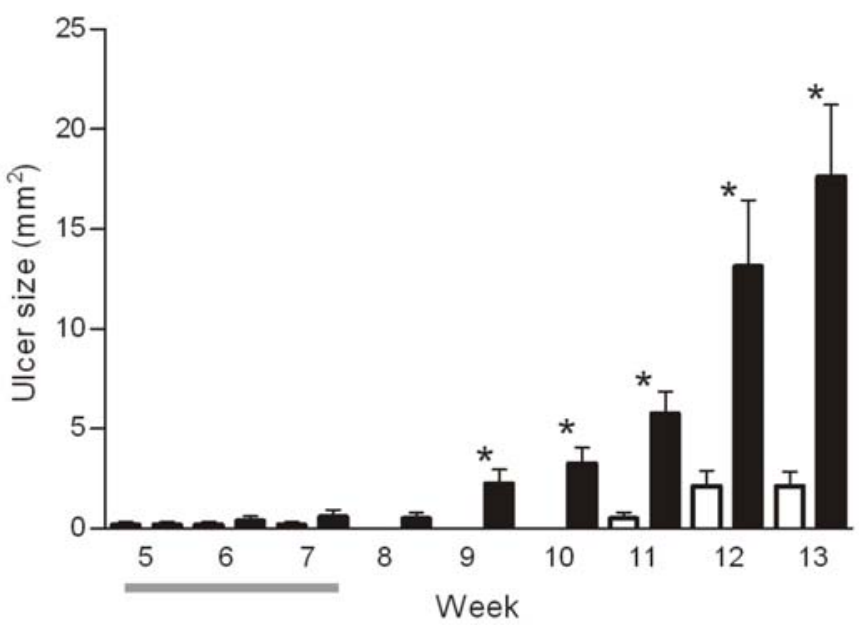

Figure 1. Follow up of $L$. amazonensis infection in BALB/c mice treated with tamoxifen (TAM). A: Progression of lesion thickness (mean \pm SD) in untreated (solid line) or TAM-treated (dotted line) mice. B: Macroscopical evaluation of lesions in untreated (left column) and TAMtreated mice (right column) at week 13 post-infection. C: Mean and SEM of ulcer size recorded from untreated (black bars) and TAM-treated animals (white bars). ${ }^{*} P<0.005$. Data represents one of three independent experiments. A and C: Horizontal grey bars indicate period of TAM administration ( $n=10$ per group from week 5 to 7 or $n=8$ per group after week 7 ). doi:10.1371/journal.pntd.0000249.g001

L. amazonensis develop progressive swelling at the inoculation site, followed by ulceration and loss of tissue simultaneous with the appearance of methastasis at distant sites. The treatment did not lead to sterile cure of lesions but Leishmania parasites have been shown to remain present and viable, although in decreased numbers, after treatment with antimonials in a variety of animal models, as well as in humans. The lack of clinical or parasitological response to Glucantime in L. amazonensis BALB/c infected mice has been reported previously [13].

Furthermore, the timing for initiation of treatment can significantly influence the disease outcome, as stressed by previous studies [14]. Our experimental treatments were initiated 3035 days after mice infection, an interval of time that allowed the establishment of disease and when infection sites were already swollen and, in some animals, had started ulcerating. So, the data shown here imply that the intraperitoneal administration of tamoxifen resulted in a remarkable response to treatment. We are currently evaluating tamoxifen's efficacy in the treatment of other models of cutaneous and visceral leishmaniasis. We have shown in vitro that tamoxifen leishmanicidal effect is independent of the estrogen receptor [10] and therefore it is unlikely that response to treatment would be different in male or female mice. Indeed, preliminary results obtained in Leishmania chagasi infected hamsters show no gender-related effect on the anti-leishmanial response to tamoxifen.

Apart from its direct leishmanicial activity, tamoxifen mode of action in vivo could involve other pathways favouring amelioration of the infection. Tamoxifen has been reported to increase synthesis of inducible nitric oxide synthase and production of nitric oxide [15]. We did not detect differences in the accumulation of nitrate on supernatants of $L$. amazonensis infected macrophages treated or not treated with tamoxifen (data not shown). 


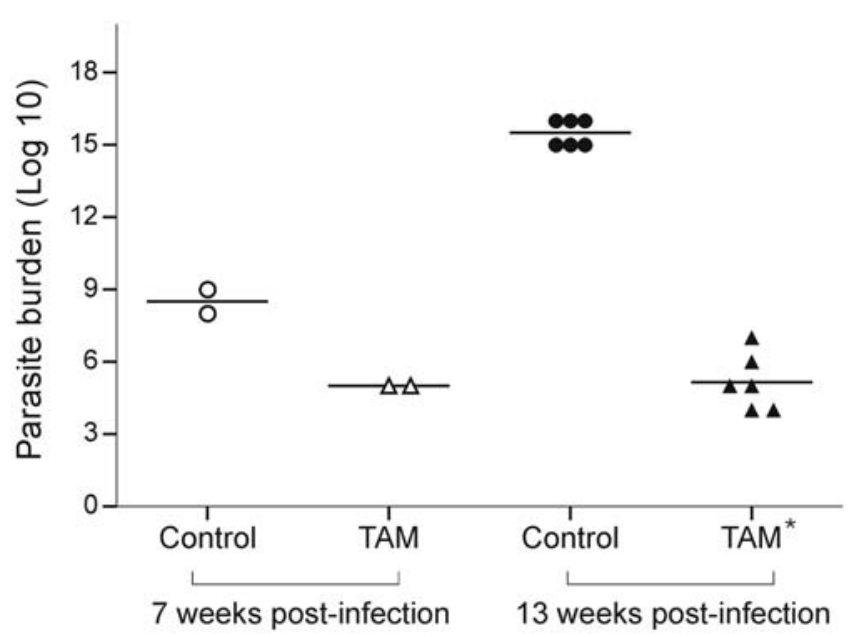

Figure 2. Parasite burden after treatment with tamoxifen (TAM). Number of parasites recovered by limiting dilution from mice infected with $L$. amazonensis and treated with TAM (triangles) and untreated controls (circles). Parasites were quantified from lesions removed immediately after the interruption of treatment (7 weeks post-infection; empty symbols; $\mathrm{n}=2$ ) or 6 weeks after interruption of treatment (13 weeks post-infection; filled symbols; $n=6$ ). ${ }^{*} P<0.0001$. doi:10.1371/journal.pntd.0000249.g002

The metabolite profile of tamoxifen varies in different animal models [16]. This drug has been used in mice in a variety of doses and administration schemes. The dosage employed in this study was chosen based on previous reports showing that, in mice, daily intraperitoneal injections of 25 to $100 \mathrm{mg} / \mathrm{kg}$ of tamoxifen resulted in drug serum levels similar to those observed in patients [17].

This antiestrogen has been widely used for treatment and prevention of breast cancer [18]. The most serious side effect observed on clinical grounds is an increased risk for endometrial cancer which appears after prolonged use. Effects observed in our experiments suggest that antileishmanial therapy with tamoxifen would not require extensive periods of treatment. We did not detect changes in uterine weight in treated female mice, a wellestablished parameter for evaluation of tamoxifen's toxicity [19]. Tamoxifen administered at $40 \mathrm{mg} / \mathrm{kg} /$ day for 4 weeks has been

\section{References}

1. Berman JD, Chulay JD, Hendricks LD, Oster CN (1982) Susceptibility of clinically sensitive and resistant Leishmania to pentavalent antimony in vitro. Am J Trop Med Hyg 31: 459-465.

2. Natera S, Machuca C, Padrón-Nieves M, Romero A, Díaz E, et al. (2007) Leishmania spp.: proficiency of drug-resistant parasites. Int J Antimicrob Agents 29: 637-642.

3. Sundar S, Jha TK, Thakur CP, Engel J, Sindermann H, et al. (2002) Oral miltefosine for Indian visceral leishmaniasis. N Engl J Med 347: 1739-1746.

4. Soto J, Valda-Rodriquez L, Toledo J, Vera-Navarro L, Luz M, et al. (2004) Comparison of generic to branded pentavalent antimony for treatment of new world cutaneous leishmaniasis. Am J Trop Med Hyg 71: 577-581.

5. Soto J, Berman J (2006) Treatment of New World cutaneous leishmaniasis with miltefosine. Trans R Soc Trop Med Hyg 100: 34-40.

6. Zerpa O, Ulrich M, Blanco B, Polegre M, Avila A, et al. (2007) Diffuse cutaneous leishmaniasis responds to miltefosine but then relapses. Br J Dermatol 156: $1328-1335$

7. Soto J, Rea J, Balderrama M, Toledo J, Soto P, et al. (2008) Efficacy of miltefosine for Bolivian cutaneous leishmaniasis. Am J Trop Med Hyg 78: 210-211.

8. Franke ED, Lucas CM, Tovar AA, Kruger JH, De Rivera MV, et al. (1990) Diffuse cutaneous leishmaniasis acquired in Peru. Am J Trop Med Hyg 43: 260-262.

9. Convit J, Ulrich M, Fernández CT, Tapia FJ, Cáceres-Dittmar G, et al. (1993) The clinical and immunological spectrum of American cutaneous leishmaniasis. Trans R Soc Trop Med Hyg 87: 444-448.

10. Miguel DC, Yokoyama-Yasunaka JK, Andreoli WK, Mortara RA, Uliana SR (2007) Tamoxifen is effective against Leishmania and induces a rapid
Table 1. Evaluation of disease progression and parasite burden in L. amazonensis-infected mice 3 weeks after the end of treatment.

\begin{tabular}{|c|c|c|c|c|}
\hline & & Saline & $\begin{array}{l}\text { Glucantime } \\
(20 \mathrm{mg} / \mathrm{kg} / \mathrm{d})^{a}\end{array}$ & $\begin{array}{l}\text { Tamoxifen } \\
(20 \mathrm{mg} / \mathrm{kg} / \mathrm{d})\end{array}$ \\
\hline \multicolumn{2}{|c|}{ Lesion thickness $(\mathrm{mm})^{b}$} & $4.0 \pm 0.2$ & $4.1 \pm 0.2$ & $3.6 \pm 0.1$ \\
\hline \multirow[t]{3}{*}{ Parasite burden } & Lesion site ${ }^{c}$ & $10^{5.4 \pm 0.7}$ & $10^{8.3 \pm 0.8}$ & $10^{3.0 \pm 0.1}$ \\
\hline & Lymph node ${ }^{d}$ & $10^{3.7 \pm 0.7}$ & $10^{5.3 \pm 1.2}$ & $10^{2.0 \pm 0.1}$ \\
\hline & Spleen & $\mathrm{nd}^{\mathrm{e}}$ & nd & nd \\
\hline \multicolumn{2}{|c|}{ Spleen weight (g) } & $0.1 \pm 0.0$ & $0.1 \pm 0.0$ & $0.1 \pm 0.0$ \\
\hline
\end{tabular}

a equivalent to $5.4 \mathrm{mg} \mathrm{Sb} / \mathrm{kg} /$ day.

${ }^{b}$ Saline vs Tamoxifen: $P<0.05$ and Glucantime vs Tamoxifen: $P<0.005$.

c, dSaline vs Tamoxifen and Glucantime vs Tamoxifen: $P<0.05$.

${ }^{\mathrm{e}}$ (nd) not detectable.

doi:10.1371/journal.pntd.0000249.t001

recently shown to impair bone growth in rats [20] raising concerns on the application of this drug to treat leishmaniasis in children. We are also investigating the effect of other selective estrogen receptor modulators with different effects in bone metabolism, like raloxifene, as antileishmanial drugs.

The potential value of tamoxifen for treating human leishmaniasis needs further evaluation. To the best of our knowledge, this is the first report of an in vivo investigation on tamoxifen's efficacy against Leishmania infection and points to a new alternative in the treatment of leishmaniasis.

\section{Acknowledgments}

We thank Rogéria Zauli-Nascimento for support with animal experiments, Dr. Telma Maria Tenório Zorn, for helpful discussions and assistance with evaluation of mice uteri, and Manoel Aparecido Peres for excellent technical support in the animal house.

\section{Author Contributions}

Conceived and designed the experiments: DM SU. Performed the experiments: DM JY. Analyzed the data: DM JY SU. Wrote the paper: DM JY SU.

alkalinization of parasitophorous vacuoles harbouring Leishmania (Leishmania) amazonensis amastigotes. J Antimicrob Chemother 60: 526-534.

11. Lima HC, Bleyenberg JA, Titus RG (1997) A simple method for quantifying Leishmania in tissues of infected animals. Parasitol Today 13: 80-82.

12. Barcinski MA, Schechtman D, Quintao LG, Costa Dde A, Soares LR, et al. (1992) Granulocyte-macrophage colony-stimulating factor increases the infectivity of Leishmania amazonensis by protecting promastigotes from heat-induced death. Infect Immun 60: 3523-3527.

13. Gonçalves GS, Fernandes AP, Souza RC, Cardoso JE, de Oliveira-Silva F, et al. (2005) Activity of a paromomycin hydrophilic formulation for topical treatment of infections by Leishmania (Leishmania) amazonensis and Leishmania (Viannia) braziliensis. Acta Trop 93: 161-167.

14. Garnier T, Mäntylä A, Järvinen T, Lawrence J, Brown M, et al. (2007) In vivo studies on the antileishmanial activity of buparvaquone and its prodrugs. J Antimicrob Chemother 60: 802-810.

15. Loo SA, Lesoon-Wood LA, Cooney RV (1998) Effects of tamoxifen on nitric oxide synthesis and neoplastic transformation in C3H 10T1/2 fibroblasts. Cancer Lett 122: 67-75.

16. Robinson SP, Langan-Fahey SM, Johnson DA, Jordan VC (1991) Metabolites, pharmacodynamics, and pharmacokinetics of tamoxifen in rats and mice compared to the breast cancer patient. Drug Metab Dispos 19: 36-43.

17. DeGregorio MW, Wilbur BJ, Coronado E, Osborne CK (1987) Serum tamoxifen concentrations in the athymic nude mouse after three methods of administration. Cancer Chemother Pharmacol 20: 316-318.

18. Jordan VC (2007) New insights into the metabolism of tamoxifen and its role in the treatment and prevention of breast cancer. Steroids 72: 829-842. 
19. Perry MJ, Gujra S, Whitworth T, Tobias JH (2005) Tamoxifen stimulates cancellous bone formation in long bones of female mice. Endocrinology 146: 1060-1065.
20. Karimian E, Chagin AS, Gjerde J, Heino T, Lien EA, Ohlsson C, Sävendahl L (2008) Tamoxifen Impairs Both Longitudinal and Cortical Bone Growth in Young Male Rats. J Bone Miner Res. In press. 
ANEXO D - Clinical isolates of New World Leishmania from cutaneous and visceral leishmaniasis patients are uniformly sensitive to tamoxifen 


\section{Clinical isolates of New World Leishmania from cutaneous and visceral leishmaniasis patients are uniformly sensitive to tamoxifen}

Sir,

Leishmaniasis affects 12 million people worldwide. Chemotherapy of leishmaniasis relies mainly on expensive and toxic drugs, and great efforts are being directed towards identifying new candidate drugs for the treatment of this neglected disease. We have recently described the activity of tamoxifen, a selective oestrogen receptor modulator, as an antileishmanial agent. Tamoxifen has been shown to possess in vitro activity against visceralising and cutaneous strains of Leishmania such as Leishmania donovani, Leishmania infantum chagasi, Leishmania braziliensis, Leishmania amazonensis and Leishmania major. Half maximal effective concentrations $\left(\mathrm{EC}_{50}\right)$ of tamoxifen for these parasites range from $9.3 \pm 0.3 \mu \mathrm{M}$ to $19.9 \pm 0.3 \mu \mathrm{M}$ in vitro and the drug is active against promastigotes and intracellular amastigotes at the same range of effective doses [1-3]. We have also demonstrated that treatment with tamoxifen for 15 days in rodent models of cutaneous and visceral leishmaniasis is able to control the disease with equal or better effectiveness as the standard antimonial treatment [2,3]. The aim of this study was to determine whether the antileishmanial activity of tamoxifen previously reported holds true for recent Leishmania isolates obtained from cutaneous and visceral leishmaniasis patients in Brazil.

Thirteen isolates of Leishmania spp. were obtained from patients attending the Anuar Auad Hospital for Tropical Diseases in Goiânia (Goiás, Brazil) and six isolates were from patients from Natal, Rio Grande do Norte, Brazil. Parasite isolation was obtained from lesion biopsies or bone marrow aspirates performed as part of the diagnostic procedure. Parasites were typed by isoenzyme electrophoresis at Instituto Oswaldo Cruz (Rio de Janeiro, Brazil) or by polymerase chain reaction (PCR) [4,5]. Promastigotes of $L$. (L.) infantum chagasi (MHOM/BR/1972/LD), L. (Viannia) braziliensis (MHOM/BR/75/M2903) and L. (L.) amazonensis (MHOM/BR/73/M2269) reference strains as well as of the clinical isolates were grown as described previously [1,3]. Promastigote drug susceptibility assays were performed by incubating parasites in the presence of increasing concentrations of tamoxifen $(2.5-30 \mu \mathrm{M})$ or the control drug amphotericin $\mathrm{B}(\mathrm{AmB})(0.05-3 \mu \mathrm{M})$ for $24 \mathrm{~h}$. Viability was assessed by MTT cleavage as described previously [5]. Drug activity against intracellular amastigotes was tested using BALB/c bone marrow-derived macrophages (BMDMs) as described previously [5]. Briefly, infected BMDMs were treated with increasing concentrations of tamoxifen (3-12 $\mu \mathrm{M})$ or AmB. Half maximal cytotoxic concentrations of tamoxifen for BMDMs ranged from $20 \mu \mathrm{M}$ to $30 \mu \mathrm{M}$. $\mathrm{EC}_{50}$ and $\mathrm{EC}_{90}$ (effective concentrations needed to control $50 \%$ and $90 \%$ of the parasites, respectively) values were determined from sigmoidal regression of the concentration-response curves using Origin 7.5 software (OriginLab Corp., Northampton, MA). Experiments were repeated at least twice using triplicate samples.

Table 1 shows the results of sensitivity testing for the 19 clinical isolates as well as the corresponding type strains included as test controls. Amongst six L. infantum chagasi isolates the $\mathrm{EC}_{50}$ for promastigotes ranged from $6.2 \mu \mathrm{M}$ to $10.4 \mu \mathrm{M}$, whilst for $L$. braziliensis the $\mathrm{EC}_{50}$ varied from $6.0 \mu \mathrm{M}$ to $10.9 \mu \mathrm{M}$. The highest $\mathrm{EC}_{50}(14.8 \mu \mathrm{M})$ was detected in a L. amazonensis isolate, well within the expected range based on data previously obtained with the type strains. Values determined for the $\mathrm{EC}_{90}$ against promastigotes of all cultured parasites were also uniform, with a mean of $16.95 \mu \mathrm{M}$ [95\% confidence interval (CI) 15.07-18.82 $\mu \mathrm{M}$ ]. These findings are consistent with homogeneous sensitivity to the drug in the field, supported by the lack of significant differences between the isolates $(P=0.6479$, Kruskal-Wallis test).

The sensitivity of amastigotes of 12 field isolates was also tested. In all cases but one, the $\mathrm{EC}_{50}$ for amastigotes was lower than the $\mathrm{EC}_{50}$ for promastigotes of the same isolate by a factor of 2-3 (Table 1). One isolate of $L$. amazonensis exhibited the same $\mathrm{EC}_{50}$ for promastigotes and amastigotes. We had previously observed with type strains that the sensitivity to tamoxifen of promastigotes and amastigotes of a given species was in the same order of magnitude, with amastigotes being slightly more sensitive. This early finding was corroborated now by comparing the $\mathrm{EC}_{50}$ means for promastigotes and amastigotes of 12 field isolates (promastigotes, mean $\mathrm{EC}_{50}=9.16 \mu \mathrm{M}, 95 \% \mathrm{CI} 7.93-10.40 \mu \mathrm{M}$; and amastigotes, mean $\left.\mathrm{EC}_{50}=4.51 \mu \mathrm{M}, 95 \% \mathrm{CI} 3.58-5.43 \mu \mathrm{M}\right)$. We therefore confirmed that promastigote testing can be used to evaluate Leishmania sensitivity to tamoxifen.

Of the 19 isolates tested in this work, 13 had been studied previously and their sensitivity to pentavalent antimony and $\mathrm{AmB}$ determined [5]. Interestingly, whilst their sensitivity to AmB was also uniform, pentavalent antimony effectiveness was less regular, with $\mathrm{EC}_{50}$ values against intracellular amastigotes varying up to 8 -fold [5].

This study offers support and justification for considering tamoxifen as a candidate for further development as an antileishmanial agent.

Funding: This work was supported by Conselho Nacional de Desenvolvimento Científico e Tecnológico (CNPq), Fundação de Amparo à Pesquisa do Estado de São Paulo (FAPESP), Fundação de Amparo à Pesquisa do Estado de Goiás (FAPEG) and Coordenação de Aperfeiçoamento de Pessoal de Nível Superior (CAPES). Fellowship support to DCM was provided by FAPESP and to RCZN by CNPq.

Competing interests: None declared.

Ethical approval: This study was approved by the Ethics Committee for Animal Experimentation of the Instituto de Ciências Biomédicas da Universidade de São Paulo (approval certificate 033/07). The study was also approved by the Ethical Committees on Human and Animal Research of the Universidade 
Table 1

Susceptibility of Leishmania isolates to tamoxifen and the control drug amphotericin B (AmB).

\begin{tabular}{|c|c|c|c|c|c|c|c|}
\hline \multirow[t]{3}{*}{ Species } & \multirow[t]{3}{*}{ Isolate } & \multicolumn{4}{|c|}{ Tamoxifen $(\mu \mathrm{M})$} & \multirow{2}{*}{\multicolumn{2}{|c|}{$\frac{\mathrm{AmB}(\mathrm{ng} / \mathrm{ml})}{\text { Promastigotes }}$}} \\
\hline & & \multicolumn{2}{|c|}{ Promastigotes } & \multicolumn{2}{|c|}{ Amastigotes } & & \\
\hline & & $\mathrm{EC}_{50} \pm$ S.D. & $\mathrm{EC}_{90}$ & $\mathrm{EC}_{50} \pm$ S.D. & $\mathrm{EC}_{90}$ & $\mathrm{EC}_{50} \pm$ S.D. & $\mathrm{EC}_{90}$ \\
\hline L. (L.) infantum chagasi & MHOM/BR/1972/LD & $7.8 \pm 0.97$ & 26.2 & $2.8 \pm 0.09$ & 5.9 & $27.2 \pm 0.04$ & 110.0 \\
\hline L. (L.) infantum chagasi & $\mathrm{MHOM} / \mathrm{BR} / 2005 / 3050$ & $9.2 \pm 0.41$ & 17.2 & $3.3 \pm 0.01$ & 4.9 & $27.6 \pm 0.30$ & 59.0 \\
\hline L. (L.) infantum chagasi & MHOM/BR/2005/3052 & $10.4 \pm 0.40$ & 14.8 & $3.9 \pm 0.01$ & 6.4 & $36.8 \pm 0.50$ & 64.4 \\
\hline L. (L.) infantum chagasi & MHOM/BR/2005/3071 & $7.4 \pm 0.70$ & 14.8 & $2.6 \pm 0.17$ & 6.2 & $18.4 \pm 1.20$ & 60.7 \\
\hline L. (L.) infantum chagasi & MHOM/BR/2009/340BM & $9.4 \pm 0.47$ & 12.5 & $3.7 \pm 0.26$ & 7.9 & $26.6 \pm 0.40$ & 46.9 \\
\hline L. (L.) infantum chagasi & MHOM/BR/2009/340SK & $6.2 \pm 0.17$ & 11.3 & $3.1 \pm 0.08$ & 6.1 & $14.6 \pm 1.60$ & 33.2 \\
\hline L. (L.) infantum chagasi & MHOM/BR/2009/341 & $9.7 \pm 0.22$ & 13.9 & $3.9 \pm 0.49$ & 8.0 & $21.8 \pm 0.80$ & 39.7 \\
\hline L. (L.) amazonensis & $\mathrm{MHOM} / \mathrm{BR} / 73 / \mathrm{M} 2269$ & $11.4 \pm 2.53$ & 21.9 & $6.8 \pm 0.15$ & 11.0 & $114.8 \pm 0.67$ & 227.8 \\
\hline L. (L.) amazonensis & MHOM/BR/2004/EGS4 & $14.8 \pm 0.99$ & 22.7 & $6.8 \pm 0.37$ & 8.6 & $68.0 \pm 3.80$ & 213.2 \\
\hline L. (L.) amazonensis & MHOM/BR/2001/JRS1 & $9.0 \pm 2.93$ & 24.6 & $4.5 \pm 1.17$ & 9.8 & $58.9 \pm 0.14$ & 304.5 \\
\hline L. (L.) amazonensis & MHOM/BR/2006/JSC6 & $7.2 \pm 0.47$ & 14.8 & $7.2 \pm 0.88$ & 11.3 & $75.8 \pm 1.20$ & 175 \\
\hline L. (Viannia) braziliensis & MHOM/BR/75/M2903 & $10.8 \pm 3.70$ & 19.7 & $5.6 \pm 0.3$ & 9.0 & $93.0 \pm 12.27$ & 355 \\
\hline L. (V.) braziliensis & MHOM/BR/2006/BES6 & $6.0 \pm 0.93$ & 12.2 & $3.5 \pm 0.15$ & 7.3 & $53.9 \pm 1.10$ & 141 \\
\hline L. (V.) braziliensis & MHOM/BR/2006/EFSF6 & $9.3 \pm 0.80$ & 18.3 & $6.9 \pm 0.02$ & 9.8 & $41.5 \pm 1.12$ & 494 \\
\hline L. (V.) braziliensis & MHOM/BR/2006/GDL6 & $8.9 \pm 1.05$ & 14.0 & $3.0 \pm 0.03$ & 7.9 & $52.1 \pm 2.38$ & 237 \\
\hline L. (V.) braziliensis & MHOM/BR/2006/HPV6 & $10.9 \pm 0.41$ & 16.9 & $\mathrm{~N} / \mathrm{D}$ & $\mathrm{N} / \mathrm{D}$ & $56.5 \pm 0.98$ & 170 \\
\hline L. (V.) braziliensis & MHOM/BR/2003/IMG3 & $9.2 \pm 0.36$ & 14.8 & $\mathrm{~N} / \mathrm{D}$ & $\mathrm{N} / \mathrm{D}$ & $77.8 \pm 0.53$ & 253 \\
\hline L. (V.) braziliensis & MHOM/BR/2006/PPS6m & $9.1 \pm 0.95$ & 21.5 & $\mathrm{~N} / \mathrm{D}$ & $\mathrm{N} / \mathrm{D}$ & $37.9 \pm 8.59$ & 430 \\
\hline L. (V.) braziliensis & MHOM/BR//2005/RPL5 & $8.4 \pm 0.41$ & 15.6 & $\mathrm{~N} / \mathrm{D}$ & $\mathrm{N} / \mathrm{D}$ & $54.8 \pm 0.02$ & 87 \\
\hline L. (V.) braziliensis & MHOM/BR/2006/TMB6 & $8.4 \pm 0.20$ & 14.1 & $\mathrm{~N} / \mathrm{D}$ & $\mathrm{N} / \mathrm{D}$ & $49.5 \pm 0.43$ & 100 \\
\hline L. (V.) braziliensis & MHOM/BR/2006/UAF6 & $9.1 \pm 0.05$ & 14.6 & $\mathrm{~N} / \mathrm{D}$ & $\mathrm{N} / \mathrm{D}$ & $86.3 \pm 1.30$ & 154 \\
\hline L. (V.) braziliensis & MHOM/BR/2005/WSS5 & $6.5 \pm 0.57$ & 12.4 & $\mathrm{~N} / \mathrm{D}$ & $\mathrm{N} / \mathrm{D}$ & $50.7 \pm 1.06$ & 81 \\
\hline
\end{tabular}

$\mathrm{EC}_{50}$, half maximal (50\%) effective concentration; S.D., standard deviation; EC 90 , effective concentration needed to control $90 \%$ of the parasites; N/D, not determined.

Federal de Goiás and the Universidade Federal do Rio Grande do Norte.

\section{References}

[1] Miguel DC, Yokoyama-Yasunaka JK, Andreoli WK, Mortara RA, Uliana SR. Tamoxifen is effective against Leishmania and induces a rapid alkalinization of parasitophorous vacuoles harbouring Leishmania (Leishmania) amazonensis amastigotes. J Antimicrob Chemother 2007;60:526-34.

[2] Miguel DC, Yokoyama-Yasunaka JK, Uliana SR. Tamoxifen is effective in the treatment of Leishmania amazonensis infections in mice. PLoS Negl Trop Dis 2008;2:e249.

[3] Miguel DC, Zauli-Nascimento RC, Yokoyama-Yasunaka JK, Katz S, Barbiéri CL, Uliana SR. Tamoxifen as a potential antileishmanial agent: efficacy in the treatment of Leishmania braziliensis and Leishmania chagasi infections. J Antimicrob Chemother 2009;63:365-8.

[4] Dweik A, Schönian G, Mosleh IM, Karanis P. Evaluation of PCR-RFLP(based on ITS1 and HaeIII) for the detection of Leishmania species, using Greek canine isolates and Jordanian clinical material. Ann Trop Med Parasitol 2007;101:399-407.

[5] Zauli-Nascimento RC, Miguel DC, Yokoyama-Yasunaka JK, Pereira LIA, Pelli de Oliveira MA, Ribeiro-Dias F, et al. In vitro sensitivity of Leishmania (Viannia) braziliensis and Leishmania (Leishmania) amazonensis Brazilian isolates to meglumine antimoniate and amphotericin B. Trop Med Int Health 2010;15:68-76.

Danilo C. Miguel Rogéria C. Zauli-Nascimento Jenicer K.U. Yokoyama-Yasunaka Departamento de Parasitologia, Instituto de Ciências Biomédicas, Universidade de São Paulo, São Paulo, Brazil
Ledice I.A. Pereira Instituto de Patologia Tropical e Saúde Pública, Universidade Federal de Goiás, Goiânia, Brazil

Selma M.B. Jerônimo Departamento de Bioquímica, Universidade Federal do Rio Grande do Norte, Natal, Rio Grande do Norte, Brazil

Fátima Ribeiro-Dias Miriam L. Dorta Instituto de Patologia Tropical e Saúde Pública, Universidade Federal de Goiás, Goiânia, Brazil

Silvia R.B. Uliana*

Departamento de Parasitologia, Instituto de Ciências Biomédicas, Universidade de São Paulo, São Paulo, Brazil

* Corresponding author. Tel.: +55 113091 7334; fax: +55 113091

7417. E-mail address: srbulian@icb.usp.br (S.R.B. Uliana) 
ANEXO E - The anticancer drug tamoxifen is active against Trypanosoma cruzi in vitro but ineffective in the treatment of the acute phase of Chagas disease in mice 


\title{
The anticancer drug tamoxifen is active against Trypanosoma cruzi in vitro but ineffective in the treatment of the acute phase of Chagas disease in mice
}

\author{
Danilo Ciccone Miguel ${ }^{1}$, Marcela Lencine Ferraz ${ }^{2}$, Rosana de Oliveira Alves ${ }^{2}$, \\ Jenicer KU Yokoyama-Yasunaka', Ana Claudia Torrecilhas', Alvaro José Romanha ${ }^{2}$, Silvia RB Uliana'1+ \\ ${ }^{1}$ Departamento de Parasitologia, Instituto de Ciências Biomédicas, Universidade de São Paulo, \\ Av. Prof. Lineu Prestes 1374, 05508-000 São Paulo, SP, Brasil \\ ${ }^{2}$ Laboratório de Parasitologia Celular e Molecular, Instituto de Pesquisas René Rachou-Fiocruz, Belo Horizonte, MG, Brasil
}

The activity of the antineoplastic drug tamoxifen was evaluated against Trypanosoma cruzi. In vitro activity was determined against epimastigote, trypomastigote and amastigote forms of CL14, Y and Y benznidazole resistant $\mathrm{T}$. cruzi strains. Regardless of the strain used, the drug was active against all life-cycle stages of the parasite with a half maximal effective concentration ranging from 0.7-17.9 $\mu \mathrm{M}$. Two experimental models of acute Chagas disease were used to evaluate the in vivo efficacy of treatment with tamoxifen. No differences in parasitemia and mortality were observed between control mock-treated and tamoxifen-treated mice.

Key words: chemotherapy - Chagas disease - selective oestrogen receptor modulator

Chemotherapy of Chagas disease remains a major challenge in the Americas. As a result of sustained campaigns of vector control, the number of new infections in endemic areas has decreased, but the disease still afflicts 10-15 million people in Latin America (Schofield et al. 2006). No satisfactory treatment for Trypanosoma cruzi infection is available (Pérez-Molina et al. 2009); currently used drugs are toxic and have disputable efficacy in the treatment of chronic infections (Marin-Neto et al. 2009).

Tamoxifen is a triphenylethylene that has been in clinical use for the treatment and chemoprevention of breast cancer since 1971 (Jordan 2003). It has been shown to inhibit the growth of promastigotes and intracellular amastigotes of several species of Leishmania (Miguel et al. 2007, 2009). Tamoxifen was also effective against the parasite in vivo, as shown in various experimental rodent models of visceral and cutaneous leishmaniasis. In all models tested, parasite burden and/or lesion progression decreased significantly after intraperitoneal administration of $20 \mathrm{mg} / \mathrm{kg} /$ day tamoxifen for 15 days (Miguel et al. 2008, 2009).

Leishmania and Trypanosoma belong to the Trypanosomatidae family, are genetically related and share many biochemical pathways, as shown by comparative analysis of their respective genomes (El-Sayed et al.

\footnotetext{
Financial support: FAPESP, FIOCRUZ, CNPq

DCM is the recipient of a post-graduate fellowship from FAPESP (05/59881-0).

DCM and MLF contributed equally to this work.

+ Corresponding author: srbulian@icb.usp.br

Received 1 July 2010

Accepted 1 September 2010
}

2005) and by comparative biochemical studies (Michels et al. 2006, Landfear 2008, Stuart et al. 2008). In this study, we evaluated the activity of tamoxifen against $T$. cruzi in vitro and in vivo.

The T. cruzi strains used were CL-14 (Brener \& Chiari 1963), Y (Silva \& Nussenzweig 1953) and a benznidazoleresistant line derived from the Y strain (BZR) (Murta \& Romanha 1998). Epimastigotes were grown in liver infusion-tryptose medium (LIT) supplemented with $10 \%$ fetal calf serum (FCS) and maintained at $25^{\circ} \mathrm{C}$ (Camargo 1964). The activity of tamoxifen (Sigma-Aldrich) against epimastigotes was assayed by counting the number of motile forms in a hemocytometer after incubating parasites with increasing concentrations of the drug for $24 \mathrm{~h}$.

To analyze the effect of tamoxifen on intracellular parasites, metacyclic trypomastigotes harvested from LIT cultures at the stationary growth phase were used to infect LLC-MK2 (rhesus monkey kidney, ATCC-CCL7) cells at a ratio of 50:1 parasites/host cell. Cultures were maintained at $34^{\circ} \mathrm{C}$ and $5 \% \mathrm{CO}_{2}$ in Roswell Park Memorial Institute (RPMI) medium (Sigma-Aldrich), supplemented with $2 \%$ FCS for $24 \mathrm{~h}$, washed to remove free parasites and then incubated for $48 \mathrm{~h}$ with increasing concentrations of tamoxifen. Infected cells were maintained at $34^{\circ} \mathrm{C}$ in an atmosphere of $5 \% \mathrm{CO}_{2}$ and the medium was replaced every $24 \mathrm{~h}$. After drug exposure, the untreated and treated infected cell cultures were fixed and stained with the Instant Prov kit (Newprov, Pinhais, Brazil). The number of infected host cells was determined using at least 400 host cells for two independent experiments run in triplicate.

Trypomastigotes were obtained from the blood of infected mice. To obtain sufficient numbers of parasites for drug susceptibility tests, these trypomastigotes were used to infect Vero cell cultures, which were maintained at $37^{\circ} \mathrm{C}$ and $5 \% \mathrm{CO}_{2}$ in Dulbecco's Modified Eagle's Medium supplemented with $10 \%$ FCS, as previously described (Santos 2008). Trypomastigotes released on the 
culture supernatant were recovered after 6-8 days, resuspended in RPMI without phenol red and incubated with increasing concentrations of tamoxifen for $24 \mathrm{~h}$ at $37^{\circ} \mathrm{C}$. The number of viable parasites was then assessed using the vital stain Alamar Blue (Invitrogen). Parasites were incubated with $10 \%$ Alamar Blue for $24 \mathrm{~h}$ at $37^{\circ} \mathrm{C}$ and the reduction of resazurin was monitored at $570 \mathrm{~nm}$ using $600 \mathrm{~nm}$ as a reference wavelength (Santos 2008). The percentage of viable cells was determined by comparison with control untreated cultures.

The half maximal effective concentration $\left(\mathrm{EC}_{50}\right)$ values for the T. cruzi populations were determined from sigmoidal regression of the concentration-response curves using Scientific Graphing and Analysis Software Origin 5.0. Experiments were performed in triplicate and repeated at least twice.

In vivo experiments were approved by the Ethical Committee for Animal Experimentation of the Institute of Biomedical Sciences of São Paulo University (approval certificates 033/07 and 067/08). Animals were bred, handled and maintained according to the Brazilian rules and regulations of animal experimentation. Acute infections were performed as described (Filardi \& Brener 1987). $\mathrm{BALB} / \mathrm{c}$ and Swiss Webster female and male mice were used (8-10 animals/experimental group). Infections were initiated by intraperitoneal inoculation of 5,000 T. cruzi $\mathrm{Y}$ strain tissue culture trypomastigotes/Swiss Webster mouse and 500 parasites/BALB/c mouse, due to the increased sensitivity of BALB/c mice to infection. Tamoxifen treatment was initiated on the 4th day of infection for Swiss Webster mice and on the 2nd day for BALB/c mice. Tamoxifen citrate was tested at $10,20,25$ and $50 \mathrm{mg} / \mathrm{kg} /$ day of drug equivalent for 15-20 days. Benznidazole (BZ) (Rochagan, Roche Co) was used as a reference drug at $100 \mathrm{mg} / \mathrm{kg}$ /day. Infected animals that received only saline were used as control groups. Parasitemia was assessed every other day from the 2nd day of infection by counting the trypomastigotes in a $5 \mu \mathrm{L}$ blood sample obtained from the tail vein. Surviving animals were monitored for 60 days and then subjected to hemoculture, used as a criterion of cure (Brener 1962). Tamoxifen citrate $(6 \mathrm{mg} / \mathrm{mL})$ and BZ $(6.25 \mathrm{mg} / \mathrm{mL})$ solutions were prepared in $150 \mathrm{mM}$ $\mathrm{NaCl}, \mathrm{pH}$ 7.2-7.4.

The table shows the in vitro activity of tamoxifen against $T$. cruzi strains and life stages. The drug was active against all $T$. cruzi life stages tested, with increased susceptibility noted for the infective mammalian stages, trypomastigotes and amastigotes. $\mathrm{EC}_{50}$ values calculated for epimastigotes of CL14, Y and BZR strains were similar, indicating homogeneous sensitivity between different strains and showing that resistance to BZ does not have an impact on sensitivity to tamoxifen.

The efficacy of tamoxifen in the control of acute infections was initially tested in female Swiss mice (Figs 1-3). Parasitemia peaks were reached at the 8th day after infection. The treatment of infected mice with 10,25 or $50 \mathrm{mg} / \mathrm{kg} /$ day of tamoxifen for 15-20 days did not alter the parasitemia curves as compared to control mock-treated groups, whereas parasitemia was undetectable in BZtreated mice (Figs 1-3). Previous experiments in leishma- niasis experimental models did not identify any differences between male and female responses to treatment with tamoxifen (Miguel et al. 2008). However, other research (de Souza et al. 2001) suggests that oestradiol may interfere in the outcome of $T$. cruzi infection in C57BL/6 female mice and, in a less pronounced way, in BALB/c and $\mathrm{C} 3 \mathrm{H}$ mice. Therefore, we decided to evaluate tamoxifen effectiveness in infected male Swiss mice (Fig. 4). No differences were detected in the response of male vs. female mice and tamoxifen treatment was completely ineffective in the control of parasitemia.

Acute $T$. cruzi infections in another mouse model were also performed. BALB/c mice infected with $T$. cruzi $\mathrm{Y}$ also developed parasitemia peaks at the 8th day post-infection. Male or female BALB/c mice treated with $20 \mathrm{mg} /$ $\mathrm{kg} /$ day tamoxifen for 15 days showed no reduction in parasitemia levels when compared to control animals. In contrast, parasitemia reached a peak in BZ-treated BALB/c mice around the 7th-8th day post-infection and became negative by the 23rd day post-infection (Fig. 5).

Another parameter assessed was the survival rate. While no mortality was detected in BZ-treated groups up to 60 days after infection (in Swiss Webster or BALB/c mice), animals treated with tamoxifen did not survive longer than control untreated groups, confirming the lack of antitrypanosomal activity of tamoxifen in these models of infection (Figs 1-5). Because there were no survivors in tamoxifen-treated and untreated groups, only the BZ-treated Swiss Webster mice were subjected to hemoculture. The cure rate was $70 \%$, as expected for the partially-resistant $T$. cruzi Y strain when infecting Swiss Webster mice.

The current chemotherapies of leishmaniasis and Chagas disease do not include drugs that are effective against both diseases. However, the novel anti-leishmanial activity of tamoxifen (Miguel et al. 2007, 2008, 2009) inspired curiosity about a possible common target between these organisms and led to the investigation of an anti-Trypanosoma effect. The results shown here indicate that tamox-

\section{TABLE}

In vitro activity of tamoxifen against

Trypanosoma cruzi strains and life stages

\begin{tabular}{lcc}
\hline Strain & Life stage & $\mathrm{EC}_{50} \pm \mathrm{SD}(\mu \mathrm{M})^{a}$ \\
\hline CL14 & Amastigote & $2.7 \pm 1.1$ \\
CL14 & Epimastigote & $17.9 \pm 3.3$ \\
$\mathrm{Y}$ & Epimastigote & $12.3 \pm 2.1$ \\
BZR & Epimastigote & $16.1 \pm 2.6$ \\
$\mathrm{Y}$ & Trypomastigote & $0.7 \pm 0.1$ \\
BZR & Trypomastigote & $0.7 \pm 0.1$ \\
\hline
\end{tabular}

$a$ : values are expressed as means \pm standard deviation (SD) of at least two independent experiments performed in triplicates. $\mathrm{EC}_{50}$ : tamoxifen effective concentration that decreases the number of viable parasites by $50 \%$ (in $24 \mathrm{~h}$ for epimastigotes and trypomastigotes and in $48 \mathrm{~h}$ for amastigotes). 
ifen is indeed active against both parasites. Data from in vitro tests, which demonstrated activity against the different $T$. cruzi life forms in the same order of magnitude as encountered for Leishmania spp, were initially very encouraging. However, despite the marked in vitro activity against two T. cruzi strains, tamoxifen did not prolong life or decrease parasitemia in experimental models of acute infection with $T$. cruzi. The therapeutic schemes in the present work included doses up to 2.5 -fold greater than the effective doses for the treatment of leishmaniasis (Miguel et al. 2008, 2009) and data presented here were obtained independently in two laboratories.

While the in vitro results indicate the shared presence of the tamoxifen biochemical target(s) in both organisms, undetermined factors prevent tamoxifen activity in vivo against $T$. cruzi. Whereas Leishmania preferentially para- sitises macrophages in the mammalian host and localizes preferentially in organs of the mononuclear phagocytic system, $T$. cruzi can inhabit most types of differentiated cells and has a wide organ distribution, especially in the acute form of the disease. Tamoxifen has been shown to accumulate in organs such as liver, bone marrow and adipose tissue, while only a minor portion of the drug remains in the serum (Lien et al. 1991). Differential tissue permeability and accumulation could explain the different outcomes of tamoxifen treatment. We cannot exclude that other factors, such as interference in immune-mediated defence mechanisms, are also of importance.

Beyond demonstrating that tamoxifen is ineffective against $T$. cruzi infections, these results also highlight the importance of using in vivo studies to validate new candidates for chemotherapy.
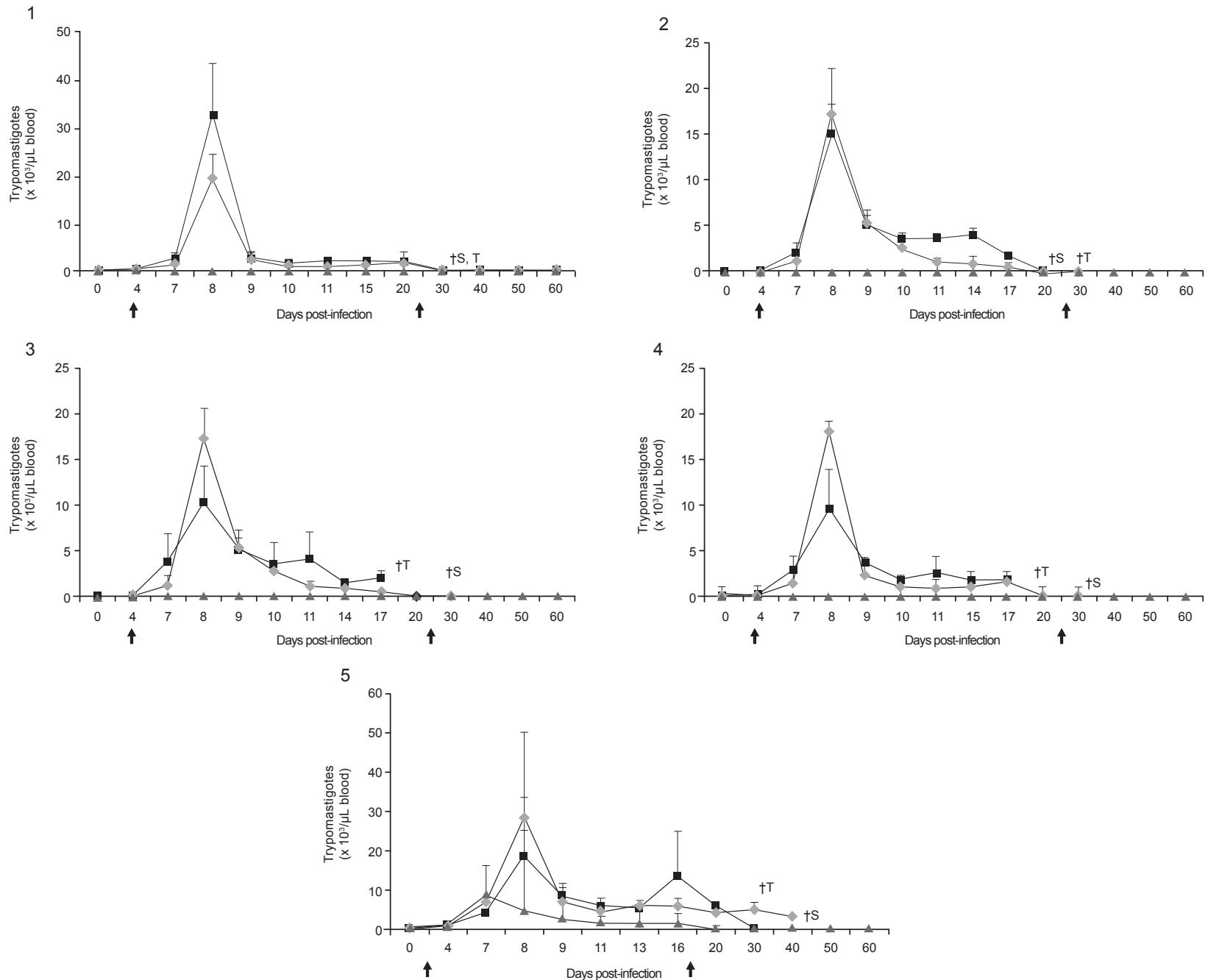

Figs 1-5: tamoxifen treatment of Trypanosoma cruzi acute infections in mice. Swiss Webster female (1-3) or male (4) mice and BALB/c female and male mice (5) were infected with $T$. cruzi Y strain. Treatment was started on the 4th day (1-4) or on the 2nd day (5) post-infection and parasitemia evaluated every other day by tail vein puncture. Animals were treated with tamoxifen (squares) at $10(1), 25(2), 50(3,4) \mathrm{or} 20 \mathrm{mg} / \mathrm{kg} / \mathrm{day}$ (5) for 15-20 days. Parasitemia curves from mock-treated animals (diamonds) and from animals that received $100 \mathrm{mg} / \mathrm{kg} / \mathrm{day}$ benznidazole (BZ) (triangles) were also obtained. Results are expressed as the mean of two independent experiments. Standard deviation is shown as a plus sided bar. The arrows indicate the period of treatment with tamoxifen or BZ. †S, †T: death of all animals from saline or tamoxifen-treated groups, respectively ( $\mathrm{n}=8-10$ animals per group). 


\section{ACKNOWLEDGEMENTS}

To Dr Ariel M Silber, for providing the CL14 Trypanosoma cruzi strain.

\section{REFERENCES}

Brener Z 1962. Therapeutic activity and criterion of cure on mice experimentally infected with Trypanosoma cruzi. Rev Inst Med Trop Sao Paulo 4: 389-396.

Brener Z, Chiari E 1963. Morphological variations observed in different strains of Trypanosoma cruzi. Rev Inst Med Trop Sao Paulo 5: 220-224.

Camargo EP 1964. Growth and differentiation in Trypanosoma cruzi. I. Origin of metacyclic trypanosomes in liquid media. Rev Inst Med Trop Sao Paulo 6: 93-100.

de Souza EM, Rivera MT, Araújo-Jorge TC, de Castro SL 2001. Modulation induced by estradiol in the acute phase of Trypanosoma cruzi infection in mice. Parasitol Res 87: 513-520.

El-Sayed NM, Myler PJ, Blandin G, Berriman M, Crabtree J, Aggarwal G, Caler E, Renauld H, Worthey EA, Hertz-Fowler C, Ghedin E, Peacock C, Bartholomeu DC, Haas BJ, Tran AN, Wortman JR, Alsmark UC, Angiuoli S, Anupama A, Badger J, Bringaud F, Cadag E, Carlton JM, Cerqueira GC, Creasy T, Delcher AL, Djikeng A, Embley TM, Hauser C, Ivens AC, Kummerfeld SK, Pereira-Leal JB, Nilsson D, Peterson J, Salzberg SL, Shallom J, Silva JC, Sundaram J, Westenberger S, White O, Melville SE, Donelson JE, Andersson B, Stuart KD, Hall N 2005. Comparative genomics of trypanosomatid parasitic protozoa. Science 309: 404-409.

Filardi LS, Brener Z 1987. Susceptibility and natural resistance of Trypanosoma cruzi strains to drugs used clinically in Chagas disease. Trans R Soc Trop Med Hyg 81: 755-759.

Jordan VC 2003. Tamoxifen: a most unlikely pioneering medicine. Nat Rev Drug Discov 2: 205-213.

Landfear SM 2008. Drugs and transporters in kinetoplastid protozoa. Adv Exp Med Biol 625: 22-32.

Lien EA, Solheim E, Ueland PM 1991. Distribution of tamoxifen and its metabolites in rat and human tissues during steady-state treatment. Cancer Res 51: 4837-4844.
Marin-Neto JA, Rassi A Jr, Avezum A Jr, Mattos AC, Rassi A, Morillo CA, Sosa-Estani S, Yusuf S, BENEFIT Investigators 2009. The BENEFIT trial: testing the hypothesis that trypanocidal therapy is beneficial for patients with chronic Chagas heart disease. Mem Inst Oswaldo Cruz 104 (Suppl. I): 319-324.

Michels PA, Bringaud F, Herman M, Hannaert V 2006. Metabolic functions of glycosomes in trypanosomatids. Biochim Biophys Acta 1763: 1463-1477.

Miguel DC, Yokoyama-Yasunaka JK, Andreoli WK, Mortara RA, Uliana SR 2007. Tamoxifen is effective against Leishmania and induces a rapid alkalinization of parasitophorous vacuoles harbouring Leishmania (Leishmania) amazonensis amastigotes. J Antimicrob Chemother 60: 526-534.

Miguel DC, Yokoyama-Yasunaka JK, Uliana SR 2008. Tamoxifen is effective in the treatment of Leishmania amazonensis infections in mice. PLoS Negl Trop Dis 2: e249.

Miguel DC, Zauli-Nascimento RC, Yokoyama-Yasunaka JK, Katz S, Barbiéri CL, Uliana SR 2009. Tamoxifen as a potential antileishmanial agent: efficacy in the treatment of Leishmania braziliensis and Leishmania chagasi infections. $J$ Antimicrob Chemother 63: 365-368.

Murta SM, Romanha AJ 1998. In vivo selection of a population of Trypanosoma cruzi and clones resistant to benznidazole. Parasitology 116: 165-171.

Pérez-Molina JA, Pérez-Ayala A, Moreno S, Fernández-González MC, Zamora J, López-Velez R 2009. Use of benznidazole to treat chronic Chagas' disease: a systematic review with a meta-analysis. J Antimicrob Chemother 64: 1139-1147.

Santos SL 2008. Análise proteômica da forma tripomastigota de uma população de Trypanosoma cruzi susceptivel e outra resistente ao benzonidazol, MSc Thesis, Instituto de Pesquisas René Rachou, Belo Horizonte, 72 pp.

Schofield CJ, Jannin J, Salvatella R 2006. The future of Chagas disease control. Trends Parasitol 22: 583-588.

Silva LHP, Nussenzweig V 1953. Sobre uma cepa de Trypanosoma cruzi altamente virulenta para o camundongo branco. Folia Clin Biol 20: 191-207.

Stuart K, Brun R, Croft S, Fairlamb A, Gürtler RE, McKerrow J, Reed S, Tarleton R 2008. Kinetoplastids: related protozoan pathogens, different diseases. J Clin Invest 118: 1301-1310. 